Portland State University

PDXScholar

Summer 2010

\title{
Climate Change, Its Effect on Migration Patterns of the Cackling Goose and White-Fronted Goose in the Willamette Valley, and Implications for Goose Management
}

Kelly Warren

Portland State University

Follow this and additional works at: https://pdxscholar.library.pdx.edu/mem_gradprojects

Part of the Environmental Indicators and Impact Assessment Commons, and the Natural Resources and Conservation Commons Let us know how access to this document benefits you.

\section{Recommended Citation}

Warren, Kelly, "Climate Change, Its Effect on Migration Patterns of the Cackling Goose and White-Fronted Goose in the Willamette Valley, and Implications for Goose Management" (2010). Environmental Science and Management Professional Master's Project Reports. 16.

https://pdxscholar.library.pdx.edu/mem_gradprojects/16

https://doi.org/10.15760/mem.22

This Project is brought to you for free and open access. It has been accepted for inclusion in Environmental Science and Management Professional Master's Project Reports by an authorized administrator of PDXScholar. Please contact us if we can make this document more accessible: pdxscholar@pdx.edu. 
Climate Change, Its Effect on Migration Patterns of the Cackling Goose and White-Fronted Goose in the Willamette Valley, and Implications for Goose Management

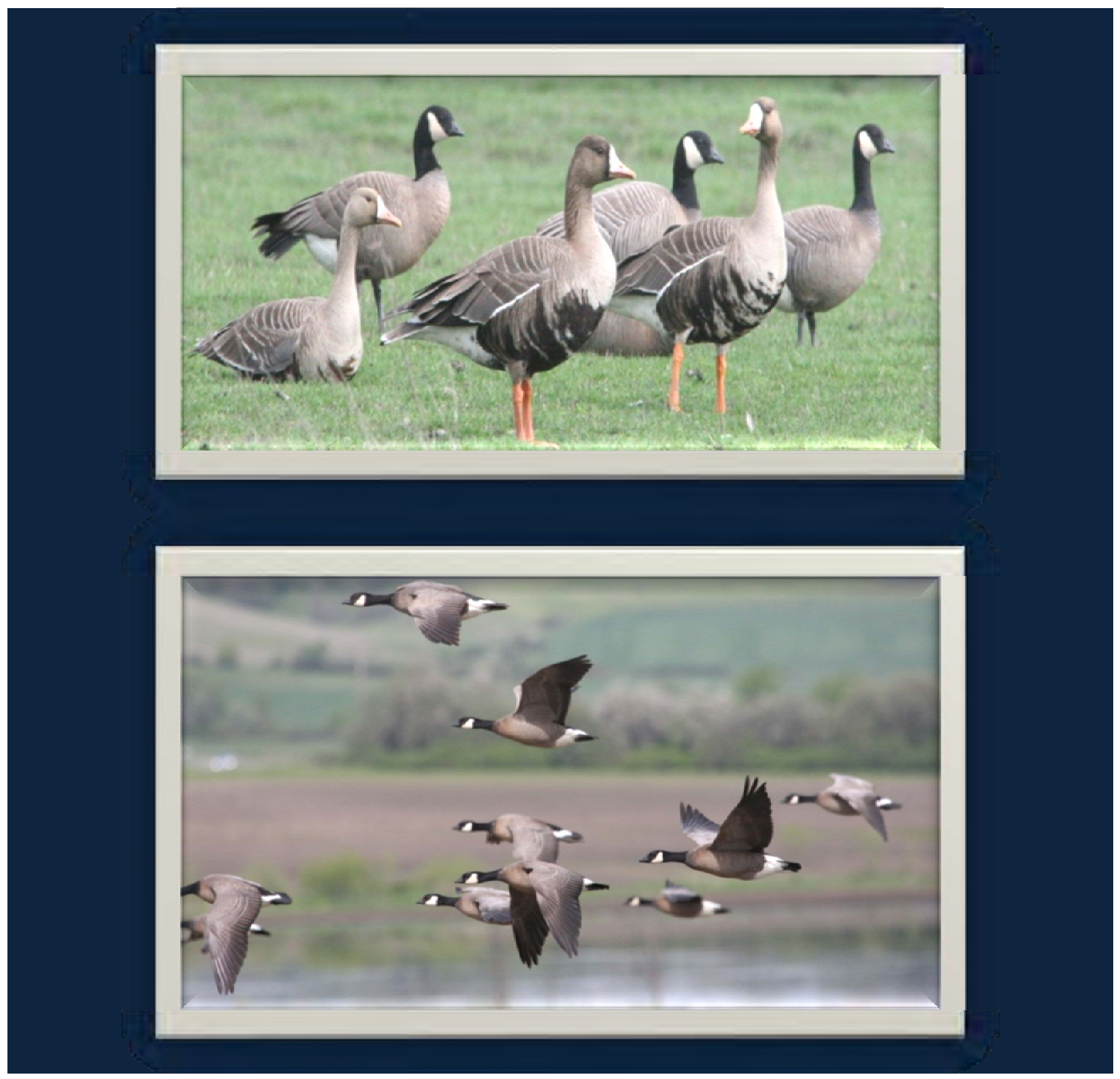

\section{By Kelly Warren}

\section{Prepared for}

The Pacific Flyway Council

September 1, 2010 


\section{Table of Contents}

1. Introduction

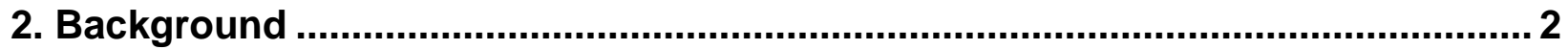

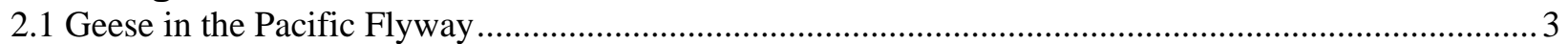

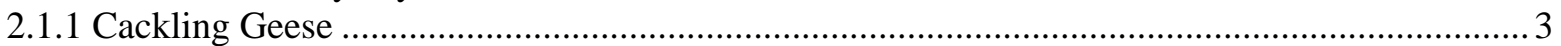

Migration and Breeding Areas .............................................................................................. 3

Wintering Areas ...........................................................................................................

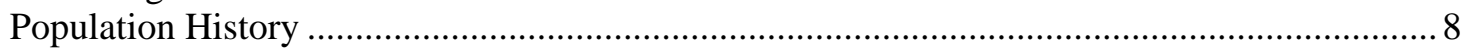

2.1.2 Pacific White-Fronted Geese .........................................................................................

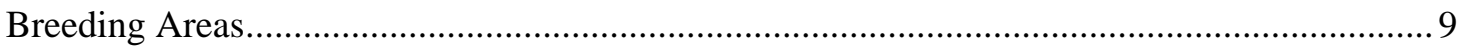

Migration and Wintering Areas ....................................................................................... 9

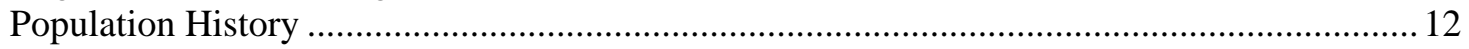

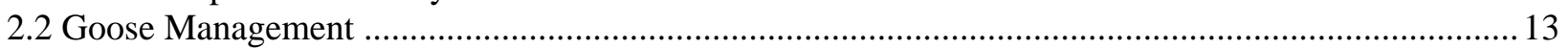

2.2.1 Pacific Flyway Council..................................................................................................... 13

2.2.2 Management of Cackling Geese and White-Fronted Geese ....................................................... 15

Cackler Management …………………………………………………………………….... 15

Management of White-Fronted Geese …………………………………………………….... 16

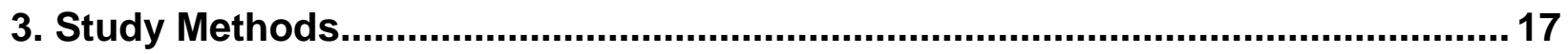

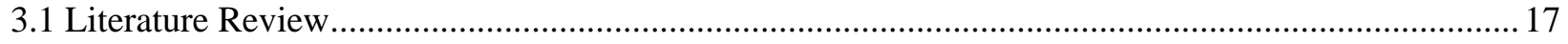

3.1.1 Historical Breeding and Wintering Surveys ............................................................................ 17

3.1.2 Historical Breeding Ground Information ............................................................................... 17

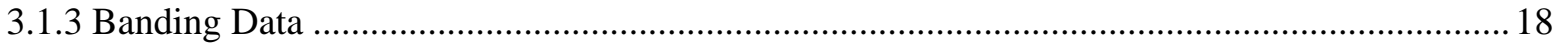

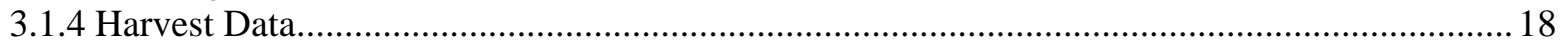

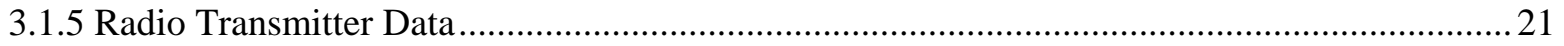

3.1.6 Interpretation Aerial and Still Photographs............................................................................ 21

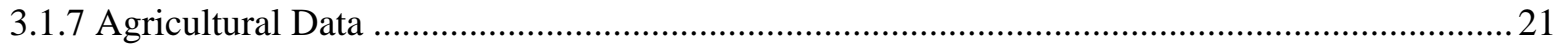

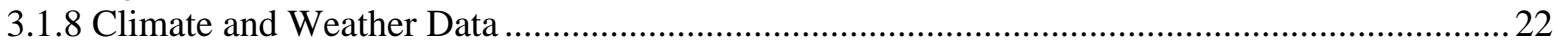

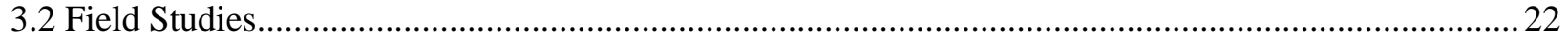

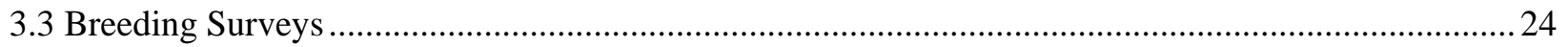

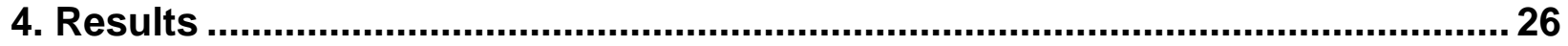

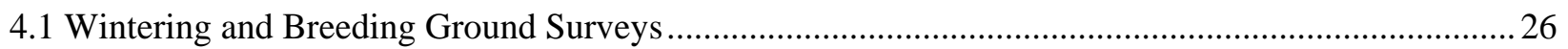

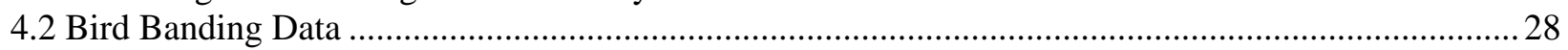

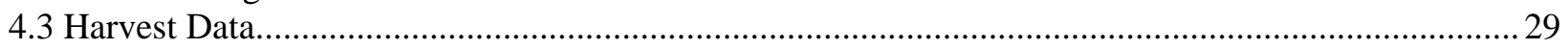

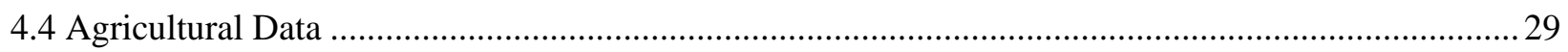

4.5 Weather and Climate Data ................................................................................................................ 31

4.6 Interpretation of Aerial Photographs.................................................................................................. 33

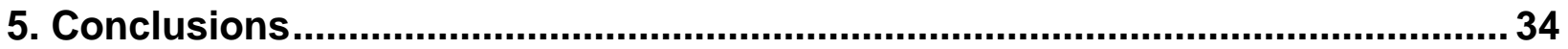

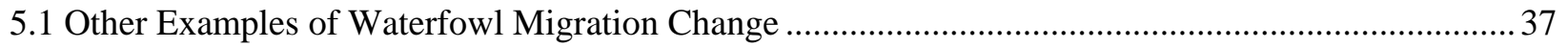

5.1.1 Black Brant ……………………………………………………………………………..... 37

5.1.2 Northern Pintail...…………………………………………………………………………... 37

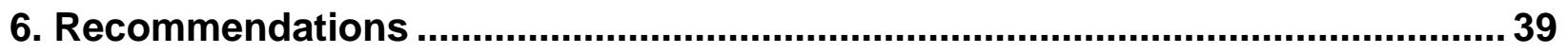

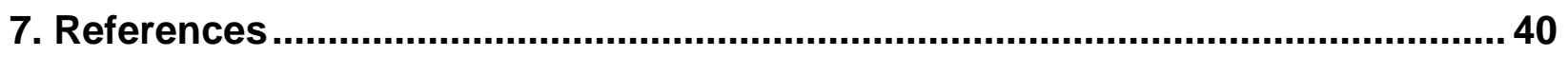




\section{Appendices}

\section{Appendix A - Forms}

A1. Breeding Ground Nest Cards

A2. Wintering Ground Survey Sheet

A3. Band Data Request Form

Appendix B - Harvest Data

Washington Permit Zone Harvest Data

\section{Appendix C - Temperature Data}

C1. Average Temperature Data for Willamette Valley by Month 1980-Present

C2. Average Temperature in the Willamette Valley and Southwest Washington 1971-2010

C3. Top 5 Warmest and Coldest Months, Years, and Seasons in Portland, Oregon

C4. Portland Airport, Oregon: Normals, Means and Extremes

C5. California State Mean Temperature, 1900-2005

C6. Redding, California: Normals, Means and Extremes

\section{List of Tables}

1. Permit Zone Harvest Data for Cacklers and White-Fronts, 1985-2009 ............................................ 35

2. Average Winter Temperature in Oregon and California 1986-2010 ................................................ 52

3. Three-Month-Average Snowpacks in El Niño vs. La Niña Years ....................................................... 54

\section{List of Figures}

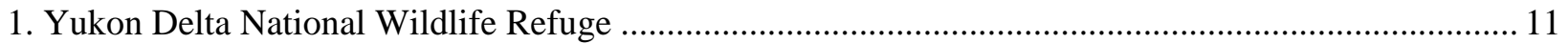

2. Important Fall Staging Areas for Cackling Canada Geese …............................................................... 12

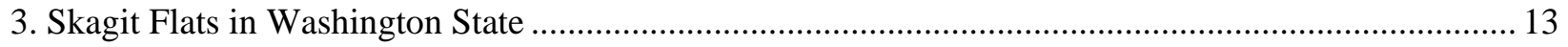

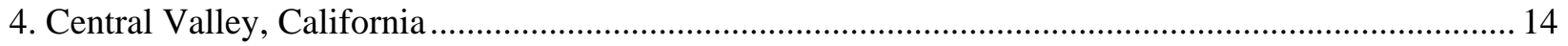

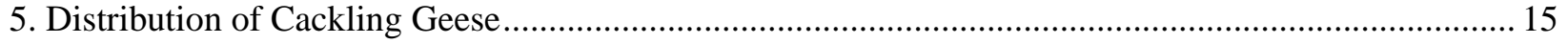

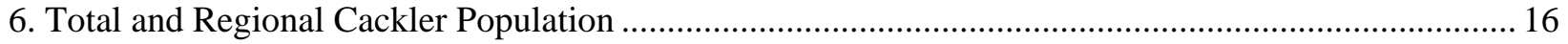

7. Important Staging and Wintering Areas for White-Fronted Geese....................................................... 19

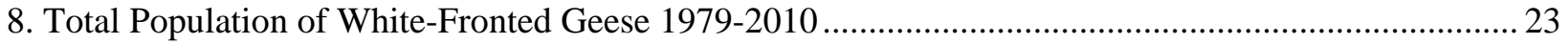

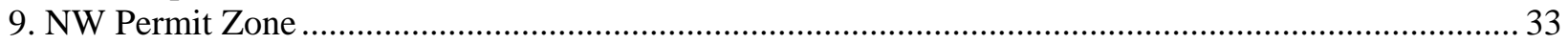

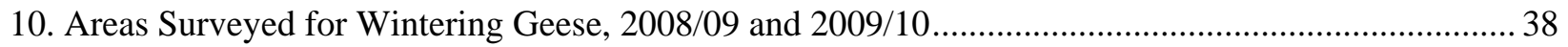

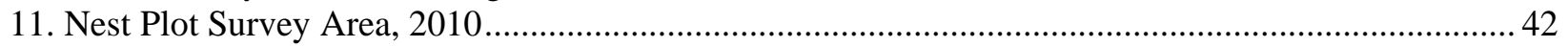

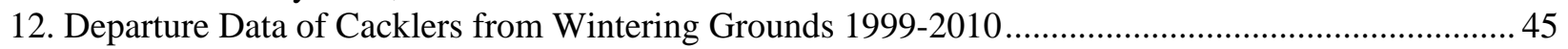

13. September Sightings of Cacklers in the Willamette Valley, 1999-2010............................................ 46

14. Number of Cackler Band Returns in Washington State, 1995-2010 ............................................... 47

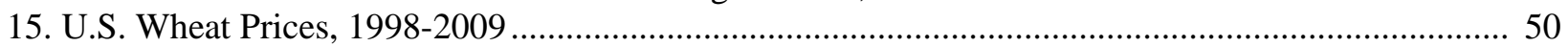

16. Average Temperature in the Northwest, Observed and Modeled................................................... 54 


\section{Acknowledgments}

I would like to thank my committee: Mark Sytsma, Joe Maser, and Julian Fischer. Each has gone beyond in assisting me on my project. Thank you for all your guidance, advice, and support. Special thanks go to staff of U.S. Fish and Wildlife Service (USFWS) Regions 4 and Region 7, who welcomed me and challenged me to make this project reach its full potential.

Thank you to my family for introducing me to the outdoors and supporting my passion to learn as much as possible about its splendor. Thanks go to Julia who graciously put up with my absence during my surveys and Alaska trips. These people supported me throughout this project in numerous ways including reading drafts, asking questions, and offering constructive comments. I am grateful to you all for your generous support.

This thesis is dedicated to my grandfather, Charles E. Warren, who made me the person I am today and inspired my passion for waterfowl.

Thank you also to my community partner who played a significant role in the formation of this document: USFWS Regions 7 and 4 provided the opportunity to participate in breeding ground and wintering ground surveys. This experience allowed me to see first-hand the habitat changes taking place on the Yukon Delta National Wildlife Refuge and the Willamette Valley. I was also able to gather data specific to the subject of this thesis. USFWS personnel also were generous with their time in answering my many questions and provided me with much of the important data that formed the basis for the results and conclusions contained in this thesis. This project could not have been accomplished without the assistance and support of the USFWS personnel. 


\section{Abstract}

This thesis considers the question of whether climate change is affecting the migration patterns of geese in the Pacific Flyway, specifically cackling geese (Branta hutchinsii minima) and Pacific white-fronted geese (Anser albifrons frontalis). Ancillary questions that are considered are as follows:

- If global warming is affecting these species, what is the nature of the effects?

- How are the changes affecting the human environment and what can be done about these effects?

In 1994, the majority of the cackler population in the Pacific Flyway began to winter in Oregon's Willamette Valley rather than in their historical wintering areas in California's Central Valley. In recent years, the Pacific white-fronted goose has shown a change in behavior similar to that of cacklers just before their major shift. The reasons for this shift have not been clear, though climate change, agricultural shifts, or competition with other species were thought to be possible causes.

Analyses of historical breeding and wintering surveys, bird band data, harvest data, agricultural data, and climate and weather data were undertaken in the course of this thesis to see if the cause or causes could be identified. The results showed that climate and weather data, i.e. an increase in average annual temperature coupled with occasional severe winters, most closely correlated with the cacklers' shift northward. The data comparison revealed that there is a direct relationship between cacklers and a warming shift seen on the wintering grounds. There also was a secondary correlation between the northward shift and recent changes in agricultural crops in the Willamette Valley. Substantially less data are available for white-fronts, and the relationship between their recent migration changes and climate and/or other factors is much less clear.

The following recommendations for management and further study are aimed at more completely understanding the scope and causes of migration shifts and formulating well-founded management plans for geese in the Pacific Flyway:

- Continue research to determine if climate change is causing changes in goose population numbers and behavior.

- Expand breeding ground flight surveys to include cacklers and habitat preference to learn how habitat change on the Y-K Delta is altering cackler behavior and breeding success.

- Expand radio transmitter studies and collar programs for cacklers in Oregon and Washington to verify northerly wintering shifts.

- Expand collar programs for cacklers wintering in the Willamette Valley to determine if the population is continuing to shift northward.

- Expand banding programs for white-fronted geese to gather more data about migration patterns.

- Develop models that will allow researchers and managers to correlate migration behavior with various environmental factors including climate change in order to: 1) determine which factors are causing migration changes in specific waterfowl populations and 2) allow managers to make changes to management plans in advance of rapid changes. 
- Inform the public about how it can assist in collar surveys or volunteer for the U.S. Fish and Wildlife Service (USFWS). This will enable USFWS to have more concrete data and give the public an opportunity gain a greater understanding of geese and goose management.

- Expand research on urban cackling geese to determine the nature and scope of their effect on the human environment and to devise management strategies.

- Research energetics in migrating geese to determine whether the shift in migration patterns has its basis in climate change.

- Increase data exchange and coordination among agencies.

- Formulate and implement plans at the city and county levels to manage growing numbers of geese in urban areas.

- Recognize and anticipate the possibility that goose populations may move into new wintering areas and formulate plans for management of those species.

- Implement low cost techniques, such as more liberal bag limits and seasons, hazing, etc., to assist agricultural landowners in decreasing goose-related crop damage. 


\section{INTRODUCTION}

Until recently, very few geese used western Oregon and southwest Washington for wintering. California was the primary wintering ground for goose subspecies such as cackling geese (Branta hutchinsii minima), white-fronted geese (Anser albifrons frontalis), Taverner's geese (Branta hutchinsii taverni) and lesser Canada geese (Branta canadensis parvipes). Within the last 25 years, geese have been rapidly shifting from traditional wintering areas in California to western Oregon and southwest Washington (Warren 2007). Increased winter temperatures may be a major contributor to this change. Over the last 20 years, average fall and winter temperatures have increased $1.89^{\circ} \mathrm{F}$ in the Willamette Valley (Flowers 2010). This phenomenon has had, and is expected to continue to have, a significant impact on goose behavior and, consequently, management of goose populations in the Willamette Valley.

This thesis considers the question of whether climate change is affecting the migration patterns of geese in the Pacific Flyway, specifically cackling geese (cacklers) and Pacific white-fronted geese (whitefronts). Ancillary questions that are considered are as follows:

- If global warming is having an effect on these species, what is the nature of the effects?

- How are the changes affecting the human environment and what can be done about these effects?

Indications are that these goose species have altered their migration timing and wintering areas in recent years. The changes are presenting challenges to waterfowl managers, farmers, and hunters.

Background information containing pertinent information about goose behavior, migration routes, wintering areas, habitat, behavior, and management is presented in Section 2. Section 3 describes the methods employed in the study. Data was obtained from both existing literature and original data collection. In Section 4, the results of the data collection are presented. Sections 5 and 6 contain a discussion of the information obtained, conclusions, and recommendations. A reference list appears in Section 7. 


\section{BACKGROUND}

Anthropological data have shown that the Willamette Valley has been an important wintering area for geese since the end of the last Ice Age nearly 15,000 years ago (Pacific Flyway Council 1999a). Bellrose (1981) indicates that the wintering population and numbers appeared to be quite stable. The main species wintering in the valley was the dusky Canada goose; an average of approximately 19,000 duskies overwintered annually in the Willamette Valley (Pacific Flyway Council 2008a). Remnants of geese found by archeologists as well as fossil records indicate that only the dusky wintered in the Willamette Valley in the past; there is no evidence that cacklers or other subspecies of Canada goose wintered in the valley. However, beginning in the 1980s, greater numbers of cacklers began to show up in the Willamette Valley as that species shifted northward from traditional wintering grounds in California. This shift has continued at a rapid pace until, today, nearly 90 percent of the geese that overwinter in the Willamette Valley are cacklers.

In addition to the cacklers, four other goose subspecies appear to have shifted, or to be in the process of shifting, their traditional wintering grounds to the Willamette Valley and the Oregon coast. These four subspecies are Taverner's, Aleutian (Branta hutchinsii leucopariea), Lesser, and Western (Branta canadensis moffitti). White-fronted geese are beginning to exhibit the same signs exhibited in the 1980s by cacklers prior to their shift.

This thesis focuses on the cackling goose and the Pacific white-fronted goose. These species were chosen because they make up the majority of the goose populations within the Pacific Flyway. If these species begin to winter farther north, the natural and human environments and goose management in the Pacific Flyway will be greatly affected.

The reasons for the changes have not been precisely determined, but it is hypothesized that climate change is a major contributor. For example, surveys on the Yukon-Kuskokwim Delta (Y-K Delta) in western Alaska have shown that river channels that used to be around 10 feet wide have grown to nearly 50 feet in width due to increased erosion. Erosion of river channels was, until recently, kept in check by the underlying layers of permafrost on the Delta. However, average summer temperatures have risen in Alaska, which has resulted in melting of exposed permafrost. This has caused river channels to widen and has shortened the length of time water is held in potholes in the Delta's wetlands. In turn, the nesting success of waterfowl species that are more dependent on a large quantity of water has been adversely affected. Birds that nest in upland areas, however, appear to be more successful (C. Dau, USFWS, personal communication, June 2009).

Within the past 15 years, the number of geese wintering in the Willamette Valley has increased from about 100,000 to about 400,000 (Pacific Flyway Council 2009). The shift of wintering goose populations into western Oregon has posed a number of management problems for the U.S. Fish and Wildlife Service (USFWS) and the Oregon Department of Fish and Wildlife (ODFW). The geese feed upon Willamette Valley grain and grass fields, which are an important component of Oregon's agricultural economy. Larger numbers of geese mean greater depredation of the fields and requests by farmers for help controlling the damage. 


\subsection{GEESE IN THE PACIFIC FLYWAY}

\subsubsection{Cackling Geese}

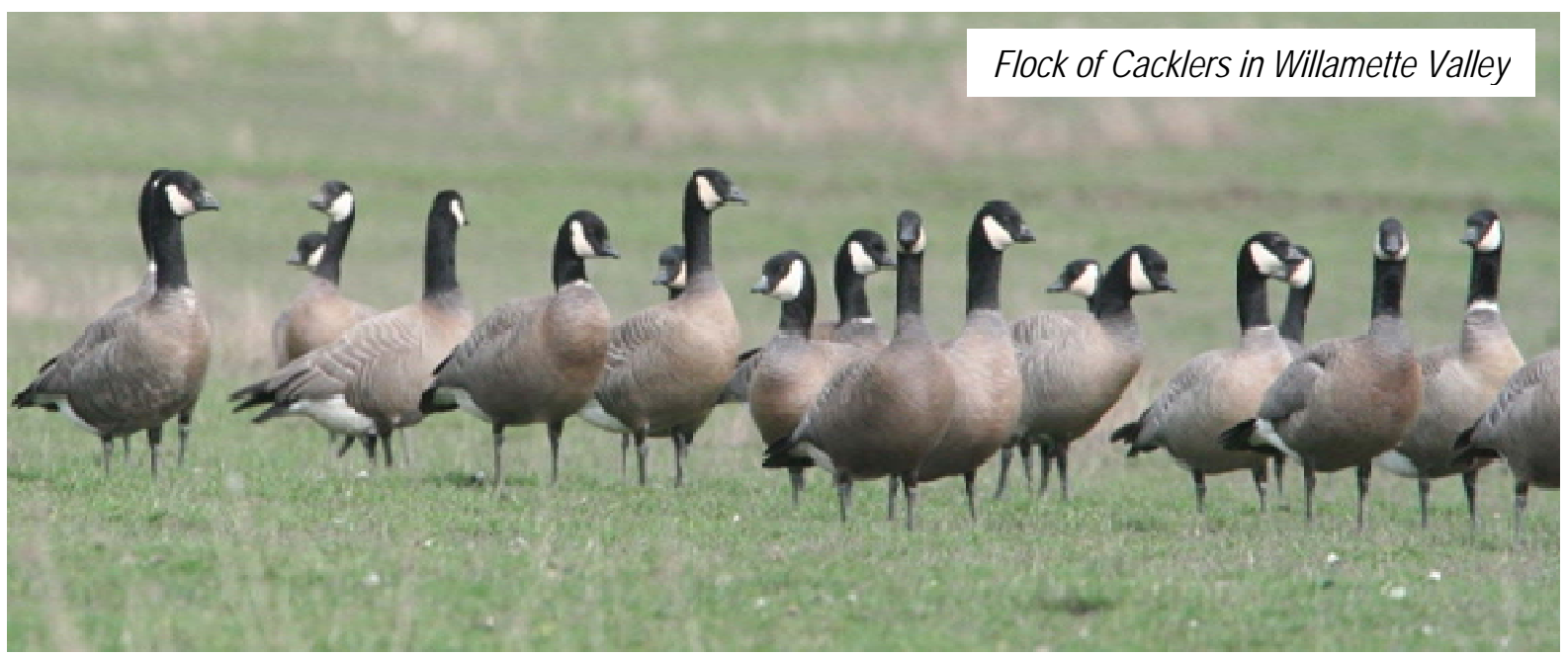

\section{Migration and Breeding Areas}

Cackling geese migrate north in the spring to the Y-K Delta (Figure 1), stopping in the intertidal marshes of Cook Inlet to rest and increase energy reserves for breeding. They also use the pastures and other agricultural lands near Palmer, Alaska. Nearly all of the primary spring habitats in Cook Inlet are within protected state wildlife refuges. Cacklers are an important subsistence harvest species for Alaska Natives.

Nesting occurs in the extensive pond and meadow mosaic habitats of the outer Y-K Delta (Mickelson 1975; Ely et al. 1996). Most nests are established on small islands in pothole ponds; nest densities are somewhat "clumped." Cacklers also make extensive use of wet tundra and river/slough bank meadows of Carex sp. and other wetland vegetation (Babcock and Ely 1994).

Cacklers nest somewhat earlier than other goose species. Placement of nests on the small islands allows them to escape from terrestrial predators and to distance themselves from the nests of more aggressive goose species and subspecies. Cacklers also remain fairly close to water during the nesting season; they are rarely found more than 30 yards from water and, if threatened, will go to the water to escape the threat.

Cacklers leave the breeding grounds in mid-October. Migration appears to coincide with the onset of fall storms and associated strong northwest winds in western Alaska (Gill et al. 1997). The intertidal marshes and coastal wetlands, particularly Ugashik Bay on the north side of the Alaska Peninsula, are vital fall staging habitats (Figure 2). Cacklers use these areas, grazing on pond shorelines, to build up body mass for the southward migration. Roosting occurs mostly on exposed intertidal bars (Gill, Bollinger, and Petersen 1986; Sedinger and Bollinger 1987). Most of the primary use areas in Ugashik Bay are in protected status as are portions of cackler habitat within the Cinder River Critical Habitat Area. 


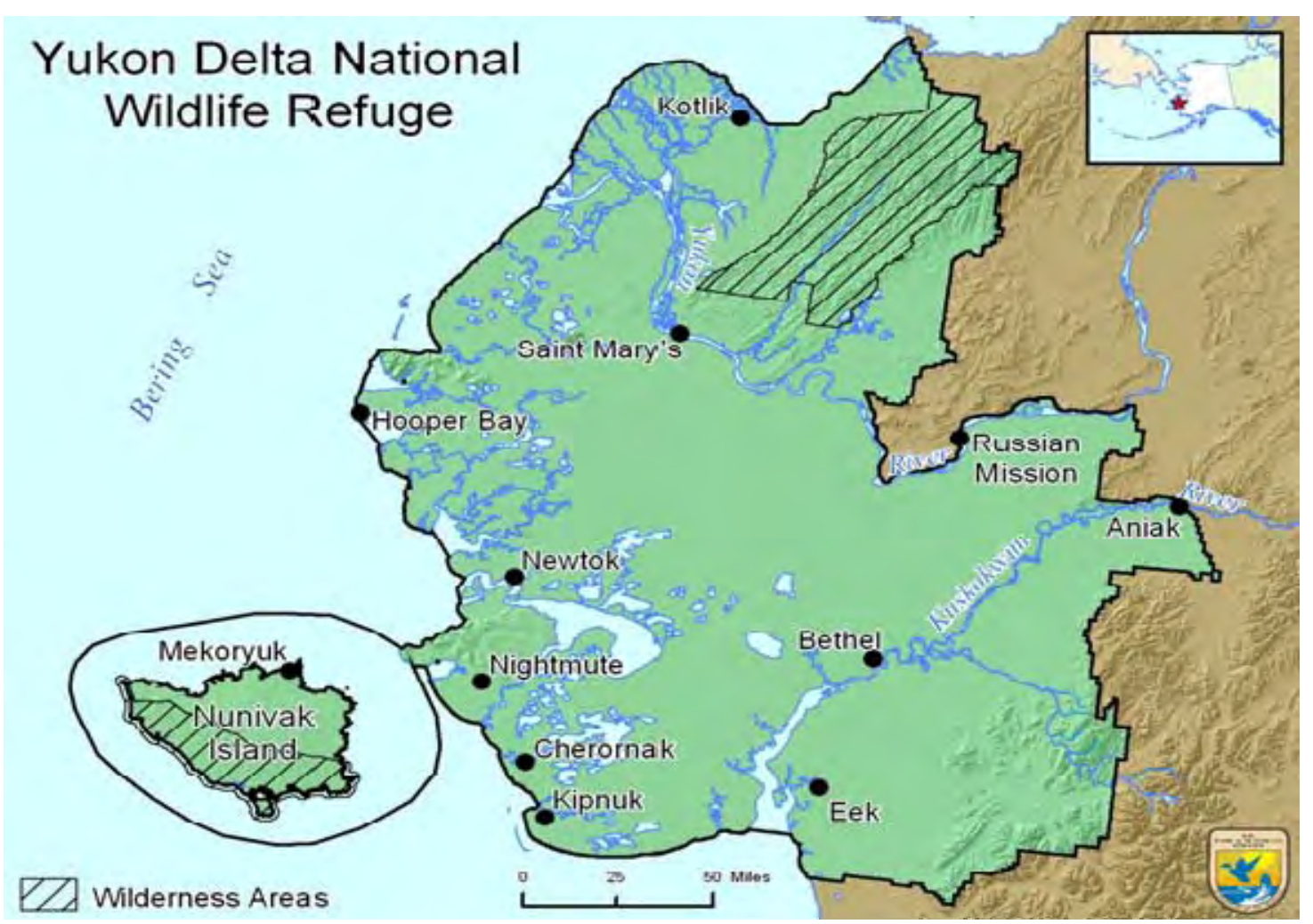

Figure 1: Yukon Delta National Wildlife Refuge (USFWS 2003)

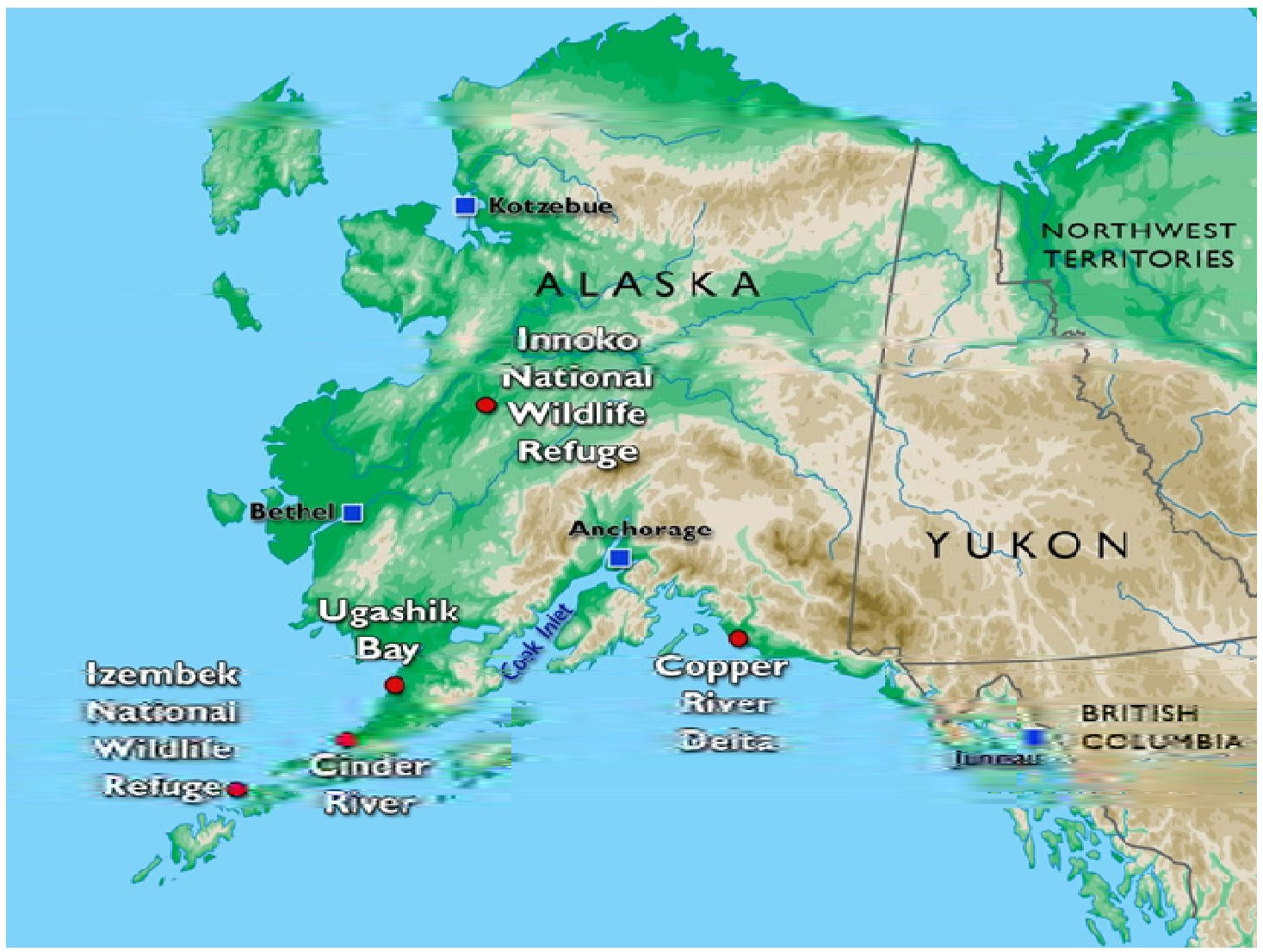

Figure 2: Important Fall Staging Areas in Alaska for Cackling Canada Geese (Pacific Flyway 2003) 
In some years, e.g. 1987, large portions of the population may bypass traditional Alaskan staging grounds and fly directly to wintering grounds (Gill et al. 1997). It appears that cacklers can fly non-stop from the Alaska Peninsula to the lower Columbia River. ${ }^{1}$ Occasionally, cacklers are sighted in northern Puget Sound (primarily Skagit Flats (Figure 3)), the northern Olympic Peninsula, and eastern Washington during fall migration.

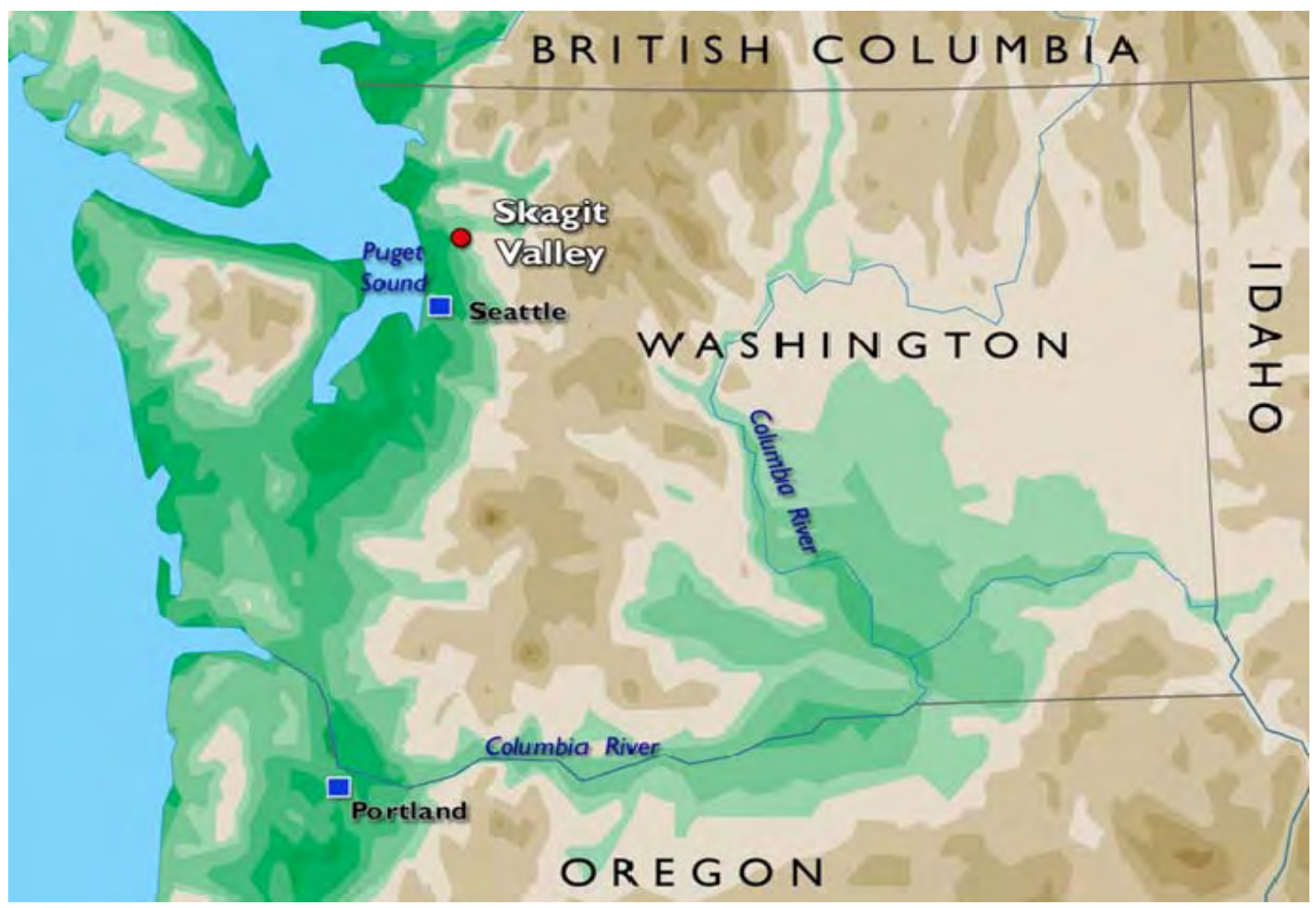

Figure 3: Skagit Flats in Washington State

The geese generally begin to arrive in southwest Washington and northwest Oregon in mid- to late October, with the peak of the population arriving between October 25 and November 7. In some years, the population arrives early. In 2009, for example, a majority of cacklers were recorded in late September. Cacklers are an important species for sport hunters in Washington and Oregon.

\section{Wintering Areas}

Historically, most cackling geese wintered in central California (Figure 4) (Nelson and Hansen 1959; King and Lensink 1971; Raveling 1984). Banding and marking studies were conducted between 1982 and 1984 on the Y-K Delta and in northern California. Subsequent observations of these geese in 1984 and 1985 illustrated the typical winter distribution prior to the population increase and geographic shifts of the 1990s.

\footnotetext{
${ }^{1}$ Gill et al. (1997) documented 11 marked birds that departed the Alaska Peninsula and arrived in the Klamath Basin within 48 to 72 hours.
} 


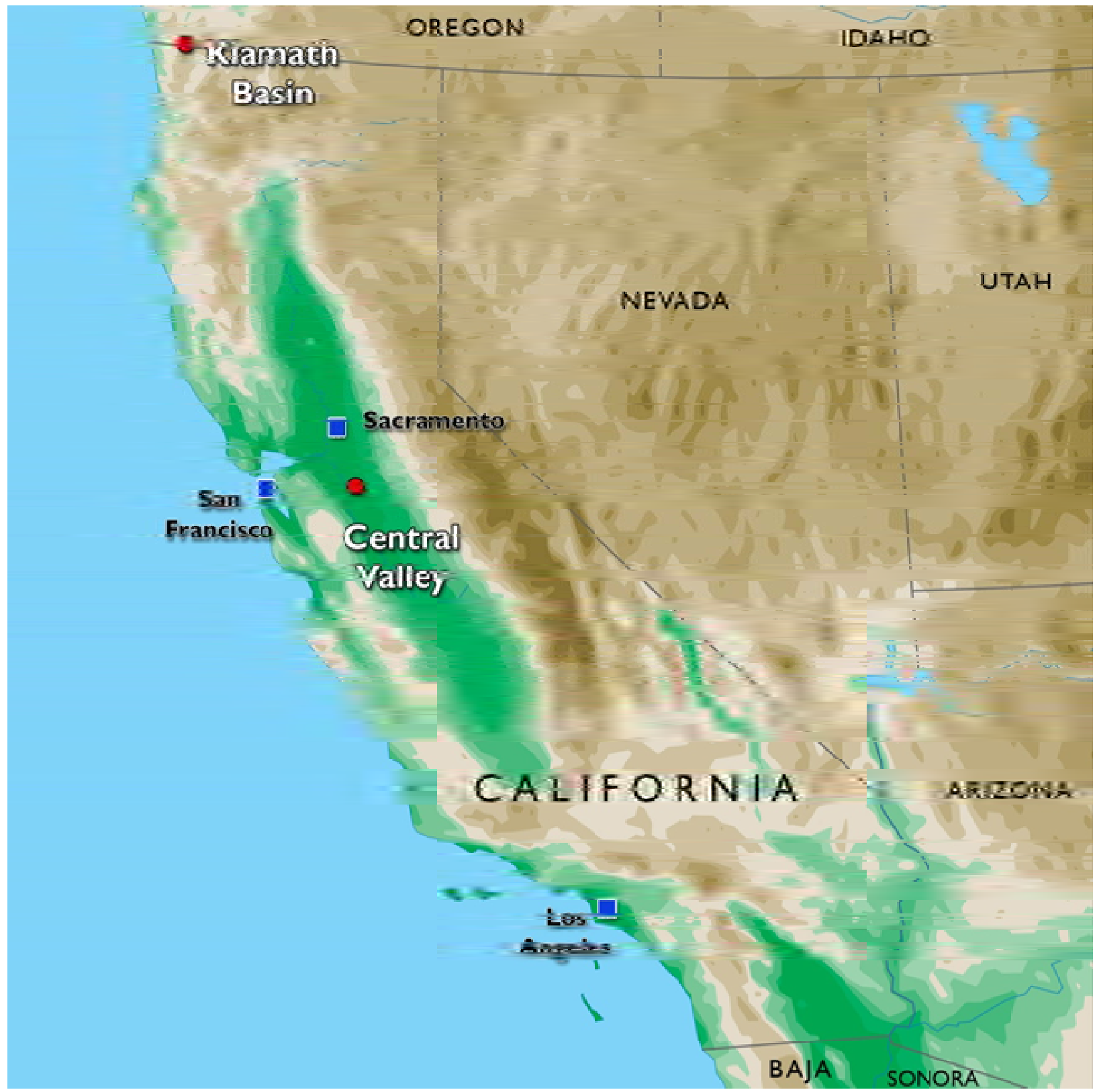

Figure 4: Central Valley, California

The winter distribution of Cackling geese has shifted markedly northward in recent years. Since 1985, all banding and marking has occurred on the Y-K Delta and none has been done in California. Nonetheless, banding data (Section 3.1.3) illustrate the dramatic change in winter distribution in the 1990s. During the 10-year period between 1988 and 1997, observations of marked cackling geese in southern Oregon and California dropped to very low levels. Concurrently, the number of geese observed in the Willamette Valley to Lower Columbia River region of Washington and Oregon has increased greatly (Figure 5). 


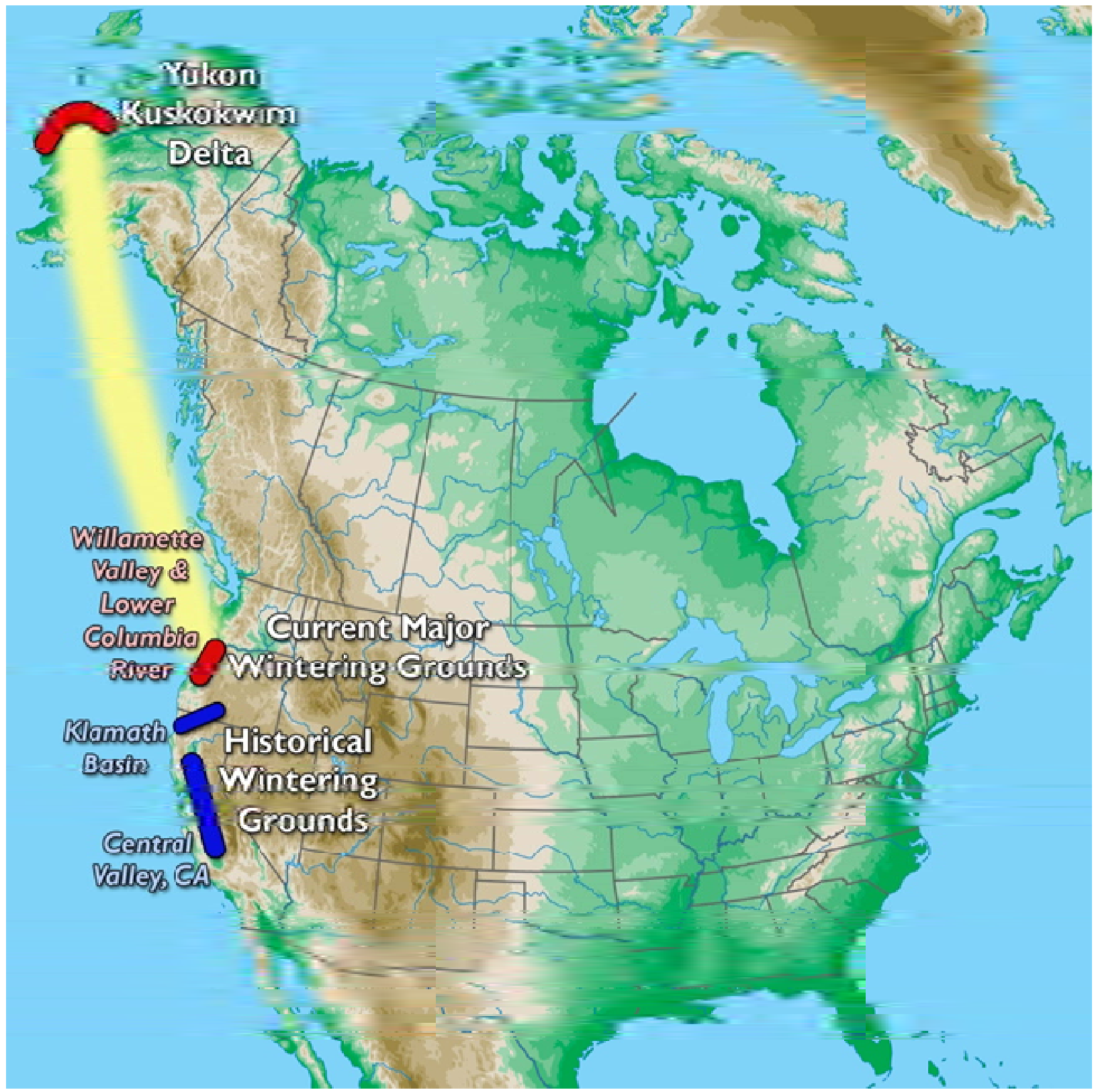

Figure 5: Distribution of Cackling Geese (Warren 2007)

This shift coincided with drought conditions in California between 1986 and 1992, which may have affected winter habitat quality and, consequently, use by cacklers. The average winter temperature in the Willamette Valley was also nearly four degrees higher in the mid-1990s than 50 years ago (Flowers 2010). Since 1993, the majority of cackling geese have wintered in Oregon and Washington. Starting in 2006, cacklers have been seen in areas of southern British Columbia as late as December. In the fall of 2008 and 2009, cacklers established a small wintering population in southern British Columbia (J. Fischer, USFWS, personal communication, February 2010). 


\section{Population History}

The cackler population numbered around 400,000 birds in the late 1960s, but dropped to around 20,000 in the mid-1980s. This decline was thought to be due to a combination of effects from subsistence harvest in Alaska and sport harvest on the wintering grounds, especially in California (Pacific Flyway Council 2008). However, it is now known that the decline was likely a combination of low population numbers and a geographic shift in wintering. The geese formerly were found primarily in the Klamath Basin and Central Valley during the winter where they were routinely counted in wintering ground surveys. They were not specifically included in Willamette Valley counts, so were not recorded until the shift northward became more apparent (B. Bales, ODFW, personal communication, December 2009). Populations rebounded following harvest restrictions implemented in 1979 and concerted flyway-wide restoration efforts that started in 1983 (Pamplin 1986). Figure 6 shows the 20-year decrease in cackler numbers on their staging grounds in Central Valley and the Klamath Basin due to their shift to the Willamette Valley.

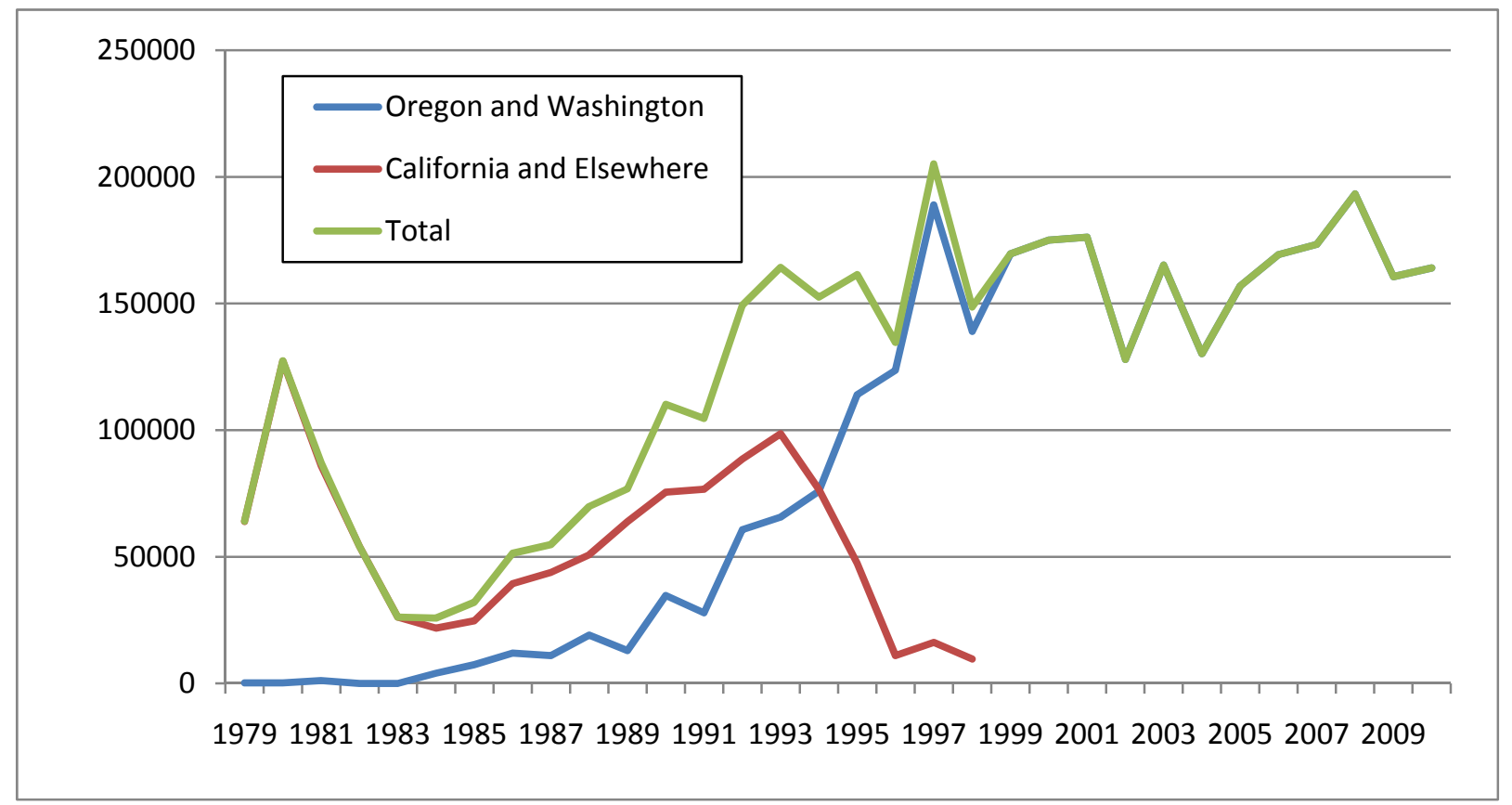

Figure 6: Total and Regional Cackler Population (Pacific Flyway Council 2010)

Prior to the 1990s, the cackler was an infrequent resident in the Willamette Valley and lower Columbia River, spending staging in the Klamath Basin and wintering in California's Central Valley (Figures 4 and 5). Now, 95 percent of the cackler population winters in Oregon. The shift to wintering grounds in Oregon coincided with a population rebound; by 1997, there were about 200,000 geese wintering in the Willamette Valley and lower Columbia River (Pacific Flyway Council 1999). Since then, the number has fluctuated, but has remained between 150,000 and 200,000 birds. The overall trend currently is for continued increases in the cackler population.

The 2010 estimate projected by USFWS is 188,000 . The three-year average estimate is 180,000 , which is the highest three-year trend in many decades (B. Reishus, ODFW, personal communication, July 2010). However, the population has fluctuated over the past five years, making it difficult to identify a long-term population trend. The population is still below management objectives and, therefore, is being carefully managed in order to eventually meet the management objective set by the Pacific Flyway Council (Section 2.2.1). 


\subsubsection{Pacific White-Fronted Geese}

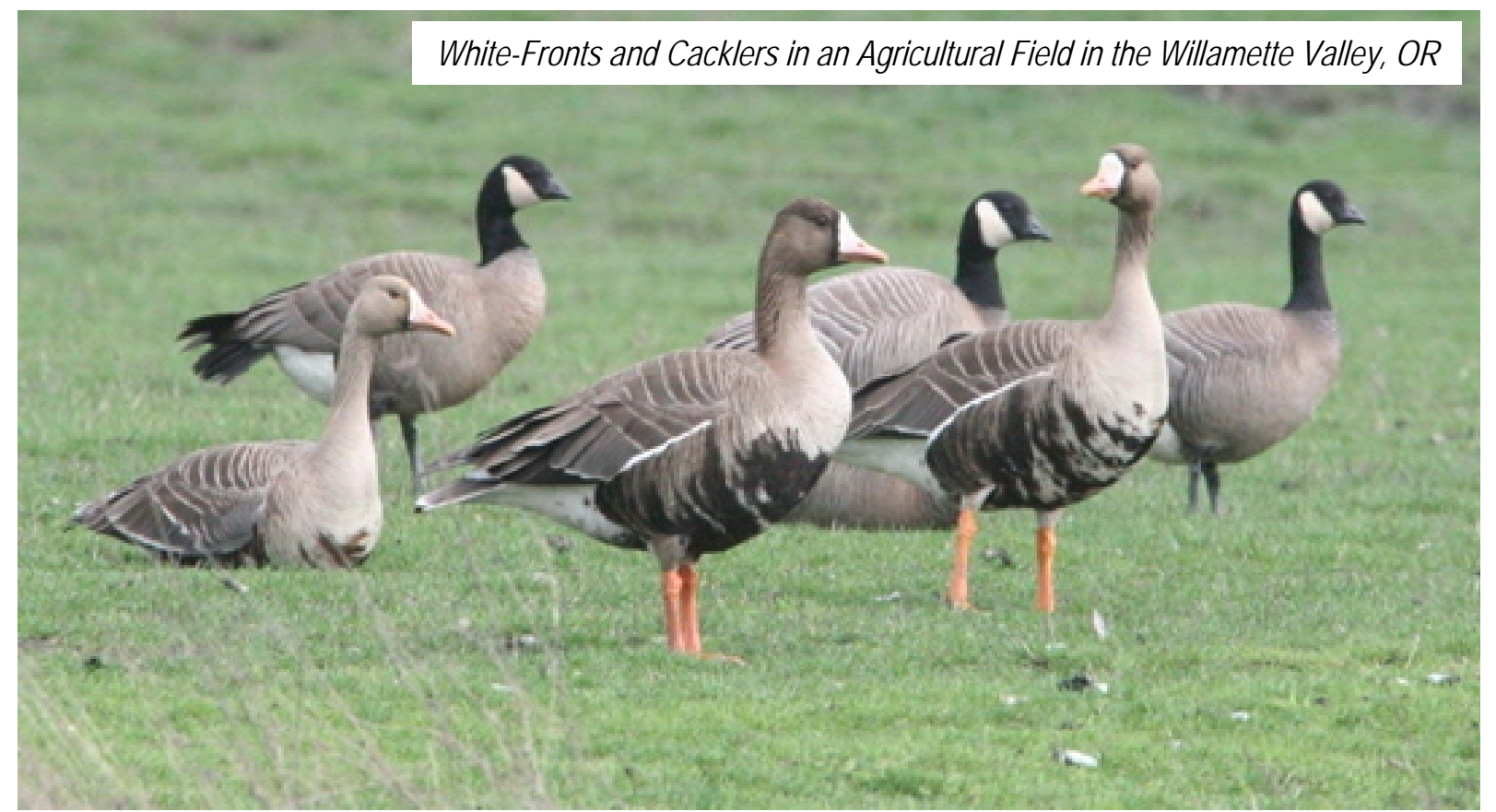

\section{Breeding Areas}

Nearly all Pacific white-fronts breed from the Alaska Peninsula north to the Yukon River, with the majority nesting on the Y-K Delta (Palmer 1976; Timm and Dau 1979). Aerial surveys, which are usually conducted in June, indicate that the Y-K Delta has hosted an average of nearly 97 percent of Pacific white-fronts over the past 10 years (Eldridge and Dau 2002; Conant and Groves 2002). About 75 percent of the population breeds in the narrow coastal zone while another 22 percent are dispersed across the interior of the Delta. The remainder nest in Bristol Bay and the Innoko River basin.

\section{Migration and Wintering Areas}

The fall migration of Bristol Bay Pacific white-fronts begins in early to mid-August. Geese that migrate along the Alaska Gulf Coast in late August and early September and pass through Cook Inlet and the Copper River Delta (Figure 2) before the hunting season opens may be of Bristol Bay origin (Hawkings 1982, Ely and Dzubin 1994); this assumption is based on a few band recoveries from Cook Inlet. The YK Delta Pacific white-fronts, unlike cackling geese, do not usually aggregate in concentrated staging areas. They apparently remain on the Y-K Delta or east of the Delta until late September (Figure 7) (Ely and Dzubin 1994).

The numbers shown in Figure 7 denote the primary wintering and staging spots of white-fronts and are in order of importance with " 1 " being high importance and "12" being lesser importance (Ely and Takekawa 1996). Fewer than 10,000 Pacific white-fronts winter in the Klamath Basin of northeastern California and southeastern Oregon; several hundred Pacific white-fronts overwinter in the lower Columbia River.

Alaska's Copper River Delta (Figure 2) is the last known major use area north of the Klamath Basin (Figure 4). There have been only two band recoveries in Southeast Alaska and one in British Columbia. As the population has increased, more Pacific white-fronts have been observed in western Washington and Oregon during September. 


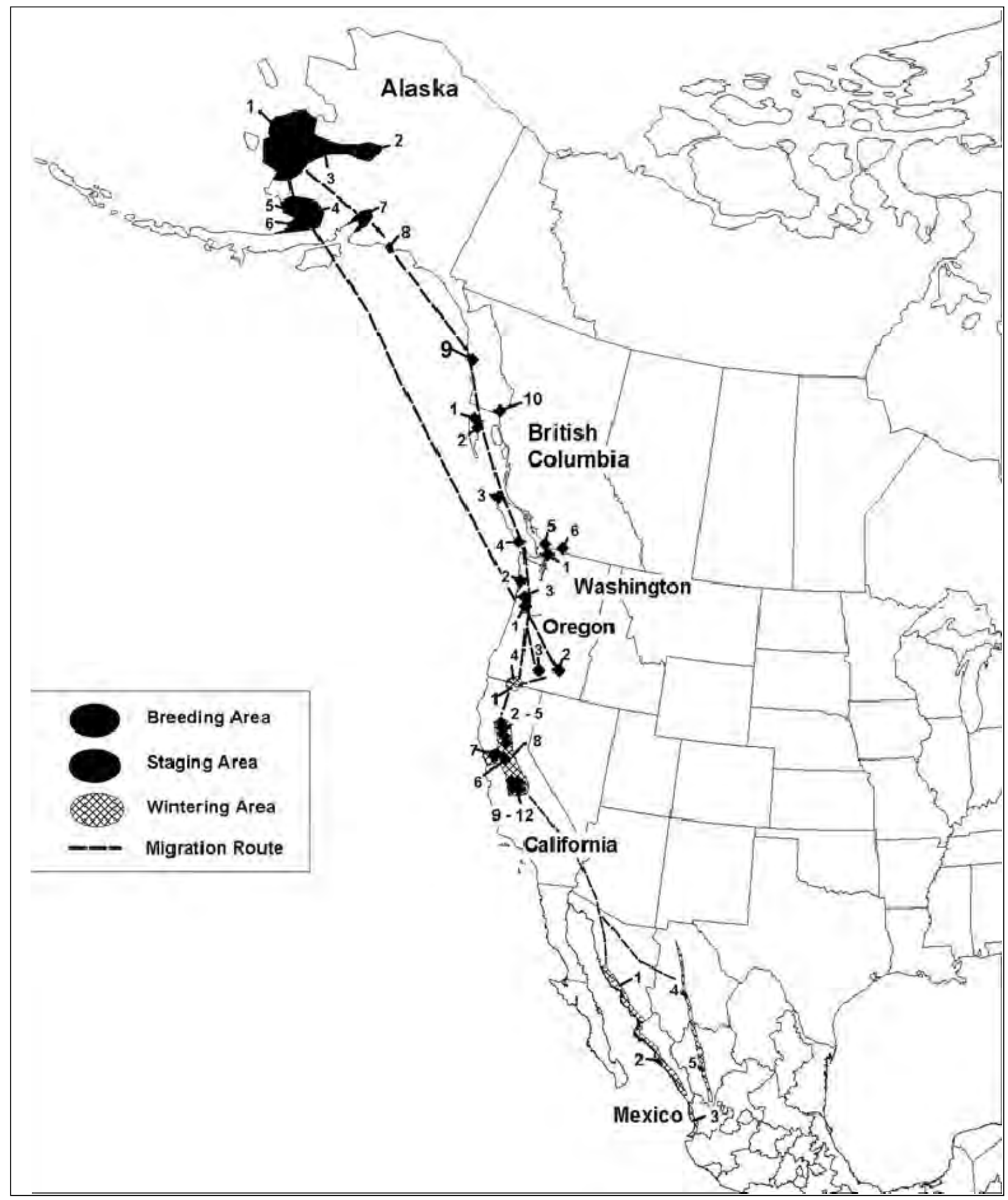

Figure 7: Important Staging and Wintering Areas for White-Fronted Geese (Pacific Flyway Council 1999)

It appears that most Pacific white-fronts move nonstop from the Y-K Delta to the mouth of the Columbia River, migrating through central and eastern Oregon in October before arriving at wintering grounds in the Klamath Basin and Sacramento Valley. The geese move through the same area again in January and February before heading northward to the breeding grounds in Alaska. In recent years, however, most of 
the population apparently has bypassed the traditional Klamath Basin staging area in the fall, migrating directly to the Central Valley of California. When migrating north however, white-fronts have increased in number in the Klamath Basin. The geese mainly concentrate on national wildlife refuges on the west side of the Sacramento Valley in the early fall because other habitats are limited. Increasing urbanization, changes in agriculture, hunting pressure and the large influx of Pacific white-fronts has limited habitat and resources in their wintering area.

As the fall and winter progresses, the Pacific white-fronts disperse into other parts of the Sacramento Valley and the Sacramento-San Joaquin River Delta. Recent trends (1998-2002) show significant numbers of Pacific white-fronts arriving in the Sacramento Valley by late September, with 100,000200,000 present by the first week in October. Although diminished in numbers from past years, the first arrivals in the Klamath Basin are seen about the end of August with the peak occurring in mid-October (USFWS 1999). These arrival dates are still true today according to USFWS surveys. A small percentage of Pacific white-fronts, mostly from Bristol Bay, migrate early through the Klamath Basin in September, overfly the Sacramento Valley, and winter in the northern highlands of Mexico (see below) (Ely and Takekawa 1996).

Recoveries from Pacific white-fronts banded in Alaska show a relationship between breeding and wintering areas (Lensink 1969). It appears that birds from the Y-K Delta stage and winter in the Pacific Flyway. The majority of recoveries from the three banding regions on the Y-K Delta occurred in California (Pacific Flyway Council 1987). ${ }^{2}$ Only 7 percent of the Pacific white-fronts banded in the Innoko River basin (Figure 2) have been recovered in California. These are likely "molt migrants" ${ }^{3}$ and comprise both Pacific white-fronts from the Y-K Delta and Tule white-fronts from Cook Inlet. The Innoko River basin hosts Pacific Flyway white-fronts, Mid-Continent white-fronts, and Tule white-fronts during the molt. The westernmost banding sites in the Innoko basin have produced the highest proportion of California band recoveries (>20 percent), which is congruent with the distribution of molting Tule white-fronts in the region.

Past banding in the Klamath Basin has indicated that Pacific white-fronts migrating through the Klamath Basin in September and early October were apt to be recovered in Mexico, whereas geese banded after 15 October are rarely recovered there (C. Ely, USGS, personal communication, 2010). The earlier birds are now known to be primarily from the Bristol Bay group (Ely and Takekawa 1996). At least 10,000 Pacific white-fronts winter in Mexico. Winter survey counts in Mexico conducted every third year by the USFWS indicate that the numbers of wintering geese range from 10,000 to more than 20,000 (USFWS 2001). Band recovery data indicate that the propensity of Pacific white-fronts to winter in Mexico is highest in birds from the southern part of the breeding grounds, particularly Bristol Bay. Bird banding data showed that over 90 percent of Pacific white-fronts from Bristol Bay wintered in the interior of Mexico (Ely and Takekawa 1996).

Recoveries in Mexico varied among geese banded in the north Y-K Delta (none in Mexico), middle Y-K Delta (2.5 percent), and south Y-K Delta (23 percent). Analyses of historical banding have shown that 9 to 10 percent of birds from the primary Y-K Delta breeding grounds are recovered in Mexico, primarily from the states of Sinaloa, Nayarit, and Sonora (Lensink 1969, 1986). Between 20 percent and 25 percent

\footnotetext{
${ }^{2}$ Bands recovered in California were as follows: 70.0 percent from the south Y-K Delta region, 90.5 percent were from the middle Y-K Delta region, and 84.6 percent were from the north Y-K Delta region.

${ }^{3}$ Molt migrants are defined as non-breeding yearlings that migrate to unfamiliar areas to clear habitat for young of that year.
} 
of band recoveries are from the interior highlands of Chihuahua and Durango. Ely and Dzubin (1994) suggest that the Pacific Flyway white-fronts wintering in the interior highlands may not be sympatric with Mid-Continent birds using areas further south and east in Mexico.

\section{Population History}

There are two subspecies of white-fronted geese that breed in Alaska and winter mainly in California: the greater white-fronted goose (A. albifrons frontalis), also called the Pacific Flyway Population of Greater White-Fronted geese, or Pacific white-front, and the Tule greater white-fronted goose (A. a. gambelli). Each of these subspecies is managed through different plans in the Pacific Flyway (Section 2.2).

In addition to the Pacific Flyway Population of white-fronted geese, there is a Mid-Continent Population of white-fronted geese (another population of $A$. a. frontalis). Some of the geese from Mid-Continent Population breed in interior and northern Alaska and are managed through a separate plan adopted by the Central, Mississippi, and Pacific Flyway councils in 1998.

Fall counts of Pacific white-fronts declined from a population peak estimate of 480,000 birds between 1966 and 1968 to a low of 73,100 in 1979 (O’Neill 1979; Timm and Dau 1979; Raveling 1984). Harvest restrictions instituted in the late 1970s and a conservation program begun in 1984 (Section 2.2.2) helped return the population to acceptable levels by 1996. Though growth slowed somewhat in the late 1990s, the population numbered 433,400 in 2001 and 600,000 by 2004, as determined by breeding and wintering ground surveys (Pacific Flyway Council 2004). The population this past year has grown to nearly 650,000 white-fronts (Figure 8).

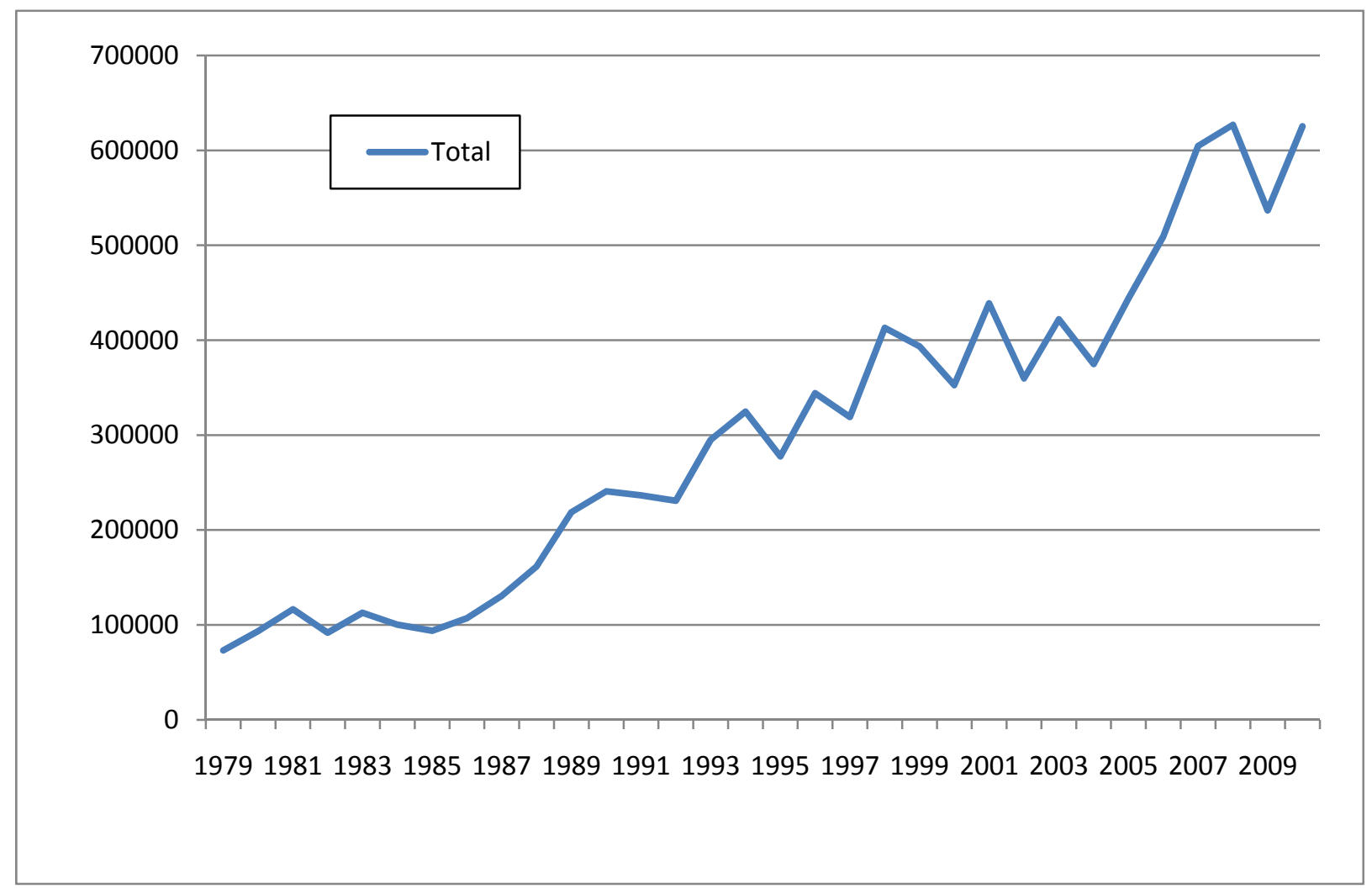

Figure 8: Total Population of White-Fronted Geese 1979-2010 (Pacific Flyway 1999) 
At the present time, the white-front population is higher than it has ever been, according to USFWS surveys (J. Fischer, USFWS, personal communication, 2010; Pacific Flyway Council 2010). The estimated population is nearly 350,000 birds greater than the management objectives set by the Pacific Flyway Council (Section 2.2.1) which has resulted in large impacts on agriculture. Special hunts have been initiated in an effort to alleviate crop depredation. However, so far there has been little success in lowering the population.

Lowering the population through hunting has been hampered by the fact that protection of the Tule whitefront is a top priority. Conservative bag limits are still in place and hunt areas are closed in California to protect this species. Until the Tule rebounds, it is unlikely that hunting will be a means of controlling the white-front population. Therefore, because conditions on breeding areas have been favorable and sport hunting continues to be controlled, it is likely that the Pacific white-front population will continue to increase.

\subsection{GOOSE MANAGEMENT}

\subsubsection{Pacific Flyway Council}

The federal governments of the United States, Canada, and Mexico, under the authorities of bilateral treaties and federal legislation, are ultimately responsible for the protection and conservation of migratory birds in North America. In the United States, this responsibility has largely been delegated to the USFWS.

The Migratory Bird Treaty Act implements various treaties and conventions between the U.S. and Canada, Japan, Mexico and the former Soviet Union countries for the protection of migratory birds. Under the Act, taking, illegal killing or possessing migratory birds is unlawful. The act also states that hunting seasons must fall between September 1 and March 10. The Migratory Bird Treaty Act authorizes state governments to adopt and enforce laws and regulations protecting migratory birds, as long as they are not inconsistent with those of the federal government. That is, state authority may be more restrictive than the federal authority, but not more liberal. Each state has constitutional and legislative mandates and a body of laws and regulations that direct the conservation and public uses of migratory game birds within their borders.

Migratory birds use four major migratory routes (Pacific, Central, Mississippi, and Atlantic flyways) in North America. Because of the unique biological characteristics and relative number of hunters in these regions, state and federal wildlife agencies adopted the flyway structure for administering migratory bird resources within the United States. Each flyway has its own council. In the U.S., the Pacific Flyway includes Alaska, Arizona, California, Idaho, Nevada, Oregon, Utah, Washington, and those portions of Colorado, Montana, New Mexico, and Wyoming west of the Continental Divide.

The Pacific Flyway Council is an administrative body that fosters cooperation among public wildlife agencies for the purposes of protecting and conserving migratory birds in western North America. The Council is composed of the director or an appointee from the public wildlife agency in each state and province in the western United States, Canada, and Mexico.

Each species and subspecies of waterfowl in the United States is managed separately by region. Management in each region is established by a regional council consisting of representatives from management agencies. Management strategies for waterfowl populations in the Pacific Northwest are developed by the Pacific Flyway Council. Plans are the primary tool for managing and making management decisions about individual species, subspecies, and populations. The management plans are subject to revision as new data and information about a waterfowl population are developed. 
Management protocols and implementation are first established by the Pacific Flyway Council and then by the USFWS and state fish and wildlife agencies. Because birds fly over more than one state in their migrations, management is handled by the federal government through the Pacific Flyway Council and the USFWS. Once protocols and strategies are agreed upon, they are incorporated into the management plan for that particular subspecies.

Scientific data is gathered annually on waterfowl populations. Changes in population dynamics and migration patterns within the Pacific Flyway require revision of management plans. These revisions, in turn, require research to determine the most effective ways to manage each goose species (J. Fischer, USFWS, personal communication, 2010). Targeting management strategies for changes in wintering and breeding areas can help forestall problems for Willamette Valley farmers while simultaneously maintaining the goals set by agency management plans for individual goose species.

The focal species for goose management in Oregon and southwest Washington is the dusky Canada goose. The dusky Canada goose is considered a "less successful" subspecies that has been displaced on wintering grounds due to the increase in cacklers (Pacific Flyway Council 2008).

In recent years, managers have had to act quickly to accommodate the dramatic increase in cackling geese in the Willamette Valley. In the 1980s and 1990s, little action was taken by the agencies because the cacklers were not expected to shift in such large numbers. When the rapid shift occurred, managers were not prepared to implement new management strategies that would accommodate cacklers in their newly chosen wintering ground. The agencies' lack of preparation resulted in larger than necessary expenditures of public funds and in actions that had little or no effect on the problem. Today, agency personnel recognize that it will be essential to plan for the worst-case scenarios in terms of migration shifts to prevent the crisis-mode actions that occurred with the rapid increase in the cackler population in the 1980s and 1990s (J. Fischer, USFWS, personal communication, 2010).

The Y-K Delta Goose Management Plan has guided conservation and harvest of the cackling goose for the past 15 years. The precursor of the Y-K Delta Management Plan was the Hooper Bay Plan, which was signed in January 1984 by representatives of the coastal states, the USFWS, and Alaska subsistence hunters. Representatives from Alaska, Washington, Oregon, and California attended a series of meetings in 1983, which led up to the 1984 agreement. The intent of the meetings was to identify critical problems with goose nesting, to agree on harvest restrictions, and to develop a broad-based conservation program (Pamplin 1986). Similar annual meetings have continued under the Y-K Delta plan to assure consistency between management plans for the Pacific Flyway and for the Y-K Delta. Through these efforts, the cackler population rose to about 192,000 birds in 2008 (J. Fischer, USFWS, personal communication, 2010).

Subsistence harvest is also covered by the Y-K Delta plan. This is a very important issue for Native people in both Alaska and Canada. Native people rely on subsistence hunting for food and as well as an important cultural activity. The Y-K Delta Goose Management Plan calls for restrictions on both the breeding and wintering grounds to protect cackling, white-fronted, and emperor geese (Chen canagica) as well as black brant (Branta bernicla nigricans). In order to ensure a viable supply of birds for subsistence harvest, the Y-K Delta Goose Management Plan calls for restrictions on hunting, egg harvest, and other activities that affect populations depended upon by subsistence users. These measures are aimed at protecting cackling, white-fronted, and emperor geese while maintaining subsistence opportunities for Alaskan and Canadian Natives. The plan requires that federal harvest management for all geese on the wintering grounds be weighed against the needs of subsistence users. The current restrictions are to ensure that the population reaches a level where harvest will have little impact on the population while still maintaining the target population objective. The plan requires that federal harvest management for all geese on the wintering grounds be weighed against the needs of subsistence users. 


\subsubsection{Management of Cackling Geese and White-Fronted Geese}

Goose species and subspecies are defined by the USFWS both geographically and by physical characteristics. For example, a cackling goose is any goose with a culmen (bill length) of less than $32 \mathrm{~mm}$ that breeds on the Y-K Delta in Alaska. Separating management by region and species/subspecies means that different management strategies are instituted for each species, subspecies, and population. Management strategies are based on population status, harvest, and migration change. Of these, population level is the most important factor in management of any particular subspecies. Another significant factor that can alter management plans involves human-goose conflicts on wintering grounds. For example, as goose depredation on agricultural lands escalates, hunts are enacted to lower the goose population.

\section{Cackler Management}

The current plan Pacific Flyway Management Plan contains measures that attempt to address the complexities of having two subspecies (duskies and cacklers) occupying the same wintering area. The objectives set by the plan are as follows:

- Achieve a population of 250,000 geese as measured by a 3-year average index of indicated breeding pairs, i.e. 27,660 breeding pairs, as determined by the Y-K Delta aerial breeding goose survey

- Promote an average annual population increase of 5 percent to 10 percent

- Manage for a winter distribution that allows for no more than 20 percent of the current population in the agricultural areas of the lower Columbia River and Willamette Valley ${ }^{4}$

- Maintain, manage, and enhance, where feasible, nesting, migration, and wintering habitats in sufficient quantity and quality to meet population objectives and public use goals

- Manage habitats and harvest to minimize crop damage consistent with Pacific Flyway plans and policies (Pacific Flyway 1999)

Increasing numbers of cacklers may result in more liberal season dates and bag limits as the population gets closer to its objective of 250,000. The Migratory Bird Treaty states that hunting cannot extend beyond March 10 so that the birds can feed and build up fat reserves for the long migration to the breeding grounds (Flowers 2010).

As the goose population increases, so will damage to agricultural crops and encroachment into urban areas. Revised management plans must include input from the Oregon Farm Bureau, Oregon Department of Agriculture Washington Farm Bureau, and Washington Department of Fish and Wildlife. The effects on agriculture were taken into account to a certain extent in the last management plan, but with increase in cacklers and white-fronts, more attention must be focused on crop damage.

The most dramatic changes in cackler numbers on the wintering grounds occurred in 1994 and 1995. During this time, numerous meetings of the Pacific Flyway Council were held in order to formulate an emergency management plan until a more permanent approach could be established. The result was a treaty among USFWS, the states of Oregon and Washington, Alaska Department of Fish and Game, and

\footnotetext{
${ }^{4}$ This objective is aimed at removing cacklers from the agricultural areas in the lower Columbia and Willamette Valley; the remaining 80 percent of birds would overwinter away from agricultural areas.
} 
the Alaska Natives. The agreement called for collar and banding studies aimed at monitoring harvest levels so that the cackler population could be managed to ensure that it would not be overharvested in either Alaska or the Pacific Northwest.

Currently, in Oregon, farmers feel goose depredation is affecting their crops to the point that their livelihoods are at risk. Starting in fall 2010, the Agricultural Depredation Plan formulated by the Pacific Flyway Council will be re-written to reflect current impact of cacklers on new areas in Oregon and southwest Washington. The cackler management plan will also be opened and proposals will be presented to lower the population goal to a level that will not pose further risk of depredation.

In Oregon, the cackler wintering population has grown from 25,000 in the late 1970s to nearly 400,000 in 2009 (Section 2.1.1) and is continuing to increase. In the late 1980s, Oregon and the lower Columbia River were included in the cackler surveys. Adding these areas caused the overall population estimate to increase, but managers still decided to institute changes aimed at returning the cackler population to return to its historical levels.

In recent years, there have been increasing numbers of migratory geese using urban areas. For example, the number of urban geese within the city limits of Salem has increased nearly 50 percent between 2005 and 2010 (B. Bales, ODFW, personal communication, 2010). Urban areas provide safety from hunting and agricultural hazing, lower concentrations of predators, and optimal food sources such as fine grasses in golf courses and recreational fields. Increased numbers of geese in urban areas have resulted in negative effects such as water contamination and damage to athletic fields and golf courses due to large concentrations of feces that make areas cosmetically less appealing and pose human health risks.

\section{Management of White-Fronted Geese}

The Pacific Flyway Goose Management Plan contains the following management goal and objectives for Pacific white-fronted geese (Pacific Flyway Council 2003):

- Goal: Identify the needs and responsibilities necessary to cooperatively manage numbers and distribution of Pacific white-fronts in order to maintain population viability and to provide for aesthetic, educational, scientific, and hunting uses throughout their range

- Maintain a population index of 300,000 as measured by a 3-year average projected fall index derived from indicated total geese on aerial surveys covering the Y-K Delta and Bristol Bay areas

- Maintain, manage, and enhance nesting, migration, and wintering habitats in sufficient quantity and quality to meet the population objective and public use needs

White-fronts have recently been exhibiting changes in behavior that are thought to foreshadow a similar northward shift in wintering areas. For example, it has been observed that goose populations have "scout" birds that look for better habitat and food sources (Pacific Flyway Council 2008). Once the scout birds have identified a suitable wintering area, increased numbers of geese are seen in those areas during spring and fall migrations. Within a few years, the main population is staging longer in these areas and eventually will remain on the former staging grounds throughout the winter.

This is the same type of trend observed with cacklers starting in 1985. At first, several hundred cacklers started wintering in the Willamette Valley. By fall 1994 and winter 1995, the number of cacklers wintering in the valley had increased nearly 50 percent as the geese shifted from the Sacramento Valley northward (Warren 2007). 


\section{StUdy Methods}

Data and information for this thesis were obtained from a review of pertinent literature and unpublished data as well as from original field data.

\subsection{LITERATURE REVIEW}

Several types of data were analyzed in order to address the questions presented in Section 1:

- Historical breeding and wintering surveys

- $\quad$ Bird band data

- Harvest data

- Agricultural data

- Climate and weather data

Pertinent literature included USFWS data (published and unpublished), studies conducted by universities, ODFW data, journal articles, and some unpublished data. Of these, the most pertinent were the USFWS data. ODFW harvest data also played a significant role in addressing the project's questions and aided in identifying patterns during the comparison of climate and agricultural data (Section 4).

Only data and information from 1975 to 2010 were considered for this thesis. This time frame was chosen because it encompassed the period before, during, and after the postulated shift northward. Trends in migration changes (if any) would be evident in data generated in these years. The same time frame was used for weather and climate data also.

\subsubsection{Historical Breeding and Wintering Surveys}

Data from past breeding and wintering surveys between 1975 and 2005 were compared with current surveys (2005-2010) in order to detect changes in area usage, migration patterns, and timing. Very little data prior to 1975 exist. The most complete set of data is derived from annual breeding and wintering ground surveys conducted by the USFWS. USFWS began collecting these data in the 1950s from field observations and aerial surveys. Combining these data produces an average that is the most realistic population estimate for any given year. The data from USFWS current surveys are derived from the surveys conducted over several decades. All aspects of the survey method have been refined over the years so that errors are minimized and so that the surveys result in an accurate picture of the total population and any changes that may have occurred. In addition to ground surveys, USFWS uses photographic data, banding, and aerial surveys. The protocols also assure the consistency of data collection from one year to the next, allowing easy comparison of data collected decades ago to that collected more recently.

\subsubsection{Historical Breeding Ground Information}

Breeding ground surveys occur in Alaska's Y-K Delta (Figure 1) where USFWS randomly samples waterfowl nests to determine annual breeding success. USFWS protocols are followed yearly on the Y-K Delta for both cacklers and Pacific white-fronts in mid- to late June. USFWS provided an opportunity to 
participate in a Y-K Delta ground survey crew during the summers of 2009 and 2010. Aerial surveys were conducted in July when the geese are in molt and unable to fly. During this time, the surveys are easier to conduct because the geese tend to gather together. The colony locations are marked with GPS coordinates which ensures that they are not counted twice.

\subsubsection{Banding Data}

Bird banding is an important source of information about bird populations, bird longevity, and behavior (territorial behavior, territory size, fidelity to territory, and reproductive behavior), especially dispersal and migration. Banding is supervised by the Federal Bird Banding Laboratory for USFWS and the Canadian Wildlife Service. This laboratory holds the database for all band data in the U.S. and Canada. All data from birds marked with a federal band are submitted to this laboratory; 99 percent of the banded birds in North America carry federal bands. The other 1 percent includes aviary, or private collection, birds.

Banding can be accomplished with metal leg bands or with other methods that are more visible to the observer, such as a "tarsus" band ${ }^{5}$ or neck collar. These bands are more visible than other types of bands, which means that they can be tracked without handling the bird again. A "mark-capture" technique can be used to estimate population sizes. Birds are marked and then recaptured. The ratio of the number of birds marked originally compared to those recaptured allows the total population to be estimated.

Analysis of banding information from waterfowl is completed annually. These data are used in development of hunting regulations and for detecting changes in waterfowl populations. Banding data can be used to assess hunting pressure, estimate productivity and survival and to measure the vulnerability of the age/gender classes to hunting pressure.

Band data specific to pertinent areas were reviewed for this project. Most data were obtained from USFWS' Bird Banding Laboratory. For cacklers, the geographic area encompassed by the data used for this project extended from the southern Willamette Valley in Oregon through the State of Washington. Washington State data were included because it was speculated that it could reveal any northern shifts of this species. Data reviewed included live sightings of collared or banded geese and data reported from harvested geese or those found dead.

For white-fronts, the geographic range of the data included Washington, Oregon, and California. Because so few white-fronts have been included in banding studies in the past, any band data at all for this species were considered useful to the project.

\subsubsection{Harvest Data}

Harvest data were obtained from three sources: 1) wing and parts survey ${ }^{6}$ information, 2) Harvest Information Program (HIP) data, and 3) permit zone data. The first two types of data were obtained from USFWS. Permit zone data are collected at check stations in the Northwest Permit Zone Area (Figure 9) and were obtained from ODFW. Combining the data from these three sources was expected to show migration trends based on the number of cacklers and white-fronts harvested over the years.

\footnotetext{
${ }^{5}$ A tarsus band is placed on the leg and has three characters that can be read from a distance with a spotting scope.

${ }^{6}$ USFWS looks at certain features on wings and tail feathers of harvested birds. The bird “parts” are voluntarily donated to USFWS by hunters for this purpose.
} 


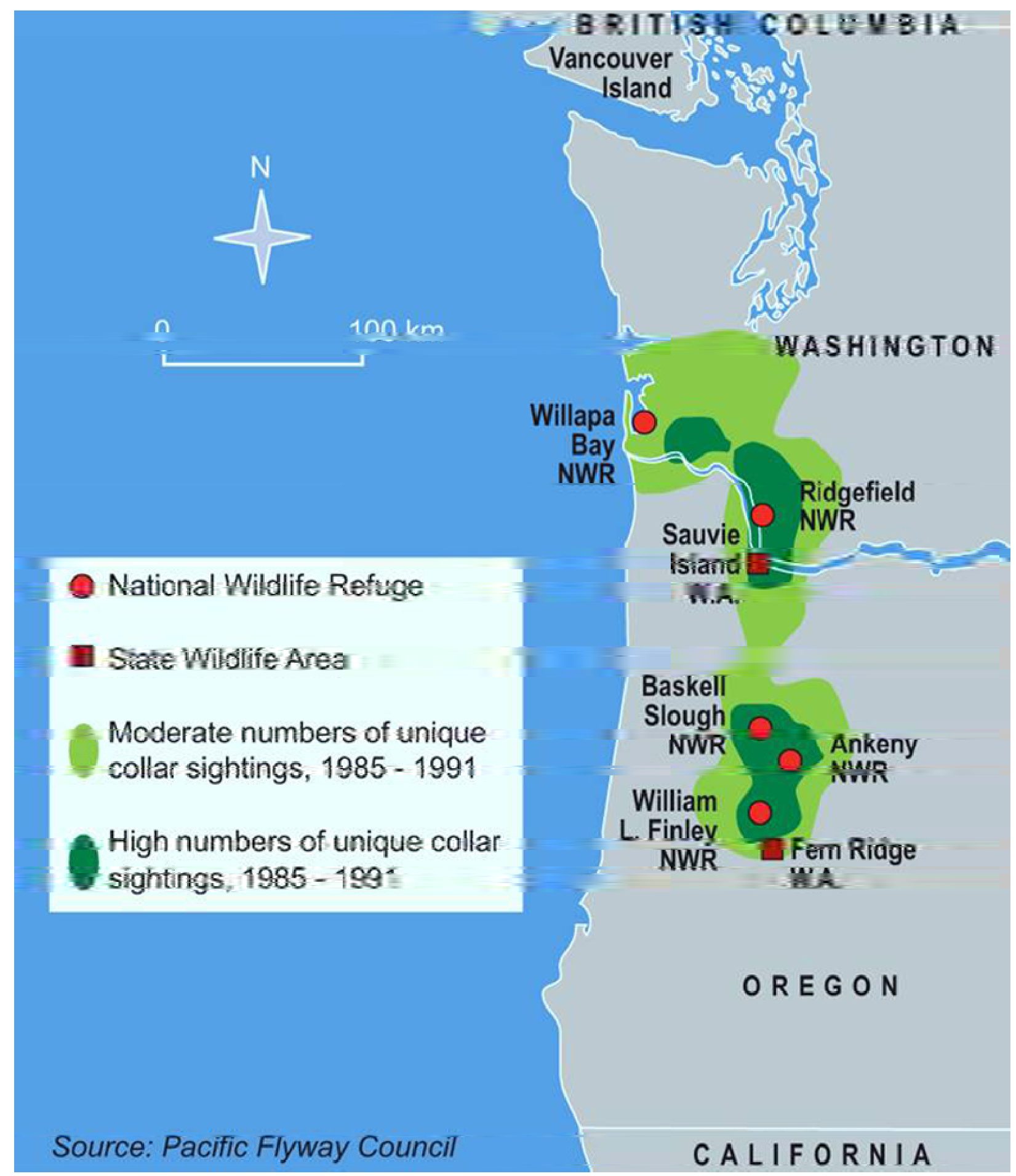

Figure 9: NW Permit Zone (Warren 2007)

USFWS conducts a voluntary "wing and part” survey on an annual basis. This information, combined with harvest rates in the HIP allows USFWS to estimate total harvest numbers for hunting zones nationwide. In addition, USFWS can determine the species and subspecies harvested by hunters. 
Through HIP, state wildlife agencies and USFWS are developing more reliable estimates of all migratory birds harvested throughout the country. These estimates give biologists the information they need to make sound decisions concerning hunting seasons, bag limits, and population management. HIP is based on a voluntary survey of selected migratory bird hunters in the United States. In simplest terms, the state wildlife agencies collect the name, address, and some additional information from each migratory bird hunter in their state and send that information to USFWS. USFWS then randomly selects a sample of those hunters and asks them to provide information on the kind and number of migratory birds they harvest during the hunting season. Those hunters' reports are then used to develop reliable estimates of the total harvest of all migratory birds throughout the country.

Harvest data is also gathered from the Northwest Permit Zone in Oregon and Washington (Table 1) where, by law, all hunters must submit every goose harvested at check stations for examination to determine species and subspecies.

Table 1: Permit Zone Harvest Data for Cacklers and White-Fronts, 1985-2010 (ODFW 2010)

\begin{tabular}{|c|c|c|}
\hline & Cacklers & White-Fronts \\
\hline 1984-85 & 0 & not included \\
\hline $1985-86$ & 8 & not included \\
\hline 1986-87 & 19 & not included \\
\hline $1987-88$ & 54 & not included \\
\hline 1988-89 & 26 & not included \\
\hline 1989-90 & 16 & not included \\
\hline $1990-91$ & 18 & not included \\
\hline 1991-92 & 42 & not included \\
\hline 1992-93 & 36 & not included \\
\hline 1993-94 & 72 & not included \\
\hline 1994-95 & 1,220 & not included \\
\hline $1995-96$ & 1,758 & not included \\
\hline $1996-97$ & 2,503 & not included \\
\hline $1997-98$ & 3,446 & 44 \\
\hline 1998-99 & 5,641 & 45 \\
\hline 1999-00 & 7,302 & 18 \\
\hline 2000-01 & 4,972 & 45 \\
\hline 2001-02 & 3,676 & 14 \\
\hline 2002-03 & 4,381 & 26 \\
\hline 2003-04 & 3,631 & 16 \\
\hline 2004-05 & 6,789 & 46 \\
\hline 2005-06 & 4,734 & 47 \\
\hline 2006-07 & 5,505 & 20 \\
\hline 2007-08 & 5,899 & 50 \\
\hline 2008-09 & 6,221 & 172 \\
\hline 2009-10 & 6411 & 68 \\
\hline
\end{tabular}


Checking species and subspecies is necessary in order to monitor whether or not Dusky Canada geese are inadvertently being taken. Because duskies are a "species of concern," there are limits on how many duskies can be harvested per season. If that quota is reached, hunting is closed. Check station personnel measure certain physical attributes of each goose and record species and subspecies. This further refines the data on specific numbers of Canada geese, cackling geese, and Pacific white-fronted geese.

\subsubsection{Radio Transmitter Data}

Data on goose movements and locations can be revealed through use of radio transmitters. Information for this thesis was obtained by placing radio transmitters on geese as part of a study being conducted by a Ph.D. candidate at Portland State University. The study focused on Benton, Linn, Lane, and Polk counties. Geese were captured on the Finley Wildlife Refuge near Monroe, Oregon, using bait traps. The radio transmitters were mounted on neck collars and placed around the necks of the geese. Approximately seventy birds were radio-collared over a two-year span. The birds were then tracked during their wintering movements using "relocators" which send a signal when an observer is near a radio-collared goose. The transmitters' batteries last about six to seven months in a radio collar. Since collaring occurred in December, January, and February, the radios cease to operate in June, July or August respectively.

\subsubsection{Interpretation Aerial and Still Photographs}

Historical and current aerial photographs of the Y-K Delta were obtained and topographical features analyzed for this thesis. In conjunction with other breeding ground surveys, aerial surveys are conducted to estimate nesting success and adult bird populations. Random transects are generated using a computer program (ArcGIS) ${ }^{7}$. The plane flies transects and "scatter shoots" the entire transect with a digital camera to ensure all waterfowl are recorded. The photographs are then analyzed to determine species and subspecies of geese. Aerial photos taken for this project were interpreted by USFWS and the data were made available to the author.

Counts of geese on the ground from still photos are often more accurate than counts made in the field (J. Fischer, USFWS, personal communication, 2010). Geese typically land in massive flocks and are constantly moving across a field while feeding. The movement can be "stopped" by taking still photos of the flock at times in sequence. The photos can then be analyzed to identify each species and subspecies, including marked birds. The number of birds of each species and subspecies in each flock can also be obtained. Though on-site viewing through a spotting scope is useful, a more definitive estimate can usually be obtained with photography.

\subsubsection{Agricultural Data}

Agricultural data was gathered from U.S. Department of Agriculture, Oregon Department of Agriculture, and California Food and Agriculture Department. Each provided historical, current, and future trends in agriculture. This project focused on the period between 1970 and 2010. The agricultural data reviewed included farming practices in Central Valley California and the Willamette Valley in Oregon prior to the migration shift of cacklers. Agricultural practices during and after the migratory shift were examined to identify changes in potential food sources for the geese. Records from the Oregon Department of Agriculture were reviewed to determine the crops grown in the Willamette Valley and the percentage of each crop between 1980 and 1995 (ODA 2009), the greatest period of expansion for cacklers. Analysis of

\footnotetext{
${ }^{7}$ ArcGIS is a highly accurate, geography-based system designed to provide useful information for decision-makers. It allows easy production of data, maps, globes, and models that can be easily accessed by the user in the field and the office.
} 
more recent data was expected to reveal if the northward shift of cacklers is expected to be maintained or expanded and if a similar shift based on preferred foods would be expected for white-fronts.

\subsubsection{Climate and Weather Data}

Analysis of weather patterns and data was an important part of determining the correlation between the cacklers' and white-fronts' northward shift and climate change. Average winter temperatures, snow levels, and frequency and severity of winter storms in the Willamette Valley, central Washington, and California's Sacramento and Central valleys were reviewed and compared to increased usage of the Willamette Valley by geese for wintering.

\subsection{FIELD STUDIES}

In addition to analyzing historical survey data, original data were collected in the field and were used to address the questions posed in this thesis. The data were also entered into the USFWS database. Data for both breeding grounds and wintering grounds were collected. The data were collected by the author in strict adherence with USFWS protocols, which allows the data to also be used by the Oregon Department of Fish and Wildlife and by the Pacific Flyway Council. Collected data were submitted to the USFWS database managers to assure that its acceptability for inclusion in the database.

Winter data collection occurred in coordination with USFWS' annual wintering ground surveys. The annual survey involved ground and aerial surveys as well as reading “collars.” More than 400 hours were spent in the field and more than 300,000 geese were logged. Data collected during the wintering ground survey were compared to those obtained on the breeding grounds for that year. Consistency or inconsistency of the numbers gives managers important information about the welfare of the population for that particular year including, breeding success, hatching survival, percent of eggs per female, and more. This information is used in establishing sport bag limits, subsistence harvest or in identifying special needs a particular species or population might have.

Winter fieldwork for this project was carried out in two consecutive years: 2008/09 and 2009/10. The area covered extended from Eugene, Oregon, to the Ridgefield National Wildlife Refuge in southwest Washington. USFWS, ODFW and Washington Department of Fish and Wildlife staffs have certain areas in which they collect data; the fieldwork performed for this project looked at areas not already covered by biologists from those agencies.

Areas are typically broken up by county with one survey per week in each county. In addition to specific areas that are surveyed weekly, the "Oregon General Zone" was surveyed by the author for a more complete survey (Figures 9 and 10). The general zone is rarely surveyed so additional data was collected beyond what was collected within the permit zone boundaries. The General zone extends from Portland to Eugene east of the I-5 freeway. Surveys were done three days a week, each day in a different survey area (county) in both the permit and the general zone.

Surveys typically begin in early morning at roosting areas as the geese are leaving for preferred feeding areas. The birds were followed by car to the feeding areas where they were counted and species/subspecies identified. The surveys were conducted with a spotting scope and binoculars as well as a digital camera. Photographs were particularly useful because counts could be conducted later from the pictures, which served as a verification of counts done in the field, thus lowering the margin of error. 


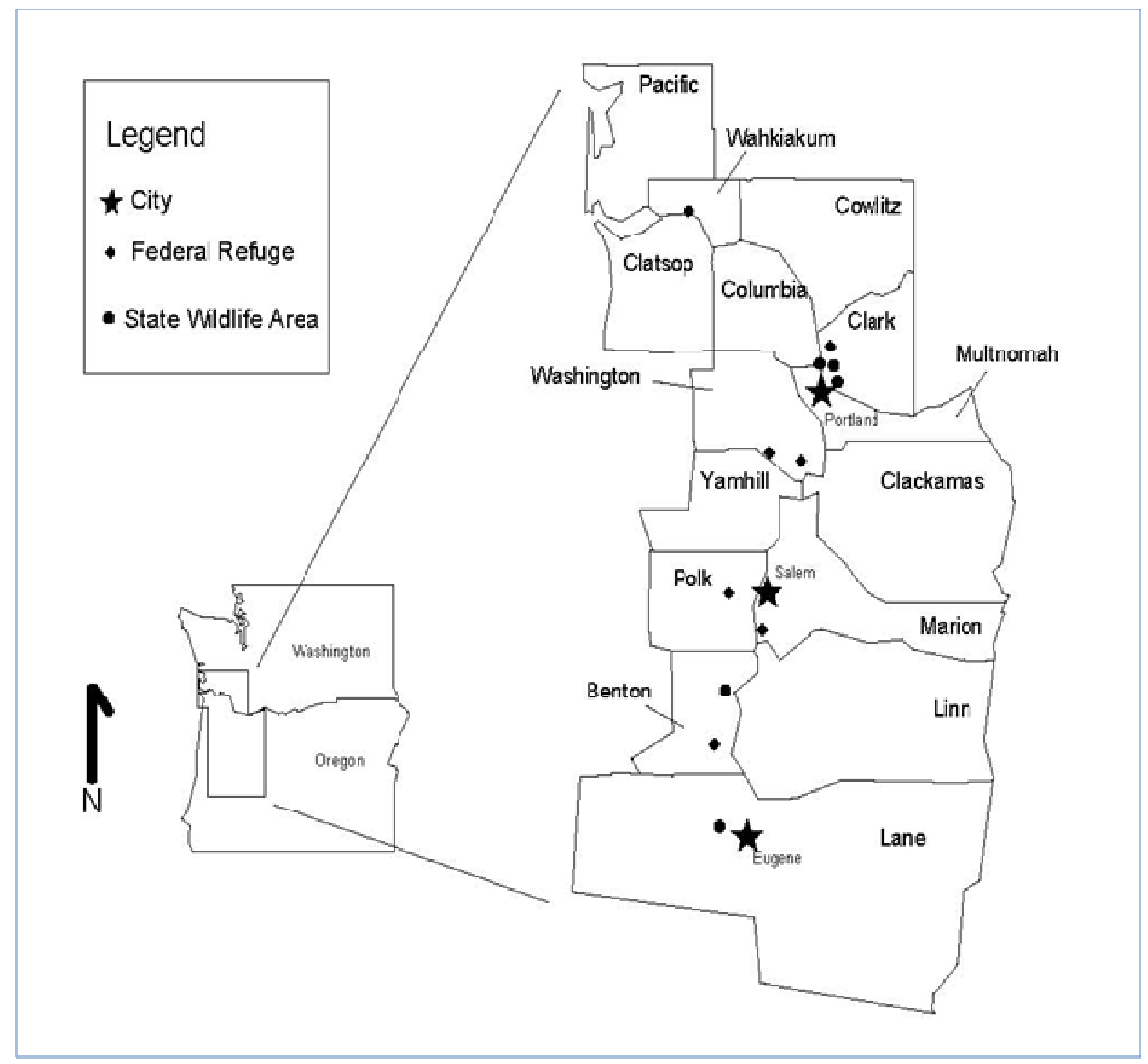

Figure 10: Areas Surveyed for Wintering Geese, 2008/09 and 2009/10

Each road in a survey area was covered to assure that the observer was seeing as many geese as possible. In some cases, access was limited because roads were private. Some areas had very few roads. This limited counts to areas that could be easily seen which meant, in some cases, that the counts were merely representative of the total number of birds in an area. In cases where roads were far from the goose flocks, it was difficult to identify species and subspecies. These limitations were noted on each data sheet. Inconclusive data sheets were eliminated from the final documentation.

A data sheet (Appendix A) was completed for each group of geese encountered. Information collected included date, time, bird location, number of birds of each subspecies, number of marked birds, name of the closest refuge, the latitude and longitude of the encounter location, and the total number of geese observed. The data were obtained from direct observation using binoculars, spotting scope, and camera with telephoto lens. The camera enabled groups of geese to be recorded for later species confirmation and, because the telephoto lens was more powerful than the spotting scope, made bird collars easier to read. This method allowed 100 percent success in reading collars on cackling geese in the 2009-2010 field season. 


\subsection{BREEDING SURVEYS}

The USFWS conducts breeding ground surveys in Alaska's Y-K Delta. Waterfowl nests are randomly sampled to determine annual breeding success. Random sample areas are generated by computer; usually 80 to 85 sites are surveyed. A customized program within ArcGIS generates the randomized selection of 85 plots each year. Plots selected do not overlap any plots surveyed in the past 5 years. Boundaries of the survey area include lands on the Yukon Delta National Wildlife Refuge (Figure 1) containing medium and high nest densities of spectacled eiders because of their Endangered Species Act listing and geese. The nest densities are based on aerial and ground observations made between 1985 and 1993 (USFWS unpublished data). Because annual access cannot be assured, privately owned high density nesting habitat near Kokechik Bay, two parcels on south Nelson Island, and several tracts near Hazen Bay are excluded.

Between 1994 to 1997 and 2000 to 2010, plots were selected within an area $716 \mathrm{~km}$ square that comprised 5.6 percent of the total coastal zone of the Y-K Delta. Prior to 1994 and in 1998 and 1999, plots were selected within a slightly larger portion of the coastal zone. Each plot measures $800 \mathrm{~m}$ by $400 \mathrm{~m}$ and is surveyed on foot. The location of each nest found is recorded along with the number of eggs, egg condition, species, and estimated date of hatching.

Hatching is estimated by using historical data from past breeding ground surveys and studies that focus on incubation and hatch. During the nest plot survey, eggs are floated in water to determine hatch date. Eggs will float differently depending upon their maturity. A hatch date for the season can be determined by averaging the number of floating eggs for each species. Each species or subspecies typically will lay eggs at slightly different times, resulting in a range of hatch dates for any given season on the Delta.

Breeding surveys are time-critical and must be conducted as soon as the ice melts on the Delta, usually between May 26 and June 15. For this project, 17 nest plots within a 20-square mile area were sampled within a 15-day period. The nests occurred in a variety of habitats including upland, coastal, riparian, grassy plains, mudflats, and “pothole” ponds.

Each plot is surveyed by two people. Each person walks half the plot area following a GPS and proceeding in a zigzag manner, checking to make sure that all the area is covered. During the survey, birds flushing from nests are noted and the species identified. If unoccupied nests are found and no bird flushes, down and feathers in the nest are used to determine the species. All species of bird including waterfowl (duck, goose, swan), gulls, shorebirds, and songbirds are noted. An example of the survey form is found in Appendix A. For each nest, the following information is recorded:

- Plot number

- GPS location

- The name of the observer

- Goose species

- Nest location

- Number of eggs

- Maturity of the eggs (estimated hatching date)

- Evidence of predation in the nest

- $\quad$ Nest status (active or non-active) 
During the 2009 and 2010 survey periods, 15 and 10 plots, respectively, were surveyed for this project. Figure 11 depicts the plots surveyed in 2010.

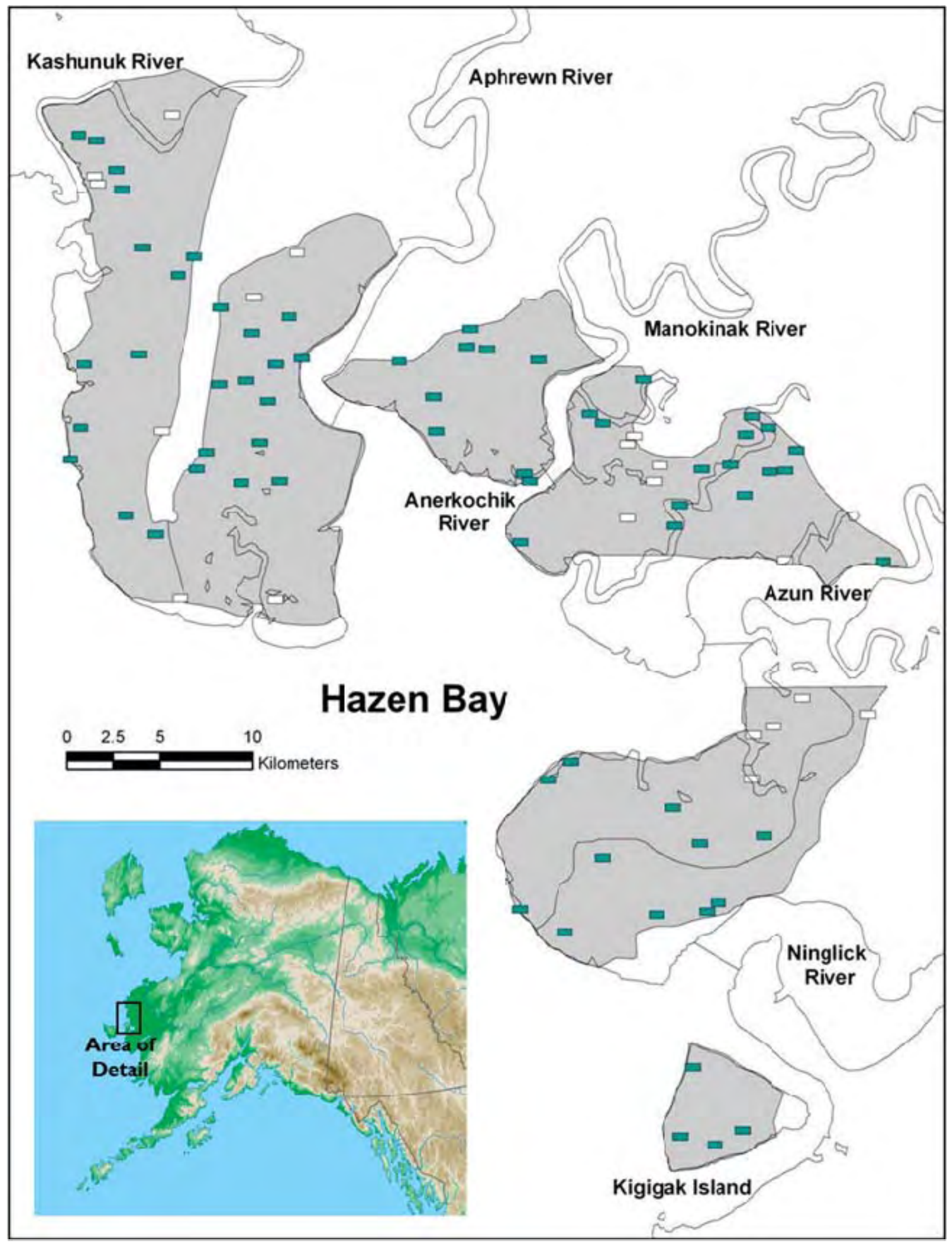

Figure 11: Nest Plot Survey Area, 2010 (USFWS 2010) 


\section{RESULTS}

All data and collected from sources identified in Section 3 were reviewed and analyzed for completeness and applicability. Data that were not considered complete or accurate were excluded from the analysis. Data and information from studies that were not yet complete or appeared to be less applicable to the questions addressed by this thesis were not used in the data synthesis and analysis. For example, the radio transmitter study has not yet been concluded and the data from it were not included in this thesis.

In addition, the HIP harvest data, while helpful, was not as useful because its scale was too broad. The numbers harvested gave an idea of the overall harvest, but with a large margin of error. It also did not clearly identify where the birds were harvested, e.g. birds were identified only as having been harvested in Oregon. The USFWS data from breeding and wintering areas was much more useful because it could be used to cross-check other population estimates.

\subsection{WINTERING AND BREEDING GROUND SURVEYS}

Data obtained in the course of this project indicate that cacklers are arriving on the breeding grounds and nesting later than in previous years. The incubation date for broods is beginning to extend beyond the historical May 26 to June 10 "window" according to results from the nest plot survey. It is thought by USFWS biologists that this is due to the fact that cacklers and white-fronts are remaining on their wintering grounds past their historical departure dates (J. Fischer, USFWS, personal communication, 2010; USFWS 2009).

Cacklers also appear to be arriving on the wintering grounds earlier as well. This year, large flocks of cackler were sighted in the Willamette Valley during surveys in late September, nearly a month earlier than usual. This trend has been seen in years past, but this past fall was an extreme case. Data collected from surveyors corroborates this behavior (ODFW 2010). Comparison of this information with historical arrival and departure dates indicates a change in migration patterns nearly as significant as the northward shifts of the 1990s (Figure 12).

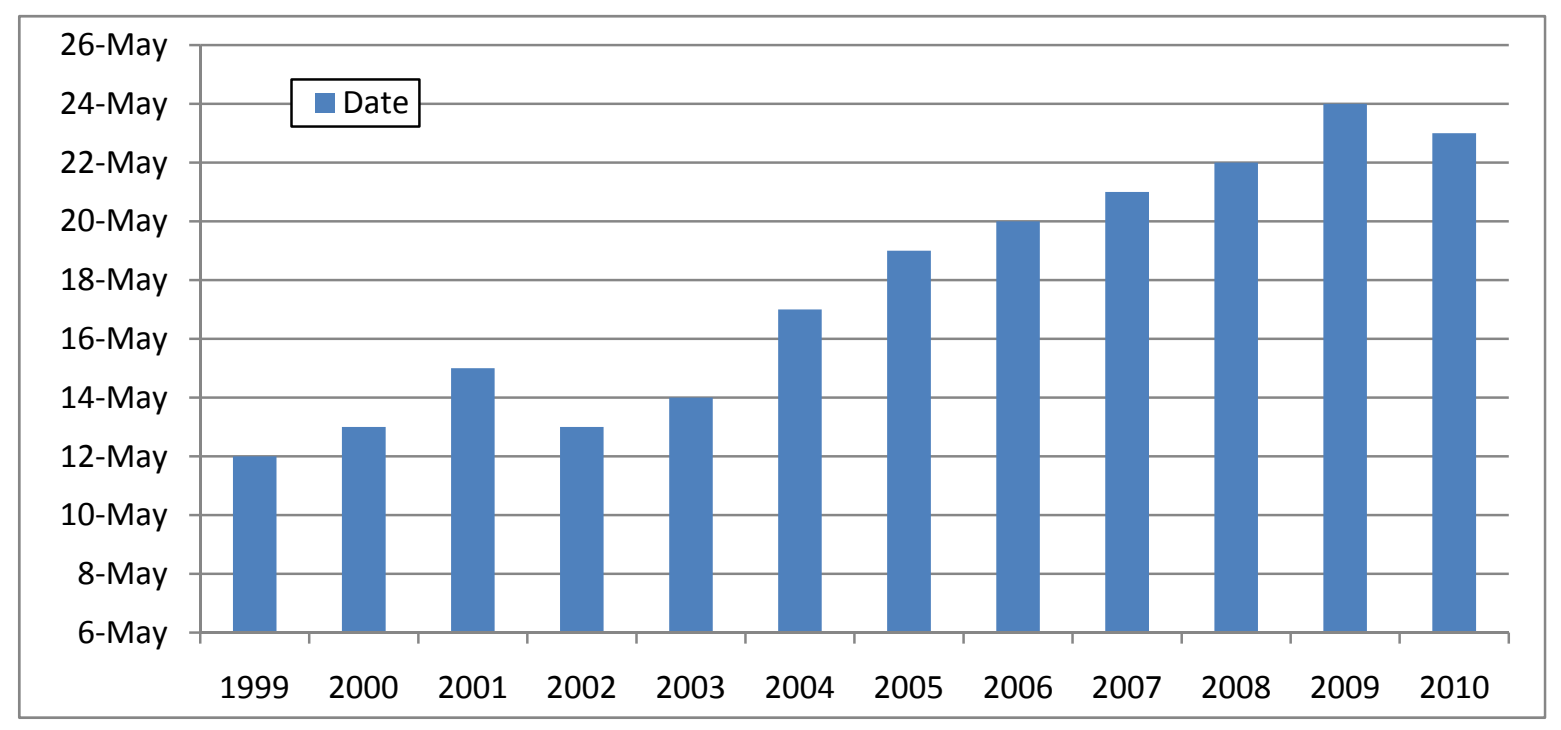

Figure 12: Departure Date of Cackling Geese from Wintering Grounds, 1999-2010 
Direct observations of the breeding grounds as part of this project revealed that cacklers prefer potholes, uplands, and grass plains near a water source for nesting. White-fronts seemed to prefer uplands and grassy plains, but seemed to have little trouble nesting elsewhere as this species was observed in a variety of habitat types. According to data from nest plot surveys conducted over the past 30 years, the habitat of the Y-K Delta is changing. Winter temperatures have increased $2.2^{\circ} \mathrm{F}$ on the Delta between 1949 and 1998 (USFWS 2009). Substantial warming has also been documented in the Arctic, especially in the fall and winter months (USFWS 2009).

As a result, potholes appear to be holding water for a shorter time each year, likely because moisture is being lost from the ground in the Y-K Delta (USFWS 2009). This, in turn, is due to permafrost melting because of the warmer temperatures. Permafrost, i.e. permanently frozen ground, comprises soil, sediment, or rock that remains at or below $32^{\circ} \mathrm{F}$ for at least 2 years (USFWS 2009). North of the Brooks Range in Alaska, permafrost is continuous, extending from a few inches to nearly 1,000 feet below the ground surface (USFWS 2009). Permafrost supports the ground surface, controls soil temperature and moisture, modifies micro-topography, controls subsurface hydrology and rooting zones, and influences nutrient cycling. Recent studies have shown that permafrost is warming throughout most of the region. For example, the soil in the Arctic Coastal Plain in Alaska has warmed $5^{\circ} \mathrm{F}$ to $7^{\circ} \mathrm{F}$ over the period from 1977 to 2003 (USFWS 2009). During the 2009 and 2010 surveys on the Y-K Delta, erosion was evident on shorelines of the waterways and the Bering Sea. Because permafrost previously held them together, river banks and coastal cliffs are beginning to collapse in areas where melting has occurred. The alteration of the Delta due to permafrost melting may have significant impacts on waterfowl habitats in the future.

As mentioned in Section 2.1.2, the Pacific white-front population declined precipitously between 1966 and 1979, resulting in revised management including harvest restrictions. The population subsequently rebounded and, today, the white-front population exceeds the management objectives by more than 300,000 birds. In the last few years, USFWS ground survey crews have seen an 18 percent increase in white-front sightings in the Willamette Valley (Figure 13). These sighting have occurred mostly in early October when the geese may have been staging to migrate south. Though white-fronts previously overwintered in California, the numbers remaining through the winter in the Willamette Valley and southwest Washington are increasing. The highest count of white-fronts took place during the 2008/2009 season. During this time period, thousands, rather than the expected hundreds, of white-fronts were counted in the wintering ground surveys. The overall numbers were combined by USFWS to come up with an index of the white-front population for that winter.

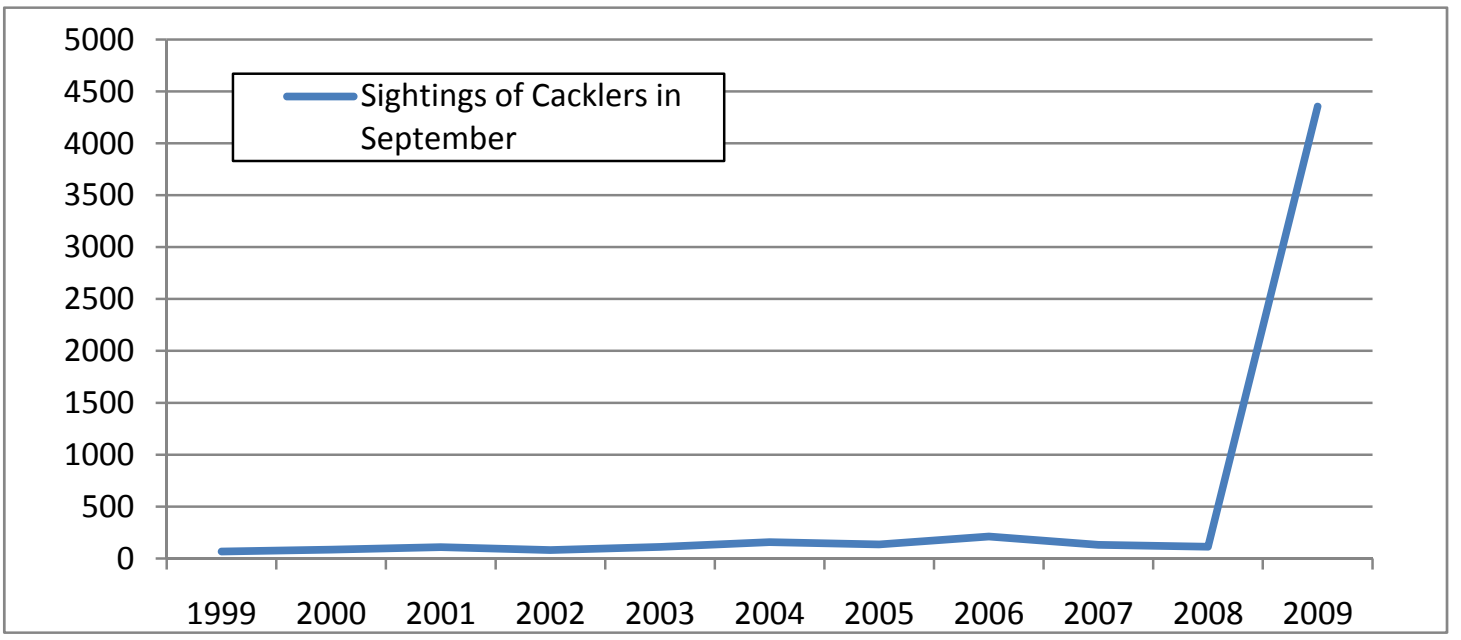

Figure 13: September Sightings of Cacklers in the Willamette Valley, 1999-2010 (Pacific Flyway Council 2010) 


\subsection{BIRD BANDING DATA}

Bird banding data was obtained from the Bird Banding Laboratory in 2009. More than 10,000 band reports for cackling geese between 1985 and 2010 and 1,000 reports for white-fronted geese for 1995 to 2010 were analyzed for this thesis.

Correlation data analyses indicated that there was a direct relationship between temperature and the number of banded cacklers harvested in Oregon (Figure 14). Starting in the 1994-1995 season, the majority of cackler band returns have been from Oregon. Cackler band returns for California decreased at a rapid rate starting in 1994. Band data also showed that the number of bands recovered in Washington increased by 225 percent between 1999 and 2010.

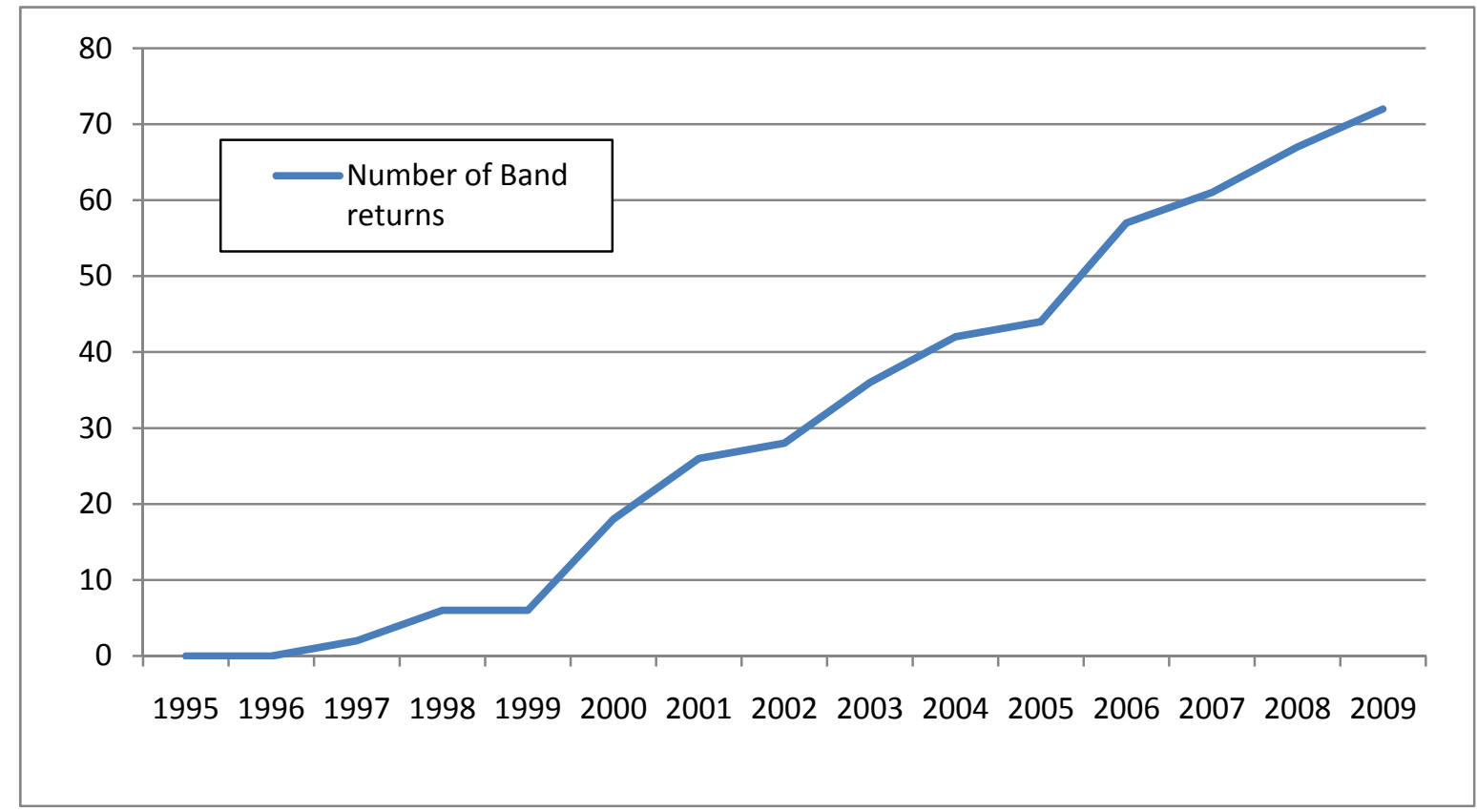

Figure 14: Number of Cackler Band Returns in Washington State, 1995-2009 (Pacific Flyway Council 2009)

In years with warmer than average winter temperatures, more banded cacklers were harvested in the Willamette Valley. In cooler winters, more bands were reported from California. A similar analysis was conducted with data from Oregon and Washington recorded over the past five years. The Pacific Northwest experienced a much more severe winter than usual in 2008-2009. Snow and unusually cold temperatures occurred over a two-week period in December 2008. USFWS data showed that, during this time, California reported the largest count of cacklers since the early 1990s (Pacific Flyway Council 2005).

In contrast to cacklers, very little banding was done with white-fronts in the past. The white-front population had remained relatively stable and there seemed little reason to expend resources in banding studies. Recently, however, there has been an increased effort to band white-fronts due the apparent increase in population. Banding data have revealed that white-fronts banded on the Y-K Delta are harvested in California, Oregon, and Texas. Also, increasing numbers have been taken from Oregon over the 2007 through 2010 hunting seasons. 


\subsection{HARVEST DATA}

Northwest Permit zone harvest data and voluntary wing and part survey data was analyzed for this thesis. Because, by law, all hunters must submit each goose taken to a check station for identification, the data is fairly detailed and accurate. Regional counts are available for each species and subspecies of goose harvested in the Northwest Permit Zone.

In Oregon, eight cacklers were recorded during the 1986 hunting season-- the first year that cacklers were recorded in the State. The numbers of harvested cacklers dramatically increased between the 1993-1994 and 1994-1995 seasons. In 1993-1994, 72 cacklers were recorded while in 1994-1995, 1, 220 cacklers were recorded.

The data seem to indicate that cacklers are continuing to shift their migration northward into Washington and British Columbia. Wing and parts survey data have shown dramatic increases in cackling geese taken in Washington. Increasing numbers of cacklers are being harvested from Olympia northward than have been noted previously (B. Reishus, ODFW, personal communication, 2010). There is even a small wintering population of cacklers near Vancouver, B.C., according to the Canadian Fish and Wildlife Service (CWS 2010). This trend to more northerly wintering areas is expected to continue, according to the 2010 wing and parts report (D. Collins, USFWS, personal communication, 2010).

White-fronted geese have historically been harvested in eastern Oregon in October during their fall migration and again in January and February on their northward migration. In recent years, however, white-fronts have been showing up in the Willamette Valley harvest. Consistent data on white-front harvest in western Oregon were not collected until 1997. In that year, 44 white-fronts were counted in the harvest; in 2008, 172 white-fronts were recorded. It appears that this trend is similar to that exhibited by cacklers in the 1980s just before the huge increases of the 1990s (table 1).

The wing and parts surveys show that there has been a significant increase in white-front harvest in all counties in Oregon with the greatest increase (45 percent) noted in Coos County on the southern Oregon coast. The parts survey coincides directly with the harvest data of the permit zone in that there were large sums of White-fronts harvested in 08/09 and still some but less in 09/10.

\subsection{AGRICULTURAL DATA}

Since the early 1900s, agriculture in the Willamette Valley has primarily centered on row crops. Between 1970 and 1980, the primary crop shifted to grass seed for lawns. Grass is particularly attractive to geese because of its high nutrient content and because geese can consume great quantities of grass with little expenditure of energy.

The primary grass types grown in the valley include fescue, perennial ryegrass, and annual ryegrass. Geese prefer annual ryegrass, which must be planted annually and, therefore, produces new shoots each year. Geese prefer the fresh shoots because they are very nutritious and easy to graze. Fescue and perennial ryegrass fields are also used by geese for the first few years after they are planted, though the new shoots of these grass varieties are tougher than those of annual rye. Usage of fescue and perennial ryegrass drops off after the second year because, by this time, the roots are more mature and harder for the geese to pull up (Flowers 2010).

By the late 1980s and through the 1990s, the acreages planted to fescue and perennial ryegrass decreased and those planted to annual ryegrass increased due to market prices caused by increased demand in Japan. This shift in crops paralleled the increase in the wintering cackler population in the valley. 
In recent years, grass prices have decreased and wheat prices have increased (Figure 15). This has resulted in some farmers changing crops from grass to winter wheat. A decade ago, only 30,000 acres of farm land in the Willamette Valley were planted to wheat; in 2010, about 250,000 acres of wheat will be harvested (Capital Press 2009).

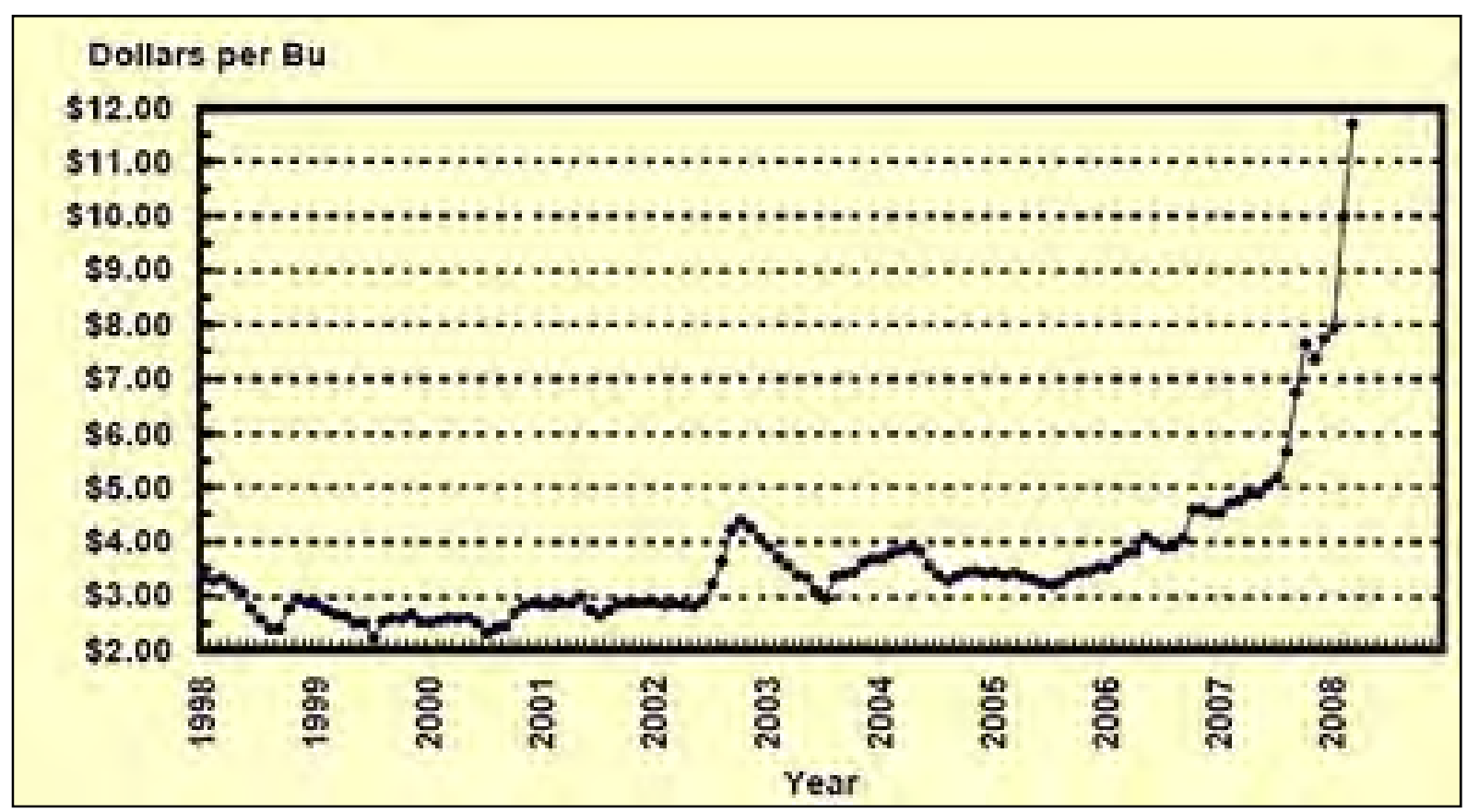

Figure 15: U.S. Wheat Prices, 1998-2009 (ODA 2009)

Winter wheat is also being targeted by geese. The crop is planted in late September and the fresh shoots appear in late October and early November-about the time when geese are arriving from Alaska. Some farmers have reported losing nearly 70 percent of their wheat crop to goose depredation. Each year, nearly a million dollars per 1,000 acres of wheat are lost due to crop damage from geese (ODA 2009). Until the grass seed market improves, it is likely that more farmers will convert to winter wheat, which will, in turn, be targeted by wintering geese, resulting in continued lost revenue. Currently, the price for annual ryegrass is about $\$ 2.25$ per bushel and wheat is $\$ 12.00$ per bushel. At $\$ 12.00$ per bushel, wheat is the most economically beneficial crop for Oregon farmers (ODA 2009).

Agriculture in the Central Valley of California has changed very little in the last 50 years. Major crops in this area include wheat and rice; the acreage planted to these crops has changed less than 10 percent in the last 25 years. The component that has changed the most, however, is the availability of water for goose habitat. Over the past 50 years, nearly 4 million acres of prime agricultural land and waterfowl habitat has been lost to urbanization (USFWS 2010). In addition, California has experienced severe drought over the past 15 years, which also has limited waterfowl habitat, especially for white-fronts.

California's population is expected to continue to grow and another 2 million acres of farm land and habitat are expected to disappear by 2030. Over this same time frame, the white-front population is expected to increase. Diminishing habitat and increased human interference may stimulate the geese to migrate to other, more suitable winter habitats. 


\subsection{WEATHER AND CLIMATE DATA}

A comparison of temperature data shows a direct correlation between the northerly migration shifts and warming temperatures. The data show that there was a nearly $1.8^{\circ} \mathrm{F}$ in California change during the primary years (1991-1997) of the cackler migration change (Table 2). During this same period, the data show that there were no other major weather occurrences that could have had an effect on goose migration patterns. Since cacklers prefer cool temperatures, they may have shifted north to more suitable temperatures (Jarvis 1996). According to a study in 1996, it was found that cacklers were sensitive to warm $\left(>65^{\circ} \mathrm{F}\right)$ and very cold conditions. Because of their small bodies they lose heat or get overheated more easily than the larger subspecies of geese (Jarvis 1996).

Table 2: Average Winter Temperatures in Oregon and California, 1986-2010 (NOAA 2010)

\begin{tabular}{|l|c|c||c|c|c|}
\hline \multirow{2}{*}{ Date } & \multicolumn{2}{|c||}{ Average Winter Temperature } & & \multicolumn{2}{c|}{ Average Winter Temperature } \\
\cline { 2 - 3 } & California & Oregon & Date & California & Oregon \\
\hline 1986 & 63.2 & 49.1 & 1999 & 65.7 & 50.4 \\
\hline 1987 & 63.7 & 49.7 & 2000 & 65.7 & 50.3 \\
\hline 1988 & 63.9 & 49.8 & 2001 & 66.1 & 51 \\
\hline 1989 & 64.4 & 50.1 & 2002 & 66.5 & 51.3 \\
\hline 1990 & 64.8 & 50.3 & 2003 & 66.8 & 51.6 \\
\hline 1991 & 64.6 & 50.4 & 2004 & 67.3 & 52.1 \\
\hline 1992 & 66.1 & 50.5 & 2005 & 66.5 & 51.4 \\
\hline 1993 & 66.4 & 51 & 2006 & 66.8 & 51.8 \\
\hline 1994 & 66.8 & 51.2 & 2007 & 66.5 & 51.5 \\
\hline 1995 & 66.6 & 51 & 2008 & 66.9 & 51.4 \\
\hline 1996 & 66.3 & 51.1 & 2009 & 67 & 52 \\
\hline 1997 & 66.4 & 51.2 & 2010 & 67.1 & 52.1 \\
\hline 1998 & 65.4 & 51.1 & & & \\
\hline
\end{tabular}

Weather data shows that for the period between 1993 and 1998, during the cacklers' northward shift, the average winter temperature in the Willamette Valley increased more than $2^{\circ} \mathrm{F}$ (Table 2). Weather in the Pacific Northwest is greatly affected by alternating conditions called "El Niño" and "La Niña.” El Niño years are characterized by the appearance in December or January of unusually warm water in the Pacific Ocean. This results in warmer, wetter winters in the Willamette Valley. La Niña sequences are characterized by colder than usual ocean water, which results in unusual weather patterns including snow on the valley floor and more unpredictable weather patterns. Both La Niña and El Niño patterns typically last a year, but can last longer. These recurring weather patterns are considered evidence that climate change is occurring (NOAA 2009).

Since 1998, average temperatures have stayed fairly stable, though the storm sequences characterizing La Niña years have caused annual winter average temperatures to drop about $1^{\circ} \mathrm{F}$. Snow packs in the Pacific Northwest have also declined on average (Table 3). 
Table 3: Three-Month-Average Snowpacks in El Niño vs. La Niña Years ( La Niña =blue and El Niño = red).

\begin{tabular}{|c|c|c|c|c|c|c|c|c|c|c|c|c|}
\hline Year & DJF & JFM & FMA & MAM & AMJ & MJJ & JJA & JAS & ASO & SON & OND & NDJ \\
\hline 1975 & -0.6 & -0.6 & -0.7 & -0.8 & -0.9 & -1.1 & -1.2 & -1.3 & -1.5 & -1.6 & -1.7 & -1.7 \\
\hline 1976 & -1.6 & -1.2 & -0.8 & -0.6 & -0.5 & -0.2 & 0.1 & 0.3 & 0.5 & 0.7 & 0.8 & 0.7 \\
\hline 1977 & 0.6 & 0.5 & 0.2 & 0.2 & 0.2 & 0.4 & 0.4 & 0.4 & 0.5 & 0.6 & 0.7 & 0.7 \\
\hline 1978 & 0.7 & 0.4 & 0.0 & -0.3 & -0.4 & -0.4 & -0.4 & -0.4 & -0.4 & -0.3 & -0.2 & -0.1 \\
\hline 1979 & -0.1 & 0.0 & 0.1 & 0.1 & 0.1 & -0.1 & 0.0 & 0.1 & 0.3 & 0.4 & 0.5 & 0.5 \\
\hline 1980 & 0.5 & 0.3 & 0.2 & 0.2 & 0.3 & 0.3 & 0.2 & 0.0 & -0.1 & -0.1 & 0.0 & -0.1 \\
\hline 1981 & -0.3 & -0.5 & -0.5 & -0.4 & -0.3 & -0.3 & -0.4 & -0.4 & -0.3 & -0.2 & -0.1 & -0.1 \\
\hline 1982 & 0.0 & 0.1 & 0.1 & 0.3 & 0.6 & 0.7 & 0.7 & 1.0 & 1.5 & 1.9 & 2.2 & 2.3 \\
\hline 1983 & 2.3 & 2.0 & 1.5 & 1.2 & 1.0 & 0.6 & 0.2 & -0.2 & -0.6 & -0.8 & -0.9 & -0.7 \\
\hline 1984 & -0.4 & -0.2 & -0.2 & -0.3 & -0.5 & -0.4 & -0.3 & -0.2 & -0.3 & -0.6 & -0.9 & -1.1 \\
\hline 1985 & -0.9 & $\begin{array}{l}-0.8 \\
\end{array}$ & -0.7 & -0.7 & -0.7 & -0.6 & -0.5 & -0.5 & -0.5 & -0.4 & -0.3 & -0.4 \\
\hline 1986 & -0.5 & -0.4 & -0.2 & -0.2 & -0.1 & 0.0 & 0.3 & 0.5 & 0.7 & 0.9 & 1.1 & 1.2 \\
\hline 1987 & 1.2 & 1.3 & 1.2 & 1.1 & 1.0 & 1.2 & 1.4 & 1.6 & 1.6 & 1.5 & 1.3 & 1.1 \\
\hline 1988 & 0.7 & 0.5 & 0.1 & -0.2 & -0.7 & -1.2 & -1.3 & -1.2 & -1.3 & -1.6 & -1.9 & -1.9 \\
\hline 1989 & -1.7 & -1.5 & -1.1 & -0.8 & -0.6 & -0.4 & -0.3 & -0.3 & -0.3 & -0.3 & -0.2 & -0.1 \\
\hline 1990 & 0.1 & 0.2 & 0.2 & 0.2 & 0.2 & 0.2 & 0.3 & 0.3 & 0.3 & 0.3 & 0.3 & 0.4 \\
\hline 1991 & 0.4 & 0.3 & 0.3 & 0.4 & 0.6 & 0.8 & 1.0 & 0.9 & 0.9 & 1.0 & 1.4 & 1.6 \\
\hline 1992 & 1.8 & 1.6 & 1.5 & 1.4 & 1.2 & 0.8 & 0.5 & 0.2 & 0.0 & -0.1 & 0.0 & 0.2 \\
\hline 1993 & 0.3 & 0.4 & 0.6 & 0.7 & 0.8 & 0.7 & 0.4 & 0.4 & 0.4 & 0.4 & 0.3 & 0.2 \\
\hline 1994 & 0.2 & 0.2 & 0.3 & 0.4 & 0.5 & 0.5 & 0.6 & 0.6 & 0.7 & 0.9 & 1.2 & 1.3 \\
\hline 1995 & 1.2 & 0.9 & 0.7 & 0.4 & 0.3 & 0.2 & 0.0 & -0.2 & -0.5 & -0.6 & -0.7 & -0.7 \\
\hline 1996 & -0.7 & -0.7 & -0.5 & -0.3 & -0.1 & -0.1 & 0.0 & -0.1 & -0.1 & -0.2 & -0.3 & -0.4 \\
\hline 1997 & -0.4 & -0.3 & 0.0 & 0.4 & 0.8 & 1.3 & 1.7 & 2.0 & 2.2 & 2.4 & 2.5 & 2.5 \\
\hline 1998 & 2.3 & 1.9 & 1.5 & 1.0 & 0.5 & 0.0 & -0.5 & -0.8 & -1.0 & -1.1 & -1.3 & -1.4 \\
\hline 1999 & -1.4 & -1.2 & -0.9 & -0.8 & -0.8 & -0.8 & -0.9 & -0.9 & -1.0 & -1.1 & -1.3 & -1.6 \\
\hline 2000 & -1.6 & -1.4 & -1.0 & -0.8 & -0.6 & -0.5 & -0.4 & -0.4 & -0.4 & -0.5 & -0.6 & -0.7 \\
\hline 2001 & -0.6 & -0.5 & -0.4 & -0.2 & -0.1 & 0.1 & 0.2 & 0.2 & 0.1 & 0.0 & -0.1 & -0.1 \\
\hline 2002 & -0.1 & 0.1 & 0.2 & 0.4 & 0.7 & 0.8 & 0.9 & 1.0 & 1.1 & 1.3 & 1.5 & 1.4 \\
\hline 2003 & 1.2 & 0.9 & 0.5 & 0.1 & -0.1 & 0.1 & 0.4 & 0.5 & 0.6 & 0.5 & 0.6 & 0.4 \\
\hline 2004 & 0.4 & 0.3 & 0.2 & 0.2 & 0.3 & 0.5 & 0.7 & 0.8 & 0.9 & $\begin{array}{l}0.8 \\
\end{array}$ & $\begin{array}{l}0.8 \\
\end{array}$ & 0.8 \\
\hline 2005 & 0.7 & 0.5 & 0.4 & 0.4 & 0.4 & 0.4 & 0.4 & 0.3 & 0.2 & -0.1 & -0.4 & -0.7 \\
\hline 2006 & -0.7 & -0.6 & -0.4 & -0.1 & 0.1 & 0.2 & 0.3 & 0.5 & 0.6 & $\begin{array}{l}0.9 \\
\end{array}$ & 1.1 & 1.1 \\
\hline 2007 & 0.8 & 0.4 & 0.1 & -0.1 & -0.1 & -0.1 & -0.1 & -0.4 & -0.7 & -1.0 & $\begin{array}{l}-1.1 \\
\end{array}$ & -1.3 \\
\hline 2008 & -1.4 & $\begin{array}{l}-1.4 \\
\end{array}$ & $\begin{array}{l}-1.1 \\
\end{array}$ & $\begin{array}{l}-0.8 \\
\end{array}$ & $\begin{array}{l}-0.6 \\
\end{array}$ & -0.4 & -0.1 & 0.0 & 0.0 & 0.0 & -0.3 & -0.6 \\
\hline 2009 & -0.8 & -0.7 & -0.5 & -0.1 & 0.2 & 0.6 & 0.7 & 0.8 & 0.9 & 1.2 & 1.5 & 1.8 \\
\hline 2010 & 1.7 & 1.5 & 1.2 & 0.8 & 0.3 & -0.2 & & & & & & \\
\hline
\end{tabular}

The average annual winter temperatures in central Washington and British Columbia have also increased (Figure 16) and the snow packs have declined. For example, British Columbia's snow pack has declined nearly 10 percent over the last 5 years (CWS 2010). This will have dramatic effects on water availability for human use and wildlife. These more extreme weather patterns are causing drought, significant storms, vegetation changes, increased wildfires, decreases in precipitation, increased evaporation, and decreases in snow pack. 


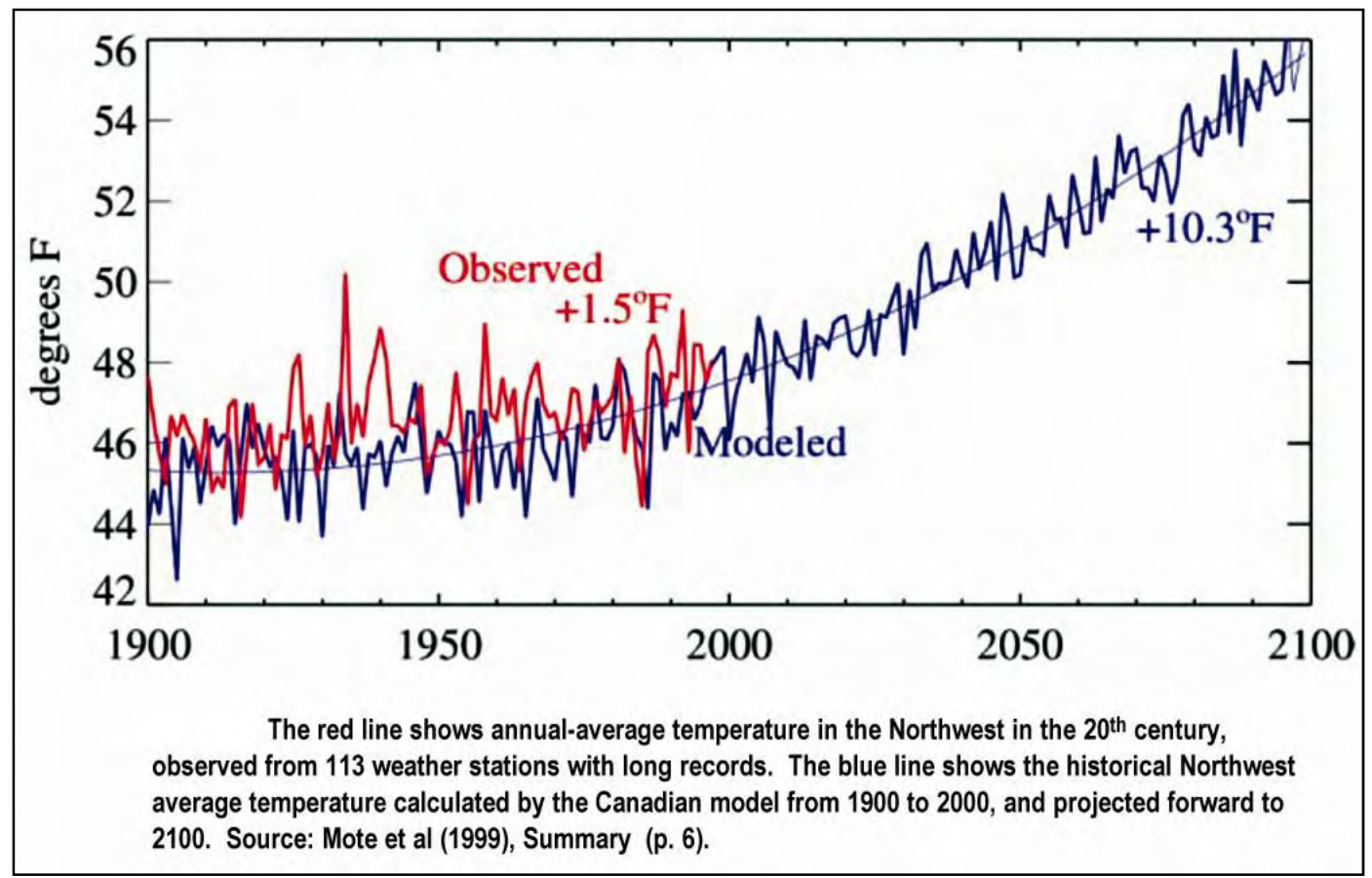

Figure 16: Average Temperatures in the Northwest, Observed and Modeled (Mote et al. 1999)

In the next 50 years, precipitation levels are projected to decrease in the southernmost regions. Conditions in California are already showing evidence of this drying trend. It is likely that continued drying will have effects on goose migrations to and through California.

During the winter storms in 2009 and 2010, cacklers have sought refuge in areas with the least amount of snow pack in Oregon. During the winter of 2008-2009, an unusually snowy winter in western Oregon and Washington, cacklers wintered at Fern Ridge Wildlife area near Eugene Oregon, which had the least amount of snow recorded in the Willamette Valley and southwest Washington at the time (Reishus 2010). Nearly 62,000 cacklers were counted on or within a 5-mile radius of the Fern Ridge Wildlife area. Some geese moved south within the valley during the severe weather; but moved back to the north after the weather warmed.

A storm during the winter of 2009-2010 dropped snow in the foothills and in the Willamette Valley. The least amount of snow was on the valley floor. During this event, Baskett Slough Wildlife Refuge near Dallas, Oregon, hosted nearly 65,000 cacklers. Because of the snow, the cacklers were pushed onto Baskett Slough, and other areas that typically contained large numbers of cacklers held very few.

During the last two winter storm periods, Southwest Washington recorded a 20 percent increase in cacklers. Ridgefield Wildlife Refuge near Ridgefield, Washington, produced the highest counts on record for cackling geese in 2007 through 2010 (USFWS 2010).

\subsection{INTERPRETATION OF AERIAL PHOTOGRAPHS}

Comparison of aerial photographs of the Y-K Delta taken in the 1970s with those taken in recent years reveal that river channels that were previously quite narrow are now up to 3 times wider. This is most likely due to de-stabilization of the permafrost soils. Erosion of thawed soils into river channels was observed several times during the June breeding season survey on the Y-K Delta. The river banks slough off, causing the river channel to widen. 


\section{CONCLUSIONS}

As stated in Section 1, the questions this thesis considers are: 1) why cackling geese and Pacific whitefronted geese are shifting their migratory patterns, 2) how the shifts are affecting the natural ecosystem and human environment, and 3) how changes in migratory patterns will affect goose management.

The data presented in Section 4 clearly show that cacklers have shifted their wintering areas northward and that white-fronts are most likely also in the process of changing their migratory behaviors. Goose population data was compared with weather data as well as with agricultural data. It appeared that the northerly wintering data correlated more closely with weather data over the same time period than with agricultural data. This was determined by analyzing the farming practices at the time of the migration shift. Since the agriculture had little change during the years in which goose migrations experienced the most change, it was concluded that agricultural practices were not a major cause of the northerly shift.

Agriculture may, however, be augmenting the shift and could play a larger part in the continuation of the northerly shift. The type and quantity of available food in California has remained stable in the last 50 years. Recently, however, there has been a shift in the Willamette Valley crops. The primary farmed crop in the Willamette Valley is now winter wheat (Section 4.4). Winter wheat is a preferred food for cacklers and white-fronts according to food behavior studies conducted by OSU (USFWS 2005). With the current favorable market for wheat and the overall long-term increase in temperature, it is likely that the preferred food source for geese will be increasingly available in Oregon and southwest Washington. This will be a large draw for cacklers and other goose species to the Willamette Valley. Geese headed to traditional wintering areas in California may stop in southwest Washington and Oregon if there is ample forage available.

Population data were then compared to weather data. This comparison revealed that, during the cacklers' shift northward, significant climate and weather changes were occurring in the Pacific Northwest and Alaska, including increased average temperatures and severe storms. Goose population data and geographic data from several sources were compared with data on increased winter temperatures. The population data - taken from field surveys, band surveys ${ }^{8}$ and wing and parts data-revealed a probable direct correlation between increased winter temperatures and the northerly shift of cackler wintering grounds. However, the same correlation with white-fronts was not obvious because data have been consistently collected over a much shorter period. It is likely, however, that white-front populations will continue to increase in Oregon due to changes on the Alaska breeding grounds as well as in the California wintering grounds.

The two species are very different in their habitat requirements and behavior and tend not to associate much with one another. Cacklers feed in dry, open fields and go to water in the afternoons. White-fronts are highly dependent on water and prefer muddy grazing conditions (J. Fischer, USFWS, personal communication, 2010). Yet even with their differences, each population appears to be abandoning their historical wintering grounds.

\footnotetext{
${ }^{8}$ Because banding of white-fronts has not been extensive or consistent, the data for this species was insufficient to conclude on the basis of this type of data alone that climate change is a cause for the birds' shift in wintering areas from California to Oregon.
} 
Climate change is thought to be the cause of habitat changes on the nesting grounds of the Y-K Delta (Section 2.1.2). As the area dries out, nesting habitat for species and subspecies dependent upon water will be reduced and the populations will either adapt, shift to new breeding grounds or be reduced or both. Currently white-fronts, which prefer drier nesting areas, are showing a positive reaction to the decrease of water levels as formerly wet habitat converts to drier uplands.

Subsistence hunters in Alaska and sport hunters in the Pacific Northwest will be affected by changes in the numbers and species comprising wintering populations. The affect may be positive because the goose population in the Y-K Delta appears to be increasing. More birds per square mile will make finding and harvesting them easier.

Increased population numbers for one species or subspecies could mean potential problems for other species or subspecies through alteration of habitat or displacement from traditional habitats. The focal species for goose management in Oregon and southwest Washington is the dusky Canada goose. The dusky Canada goose is a "less successful" subspecies that has been displaced on wintering grounds due to the increase in cacklers (Pacific Flyway 2008). If the current management approach is continued, the revised management plans would favor the dusky. This could affect the overall population levels of cacklers. Management plans must consider all pertinent species; conservation of one species at the expense of another must be avoided. As populations of species and subspecies not previously treated by the area's management plan continue to increase, a wider perspective must be adopted before the effects of changed migration patterns becomes a problem.

Retention of good quality habitat to accommodate all goose species and subspecies in western Oregon is essential to maintaining a healthy ecosystem with species diversity. The result of decreased natural habitat could be increased depredation of agricultural crops and intrusion of geese into urban settings.

Depredation caused by geese can dramatically affect a farmer's ability to sustainably farm and make a living. This is especially true with the current economy, which has increased costs to successfully raise crops. Between goose depredation and the economy, farmers struggle to keep their farms in operation. Depredation of agricultural fields can be reduced by planting refuges and other wildlife areas with crops and habitat that are attractive to wintering geese. This will help draw wintering geese away from farms.

As goose populations increase, more geese will be found in urban settings, which will present problems for wildlife managers. Geese cause damage to sports fields and golf courses, contribute to water contamination, and can cause human health risks. Funding for goose control and research into more effective techniques will need to increase.

The agencies must devise strategies to manage increasing numbers and species of geese on wintering grounds as well as the effects of geese on hunting, agriculture, and communities. In order to devise strategies, agency personnel must identify the causes of the shifts.

More research is needed to determine if, in the long term, the cackler population will be negatively impacted by the habitat changes occurring in the Y-K Delta. USFWS theorizes that the Y-K Delta will be substantially drier by 2050. If this occurs, it appears that cacklers will have more difficulty in finding suitable nesting habitat while white-fronts, which are less dependent upon water, will likely thrive. Individual goose populations may rise or fall depending upon the extent of the changes and the species' abilities to adapt to them (J. Fischer, USFWS, personal communication, 2010). Cacklers and white-fronts as well as other species and subspecies may continue to shift to new breeding and wintering areas. If cackler nesting habitat is reduced, though the northern migratory shift may continue, but the overall population may be smaller, resulting in fewer cacklers in the Willamette Valley. 
Another cause of the northerly shift in goose populations could be that water levels in California are receding. Less water limits waterfowl habitat and restricts the birds to certain areas. The increase in the white-front population combined with decreasing habitat in traditional wintering areas is most likely resulting in a shift of this species northward to the Willamette Valley in an effort to find suitable habitat and food. However, without further research, it is difficult to determine whether this population's shift is occurring because of climate change or due to a combination of factors including an increasing goose population and decreased wetlands in California.

The cacklers' current migratory shifts have dramatically affected the dusky Canada goose. As cackler numbers increase, duskies are being pushed out of their primary preferred habitats and, consequently, are moving into areas they have not previously used. In some of these areas, there are no regulations against harvesting duskies (B. Bales, personal communication, 2010). The dusky is a "species of concern" indicating that its population is already stressed, and it is possible that it will not be able to withstand increases in the cackler population and subsequent loss of habitat.

It is likely that other species and subspecies will increase in number with continued mild climate conditions. Indications are that white-fronts are beginning a northerly shift. If projected trends are accurate, there will be an overall increase in geese the next 50 years (J. Fischer, personal communication, 2010). More geese over a wider area will ensure greater hunting opportunities as well as more liberal seasons and bag limits for sport hunters in the Pacific Northwest as well as for subsistence hunters in Alaska.

If the environment continues to warm, habitat type and availability will continue to change, favoring some species over others. The management agencies must be prepared to anticipate and meet these challenges as they arise. This will require a concerted cooperative effort among state and federal agencies in terms of research, data sharing, and formulation of management plans.

Computer models are good tools for formulating management plans. Currently, the primary models deal solely with population and breeding No models focusing on the effects of climate change on waterfowl behavior currently exist. In fact, the concept of researching the effects of climate change in order to predict migration changes and other effects is quite new. The migration shifts discussed in this document were not evident before 1990. Since that time, waterfowl management has had to adapt quickly to the rapid shifts of goose populations.

Most waterfowl models in existence focus on population size or foraging and breeding behavior rather than migration. Oregon State University is currently conducting a study on goose feeding behavior. The University of Nevada is conducting a hatching study to determine the success of goslings based on hatch date and foraging behavior. The literature reviewed for this thesis did not reveal any studies that included modeling relating climate and migration; nor did any models focus on cacklers or white-fronts.

Climate change has not been recognized as an environmental concern until relatively recently. Therefore, little or no data exist which could support a model focusing on the relationship between increasing temperatures and waterfowl behavior. For example, very few wintering ground surveys have been conducted for geese.

Most agencies to date have focused on breeding ground surveys rather than wintering surveys. However, as population shift becomes more evident, management issues associated with fewer geese in some areas and more in others will rise in priority. Modeling that can predict where the changes are expected to take place and their magnitude will be invaluable to waterfowl managers in the Pacific Flyway. In the future, a migration model based on climate change may play a significant role in management of shifting populations. 
Energetics and migration length are factors that may be contributing to waterfowl migration changes. Though these issues were outside the scope of this thesis, they are worth considering in the overall picture of migration pattern change. Many scientists believe that geese may be altering their migration patterns simply because suitable food sources are available closer to the breeding grounds.

Migration is costly from the energy standpoint. The distance from the Y-K Delta to the Willamette Valley is 2,000 miles. Radio telemetry studies have shown that cacklers and white-fronts can fly non-stop to their designated wintering area. During this flight, a goose lose nearly a third of its body weight. Muscles mass and fat are lost and must be replenished immediately upon reaching the wintering grounds or the bird's winter survival is in jeopardy. If geese headed to California can find suitable feed several hundred miles further north, they will conserve energy and avoid potentially detrimental weight loss by stopping in the Willamette Valley or southwest Washington.

\subsection{OTHER EXAMPLES OF WATERFOWL MIGRATION CHANGE}

The literature reviewed revealed that two other species of goose found in the Pacific Flyway were experiencing northward migrational shifts: Black Brant and Northern Pintails. Both Sedinger and Ward (2010) and Maender (2002) concluded that the cause of the migration shift was increasing temperature. Other documents reviewed described northerly migration shifts, but did not draw clear conclusions as the reasons. All of the studies reviewed appeared to consistent with the findings of this thesis for cacklers and white-fronts.

\subsubsection{Black Brant}

Pacific black brant have traditionally wintered up and down the Pacific coast from Oregon to Baja, Mexico. Although records are sparse, it appears that fewer than 3,000 brant wintered in Alaska before 1977. Recently, however, at least 40,000 birds, nearly 30 percent of the Pacific black brant population, have begun to winter in Alaska. Sedinger and Ward (2010) state, "[T]his increase in wintering numbers of brant in Alaska coincides with a general warming of temperatures in the North Pacific and Bering Sea. " Sedinger and Ward (2010) concluded that their "study suggests that the growth in the brant population wintering on the Alaska Peninsula is linked to this same climate change..." USFWS (2010) estimates the total brant population at 138,000 birds. The population typically fluctuates between 110,000 and 165,000 birds and has been in a slow decline for nearly 40 years (Sedinger and Ward 2010). It appears, however, that the decline is not due to hunting pressures, but rather to the availability of food on their Alaskan feeding grounds.

Brant feed extensively on eelgrass. It appears that coastal environmental conditions for eelgrass in Alaska have improved with warming temperatures. Higher temperatures mean less coastal sea ice, making nutrient-rich eelgrass more accessible. "Undisturbed access to sufficient amounts of eelgrass is likely crucial to the winter survival of this species," according to Sedinger and Ward (2010). It is expected that the number of Pacific brant wintering in Alaska will increase if the climate continues to warm. There is concern, however, that, because the population of Pacific brant is slowly declining, birds wintering in Alaska could be adversely affected by severe cold snaps, which would thin the already dwindling population.

\subsubsection{Northern Pintail}

Until recently, northern pintails migrated to Mexico, southern California, and California’s Central Valley. However, starting in the mid to late 1990s "biologists noticed a significant decrease in the amount of wintering pintails in southern California. In 2002 biologists put satellite radio telemetry devices on 419 female Northern Pintails to attempt to find an explanation” (Maender 2002). By tracking the females and 
using historical distribution data, biologists found that pintails are no longer wintering in southern California, but are shifting northward.

In southern California, climate change has increased temperatures causing a decrease in wetlands due to drought (Maender 2002). This has resulted in decreased habitat in the areas that historically provided sanctuary for pintails. Water is evaporating and cover vegetation is dying as the water subsides. The scientists found that neither contaminants nor disease accounted for the disproportionate declines in wintering pintails in the southern Central Valley, but rather, the birds had been "redistributed.” Maender (2010) states that more than 80 percent of the tagged pintails "shifted each midwinter from areas in the south having less abundant habitat for food and refuge, to locales in the Sacramento Valley more favorable for their survival.”

The change each winter in pintail distribution appears to be related to loss of suitable habitat, drought conditions, and the lesser-quality habitat of agricultural lands planted to cotton in the San Joaquin Valley. The San Joaquin Valley lands do not flood in the winter in contrast to the flooded rice fields of the Sacramento Valley. The environmental shifts are directly related to climate change and its effects on habitat change according to Maender (2002). 


\section{RECOMMENDATIONS}

Analyses of observations and data have shown definite changes in wintering patterns along the Pacific Flyway. Goose data from various sources were compared to weather and temperature data as well as agricultural data. The comparison appeared to show a correlation relating to a northward shift in wintering. These types of analyses can aid agencies in altering their management programs by identifying migrational shifts and their causes. Agency plans and programs can accommodate changes that have already occurred and prepare for further changes. The following recommendations for management and further study are aimed at more completely understanding the scope and causes of migration shifts and formulating well-founded management plans for geese in the Pacific Flyway.

- Continue research to determine if climate change is causing changes in goose population numbers and behavior.

- Expand breeding ground flight surveys to include cacklers and habitat preference to learn how habitat change on the Y-K Delta is altering cackler behavior and breeding success.

- Expand radio transmitter studies and collar programs for cacklers in Oregon and Washington to verify northerly wintering shifts.

- Expand collar programs for cacklers wintering in the Willamette Valley to determine if the population is continuing to shift northward.

- Expand banding programs for white-fronted geese to gather more data about migration patterns.

- Develop models that will allow researchers and managers to correlate migration behavior with various environmental factors including climate change in order to: 1) determine which factors are causing migration changes in specific waterfowl populations and 2) allow managers to make changes to management plans in advance of rapid changes.

- Inform the public about how it can assist in collar surveys or volunteer for USFWS. This will enable USFWS to have more concrete data and give the public an opportunity gain a greater understanding of geese and goose management.

- Expand research on urban cackling geese to determine the nature and scope of their effect on the human environment and to devise management strategies.

- Research energetics in migrating geese to determine whether the shift in migration patterns has its basis in climate change.

- Increase data exchange and coordination among agencies.

- Formulate and implement plans at the city and county levels to manage growing numbers of geese in urban areas.

- Recognize and anticipate the possibility that goose populations may move into new wintering areas and formulate plans for management of those species.

- Implement low cost techniques, such as more liberal bag limits and seasons, hazing, etc., to assist agricultural landowners in decreasing goose-related crop damage. 


\section{REFERENCES}

Babcock, C.A. and C.R. Ely. 1994. Classification of vegetation communities in which geese rear broods on the Yukon-Kuskokwim Delta, Alaska. Can. J. Bot. 72: 1294-1301.

Bellrose, F. 1981. Ducks Geese and Swans of North America. Stackpole Company, Harrisburg, PA, and Wildlife Management Institute, Washington, D.C.

Canadian Wildlife Service. 2010. Weather Patterns and its Effect on Wildlife in British Columbia. Vancouver British Columbia, Canada, 2010.

Conant, B. and D. Groves. 2002. Alaska-Yukon Waterfowl Breeding Population Survey. Unpublished Report by the U.S. Fish and Wildlife Service. Juneau, Alaska. 35 pp.

Climate Impacts Group. 2010. Climate Outlook. April 2010. Web.

http://cses.washington.edu/cig/fpt/cloutlook.shtml

Eldridge, W.E. and C.P. Dau. 2002. Preliminary report to the Pacific Flyway Committee on the combined Pacific white-fronted goose surveys to estimate a breeding population index for Alaska, 1985-2002.

Report by the U.S. Fish and Wildlife Service Migratory Bird Management, Anchorage. 6 pp.

Ely, C.R. and A.X. Dzubin. 1994. Greater white-fronted goose (Anser albifrons). In The Birds of North America, No. 131 (A. Poole and F. Gill, eds.). The Academy of Natural Sciences, Philadelphia; The American Ornithologists Union, Washington, D.C.

Ely, C.R. and J.Y. Takekawa. 1996. Geographic variation in migratory behavior of greater white-fronted geese (Anser albifrons). Auk 113(4):889-901.

Ely, C.R., A.C. Fowler, T. DeMaria, M. Brice, and K. Steger. 1996. Nesting ecology of geese along the Kashunuk River, Yukon-Kuskokwim Delta, Alaska. Rept. Nat. Biol. Survey, Alaska Science Ctr., Anchorage.

Flowers, Bob. 2010. Assessing Goose Depredation on Grain Seed Yields.

http://oregonstate.edu/dept/range/gooseproject/about/acknowledgements.html. Accessed March 2010.

Gill, R. E., Jr., K.S. Bollinger, and M.R. Petersen. 1986. Timing, numbers, and habitat requirements of cackling Canada geese staging along the Alaska Peninsula in fall. Unpublished Report by the U.S. Fish and Wildlife Service. Anchorage. 51 pp.

Gill, R. E., Jr., K.S. Bollinger, and M.R. Petersen. 1986. Timing, numbers, and habitat requirements of cackling Canada geese staging along the Alaska Peninsula in fall. Unpublished Report by the U.S. Fish and Wildlife Service. 51 pp.

Hawkings, J.S. 1982. Migration and habitat relationships of geese on the eastern Copper River Delta, Alaska. M.S. Thesis. Univ. of Alaska, Fairbanks. 113 pp.

King, J.G. and C.S. Lensink. 1971. An evaluation of Alaskan habitat for migratory birds. Report by the Bureau of Sport, Fish and Wildlife. Anchorage. 46 pp. 
Lensink, C.J. 1969. The distribution of recoveries from white-fronted geese (Anser albifrons frontalis) banded in North America. Report by the Bureau of Sport, Fish and Wildlife. Bethel, Alaska. 63 pp.

Lensink, C.J. 1986. Recoveries of Alaska banded white-fronted geese in Mexico. Research Information Bull. 86-32. U.S. Fish and Wildlife Service. Anchorage. 2 pp.

Maender, G. 2002. Tracking Pintail-Duck Migration to Learn More About the Species’ Population Decline. USGS publication. Washington D.C.

Mickelson, P.G. 1975. Breeding biology of cackling geese and associated species on the YukonKuskokwim Delta, Alaska. Wildl. Monogr. 45. 35 pp.

Nelson, U.D. and H.A. Hansen. 1959. The cackling goose, its migration and management. Trans. N. Amer. Wildl. and Nat. Resour. Conf. 24:174-186.

National Oceanic and Atmospheric Administration. Website Data base for weather and climate. 2009. http://www.wrh.noaa.gov/pqr/. Accessed November 2009.

O’Neill, E.J. 1979. Fourteen years of goose populations and trends at Klamath Basin Refuges. Pages 316321 In R.L. Jarvis and J.C. Bartonek (eds.). Management and biology of Pacific Flyway geese. Oregon State Univ. Bookstores, Inc. Corvallis, OR.

Orthmeyer, D. L., J. Y. Takekawa, C. R. Ely, M. L. Wege, and W.E. Newton. 1995. Morphological differences in Pacific Coast populations of greater white-fronted geese (A. albifrons). Condor, 97:123132.

Oregon Department of Agriculture. Data base and historical records. 2009. Accessed November 2009. http://oda.state.or.us/dbs/search.lasso

Oregon Economics. Wheat Prices and Oregon. 2009. http://oregonecon.blogspot.com/2008/04/guestblogger-wheat-prices-and-oregon.html. Accessed February 2010.

Pacific Flyway Council. 1985. Pacific Flyway Data books, 1985. Compiled by USFWS, Division of Migratory Bird Management. Washington D.C.

Pacific Flyway Council. 1986. Pacific Flyway Data books, 1986. Compiled by USFWS, Division of Migratory Bird Management. Washington D.C.

Pacific Flyway Council. 1987. Pacific Flyway Data books, 1987. Compiled by USFWS, Division of Migratory Bird Management. Washington D.C.

Pacific Flyway Council. 1988. Pacific Flyway Data books, 1988. Compiled by USFWS, Division of Migratory Bird Management. Washington D.C.

Pacific Flyway Council. 1989. Pacific Flyway Data books, 1989. Compiled by USFWS, Division of Migratory Bird Management. Washington D.C.

Pacific Flyway Council. 1990. Pacific Flyway Data books, 1990. Compiled by USFWS, Division of Migratory Bird Management. Washington D.C.

Pacific Flyway Council. 1991. Pacific Flyway Data books, 1991. Compiled by USFWS, Division of Migratory Bird Management. Washington D.C. 
Pacific Flyway Council. 1992. Pacific Flyway Data books, 1992. Compiled by USFWS, Division of Migratory Bird Management. Washington D.C.

Pacific Flyway Council. 1993. Pacific Flyway Data books, 1993. Compiled by USFWS, Division of Migratory Bird Management. Washington D.C.

Pacific Flyway Council. 1994. Pacific Flyway Data books, 1994. Compiled by USFWS, Division of Migratory Bird Management. Washington D.C.

Pacific Flyway Council. 1995. Pacific Flyway Data books, 1995. Compiled by USFWS, Division of Migratory Bird Management. Washington D.C.

Pacific Flyway Council. 1996. Pacific Flyway Data books, 1996. Compiled by USFWS, Division of Migratory Bird Management. Washington D.C.

Pacific Flyway Council. 1997. Pacific Flyway Data books, 1997. Compiled by USFWS, Division of Migratory Bird Management. Washington D.C.

Pacific Flyway Council. 1998. Pacific Flyway Data books, 1998. Compiled by USFWS, Division of Migratory Bird Management. Washington D.C.

Pacific Flyway Council. 1998. Northwest Oregon/Southwest Washington goose depredation control plan. Compiled by State and Federal agencies within the Pacific Flyway.

Pacific Flyway Council. 1999a. Management Plan for the Cackling Goose. By the Subcommittee on the Cackling Canada Goose Pacific Flyway Study Committee. Washington D.C.

Pacific Flyway Council. 1999b. Pacific Flyway Data books, 1999. Compiled by USFWS, Division of Migratory Bird Management. Washington D.C.

Pacific Flyway Council. 2000. Pacific Flyway Data books, 2000. Compiled by USFWS, Division of Migratory Bird Management. Washington D.C.

Pacific Flyway Council. Pacific Flyway Data books, 2001. Compiled by USFWS, Division of Migratory Bird Management. Washington D.C.

Pacific Flyway Council. 2002. Pacific Flyway Data books, 2002. Compiled by USFWS, Division of Migratory Bird Management. Washington D.C.

Pacific Flyway Council. 2003a. Management Plan for the Pacific White-Fronted Goose. By the Subcommittee on the Pacific White-Fronted Goose Pacific Flyway Study Committee. Washington D.C.

Pacific Flyway Council. 2003b. Pacific Flyway Data books, 2003. Compiled by USFWS, Division of Migratory Bird Management. Washington D.C.

Pacific Flyway Council. 2004. Pacific Flyway Data books, 2004. Compiled by USFWS, Division of Migratory Bird Management. Washington D.C.

Pacific Flyway Council. 2005. Pacific Flyway Data books, 2005. Compiled by USFWS, Division of Migratory Bird Management. Washington D.C. 
Pacific Flyway Council. 2006. Pacific Flyway Data books, 2006. Compiled by USFWS, Division of Migratory Bird Management. Washington D.C.

Pacific Flyway Council. 2007. Pacific Flyway Data books, 2007. Compiled by USFWS, Division of Migratory Bird Management. Washington D.C.

Pacific Flyway Council. 2008a. Management Plan for the Dusky Canada Goose. 2008. Compiled by State and Federal agencies within the Pacific Flyway.

Pacific Flyway Council. 2008b. Pacific Flyway Data books, 2008. Compiled by USFWS, Division of Migratory Bird Management. Washington D.C.

Pacific Flyway Council. 2009. Pacific Flyway Data books, 2009. Compiled by USFWS, Division of Migratory Bird Management. Washington D.C.

Pacific Flyway Council. 2010. Pacific Flyway Data books. 2010. Compiled by USFWS, Division of Migratory Bird Management. Washington D.C.

Palmer, J.M. 1976. Handbook of North American Birds. Vol. 2, Pt. 1. Yale Univ. Press, New Haven \& London. 521 pp.

Pamplin, W.L., Jr. 1986. Cooperative efforts to halt population declines of geese nesting on Alaska's Yukon-Kuskokwim Delta. Trans. N. Amer. Wildl. Nat. Resour. Conf. 51: 487-506.

Raveling, D.G. 1979. The annual energy cycle of the cackling Canada goose. Pages 81-93 in R.L. Jarvis and J.C. Bartonek (eds). Management and biology of Pacific Flyway geese. OSU Bookstores, Inc. Corvallis, OR.

Raveling, D.G. 1983. An analysis of the decline of the cackling goose (Branta Canadensis minima) population based on banding data. Unpublished Report to Calif. Dept. of Fish and Game, Sacramento. Univ. of Calif., Davis

Raveling, D.G. 1984. Geese and hunters of Alaska YKD: Management problems and political dilemmas. Trans. N. Amer. Wildl. Nat. Res. Conf. 49:555-575.

Sedinger, J.S. 1988. Foraging behavior of cackling Canada goose goslings: implications for the roles of food availability and processing rate. Oecologia 75: 119-124.

Sedinger, J.S. and K.S. Bollinger. 1987. Autumn staging of cackling Canada geese on the Alaska Peninsula. Wildfowl 38: 13-18.

Sedinger, J.S. and D.G. Raveling. 1984. Dietary selectivity in relation to availability and quality of food for goslings of cackling Canada geese. Auk 101: 295-306.

Sedinger, J.S. and D. A. Ward. 2010. Changing Climate, Changing Patterns: An Occasional Series on the Impacts of Warming Temperatures. Field of Ecology. University of Nevada.

Sterne, C. 2010. Climate Change. http://alaska.fws.gov/climate/index.htm. Accessed February _10_, 2010.

Timm, D.E. 1982. Some observations of spring migratory waterfowl during 1982. Rep. Alaska Dept. of Fish and Game, Anchorage. 
Timm and C. Dau. 1979. Productivity, mortality, distribution and population status of Pacific Flyway white-fronted geese. Pages 280-298 in R.L. Jarvis and J.C. Bartonek, eds. Management and biology of Pacific Flyway geese. Oregon State Univ. Bookstores, Inc. Corvallis.

University of California, 2010. A Stylized history of California Agriculture from 1769-2000. Web. January 2010. http://giannini.ucop.edu/pdfs/giannini04-1b.pdf Accessed: February 2010.

United States Fish and Wildlife Service. 2010. Data base for waterfowl studies in the Pacific Flyway. Portland, OR Office.

United States Global Research Program. 2010. U.S. National Assessment of the Potential Consequences of Climate Variability and Change Educational Resources Regional Paper: Pacific Northwest. February 16, 2009.

Warren, K.E. 2007. Identification Field Guide to Geese of the Willamette Valley and Lower Columbia River. Prepared for ODFW and Washington Department of Fish and Wildlife. Salem, OR. 


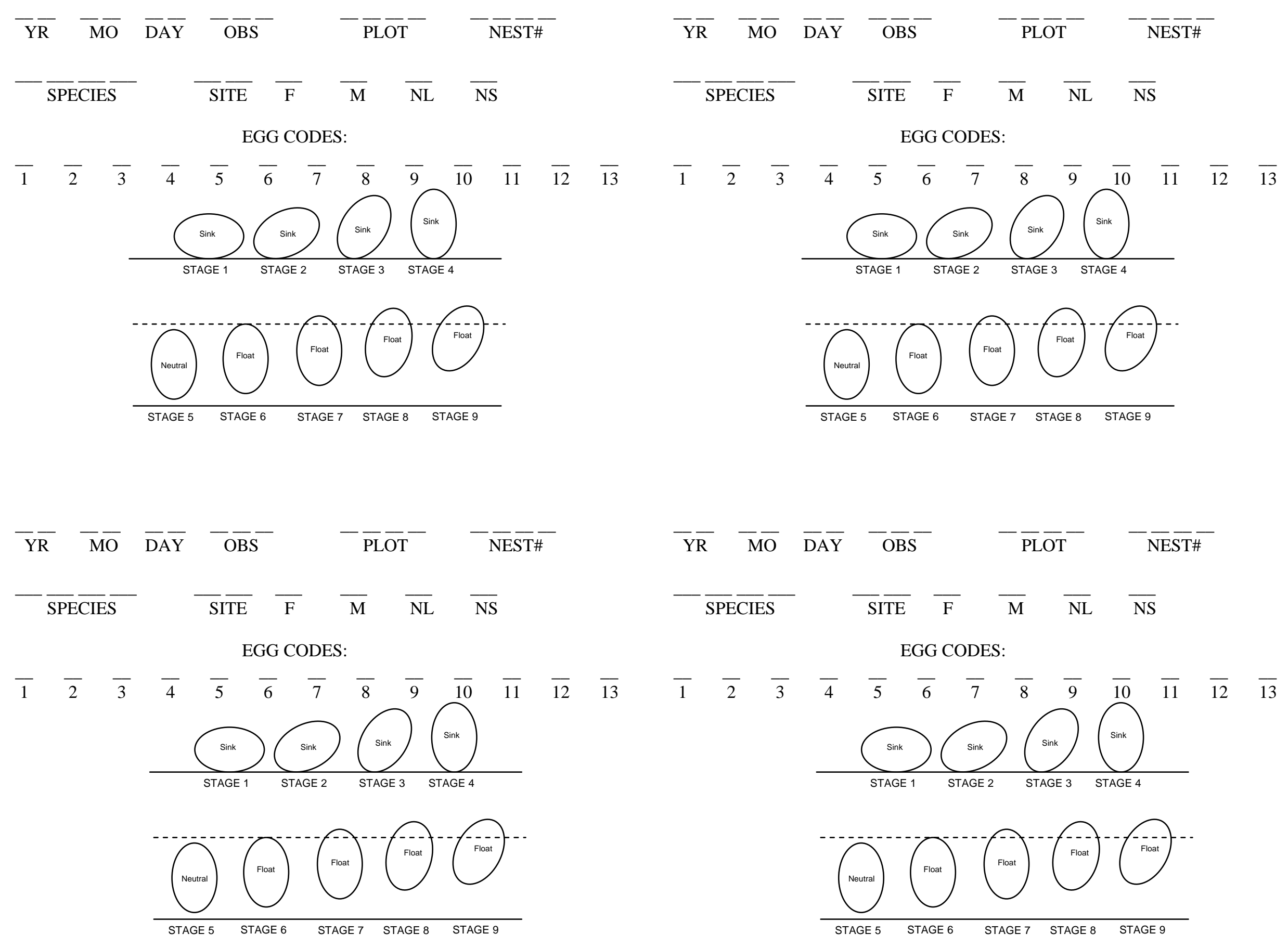



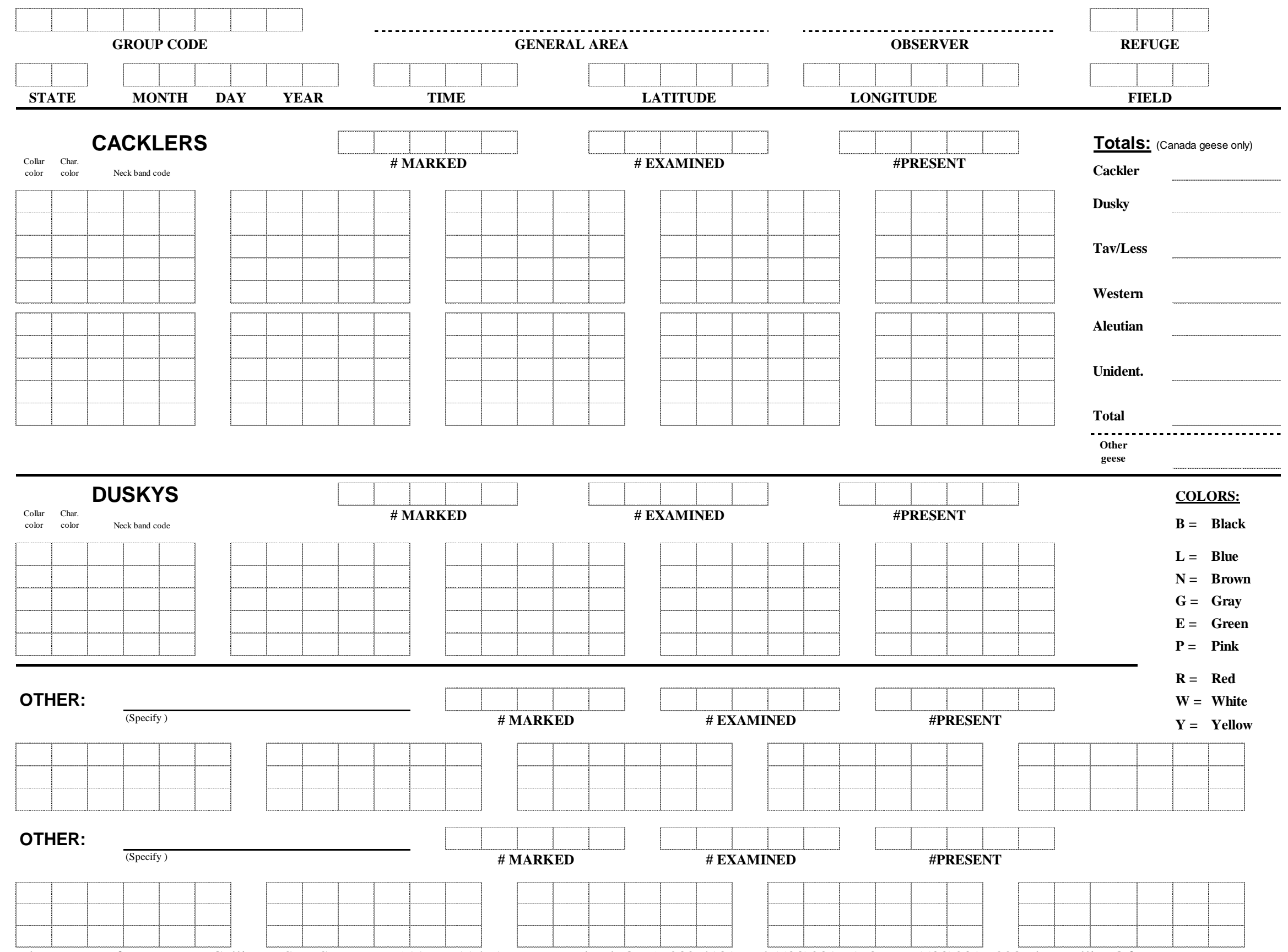

Please return forms to Dan Collins, USFWS-DMBM, 911 NE 11th Avenue, Portland, OR 97232-4181. Tel:(503)231-6163, Fax:(503)231-6228, dan_collins@fws.gov 
Appendix A3. Band Data Request Form

[NOTE - THIS TABLE IS 2 PAGES]

\begin{tabular}{|c|c|}
\hline $\begin{array}{l}\text { When requesting a BANDING data pull, } \\
\text { here are the fields that can be included }\end{array}$ & $\begin{array}{l}\text { When requesting an ENCOUNTER data } \\
\text { pull, here are the fields that can be } \\
\text { included }\end{array}$ \\
\hline AGE CODE & B AGE CODE \\
\hline AREA CODE & B AREA CODE \\
\hline BAND EVENT DATE & B BAND ID \\
\hline BAND ID & B BAND SIZE CODE \\
\hline BAND SIZE CODE & B BAND STATUS CODE \\
\hline BAND STATUS CODE & B BAND TYPE CODE \\
\hline BAND TYPE CODE & B BIRD STATUS \\
\hline BANDING DAY & B COMMENTS \\
\hline BANDING MONTH & B COORD. PRECISION \\
\hline BANDING YEAR & B DIRECTION CODE \\
\hline BIRD STATUS & B EXTRA INFO CODE \\
\hline COMMENTS & B FLYWAY CODE \\
\hline COORD. PRECISION & B HOW AGED CODE \\
\hline DIRECTION CODE & B HOW SEXED CODE \\
\hline EXTRA INFO CODE & B LAT \\
\hline FLYWAY CODE & B LAT FLOAT \\
\hline HOW AGED CODE & B LON \\
\hline HOW SEXED CODE & B LON FLOAT \\
\hline LAT & B MARKER TYPE \\
\hline LAT FLOAT & B PERMIT NUMBER \\
\hline $\mathrm{LON}$ & B REMARKS \\
\hline LON FLOAT & B REWARD BAND NUM \\
\hline MARKER TYPE & B SEX CODE \\
\hline OTHER BANDS & B SPECIES ID \\
\hline PERMIT NUMBER & BANDING DATE \\
\hline REMARKS & BANDING DAY \\
\hline REWARD BAND NUM & BANDING MONTH \\
\hline SEX CODE & BANDING YEAR \\
\hline \multirow[t]{10}{*}{ SPECIES ID } & E AREA CODE \\
\hline & E CERTIFICATE FLAG \\
\hline & E CERTIFICATE LANGUAGE \\
\hline & E COMMENTS \\
\hline & E COORD. PRECISION \\
\hline & E COUNTRY CODE \\
\hline & E CREATE DATE \\
\hline & E CREATE MONTH \\
\hline & E CREATE YEAR \\
\hline & E DIRECTION CODE \\
\hline
\end{tabular}




\begin{tabular}{|c|c|}
\hline $\begin{array}{l}\text { When requesting a BANDING data pull, } \\
\text { here are the fields that can be included }\end{array}$ & $\begin{array}{l}\text { When requesting an ENCOUNTER data } \\
\text { pull, here are the fields that can be } \\
\text { included }\end{array}$ \\
\hline & E DIRECTION1 \\
\hline & E DIRECTION2 \\
\hline & E ENC COUNTY ORIGINAL \\
\hline & E FLYWAY CODE \\
\hline & E HOW OBTAINED CODE \\
\hline & E HOW OBTAINED DESC \\
\hline & E LAT \\
\hline & E LAT FLOAT \\
\hline & E LOCATION DESCRIPTION \\
\hline & E LON \\
\hline & E LON FLOAT \\
\hline & E MARKER CODE COLOR ID \\
\hline & E MARKER COLOR ID \\
\hline & E MARKER DESC \\
\hline & E MARKER TYPE \\
\hline & E MARKER TYPE CODE \\
\hline & E MILES1 \\
\hline & E MILES2 \\
\hline & E PLACE NAME \\
\hline & E PRESENT CONDITION CODE \\
\hline & E REMARKS \\
\hline & E SPECIES NAME \\
\hline & E STATE CODE \\
\hline & E WHO OBTAINED CODE \\
\hline & E WHY REPORTED CODE \\
\hline & ENCOUNTER DATE \\
\hline & ENCOUNTER DAY \\
\hline & ENCOUNTER MONTH \\
\hline & ENCOUNTER YEAR \\
\hline & HSS \\
\hline & OTHER BANDS \\
\hline & \\
\hline
\end{tabular}


Appendix B. Washington Permit Zone Harvest Data

Canada Goose Subspecies

\begin{tabular}{lcccccccc}
\hline Season & Cackler & Dusky & Taverner & Lesser & Western & Vancouver & Other & Total \\
\hline $1984-85$ & 0 & 37 & 63 & 0 & 20 & 0 & 0 & 120 \\
$1985-86$ & 11 & 66 & 113 & 116 & 67 & 0 & 25 & 398 \\
$1986-87$ & 8 & 36 & 172 & 51 & 241 & 0 & 0 & 508 \\
$1987-88$ & 7 & 45 & 478 & 225 & 224 & 4 & 35 & 1,018 \\
$1988-89$ & 17 & 43 & 617 & 136 & 763 & 0 & 7 & 1,583 \\
$1989-90$ & 37 & 52 & 455 & 92 & 391 & 9 & 0 & 1,036 \\
$1990-91$ & 28 & 65 & 555 & 165 & 383 & 20 & 3 & 1,219 \\
$1991-92$ & 39 & 88 & 675 & 295 & 483 & 14 & 15 & 1,609 \\
$1992-93$ & 84 & 91 & 1,340 & 270 & 722 & 25 & 2 & 2,534 \\
$1993-94$ & 93 & 90 & 944 & 299 & 697 & 8 & 4 & 2,135 \\
$1994-95$ & 422 & 77 & 1,011 & 246 & 704 & 31 & 6 & 2,497 \\
$1995-96$ & 334 & 59 & 862 & 144 & 536 & 12 & 1 & 1,948 \\
$1996-97$ & 1,030 & 35 & 1,705 & 475 & 932 & 18 & 3 & 4,198 \\
$1997-98$ & 1,311 & 58 & 2,197 & 392 & 742 & 33 & 5 & 4,738 \\
$1998-99$ & 1,820 & 46 & 1,877 & 306 & 833 & 34 & 9 & 4,925 \\
Avg. 94-98 & 983 & 55 & 1,530 & 313 & 749 & 26 & 5 & 3,661
\end{tabular}


Appendix C1. Average Temperature Data for Willamette Valley by Month 1980-Present

\begin{tabular}{|c|c|c|c|c|c|c|c|c|c|c|c|c|c|c|c|c|c|c|c|c|c|c|c|c|c|c|c|c|c|c|c|c|c|}
\hline 980 & lan. & High & 55 & 51 & 43 & 42 & 46 & 39 & 37 & 45 & 44 & 35 & 54 & 57 & 55 & 50 & 46 & 51 & 46 & 41 & 46 & 42 & 48 & 49 & 47 & 46 & 48 & 34 & 32 & 30 & 32 & 34 & \\
\hline 1980 & Jan. & Low & 41 & 38 & 34 & 38 & 24 & 21 & 21 & 37 & 33 & 28 & 25 & 41 & 39 & 35 & 31 & 42 & 25 & 23 & 26 & 23 & 25 & 26 & 25 & 22 & 31 & 19 & 15 & 13 & 11 & 8 & 25 \\
\hline 1980 & Feb. & High & 53 & 53 & 59 & 50 & 52 & 55 & 52 & 53 & 50 & 52 & 52 & 51 & 46 & 38 & 40 & 45 & 43 & 55 & 54 & 53 & 48 & 49 & 55 & 58 & 48 & 59 & 59 & 58 & 56 & - & \\
\hline 880 & Feb. & Low & 32 & 41 & 39 & 30 & 36 & 40 & 32 & 25 & 26 & 31 & 28 & 22 & 25 & 31 & 31 & 33 & 37 & 39 & 40 & 36 & 29 & 32 & 38 & 42 & 43 & 48 & 50 & 38 & 32 & - & \\
\hline 980 & Mar. & High & 33 & 63 & 55 & 56 & 48 & 53 & 55 & 56 & 57 & 52 & 48 & 48 & 49 & 48 & 45 & 53 & 52 & 53 & 54 & 52 & 55 & 55 & 53 & 53 & 60 & 53 & 55 & 59 & 52 & 54 & \\
\hline 980 & Mar. & Low & 35 & 43 & 44 & 44 & 39 & 36 & 33 & 34 & 31 & 38 & 37 & 37 & 37 & 36 & 34 & 36 & 38 & 34 & 43 & 38 & 33 & 36 & 29 & 30 & 31 & 36 & 33 & 33 & 35 & 32 & \\
\hline 1980 & Apr. & High & 54 & 62 & 57 & 60 & 56 & 50 & 53 & 57 & 57 & 58 & 72 & 76 & 75 & 57 & 61 & 72 & 62 & 70 & 63 & 53 & 58 & 61 & 66 & 60 & 67 & 73 & 78 & 64 & 60 & 68 & \\
\hline 80 & Apr. & LOW & $2 y$ & 27 & 21 & 30 & 31 & 35 & 34 & 47 & 41 & 35 & 29 & 35 & 40 & 44 & 42 & 34 & 40 & 40 & 50 & 47 & 45 & 39 & 45 & 38 & 37 & 47 & 44 & 44 & 40 & 32 & \\
\hline 880 & May. & High & 75 & 63 & 73 & 73 & 66 & 63 & 68 & 59 & 58 & 56 & 60 & 62 & 59 & 62 & 62 & 67 & 74 & 74 & 72 & 73 & 62 & 61 & 59 & 60 & 57 & 55 & 64 & 69 & 68 & 67 & \\
\hline 980 & May. & Low & 38 & 40 & 33 & 43 & 45 & 39 & 33 & 43 & 46 & 46 & 51 & 50 & 49 & 47 & 39 & 32 & 38 & 44 & 41 & 43 & 40 & 41 & 40 & 37 & 47 & 47 & 44 & 45 & 43 & 50 & \\
\hline 1980 & Jun. & High & 62 & 57 & 63 & 69 & 64 & 64 & 67 & 73 & 67 & 68 & 65 & 66 & 55 & 63 & 72 & 64 & 71 & 73 & 78 & 68 & 69 & 72 & 71 & 66 & 65 & 68 & 73 & 75 & 71 & 79 & \\
\hline 980 & Jun. & Low & 43 & 45 & 45 & 39 & 42 & 48 & 51 & 54 & 46 & 51 & 52 & 51 & 52 & 52 & 51 & 48 & 47 & 44 & 44 & 47 & 44 & 48 & 50 & 52 & 43 & 40 & 51 & 48 & 45 & 40 & \\
\hline 980 & Jul. & Hign & 83 & 71 & 60 & 66 & 70 & 79 & 87 & 79 & 70 & 78 & 75 & 76 & 82 & 74 & 84 & 80 & 80 & 84 & 81 & 89 & 101 & 84 & 80 & 81 & 86 & 91 & 96 & 93 & 86 & 86 & \\
\hline 1980 & Jul. & Low & 43 & 45 & 54 & 54 & 53 & 44 & 48 & 49 & 50 & 47 & 45 & 49 & 44 & 51 & 49 & 50 & 45 & 51 & 47 & 60 & 58 & 56 & 56 & 47 & 47 & 49 & 51 & 52 & 46 & 46 & \\
\hline 1980 & Aug. & High & 83 & 75 & 78 & 83 & 73 & 79 & 88 & 83 & 92 & 94 & 84 & 80 & 77 & 76 & 77 & 80 & 81 & 74 & 83 & 80 & 77 & 77 & 82 & 76 & 85 & 79 & 71 & 73 & 76 & 66 & 4 \\
\hline 980 & Aug. & Low & 43 & 54 & 55 & 42 & 55 & 4 & 44 & 48 & 47 & 51 & 46 & 48 & 54 & 45 & 42 & 56 & 48 & 50 & 42 & 45 & 39 & 41 & 43 & 49 & 41 & 40 & 47 & 36 & 40 & 50 & 51 \\
\hline 980 & Sep. & High & 30 & 72 & 71 & 84 & 87 & 81 & 75 & 88 & 94 & 90 & 80 & 73 & 61 & 15 & 84 & 86 & 83 & 63 & 65 & 68 & 10 & 14 & 18 & 18 & 89 & 82 & $6 r$ & 77 & 82 & 75 & \\
\hline 1980 & Sep. & Low & 41 & 50 & 42 & 41 & 44 & 47 & 51 & 43 & 52 & 50 & 47 & 45 & 45 & 46 & 38 & 41 & 47 & 50 & 58 & 52 & 45 & 40 & 48 & 50 & 45 & 48 & 48 & 51 & 47 & 55 & \\
\hline 1980 & Oct. & High & 83 & 92 & 86 & 82 & 89 & 83 & 83 & 72 & 79 & 70 & 58 & 61 & 58 & 59 & 60 & 59 & 61 & 61 & 64 & 61 & 61 & 67 & 66 & 56 & 58 & 53 & 62 & 62 & 59 & 54 & \\
\hline 980 & Oct. & Low & 44 & 47 & 47 & 40 & 45 & 45 & 45 & 47 & 40 & 41 & 38 & 51 & 48 & 45 & 38 & 31 & 35 & 36 & 38 & 43 & 33 & 28 & 31 & 40 & 41 & 44 & 38 & 31 & 32 & 38 & 46 \\
\hline 980 & Nov. & High & 61 & 65 & 65 & 57 & 65 & 6 & 62 & 58 & 57 & 48 & 50 & 5 & 48 & 52 & 54 & 44 & 54 & 60 & 60 & 56 & 55 & 45 & 0 & 3 & 54 & 49 & 59 & 56 & 56 & 47 & \\
\hline 1980 & Nov. & Low & 50 & 43 & 51 & 48 & 51 & 49 & 53 & 47 & 38 & 32 & 30 & 28 & 24 & 33 & 38 & 31 & 42 & 44 & 39 & 45 & 34 & 30 & 36 & 35 & 41 & 41 & 40 & 42 & 40 & 31 & \\
\hline 1980 & Dec. & High & 47 & 56 & 53 & 40 & 43 & 40 & 36 & 38 & 33 & 45 & 54 & 47 & 43 & 56 & 54 & 49 & 39 & 39 & 42 & 49 & 62 & 55 & 50 & 59 & 62 & 60 & 61 & 47 & 53 & 66 & \\
\hline 980 & Dec. & LC & 40 & 41 & 35 & 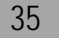 & 35 & 32 & 2 & 20 & 15 & 29 & 27 & 28 & 27 & 35 & 30 & 33 & 35 & 37 & 38 & 40 & 42 & 46 & 36 & 45 & 58 & 5 & 41 & 37 & 39 & 48 & 36 \\
\hline 1981 & Jan. & High & 54 & 50 & 47 & 51 & 54 & 5 & 47 & 45 & $4 \varepsilon$ & 48 & 47 & 4 & 48 & 47 & 49 & 44 & 45 & 55 & 50 & 50 & 52 & 53 & 52 & 51 & 49 & 44 & 46 & 43 & 49 & 49 & 47 \\
\hline 1981 & Jan. & Low & 33 & 36 & 35 & 32 & 29 & 33 & 32 & 35 & 33 & 25 & 25 & 23 & 23 & 24 & 26 & 28 & 31 & 36 & 35 & 29 & 46 & 46 & 36 & 36 & 34 & 33 & 35 & 32 & 30 & 32 & 30 \\
\hline 1981 & Feb. & High & 40 & 36 & 47 & 39 & 44 & 46 & 44 & 36 & $4 \varepsilon$ & 43 & 54 & 64 & 57 & 59 & 56 & 61 & 56 & 61 & 62 & 54 & 5 & 51 & 59 & 1 & 48 & 47 & 9 & 65 & - & - & \\
\hline 981 & Feb. & & 30 & 34 & 28 & 25 & 31 & 23 & 27 & 30 & 32 & 29 & 31 & 44 & 47 & 49 & 48 & 49 & 45 & 49 & 38 & 35 & 31 & 29 & 35 & 35 & 28 & 29 & 33 & 27 & - & & \\
\hline 1981 & Mar. & $\mathrm{H}$ & 65 & 63 & 50 & 51 & 51 & 57 & 56 & 58 & 66 & 60 & 6 & 6 & 60 & 61 & 53 & 58 & 57 & 59 & 56 & 9 & 55 & 60 & 8 & 58 & 60 & 9 & 59 & 58 & 52 & 51 & 49 \\
\hline 1981 & Mar. & Low & 29 & 29 & 39 & 33 & 25 & 24 & 37 & 35 & 29 & 36 & 41 & 35 & 35 & 35 & 43 & 32 & 25 & 30 & 33 & 30 & 33 & 44 & 38 & 34 & 44 & 45 & 44 & 39 & 41 & 41 & 41 \\
\hline 1981 & Apr. & High & 56 & 50 & 55 & 62 & 57 & 54 & 56 & 50 & 57 & 54 & 54 & b/ & 63 & 73 & 64 & 64 & 68 & 76 & b/ & 60 & 60 & 10 & 67 & 59 & 60 & 62 & 56 & 75 & 80 & 79 & \\
\hline 1981 & Apr. & L & 36 & 33 & 36 & $4 C$ & 36 & 34 & 39 & 40 & 32 & 36 & 39 & 32 & 28 & 33 & 43 & 38 & 33 & 37 & 46 & 44 & 46 & 51 & 47 & 36 & 33 & 39 & 40 & 51 & 48 & $5<$ & \\
\hline 1981 & ay. & $\mathrm{H}$ & 63 & 60 & 57 & 57 & 56 & 57 & 61 & 6 & 65 & 67 & 66 & 72 & 73 & 6 & 58 & 63 & 62 & 60 & 0 & 61 & 60 & 73 & 76 & 68 & 68 & 70 & 73 & 81 & 74 & 69 & 72 \\
\hline 1981 & May. & Low & 38 & 41 & 38 & 36 & 42 & 41 & 40 & 40 & 45 & 42 & 39 & 34 & 51 & 47 & 40 & 42 & 50 & 46 & 40 & 50 & 50 & 48 & 50 & 56 & 46 & 42 & 40 & 42 & 50 & 47 & 40 \\
\hline 1981 & Jun. & High & 71 & 72 & 72 & 70 & 71 & 65 & 59 & 62 & 66 & 67 & 70 & 64 & 64 & 68 & 78 & 65 & 68 & 65 & 71 & 67 & 71 & 67 & 71 & 83 & 83 & 72 & 72 & 78 & 85 & 70 & \\
\hline 981 & Jun. & LoM & 41 & 50 & 5 & 54 & 49 & 44 & 46 & 54 & 53 & 45 & 38 & $4 \varepsilon$ & 47 & 42 & 40 & 47 & 4 & 54 & 55 & 51 & 52 & 50 & 51 & 46 & 48 & 7 & 40 & 16 & 47 & 53 & \\
\hline 1981 & Jul. & rily & 75 & 91 & 9 & 90 & 79 & 6 & 68 & 77 & 71 & 71 & 74 & 7 & 7 & 8 & 8 & 86 & & 7 & 80 & & 7 & & & 7 & & 6 & & I & 76 & & \\
\hline 1981 & Jul. & Low & 46 & 52 & 51 & 53 & 56 & 50 & 46 & 43 & 48 & 44 & 41 & 45 & 52 & 51 & 48 & 49 & 50 & 50 & 50 & 52 & 55 & 55 & 57 & 56 & 55 & 54 & 60 & 50 & 49 & 45 & \\
\hline 1981 & Aug. & High & 85 & 68 & 78 & 81 & 87 & 98 & 104 & 106 & 108 & 107 & 99 & 90 & 86 & 92 & 82 & 86 & 94 & 91 & 67 & 72 & 81 & 87 & 88 & 78 & 77 & 79 & 80 & 85 & 72 & 77 & 32 \\
\hline 981 & Aug. & Low & 48 & 50 & 54 & 55 & 48 & 5 & 55 & 58 & 63 & 62 & 58 & 54 & $\zeta 1$ & 54 & 52 & 48 & 52 & 54 & 54 & 49 & 46 & 45 & $5 \perp$ & 57 & 48 & 44 & 41 & 46 & 47 & 49 & 44 \\
\hline 81 & sep. & Hilgr & 76 & 18 & 81 & 76 & 79 & 95 & 99 & 90 & $l \perp$ & 80 & 86 & 84 & 84 & 89 & 96 & 86 & OL & 81 & 8 & $0 /$ & 64 & 64 & 01 & $6 /$ & 0 & 59 & 72 & 36 & 6 & 0 & \\
\hline 981 & Sep. & Low & 53 & 45 & 44 & 44 & 46 & 49 & 50 & 48 & 49 & 59 & 48 & 45 & 44 & 42 & 44 & 48 & 50 & 50 & 48 & $5 \perp$ & 47 & 44 & 39 & 41 & 43 & 50 & 51 & 50 & 44 & 40 & \\
\hline
\end{tabular}


Appendix C1. Average Temperature Data for Willamette Valley by Month 1980-Present

$\begin{array}{cccccccccccccccccccccccccccccccc}\mathbf{1} & \mathbf{2} & \mathbf{3} & \mathbf{4} & \mathbf{5} & \mathbf{6} & \mathbf{7} & \mathbf{8} & \mathbf{9} & \mathbf{1 0} & \mathbf{1 1} & \mathbf{1 2} & \mathbf{1 3} & \mathbf{1 4} & \mathbf{1 5} & \mathbf{1 6} & \mathbf{1 7} & \mathbf{1 8} & \mathbf{1 9} & \mathbf{2 0} & \mathbf{2 1} & \mathbf{2 2} & \mathbf{2 3} & \mathbf{2 4} & \mathbf{2 5} & \mathbf{2 6} & \mathbf{2 7} & \mathbf{2 8} & \mathbf{2 9} & \mathbf{3 0} & \mathbf{3 1} \\ & 74 & 66 & 62 & 64 & 61 & 63 & 64 & 55 & 59 & 62 & 56 & 56 & 61 & 63 & 65 & 66 & 66 & 70 & 67 & 58 & 69 & 70 & 62 & 66 & 58 & 56 & 64 & 54 & 48 & 55 & 67 \\ & & & & & & & & & & \end{array}$ 1981 Oct. $\quad$ Low 39 \begin{tabular}{llllllllllllllllllllllllllllllllllll} 
& 39 & 40 & 39 & 38 & 49 & 48 & 48 & 44 & 44 & 36 & 30 & 29 & 29 & 32 & 34 & 39 & 36 & 39 & 36 & 30 & 28 & 29 & 34 & 37 & 51 & 50 & 45 & 42 & 42 & 39 \\
\hline
\end{tabular}

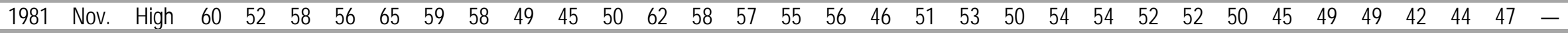
1981 Nov. Low $38 \begin{array}{lllllllllllllllllllllllllllllll} & 31 & 33 & 26 & 24 & 30 & 33 & 38 & 39 & 40 & 46 & 43 & 44 & 41 & 41 & 38 & 43 & 37 & 38 & 47 & 45 & 42 & 40 & 35 & 35 & 28 & 25 & 17 & 28 & 39 & -\end{array}$

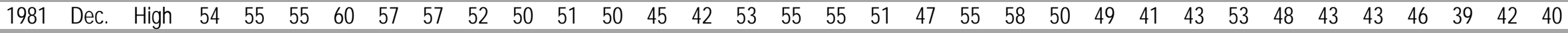
1981 Dec. Low $47 \begin{array}{llllllllllllllllllllllllllllllllll}32 & 28 & 45 & 47 & 47 & 39 & 39 & 44 & 35 & 30 & 32 & 40 & 37 & 42 & 31 & 31 & 41 & 39 & 40 & 30 & 32 & 34 & 41 & 38 & 35 & 36 & 29 & 25 & 25 & 30\end{array}$

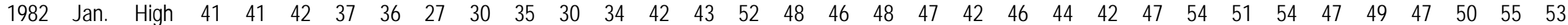

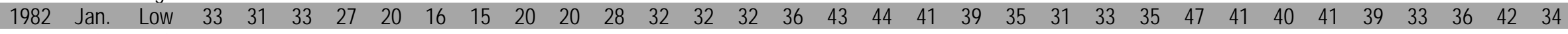

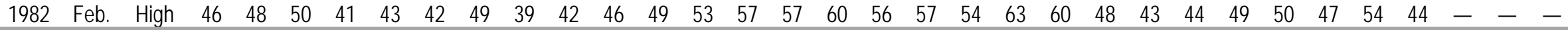

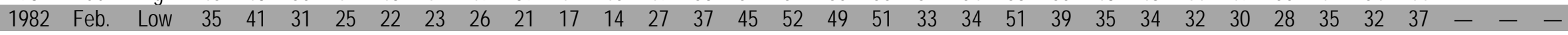

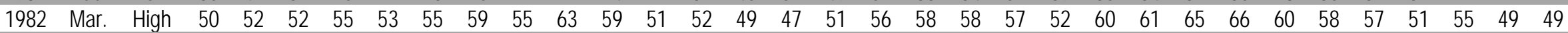
1982 Mar. Low $39 \begin{array}{llllllllllllllllllllllllllllllllllll} & 42 & 43 & 31 & 29 & 25 & 26 & 36 & 47 & 47 & 32 & 32 & 45 & 30 & 31 & 29 & 24 & 26 & 29 & 33 & 26 & 27 & 28 & 30 & 35 & 42 & 40 & 37 & 34 & 36 & 32\end{array}$

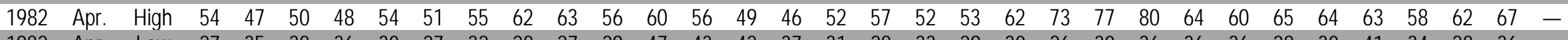
1982 Apr. Low $27 \begin{array}{lllllllllllllllllllllllllllllll}35 & 38 & 36 & 30 & 27 & 32 & 28 & 27 & 29 & 47 & 43 & 42 & 37 & 31 & 28 & 33 & 29 & 30 & 26 & 30 & 36 & 36 & 36 & 28 & 30 & 41 & 34 & 28 & 36 & -\end{array}$ 1982 May. High 65 \begin{tabular}{lllllllllllllllllllllllllllllll}
61 & 59 & 60 & 71 & 75 & 62 & 56 & 55 & 58 & 67 & 67 & 69 & 70 & 71 & 73 & 61 & 60 & 69 & 74 & 75 & 69 & 76 & 89 & 75 & 62 & 68 & 77 & 81 & 84 & 66 \\
\hline
\end{tabular}

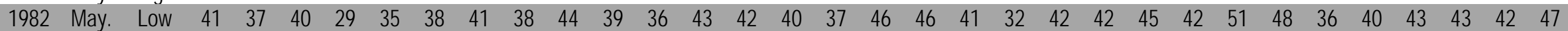
1982 Jun. $\quad$ High $64 \begin{array}{llllllllllllllllllllllllllllllllllll}67 & 66 & 64 & 65 & 66 & 73 & 81 & 90 & 92 & 68 & 58 & 69 & 72 & 83 & 90 & 94 & 102 & 97 & 87 & 79 & 87 & 93 & 89 & 83 & 75 & 70 & 68 & 77 & 74 & -\end{array}$

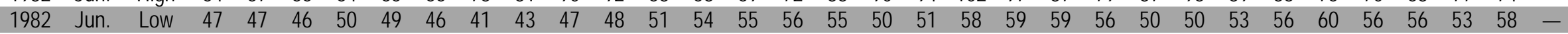

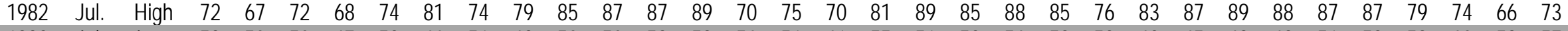
$\begin{array}{llllllllllllllllllllllllllllllllllllllll}1982 & \text { Jul. } & \text { Low } & 58 & 50 & 50 & 47 & 52 & 46 & 51 & 48 & 50 & 50 & 53 & 53 & 56 & 51 & 41 & 55 & 51 & 52 & 56 & 59 & 52 & 42 & 45 & 48 & 49 & 51 & 53 & 59 & 60 & 58 & 57 \\ 1982 & \text { Aug. } & & 7 & 71 & 75 & 75 & 80 & 85 & 90 & 94 & 87 & 65 & 71 & 78 & 80 & 76 & 76 & 78 & 83 & 85 & 88 & 85 & 90 & 89 & 93 & 92 & 97 & 87 & 78 & 74 & 83 & 70 & 76 & 79\end{array}$ 1982 Aug. $\begin{array}{llllllllllllllllllllllllllllllllll} & 71 & 75 & 75 & 80 & 85 & 90 & 94 & 87 & 65 & 71 & 78 & 80 & 76 & 76 & 78 & 83 & 85 & 88 & 85 & 90 & 89 & 93 & 92 & 97 & 87 & 78 & 74 & 83 & 70 & 76 & 79 \\ \end{array}$ 1982 Aug. Low $5 \begin{array}{llllllllllllllllllllllllllllllll}58 & 53 & 47 & 45 & 45 & 49 & 53 & 63 & 59 & 60 & 53 & 53 & 50 & 47 & 45 & 46 & 48 & 53 & 51 & 57 & 51 & 50 & 51 & 52 & 52 & 47 & 48 & 44 & 59 & 51 & 48\end{array}$ $\begin{array}{lllllllllllllllllllllllllllllllllllll}1982 & \text { Sep. } & \text { High } & 87 & 93 & 69 & 79 & 84 & 86 & 83 & 83 & 67 & 69 & 62 & 75 & 76 & 74 & 77 & 83 & 81 & 79 & 70 & 60 & 74 & 79 & 82 & 72 & 67 & 64 & 66 & 64 & 62 & 72 & -\end{array}$ 1982 Sep. L Low $49 \begin{array}{lllllllllllllllllllllllllllllll}56 & 58 & 58 & 54 & 50 & 50 & 48 & 49 & 46 & 45 & 48 & 41 & 42 & 42 & 37 & 43 & 51 & 56 & 55 & 55 & 45 & 47 & 57 & 55 & 47 & 42 & 41 & 36 & 40 & -\end{array}$

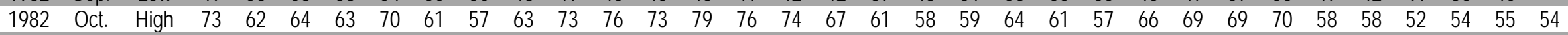
1982 Oct. L Low $40 \begin{array}{llllllllllllllllllllllllllllllll}47 & 34 & 45 & 37 & 47 & 45 & 53 & 51 & 41 & 39 & 39 & 39 & 39 & 45 & 45 & 40 & 35 & 27 & 32 & 47 & 53 & 47 & 43 & 50 & 47 & 44 & 39 & 42 & 35 & 43\end{array}$ $\begin{array}{llllllllllllllllllllllllllllllllllllllllllll}1982 & \text { Nov. } & \text { High } & 59 & 59 & 58 & 58 & 51 & 52 & 52 & 50 & 52 & 53 & 45 & 48 & 45 & 52 & 52 & 54 & 59 & 52 & 52 & 48 & 46 & 50 & 48 & 44 & 41 & 40 & 54 & 56 & 53 & 50 & - \\ 1982 & \text { Nov. } & \text { L } & 34 & 28 & 38 & 37 & 38 & 35 & 30 & 29 & 26 & 24 & 23 & 30 & 31 & 23 & 33 & 45 & 48 & 43 & 42 & 38 & 31 & 23 & 30 & 23 & 23 & 30 & 37 & 48 & 44 & 43 & -\end{array}$

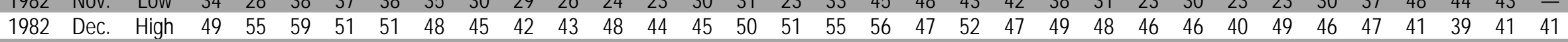
1982 Dec. Low $40 \begin{array}{llllllllllllllllllllllllllllllllllllllll}40 & 49 & 41 & 43 & 32 & 32 & 31 & 26 & 25 & 23 & 34 & 41 & 44 & 47 & 45 & 40 & 40 & 40 & 41 & 41 & 40 & 32 & 30 & 33 & 34 & 28 & 22 & 24 & 19 & 18\end{array}$

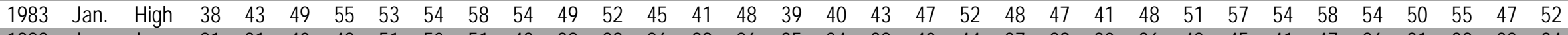

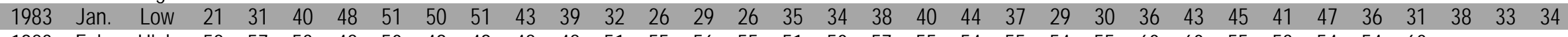

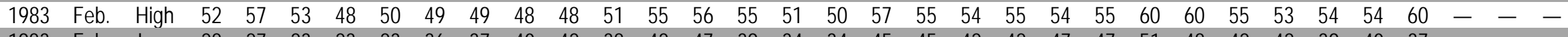

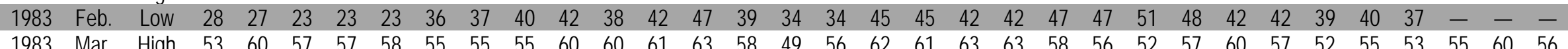

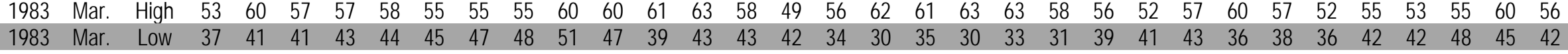

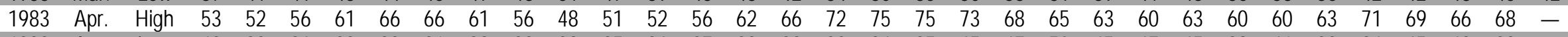
1983 Apr. Low $44 \begin{array}{lllllllllllllllllllllllllllllllllllllll}39 & 36 & 29 & 33 & 31 & 38 & 29 & 38 & 35 & 36 & 27 & 29 & 29 & 32 & 34 & 35 & 45 & 47 & 50 & 45 & 47 & 45 & 38 & 41 & 39 & 34 & 45 & 43 & 38 & -\end{array}$ 1983 May. High 60 \begin{tabular}{lllllllllllllllllllllllllllllllllllllll}
60 & 64 & 66 & 63 & 63 & 59 & 52 & 55 & 64 & 65 & 75 & 76 & 60 & 62 & 63 & 69 & 69 & 75 & 80 & 74 & 83 & 87 & 87 & 78 & 79 & 87 & 100 & 80 & 64 & 61 \\
\hline
\end{tabular} 1983 May. Low $45 \begin{array}{llllllllllllllllllllllllllllllll}45 & 40 & 34 & 42 & 40 & 43 & 42 & 40 & 42 & 37 & 39 & 41 & 47 & 46 & 37 & 42 & 49 & 38 & 43 & 49 & 42 & 48 & 45 & 46 & 43 & 45 & 53 & 58 & 56 & 55\end{array}$ $\begin{array}{lllllllllllllllllllllllllllllllllllllllll}1983 & \text { Jun. } & \text { High } & 63 & 68 & 68 & 70 & 73 & 81 & 87 & 78 & 69 & 66 & 68 & 72 & 80 & 70 & 72 & 73 & 70 & 66 & 66 & 70 & 76 & 64 & 66 & 72 & 76 & 75 & 79 & 75 & 74 & 63 & - \\ 1983 & \text { Jun. } & \text { Low } & 54 & 50 & 48 & 43 & 45 & 44 & 46 & 49 & 50 & 49 & 47 & 48 & 47 & 51 & 53 & 44 & 53 & 53 & 52 & 43 & 40 & 55 & 49 & 47 & 47 & 54 & 55 & 48 & 50 & 52 & -\end{array}$ 
Appendix C1. Average Temperature Data for Willamette Valley by Month 1980-Present

\begin{tabular}{|c|c|c|c|c|c|c|c|c|c|c|c|c|c|c|c|c|c|c|c|c|c|c|c|c|c|c|c|c|c|c|c|c|c|}
\hline 0,2 & Jul. & High & 70 & 70 & 75 & 82 & 70 & 72 & 67 & 69 & 73 & 78 & 87 & 76 & 70 & 73 & 72 & 76 & 7 & 79 & 76 & 78 & 84 & 85 & 81 & 75 & 75 & 78 & 73 & 76 & 84 & 93 & \\
\hline 983 & Jul. & Low & 55 & 48 & 45 & 45 & 50 & 50 & 54 & 48 & 40 & 46 & 50 & 60 & 50 & 47 & 50 & 52 & 52 & 56 & 60 & 57 & 47 & 52 & 56 & 59 & 59 & 56 & 60 & 53 & 45 & & \\
\hline 983 & Aug. & High & 79 & 81 & 80 & 83 & 79 & 88 & 86 & 81 & 83 & 77 & 80 & 86 & 93 & 90 & 84 & 85 & 86 & 85 & 81 & 81 & 85 & 81 & 73 & 77 & 82 & 81 & 83 & 72 & 71 & 73 & 76 \\
\hline 983 & Aug. & Low & 61 & 61 & 51 & 45 & 53 & 48 & 54 & 56 & 61 & 60 & 53 & 54 & 53 & 61 & 53 & 48 & 50 & 50 & 50 & 51 & 47 & 49 & 60 & 54 & 46 & 57 & 55 & 56 & 62 & 61 & 58 \\
\hline 1983 & Sep. & High & 75 & 77 & 79 & 74 & 75 & 78 & 73 & 69 & 73 & 72 & 76 & 82 & 82 & 75 & 80 & 74 & 70 & 68 & 71 & 79 & 85 & 81 & 75 & 76 & 78 & 70 & 68 & 70 & 74 & 76 & \\
\hline 83 & Sep. & Low & 56 & 54 & 48 & 51 & 45 & 43 & 45 & 45 & 45 & 35 & 54 & 46 & 48 & 50 & $\pi$ & 46 & 40 & 43 & 40 & 36 & 46 & 48 & 50 & 50 & 43 & 49 & 42 & 34 & 33 & 33 & \\
\hline 983 & Oct. & High & 74 & 66 & 74 & 70 & 69 & 67 & 73 & 68 & 66 & 71 & 73 & 71 & 61 & 67 & 65 & 63 & 65 & 59 & 60 & 63 & 63 & 63 & 63 & 63 & 66 & 66 & 57 & 51 & 54 & 64 & \\
\hline 1983 & Oct. & Low & 34 & 41 & 50 & 42 & 35 & 39 & 34 & 41 & 48 & 43 & 40 & 40 & 44 & 49 & 35 & 31 & 39 & 37 & 41 & 43 & 42 & 47 & 37 & 32 & 33 & 34 & 38 & 43 & 46 & 51 & 14 \\
\hline 1983 & Nov. & High & 60 & 63 & 64 & 60 & 58 & 56 & 55 & 47 & 60 & 60 & 60 & 57 & 55 & 55 & 64 & 58 & 55 & 55 & 56 & 49 & 50 & 47 & 57 & 59 & 51 & 52 & 55 & 55 & 51 & 44 & \\
\hline 1983 & Nov. & Low & 52 & 54 & 51 & 37 & 35 & 44 & 35 & 33 & 44 & 47 & 46 & 44 & 45 & 45 & 51 & 50 & 47 & 44 & 45 & 42 & 35 & 39 & 44 & 43 & 42 & 43 & 48 & 35 & 34 & 36 & \\
\hline 983 & Dec. & High & 45 & 50 & 45 & 45 & 49 & 45 & 50 & 54 & 55 & 54 & 49 & 50 & 55 & 52 & 49 & 42 & 43 & 39 & 44 & 34 & 25 & 24 & 27 & 26 & 40 & 41 & 44 & 35 & 36 & 52 & \\
\hline 1983 & Dec. & Low & 35 & 40 & 37 & 35 & 41 & 41 & 40 & 43 & 39 & 45 & 37 & 42 & 49 & 42 & 39 & 35 & 32 & 35 & 29 & 22 & 19 & 12 & 11 & 16 & 25 & 29 & 30 & 20 & 32 & 35 & 39 \\
\hline 1984 & Jan. & High & 42 & 54 & 63 & 65 & 60 & 54 & 57 & 53 & 51 & 51 & 53 & 45 & 49 & 44 & 45 & 41 & 43 & 38 & 41 & 35 & 50 & 56 & 52 & 61 & 55 & 51 & 59 & 57 & 61 & 61 & 53 \\
\hline 984 & Jan. & Low & 35 & 37 & 53 & 51 & 47 & 48 & 36 & 38 & 36 & 42 & 41 & 33 & 24 & 25 & 21 & 16 & 15 & 19 & 30 & 20 & 33 & 47 & 45 & 52 & 39 & 35 & 35 & 35 & 36 & 29 & 20 \\
\hline 984 & Feb. & High & 52 & 50 & 52 & 64 & 58 & 62 & 56 & 61 & 49 & 50 & 55 & 55 & 51 & 50 & 52 & 53 & 54 & 57 & 54 & 55 & 48 & 46 & 47 & 46 & 54 & 50 & 58 & 59 & 55 & - & \\
\hline 1984 & Feb. & Low & 26 & 24 & 26 & 27 & 26 & 34 & 29 & 44 & 42 & 39 & 42 & 47 & 36 & 36 & 40 & 31 & 25 & 37 & 35 & 43 & 34 & 33 & 41 & 41 & 35 & 31 & 31 & 35 & 39 & - & \\
\hline 1984 & Mar. & High & 56 & 55 & 53 & 65 & 64 & 66 & 63 & 67 & 67 & 64 & 52 & 56 & 59 & 55 & 60 & 56 & 55 & 53 & 62 & 62 & 56 & 62 & 57 & 56 & 50 & 57 & 59 & 54 & 57 & 60 & 64 \\
\hline 984 & Mar. & Low & 41 & 39 & 30 & 27 & 28 & 30 & 35 & 39 & 43 & 36 & 33 & 41 & 44 & 46 & 45 & 42 & 41 & 45 & 47 & 43 & 44 & 44 & 37 & 39 & 39 & 36 & 34 & 42 & 33 & 26 & 44 \\
\hline 984 & Apr. & High & 57 & 58 & 57 & 52 & 56 & 59 & 54 & 52 & 50 & 54 & 55 & 56 & 57 & 77 & 55 & 58 & 60 & 61 & 58 & 61 & 59 & 65 & 59 & 55 & 55 & 62 & 66 & 56 & 56 & 56 & \\
\hline 1984 & Apr. & Low & 37 & 38 & 42 & 42 & 37 & 32 & 42 & 41 & 40 & 41 & 41 & 35 & 32 & 36 & 46 & 35 & 30 & 45 & 39 & 41 & 43 & 35 & 35 & 35 & 33 & 29 & 28 & 34 & 41 & 44 & \\
\hline 1984 & May. & High & 57 & 58 & 60 & 58 & 55 & 61 & 76 & 65 & 60 & 60 & 66 & 67 & 66 & 59 & 61 & 65 & 69 & 71 & 62 & 61 & 64 & 56 & 63 & 60 & 60 & 66 & 76 & 85 & 85 & 62 & 65 \\
\hline 984 & May. & Low & 46 & 46 & 3 & 33 & 34 & 30 & 30 & 42 & 43 & 42 & 51 & 50 & 47 & 42 & 41 & 42 & 46 & 41 & 42 & 40 & 37 & 41 & 39 & 37 & 44 & 44 & 42 & 43 & 46 & 45 & 37 \\
\hline 1984 & Jun. & High & 69 & 67 & 64 & 62 & 59 & 62 & 63 & 61 & 62 & 66 & 70 & 73 & 72 & 78 & 72 & 67 & 73 & 75 & 76 & 59 & 63 & 76 & 84 & 84 & 85 & 69 & 8 & 77 & 67 & 72 & 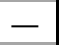 \\
\hline 1984 & Jun. & Low & 41 & 45 & 39 & 50 & 48 & 47 & 43 & 38 & 42 & 39 & 48 & 44 & 45 & 44 & 44 & 36 & 36 & 38 & 42 & 52 & 40 & 36 & 45 & 44 & 49 & 50 & 60 & 57 & 51 & 41 & \\
\hline 1984 & Jul. & High & 80 & 78 & 83 & 86 & 77 & 72 & 77 & 79 & 80 & 81 & 69 & 73 & 79 & 86 & 93 & 97 & 92 & 84 & 81 & 78 & 78 & 92 & 80 & 94 & 72 & 82 & 80 & 80 & 83 & 2 & 85 \\
\hline 984 & Jul. & Low & 44 & 53 & 48 & 50 & 50 & 44 & 39 & 45 & 49 & 49 & 44 & 52 & 44 & 46 & 51 & 59 & 54 & 45 & 45 & 49 & 46 & 46 & 52 & 58 & 53 & 46 & 47 & 53 & 48 & 50 & 55 \\
\hline 984 & Aug. & High & 78 & 81 & 80 & 82 & 76 & 81 & 90 & 95 & 94 & 87 & 81 & 75 & 79 & 82 & 87 & 84 & 83 & 80 & 82 & 86 & 86 & 80 & 76 & 80 & 88 & 94 & 79 & 76 & 85 & 74 & 69 \\
\hline 1984 & Aug. & Low & 60 & 60 & 53 & 48 & 52 & 46 & 49 & 56 & 56 & 52 & 52 & 54 & 47 & 46 & 49 & 54 & 55 & 4 & 46 & 44 & 49 & 50 & 52 & 50 & 48 & 52 & 51 & 51 & 46 & 49 & 58 \\
\hline 1984 & Sep. & High & 73 & 81 & 83 & 83 & 71 & 65 & 76 & 80 & 72 & 73 & 71 & 74 & 81 & 87 & 81 & 83 & 87 & 86 & 67 & 71 & 70 & 63 & 64 & 67 & 70 & 73 & 76 & 81 & 80 & 68 & - \\
\hline 1984 & Sep. & Low & 47 & 39 & 43 & 46 & 51 & 51 & 60 & 63 & 54 & 44 & 49 & 47 & 46 & 45 & 50 & 49 & 48 & 50 & 61 & 56 & 47 & 44 & 41 & 35 & 42 & 42 & 42 & 39 & 40 & 49 & \\
\hline 1984 & Oct. & High & 70 & 73 & 73 & 68 & 63 & 75 & 85 & 76 & 72 & 59 & 61 & 62 & 63 & 55 & 52 & 55 & 56 & 50 & 50 & 48 & 51 & 53 & 51 & 55 & 61 & 53 & 52 & 56 & 53 & 53 & 50 \\
\hline 1984 & Oct. & Low & 43 & 44 & 47 & 46 & 44 & 54 & 54 & 52 & 52 & 50 & 45 & 47 & 48 & 42 & 35 & 34 & 36 & 43 & 47 & 34 & 33 & 33 & 31 & 46 & 51 & 44 & 45 & 40 & 38 & 40 & 34 \\
\hline 1984 & Nov. & High & 53 & 58 & 59 & 59 & 52 & 55 & 59 & 47 & 50 & 57 & 54 & 60 & 51 & 53 & 49 & 53 & 51 & 55 & 53 & 51 & 43 & 46 & 51 & 42 & 45 & 41 & 48 & 50 & 47 & 49 & - \\
\hline 1984 & OV. & Low & 37 & 50 & 46 & 32 & 31 & $\Delta$ & 34 & 32 & 42 & 49 & 49 & 49 & 34 & 35 & $\tilde{n}$ & $n$ & 30 & 43 & 43 & 34 & 33 & 31 & 33 & 34 & 35 & 28 & 39 & 37 & 41 & 36 & \\
\hline 1984 & ec. & High & 40 & 45 & 47 & 45 & 44 & 42 & 42 & 43 & 45 & 45 & 41 & 48 & 47 & 48 & 40 & 43 & 41 & 33 & 30 & 39 & 46 & 50 & 52 & 40 & 37 & 49 & 45 & 44 & 45 & 48 & 40 \\
\hline 1984 & Dec. & Low & 31 & 31 & 32 & 28 & 26 & 22 & 25 & 32 & 40 & 27 & 28 & 39 & 37 & 34 & 31 & 32 & 30 & 20 & 17 & 13 & 39 & 43 & 38 & 33 & 35 & 37 & 35 & 34 & 40 & 40 & 27 \\
\hline 1985 & Jan. & High & 39 & 42 & 42 & 36 & 38 & 39 & 41 & 42 & 43 & 41 & 41 & 43 & 43 & 50 & 41 & 50 & 47 & 45 & 42 & 47 & 54 & 52 & 47 & 47 & 47 & 46 & 37 & 40 & 43 & 36 & 40 \\
\hline 1985 & Jan. & ow & 23 & 24 & 22 & $2 C$ & 23 & 30 & 2 & 25 & 23 & $\Omega$ & 21 & 23 & 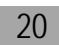 & 28 & 37 & 30 & 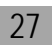 & 27 & 32 & זרי & 34 & 26 & 24 & 24 & 22 & 0 & 22 & 23 & 3 & 20 & \\
\hline 985 & Feb. & High & 46 & 34 & 36 & 33 & 42 & $4 \varepsilon$ & 44 & 43 & 42 & 46 & 5 & 47 & 51 & 58 & 52 & 49 & 52 & 51 & 47 & 49 & 51 & 58 & 62 & 56 & 51 & 52 & 58 & 58 & - & & \\
\hline 1985 & Feb. & Low & 30 & 30 & 21 & 11 & 30 & 37 & 33 & 35 & 34 & 37 & 37 & 30 & 24 & 27 & 31 & 25 & 25 & 23 & 37 & 37 & 39 & 38 & 36 & 30 & 27 & 29 & 27 & 28 & - & - & \\
\hline 985 & Mar. & High & 53 & 51 & 46 & 46 & 50 & 52 & 55 & 57 & 60 & 61 & 58 & 53 & 56 & 56 & 61 & 61 & 57 & 58 & 57 & 56 & 49 & 48 & 51 & 46 & 51 & 46 & 47 & 53 & 48 & 53 & 60 \\
\hline 385 & Mar. & Low & 30 & 23 & 34 & 36 & 32 & 28 & 23 & 26 & 29 & 30 & 25 & 30 & 26 & 27 & 27 & 31 & 31 & 28 & 32 & 36 & 36 & 38 & 38 & 32 & 33 & 33 & 36 & 37 & 32 & 45 & 50 \\
\hline
\end{tabular}


Appendix C1. Average Temperature Data for Willamette Valley by Month 1980-Present

\begin{tabular}{|c|c|c|c|c|c|c|c|c|c|c|c|c|c|c|c|c|c|c|c|c|c|c|c|c|c|c|c|c|c|c|c|c|c|}
\hline 985 & Apr. & High & & 69 & 61 & 60 & 67 & 76 & 62 & 70 & 76 & 65 & 65 & 72 & 74 & 73 & 64 & 58 & 60 & 51 & 51 & U & 51 & 52 & 58 & 53 & 55 & 57 & 66 & 57 & 65 & 69 & \\
\hline 1985 & Apr. & Low & 48 & 37 & 45 & 36 & 36 & 38 & 44 & 45 & 39 & 46 & 47 & 37 & 39 & 39 & 44 & 45 & 44 & 39 & 34 & 36 & 41 & 42 & 40 & 41 & 30 & 43 & 50 & 35 & 32 & 33 & \\
\hline 1985 & May & High & 75 & 73 & 58 & 58 & 61 & 61 & 62 & 60 & 65 & 59 & 58 & 64 & 63 & 61 & 81 & 83 & 75 & 72 & 68 & 70 & 80 & 85 & 72 & 70 & 69 & 69 & 67 & 63 & 62 & 68 & 63 \\
\hline & May & LOWV & 15 & t & 36 & & $?$ & 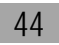 & 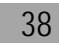 & 33 & Ju & o & 28 & 30 & 35 & 40 & 39 & 45 & 44 & 46 & 44 & 49 & 40 & 47 & 53 & 55 & 54 & 54 & 46 & 49 & 47 & 50 & \\
\hline 85 & Jun. & High & 2 & 71 & 67 & 72 & 68 & 65 & 65 & 70 & 74 & 80 & 35 & 81 & 81 & 78 & 75 & 82 & 95 & 96 & 88 & 81 & 82 & 75 & 68 & 66 & 79 & 83 & 69 & 78 & 69 & 75 & \\
\hline 985 & Jun. & Low & 48 & 47 & 43 & 54 & 49 & 55 & 48 & 41 & 43 & 41 & 46 & 53 & 49 & 54 & 50 & 40 & 46 & 51 & 53 & 43 & 45 & 50 & 43 & 37 & 39 & 48 & 43 & 42 & 45 & 46 & \\
\hline 1985 & Jul. & High & 87 & 89 & 88 & 83 & 80 & 88 & 90 & 92 & 96 & 86 & 89 & 86 & 86 & 92 & 88 & 83 & 85 & 99 & 101 & 96 & 90 & 89 & 84 & 80 & 91 & 95 & 94 & 93 & 84 & 62 & 76 \\
\hline 85 & Jul. & LoW & 44 & 52 & 46 & כ1 & 48 & 53 & 54 & 52 & 50 & 51 & 53 & 52 & 50 & 48 & 49 & 50 & 56 & 55 & 58 & 54 & 54 & 59 & 58 & 56 & 50 & 51 & 49 & 50 & 52 & 59 & \\
\hline 85 & Aug. & Hign & 77 & 80 & 87 & 82 & 82 & 8 & 70 & 75 & 77 & 74 & 84 & 82 & 94 & 94 & 86 & 92 & 91 & 68 & 70 & 73 & 75 & 86 & 92 & 8 & 91 & 92 & 74 & 76 & 77 & 72 & \\
\hline 1985 & Aug. & Low & 5/ & 52 & 51 & 56 & 47 & 47 & 56 & 55 & 46 & 50 & 45 & 49 & 50 & 51 & 51 & 50 & 51 & 53 & 51 & 48 & 42 & 45 & 49 & 61 & 53 & 48 & 46 & 41 & 42 & 48 & 13 \\
\hline 1985 & Sep. & High & 70 & 72 & 79 & 77 & 70 & 72 & 70 & 68 & 66 & 67 & 68 & 61 & 68 & 63 & 70 & 64 & 66 & 66 & 67 & 73 & 74 & 72 & 80 & 78 & 88 & 84 & 80 & 76 & 75 & 76 & \\
\hline 85 & Sep. & Low & 52 & 50 & 42 & 50 & 58 & 48 & 43 & 41 & 44 & 47 & 44 & 54 & 53 & 53 & 46 & 42 & 46 & 39 & 45 & 39 & 48 & 42 & 42 & 43 & 44 & 42 & 40 & 35 & 34 & 34 & - \\
\hline 385 & Oct. & rilgn & 15 & 75 & 73 & 81 & 78 & 64 & 62 & s/ & 62 & 62 & 63 & 60 & 62 & 70 & 62 & 65 & 63 & 67 & 57 & 63 & 54 & 57 & 58 & 60 & 59 & 63 & $6 /$ & 53 & - & 54 & 50 \\
\hline 1985 & Oct. & Low & 39 & 50 & 45 & 38 & 40 & 45 & 39 & 30 & 25 & 36 & 45 & 36 & 32 & 38 & 41 & 39 & 33 & 34 & 45 & 45 & 44 & 47 & 52 & 55 & 37 & 43 & 45 & 34 & 28 & 33 & \\
\hline 1985 & Nov. & High & 59 & 66 & 66 & 55 & 52 & 54 & 53 & 48 & 44 & 45 & 42 & 45 & 49 & 45 & 51 & 51 & 44 & 46 & 42 & 40 & 40 & 33 & 27 & 28 & 39 & 39 & 46 & 32 & 28 & 26 & \\
\hline 85 & Nov. & Low & 50 & 54 & 52 & 39 & 41 & 47 & 40 & 35 & 34 & 29 & 23 & 23 & 19 & 19 & 37 & 40 & 30 & 27 & 30 & 28 & 31 & 20 & 16 & 11 & 12 & 31 & 30 & 20 & 17 & 17 & \\
\hline 1985 & Jec. & ilgh & 24 & 46 & 4 & 45 & 52 & 51 & 51 & 48 & 3 & 46 & 40 & 41 & 39 & 41 & 43 & 43 & 43 & 41 & 42 & 39 & 40 & 41 & 43 & 45 & 42 & 40 & 37 & 36 & 40 & 38 & 43 \\
\hline 1985 & Dec & Low & $\angle 1$ & $\mathbb{Z}$ & 31 & 34 & 37 & 44 & 42 & 33 & 30 & 26 & 19 & 18 & 20 & 21 & $\angle 0$ & 23 & $\mathbb{Z}$ & 21 & 19 & 17 & 19 & 20 & 26 & $\angle b$ & 19 & 16 & 18 & 15 & 19 & 10 & 30 \\
\hline 1986 & Jan. & High & 51 & 46 & 53 & 47 & 53 & 54 & 46 & 57 & 55 & 52 & 49 & 44 & 48 & 46 & 19 & 56 & 54 & 63 & 49 & 50 & 46 & 51 & (n) & 44 & 54 & 50 & 53 & 47 & 44 & 57 & 52 \\
\hline 86 & Jan. & Low & 30 & 27 & 3 & 22 & 38 & 30 & $2 c$ & 36 & 4 & 38 & 32 & 3 & 29 & 37 & 38 & 46 & 40 & 49 & 38 & 37 & 32 & 41 & 36 & 30 & 28 & 26 & 42 & 39 & 41 & 43 & $3 y$ \\
\hline 1986 & Feb. & HIII & 58 & 57 & 5 & 48 & 48 & 4 & 50 & 51 & 49 & 41 & 40 & 37 & 5 & 39 & 55 & 50 & 40 & 40 & 46 & 50 & 52 & b8 & 59 & 65 & 58 & 63 & 70 & 59 & - & - & \\
\hline 1986 & Feb. & Low & 42 & 39 & 43 & 39 & 34 & 33 & 30 & 27 & 22 & 22 & 33 & 32 & 34 & 35 & 35 & 40 & 32 & 30 & 30 & 38 & 39 & 50 & 54 & 53 & 46 & 40 & 44 & 41 & - & - & \\
\hline 1986 & lar. & High & 64 & 65 & 62 & 66 & 67 & 60 & 59 & 53 & 56 & 64 & 57 & 54 & 54 & 56 & 58 & 60 & 54 & 57 & 64 & 70 & 59 & 60 & 57 & 55 & 58 & 69 & 68 & 67 & 68 & 58 & 62 \\
\hline 36 & Mar. & L & 40 & 33 & 36 & 39 & 37 & 46 & 45 & 42 & 4 & 40 & 44 & 42 & 35 & 36 & 3 & 39 & 43 & 42 & 39 & 37 & 35 & 31 & 75 & 40 & 39 & 48 & 39 & 42 & 42 & 38 & 31 \\
\hline 1986 & Apr. & High & 55 & 57 & 58 & 57 & 63 & 71 & 68 & 61 & 55 & 59 & 52 & 53 & 55 & 60 & 61 & 54 & 57 & 59 & 69 & 77 & 78 & 57 & 55 & 5 & 54 & 53 & 60 & 54 & 56 & 63 & \\
\hline 1986 & Apr. & Low & 41 & 34 & 32 & 42 & 33 & 35 & 36 & 51 & $4 c$ & 30 & 32 & 38 & 38 & 36 & 43 & 42 & 35 & 32 & 38 & 40 & 44 & 35 & 31 & 28 & 40 & 42 & 40 & 31 & 36 & 33 & \\
\hline 86 & May & High & 55 & 57 & 63 & 5 & 53 & 58 & 6 & 63 & 55 & 52 & 56 & 63 & 59 & 61 & 65 & 69 & 76 & 70 & 15 & 58 & 58 & 62 & 67 & 81 & 85 & 72 & 74 & 19 & 84 & 91 & 91 \\
\hline 36 & May & & & 43 & 35 & 3 & 42 & 42 & 4 & 44 & 38 & 3 & 41 & 3 & 4 & 33 & 40 & 35 & 4 & 45 & 44 & 38 & 37 & 36 & 44 & 5 & 57 & 58 & 52 & 50 & 48 & 55 & 61 \\
\hline 1986 & Jun. & High & 86 & 88 & 74 & 72 & 71 & 66 & 69 & 68 & 81 & 89 & 88 & 89 & 93 & 68 & 74 & 6 & 65 & 68 & 72 & 74 & 78 & 89 & 92 & 83 & 85 & 88 & 84 & 63 & 72 & 84 & \\
\hline 1986 & Jun. & Low & 56 & 57 & 54 & 5 & 55 & 54 & 51 & 47 & 42 & 48 & 52 & 49 & 49 & 44 & 44 & 55 & 53 & 47 & 40 & 51 & 47 & 50 & 53 & 52 & 51 & 56 & 55 & 54 & 48 & 43 & \\
\hline 86 & Jul. & High & 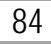 & 75 & 71 & 6 & 71 & 83 & 7 & 79 & 73 & 6 & 76 & 73 & $\pi$ & 71 & 67 & 67 & 73 & 78 & 86 & 90 & 87 & 18 & 75 & 79 & 80 & 73 & 71 & 80 & 71 & 82 & 89 \\
\hline 86 & Jul. & Low & 5 & 58 & 4 & 46 & 42 & 45 & 50 & 54 & $5 \varepsilon$ & 58 & 58 & 5 & 5 & 52 & 50 & 5 & 4 & 43 & 46 & 5 & 48 & 48 & 5 & 4 & 48 & 5 & 5 & 44 & 54 & 49 & 49 \\
\hline 86 & Aug. & & 9 & 98 & 91 & 87 & 84 & 93 & 9 & 97 & 94 & 83 & 81 & 82 & 88 & 93 & $\varepsilon$ & 81 & 88 & 77 & 82 & 92 & 89 & 88 & 85 & 86 & 92 & 98 & 8 & 73 & 70 & 73 & 77 \\
\hline 1986 & Aug. & Low & 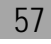 & 62 & 5 & 47 & 48 & 52 & 58 & $\sim$ & 56 & 54 & 51 & 53 & 53 & 53 & 54 & 46 & 46 & 50 & 46 & 50 & 53 & 48 & 50 & 46 & 51 & 55 & 60 & 57 & 60 & 59 & 55 \\
\hline 1986 & Sep. & High & 84 & 81 & 88 & 93 & 91 & 90 & 78 & 68 & 72 & 68 & 71 & 71 & 64 & 72 & 70 & 70 & 61 & 68 & 72 & 61 & 88 & 69 & 58 & 59 & 62 & 55 & 61 & 64 & 64 & 61 & - \\
\hline 15 & Sep. & 1 & 1 & 59 & 5 & 53 & 50 & 5 & $4 \varepsilon$ & 46 & 53 & 1 & 37 & 4 & 4 & 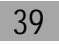 & 46 & 46 & . & 48 & 43 & 51 & 46 & 40 & 46 & 46 & 48 & 47 & 46 & 46 & 50 & 48 & \\
\hline 86 & Oct. & t & 6 & 6 & 6 & 6 & $7 \varepsilon$ & 7 & 7 & 69 & 6 & 7 & 76 & 7 & 7 & 69 & & 6 & 57 & $\epsilon$ & $c$ & & & 6 & & 65 & & & & & & 59 & \\
\hline 1986 & Oct. & Low & 4 & 37 & 45 & 4 & 45 & 45 & 43 & 45 & 4 & 4 & 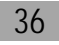 & 32 & 3 & 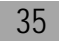 & 36 & 36 & 45 & 39 & 38 & 39 & 37 & 42 & 43 & 45 & 55 & 55 & 42 & 42 & 45 & 52 & 41 \\
\hline 1986 & Nov. & High & 63 & 63 & 62 & 54 & 60 & 56 & 56 & 56 & 49 & 46 & 57 & 53 & 47 & 47 & 51 & 51 & 56 & 56 & 55 & 59 & 52 & 51 & 50 & 57 & 48 & 53 & 52 & 49 & 51 & 41 & \\
\hline 1986 & Nov. & Low & 45 & 39 & 35 & 34 & 39 & 37 & 38 & 39 & 3 & 29 & 40 & 36 & 32 & 43 & 45 & $4 \pi$ & 3 & 46 & 48 & 4 & 45 & 40 & ${ }_{\perp}$ & $x$ & 31 & 40 & 44 & 41 & 32 & 29 & \\
\hline 1986 & Dec & 1 & 46 & 49 & 4 & 4 & 46 & 46 & 37 & 43 & 45 & 44 & 36 & 43 & 53 & 52 & 47 & 42 & 40 & 37 & 45 & 42 & 56 & 53 & $\infty$ & Ss & 48 & 57 & 53 & 41 & 55 & 42 & 52 \\
\hline 86 & Dec & Low & 36 & 31 & 27 & 36 & 3 & & 2 & & & 2 & & & & & & & & & & 26 & 37 & & & & & 2 & st & & 37 & 31 & \\
\hline
\end{tabular}


Appendix C1. Average Temperature Data for Willamette Valley by Month 1980-Present

\begin{tabular}{|c|c|c|c|c|c|c|c|c|c|c|c|c|c|c|c|c|c|c|c|c|c|c|c|c|c|c|c|c|c|c|c|c|c|}
\hline & & & & 2 & 3 & 4 & 5 & 6 & & 8 & $y$ & 10 & 11 & 12 & 13 & 14 & 15 & 16 & 17 & 18 & 19 & 20 & 21 & 22 & 23 & 24 & 25 & 26 & 27 & 28 & 29 & 50 & \\
\hline 987 & Jan. & High & 49 & 51 & 54 & 49 & 49 & 47 & 45 & 40 & 43 & 48 & 56 & 50 & 43 & 45 & 39 & 38 & 39 & 45 & 41 & 42 & 40 & 39 & 50 & 49 & 53 & 56 & 49 & 50 & 56 & 53 & 54 \\
\hline 987 & Jan. & Low & 38 & 41 & 43 & 38 & 32 & 26 & 21 & 19 & 20 & 26 & 28 & 39 & 36 & 24 & 21 & 19 & 19 & 25 & 25 & 21 & 23 & 27 & 33 & 44 & 43 & 43 & 44 & 42 & 43 & 40 & 13 \\
\hline 987 & Feb. & High & 53 & 51 & 54 & 56 & 58 & 55 & 52 & 57 & 53 & 57 & 60 & 52 & 53 & 53 & 51 & 49 & 50 & 52 & 53 & 51 & 52 & 52 & 50 & 50 & 51 & 50 & 50 & 51 & - & - & \\
\hline 1987 & Feb. & Low & 42 & 40 & 40 & 34 & 35 & 31 & 29 & 39 & 33 & 42 & 35 & 33 & 45 & 38 & 43 & 42 & 36 & 32 & 32 & 35 & 31 & 32 & 33 & 25 & 23 & 25 & 36 & 37 & - & - & \\
\hline 987 & Mar. & High & 54 & 59 & 60 & 62 & 57 & 54 & 57 & 56 & 54 & 61 & 54 & 54 & 54 & 53 & 55 & 56 & 56 & 50 & 53 & 56 & 61 & 60 & 55 & 55 & 54 & 55 & 55 & 61 & 65 & 71 & 72 \\
\hline 987 & Mar. & Low & 45 & 45 & 51 & 45 & 41 & 35 & 33 & 38 & 46 & 44 & 45 & 50 & 46 & 35 & 31 & 36 & 41 & 35 & 33 & 40 & 30 & 32 & 35 & 29 & 30 & 29 & 28 & 27 & 32 & 29 & \\
\hline 987 & Apr. & High & 78 & 72 & 56 & 63 & 55 & 59 & 61 & 58 & 64 & 55 & 57 & 60 & 69 & 73 & 68 & 61 & 50 & 53 & 56 & 64 & 70 & 69 & 69 & 64 & 68 & 85 & 84 & 71 & 77 & 60 & 72 \\
\hline 1987 & Apr. & Low & 37 & 42 & 40 & 35 & 41 & 35 & 36 & 42 & 33 & 43 & 35 & 34 & 36 & 39 & 46 & 41 & 38 & 35 & 30 & 32 & 38 & 44 & 43 & 33 & 38 & 37 & 44 & 50 & 41 & 47 & 35 \\
\hline 987 & May. & High & 57 & 58 & 74 & 69 & 79 & 90 & 94 & 94 & 86 & 84 & 83 & 68 & 74 & 71 & 64 & 67 & 63 & 63 & 64 & 70 & 74 & 68 & 71 & 66 & 61 & 67 & 64 & 63 & 71 & 61 & b3 \\
\hline 987 & May. & Low & 45 & 45 & 48 & 46 & 41 & 49 & 54 & 56 & 49 & 46 & 44 & 54 & 54 & 58 & 47 & 37 & 39 & 33 & 36 & 34 & 39 & 36 & 37 & 49 & 46 & 49 & 50 & 47 & 38 & 50 & \\
\hline 987 & Jun. & High & 66 & 77 & 90 & 76 & 65 & 76 & 82 & 75 & 74 & 76 & 83 & 84 & 87 & 80 & 64 & 63 & 73 & 80 & 84 & 65 & 69 & 72 & 79 & 87 & 98 & 97 & 90 & 87 & 95 & 2 & \\
\hline 1987 & Jun. & Low & 42 & 43 & 46 & 51 & 54 & 52 & 46 & 51 & 47 & 46 & 41 & 49 & 50 & 50 & 50 & 47 & 44 & 42 & 43 & 51 & 47 & 45 & 45 & 48 & 56 & 54 & 53 & 49 & 55 & 55 & \\
\hline 987 & Jul. & High & 82 & 77 & 80 & 70 & 72 & 73 & 74 & 73 & 72 & 79 & 90 & 94 & 95 & 97 & 79 & 65 & 65 & 60 & 78 & 87 & 84 & 67 & 79 & 78 & 77 & 73 & 78 & 79 & 77 & 73 & 75 \\
\hline 387 & Jul. & Low & 55 & 54 & 49 & 54 & 55 & 44 & 48 & 55 & $4 l$ & 58 & 53 & 54 & 55 & 54 & 42 & 51 & 54 & 54 & 52 & 50 & 53 & 52 & 51 & 57 & 56 & 54 & 52 & 2 & 48 & 54 & 52 \\
\hline 987 & Aug. & High & 81 & 87 & 95 & 88 & 78 & 77 & 93 & 99 & 80 & 72 & 76 & 80 & 69 & 72 & 73 & 74 & 80 & 88 & 86 & 76 & 80 & 88 & 85 & 87 & 89 & 90 & 89 & 86 & 91 & 97 & .00 \\
\hline 1987 & Aug. & Low & 49 & 45 & 53 & 52 & 54 & 50 & 51 & 56 & 53 & 57 & 54 & 49 & 56 & 56 & 55 & 50 & 45 & 52 & 47 & 47 & 44 & 52 & 58 & 48 & 47 & 53 & 50 & 49 & 53 & 53 & 60 \\
\hline 987 & Sep. & High & 95 & 77 & 77 & 85 & 94 & 87 & 79 & 76 & 87 & 73 & 65 & 67 & 71 & 66 & 66 & 69 & 80 & 81 & 82 & 84 & 85 & 93 & 81 & 66 & 67 & 69 & 74 & 84 & 89 & 88 & - \\
\hline 987 & Sep. & Low & 54 & 51 & 42 & 45 & 49 & 50 & 50 & 48 & 46 & 50 & 57 & 57 & 50 & 49 & 42 & 39 & 39 & 42 & 42 & 44 & 44 & 46 & 49 & 52 & 54 & 47 & 39 & 40 & 44 & 44 & \\
\hline 987 & Oct. & High & 89 & 73 & 73 & 77 & 85 & 88 & 84 & 65 & 83 & 83 & 82 & 72 & 69 & 64 & 65 & 71 & 67 & 68 & 79 & 75 & $6 /$ & 63 & 66 & 64 & 67 & 70 & 12 & 74 & 62 & 67 & 60 \\
\hline 1987 & Oct. & Low & 45 & 49 & 50 & 48 & 44 & 45 & 45 & 44 & 43 & 44 & 38 & 40 & 3 & 37 & 32 & 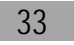 & 32 & 38 & 37 & 37 & 2 & 34 & 34 & 35 & 34 & 37 & 3 & 34 & 38 & 54 & 52 \\
\hline 987 & Nov. & High & 62 & 60 & 54 & 56 & 58 & 57 & 63 & 62 & 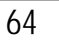 & 58 & 56 & $\checkmark$ & 57 & 51 & 47 & 54 & 55 & 54 & 58 & 59 & 53 & 53 & 52 & 52 & 51 & 45 & 42 & 48 & 40 & 57 & \\
\hline 1987 & Nov. & Low & 50 & 47 & 42 & 37 & 38 & 48 & 41 & 40 & 45 & 38 & 51 & 5 & 41 & 40 & 39 & 38 & 35 & 31 & 33 & 37 & $43^{2}$ & 38 & 38 & 39 & 35 & 34 & 35 & 29 & 28 & 33 & \\
\hline 1987 & Dec. & High & 57 & 57 & 56 & 48 & 51 & 51 & 56 & 53 & 59 & 50 & 45 & 40 & 36 & 43 & 3 & 35 & 37 & 31 & 35 & 44 & 45 & 47 & 40 & 34 & 36 & 38 & 35 & 37 & 39 & 38 & 43 \\
\hline 1987 & Dec. & Low & 46 & 47 & 45 & 44 & 45 & 45 & 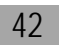 & 42 & 43 & $n$ & 29 & 2 & 3 & 31 & 3 & 30 & 30 & 32 & 32 & 33 & 35 & 34 & 28 & 25 & $\angle 4$ & 20 & 27 & 30 & 6 & 3 & 34 \\
\hline 988 & Jan. & High & 42 & 39 & 36 & 36 & 40 & $x$ & 40 & 48 & 54 & 47 & 50 & 4 & 52 & 56 & 47 & 47 & 40 & 41 & 44 & 53 & 44 & 45 & 42 & 45 & 43 & 45 & 50 & 60 & 53 & 44 & 41 \\
\hline 1988 & Jan. & Low & 27 & 19 & 31 & 32 & 27 & 30 & 31 & 33 & 39 & 40 & 37 & 3 & 40 & 41 & 3 & 36 & 30 & 33 & 32 & 36 & 29 & 35 & 37 & 30 & 29 & 29 & 36 & 38 & 37 & 34 & 32 \\
\hline 988 & Feb. & High & 3 & 41 & 52 & 40 & 43 & 52 & 52 & 56 & 52 & 60 & 52 & 53 & 50 & 50 & 5 & 52 & 48 & 52 & 53 & 46 & 58 & 53 & 62 & 59 & 61 & 66 & 66 & 67 & 59 & - & - \\
\hline 1988 & Feb. & Low & 22 & 19 & 29 & 25 & 27 & 3. & 40 & 45 & 47 & 35 & 34 & 4 & 35 & 33 & 37 & 33 & 30 & 38 & 33 & 30 & 32 & 29 & 25 & 29 & 31 & 37 & 36 & 37 & 47 & - & - \\
\hline 988 & Mar. & $\mathrm{Hi}$ & 56 & 52 & 54 & 54 & 51 & 4 & 54 & 49 & 51 & 50 & 57 & 5 & 57 & 60 & 6 & 66 & 65 & 69 & 70 & 59 & 54 & 59 & 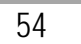 & 49 & 61 & 3 & 54 & 55 & 0 & 56 & 62 \\
\hline 1988 & Mar. & Low & 38 & 39 & 34 & 3 & 35 & 3. & 4 & 37 & 36 & 30 & 24 & 26 & 27 & 28 & 2 & 27 & 29 & $2 C$ & 33 & $4 \varepsilon$ & 39 & 43 & 42 & 42 & 48 & 37 & 36 & 34 & 39 & 36 & 33 \\
\hline 1988 & Apr. & High & 67 & 53 & 53 & 56 & 62 & 55 & 53 & 56 & 73 & 77 & 75 & 79 & 59 & 53 & 60 & 59 & 56 & 64 & 62 & 59 & 51 & 59 & 60 & 57 & 64 & 73 & 73 & 64 & 56 & 51 & - \\
\hline 1988 & Apr. & Low & 34 & 47 & 41 & 39 & 45 & 36 & 33 & 28 & $3=$ & 38 & 39 & 41 & 48 & 48 & 47 & 49 & 40 & 34 & 48 & 47 & 43 & 43 & 38 & 38 & 30 & 43 & 50 & 49 & 40 & 38 & - \\
\hline 1988 & May. & High & 54 & 56 & 52 & 57 & 56 & 51 & 66 & 57 & 65 & 79 & 83 & 7 & 61 & 68 & 7 & 62 & 61 & 65 & 67 & 75 & 85 & 68 & 64 & 68 & 69 & 66 & 7 & 62 & 62 & $2<$ & D \\
\hline 1988 & lay. & Low & 35 & 40 & 38 & 3 & 39 & 41 & 46 & 42 & 35 & 44 & 48 & 4 & 50 & 4 & 4 & 43 & 17 & 4 & 37 & 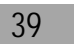 & a & 10 & 35 & 40 & 10 & 12 & 55 & 17 & 40 & 37 & 10 \\
\hline 1988 & Jun. & High & 61 & 65 & 68 & 66 & 63 & 66 & 63 & 68 & 64 & 68 & 74 & 73 & 81 & 90 & 82 & 80 & 74 & 75 & 81 & 79 & 86 & 79 & 73 & 85 & 74 & 70 & 71 & 65 & 69 & 77 & \\
\hline 1988 & Jun. & Low & 49 & 46 & 46 & 48 & 39 & 38 & 49 & 47 & 49 & 49 & 44 & 41 & 43 & 49 & 49 & 48 & 50 & 54 & 50 & 46 & 52 & 56 & 52 & 48 & 52 & 55 & 53 & 47 & 49 & 41 & 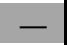 \\
\hline 1988 & Jul. & High & 77 & 72 & 70 & 68 & 67 & 72 & 86 & 88 & 86 & 82 & 69 & 7 & 67 & 75 & 7 & 82 & 83 & 92 & 103 & 101 & 89 & 84 & 81 & 94 & 102 & 103 & 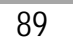 & 81 & 88 & 90 & 19 \\
\hline 88 & Jul. & Low & 46 & 57 & 50 & 46 & 43 & 38 & 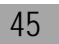 & 47 & 4 & 50 & & 5 & 57 & 51 & & 44 & 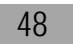 & & 50 & -0 & & & 15 & & & & & 5 & & & \\
\hline 1988 & Aug. & High & 76 & 86 & 95 & 96 & 82 & 73 & 78 & 86 & 86 & 79 & 70 & 76 & 71 & 73 & 7 & 75 & 74 & 78 & 83 & 76 & 86 & 97 & 102 & 88 & 87 & 84 & 93 & 96 & 9 & 77 & 87 \\
\hline 1988 & Aug. & Low & 43 & 46 & 52 & 52 & 52 & 45 & 45 & 47 & 53 & 56 & 50 & 53 & 53 & 56 & 48 & 58 & 51 & 44 & 46 & 44 & 41 & 45 & 50 & 49 & 44 & 46 & 53 & 54 & 52 & 44 & 44 \\
\hline 988 & Sep. & High & 102 & 104 & 94 & 88 & 86 & 8 & 77 & 84 & 76 & 71 & 82 & 88 & 90 & 87 & 66 & 69 & 70 & 74 & 67 & 68 & 73 & 99 & 75 & 77 & 67 & 68 & 70 & 75 & 4 & 86 & \\
\hline 988 & Sep. & Low & 47 & 54 & 51 & 51 & 51 & 47 & 53 & 44 & 42 & 38 & 40 & 44 & 43 & 45 & 42 & 44 & 41 & 34 & 47 & 46 & 40 & 39 & 43 & 51 & 56 & 54 & 44 & 41 & 44 & 50 & 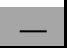 \\
\hline
\end{tabular}


Appendix C1. Average Temperature Data for Willamette Valley by Month 1980-Present

\begin{tabular}{|c|c|c|c|c|c|c|c|c|c|c|c|c|c|c|c|c|c|c|c|c|c|c|c|c|c|c|c|c|c|c|c|c|c|}
\hline 98 & Oct. & $\mathrm{H} \|$ & $y_{2}$ & 76 & 63 & 64 & 68 & 66 & 65 & 70 & 75 & 72 & 62 & 71 & 62 & 66 & 75 & 76 & 69 & 66 & 71 & 65 & 65 & 63 & 68 & 64 & 59 & 60 & 63 & 61 & 62 & 73 & \\
\hline 1988 & Oct. & Low & 49 & 46 & 45 & 44 & 55 & 46 & 55 & 49 & 47 & 46 & 52 & 47 & 52 & 57 & 59 & 57 & 48 & 45 & 51 & 44 & 44 & 39 & 37 & 42 & 39 & 34 & 27 & 31 & 38 & 45 & \\
\hline 1988 & Nov. & High & 56 & 58 & 61 & 61 & 65 & 57 & 50 & 55 & 50 & 57 & 56 & 54 & 50 & 50 & 54 & 51 & 51 & 48 & 48 & 52 & 54 & 57 & 47 & 44 & 50 & 51 & 50 & 54 & 48 & 39 & \\
\hline 1988 & Nov. & Low & 42 & 53 & 50 & 48 & 49 & 38 & 39 & 44 & 42 & 43 & 41 & 41 & 34 & 42 & 45 & 43 & 39 & 41 & 37 & 46 & 45 & 43 & 37 & 37 & 41 & 33 & 40 & 37 & 30 & 31 & \\
\hline 988 & Dec. & High & 38 & 42 & 45 & 38 & 58 & 60 & 52 & 48 & 50 & 49 & 49 & 58 & 52 & 45 & 49 & 53 & 49 & 48 & 49 & 44 & 48 & 45 & 43 & 39 & 38 & 41 & 42 & 40 & 49 & 49 & 17 \\
\hline 988 & Dec. & Low & 31 & 30 & 30 & 29 & 36 & 47 & 34 & 33 & 45 & 45 & 45 & 42 & 29 & 29 & 25 & 34 & 24 & 20 & 33 & 39 & 38 & 37 & 37 & 33 & 27 & 26 & 33 & 30 & 39 & 39 & 36 \\
\hline 1989 & Jan. & High & 49 & 50 & 59 & 50 & 47 & 42 & 42 & 48 & 52 & 46 & 46 & 50 & 44 & 42 & 48 & 50 & 51 & 55 & 51 & 50 & 44 & 45 & 35 & 43 & 44 & 40 & 49 & 49 & 60 & 57 & 48 \\
\hline 1989 & Jan. & LOW & 40 & 42 & 44 & 38 & 35 & 32 & 33 & 35 & 42 & 36 & 30 & 34 & 33 & 34 & 41 & 47 & 46 & 40 & 35 & 37 & 37 & 26 & 24 & 30 & 27 & 32 & 29 & 28 & 33 & 35 & 33 \\
\hline 889 & Feb. & High & 34 & 23 & 16 & 24 & 34 & 36 & 36 & 42 & 45 & 37 & 45 & 43 & 44 & 45 & 48 & 49 & 50 & 46 & 51 & 57 & 48 & 53 & 51 & 53 & 55 & 50 & 49 & 53 & - & - & \\
\hline 989 & Feb. & Low & 23 & 12 & 6 & 3 & -1 & 6 & 8 & 12 & 24 & 26 & 33 & 35 & 34 & 27 & 23 & 39 & 45 & 39 & 39 & 35 & 35 & 39 & 38 & 29 & 33 & 29 & 28 & 29 & - & - & \\
\hline 1989 & Mar. & High & 49 & 41 & 46 & 39 & 58 & 56 & 55 & 62 & 64 & 56 & 62 & 56 & 45 & 51 & 61 & 53 & 52 & 55 & 57 & 59 & 58 & 56 & 58 & 54 & 56 & 48 & 52 & 57 & 56 & 52 & 57 \\
\hline 989 & Mar. & Low & 32 & 31 & 29 & 29 & 37 & 42 & 36 & 34 & 45 & 42 & 47 & 45 & 39 & 40 & 43 & 41 & 41 & 37 & 33 & 29 & 42 & 40 & 34 & 44 & 37 & 40 & 45 & 42 & 41 & 35 & 42 \\
\hline 989 & Apr. & High & 55 & 52 & 58 & 59 & 70 & 72 & 69 & 69 & 78 & 71 & 71 & 78 & 78 & 76 & 64 & 64 & 72 & 73 & 75 & 60 & 61 & 57 & 62 & 62 & 59 & 58 & 64 & 73 & 80 & 64 & \\
\hline 1989 & Apr. & Low & 40 & 34 & 35 & 45 & 48 & 43 & 45 & 39 & 41 & 45 & 39 & 40 & 42 & 50 & 48 & 42 & 39 & 49 & 54 & 48 & 43 & 41 & 40 & 46 & 48 & 38 & 35 & 34 & 36 & 43 & \\
\hline 1989 & May. & High & 70 & 73 & 66 & 81 & 81 & 78 & 79 & 76 & 57 & 61 & 63 & 63 & 72 & 77 & 80 & 70 & 65 & 61 & 64 & 71 & 61 & 68 & 56 & 62 & 62 & 65 & 64 & 65 & 62 & 70 & 78 \\
\hline 989 & May. & Low & 43 & 43 & 39 & 48 & 54 & 53 & 49 & 43 & 46 & 46 & 42 & 39 & 34 & 41 & 41 & 43 & 42 & 42 & 42 & 34 & 46 & 46 & 43 & 46 & 46 & 47 & 48 & 45 & 45 & 46 & 43 \\
\hline 989 & Jun. & High & 85 & 86 & 88 & 90 & 87 & 16 & 76 & 73 & I1 & 79 & 85 & 64 & 76 & 65 & 11 & 10 & ib & 14 & 68 & 71 & 80 & 80 & 91 & 96 & 89 & 13 & 10 & 69 & 61 & 67 & \\
\hline 1989 & Jun. & Low & 48 & 50 & 48 & 50 & 50 & 49 & 42 & 46 & 52 & 42 & 47 & 48 & 56 & 55 & 52 & 43 & 44 & 51 & 50 & 49 & 47 & 48 & 56 & 55 & 55 & 52 & 49 & 53 & 53 & 51 & \\
\hline 1989 & Jul. & High & 64 & 77 & 75 & 77 & 80 & 86 & 81 & 71 & 69 & 75 & 82 & 86 & 76 & 81 & 75 & 67 & 80 & 84 & 80 & 72 & 77 & 86 & 83 & 82 & 87 & 68 & 77 & 84 & 73 & 76 & 68 \\
\hline 1989 & Jul. & Low & 50 & 52 & 57 & 45 & 44 & 46 & 49 & 50 & 56 & 56 & 46 & 52 & 57 & 54 & 58 & 54 & 57 & 61 & 55 & 52 & 52 & 46 & 49 & 52 & 48 & 56 & 56 & 47 & 51 & 47 & 50 \\
\hline 989 & Aug. & High & 64 & 75 & 76 & 79 & 88 & 9 & 9 & 84 & 77 & 78 & 80 & 82 & 80 & 79 & 18 & 76 & 77 & 81 & 78 & 78 & 74 & 67 & 74 & 72 & 78 & b & 82 & 82 & 74 & 69 & 73 \\
\hline 1989 & Aug. & Low & 49 & 54 & 51 & b/ & 50 & 53 & 53 & $5 /$ & 55 & 49 & 45 & $4 y$ & 49 & 50 & 45 & 48 & 56 & 49 & 49 & 58 & 60 & $5 /$ & su & 51 & 47 & 50 & 49 & 54 & o1 & 3 & D \\
\hline 1989 & Sep. & High & 74 & 74 & 77 & 81 & 73 & 82 & 86 & 89 & 86 & 88 & 87 & 90 & 93 & 92 & 88 & 74 & 70 & 71 & 73 & 82 & 89 & 95 & 89 & 84 & 72 & 67 & 73 & 90 & 69 & 60 & \\
\hline 1989 & Sep. & Low & 40 & 47 & 41 & 4 & 49 & 42 & 44 & 47 & 49 & 41 & 42 & 43 & 41 & 46 & 43 & 45 & 48 & 37 & 37 & 39 & 44 & 47 & 47 & 50 & 51 & 2 & 56 & 47 & 54 & 47 & \\
\hline 1989 & Oct. & High & 65 & 69 & 70 & 65 & 72 & 70 & 67 & 74 & 77 & 72 & 69 & 69 & 67 & 62 & 63 & 64 & 73 & 62 & 61 & 65 & 57 & 65 & 58 & 55 & 59 & 77 & 55 & 53 & 58 & 52 & 64 \\
\hline 1989 & Oct. & Low & 49 & 42 & 36 & 31 & 43 & 46 & 45 & 47 & 45 & 46 & 38 & 47 & 50 & 36 & 32 & 34 & 35 & 41 & 51 & 48 & 51 & 49 & 44 & 44 & 42 & 46 & 39 & 35 & 30 & 29 & 33 \\
\hline 1989 & Nov. & High & 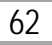 & 56 & 62 & 61 & 58 & 52 & 58 & 56 & 66 & 64 & 63 & 56 & 50 & 53 & 52 & 49 & 53 & 51 & 54 & 58 & 56 & 50 & 56 & 51 & 46 & 52 & 53 & 43 & 42 & 48 & \\
\hline 1989 & Nov. & L & 3 & 28 & 33 & 44 & 39 & 4 & 44 & 42 & 55 & 53 & 51 & 44 & 38 & 34 & 33 & 33 & 48 & 47 & 46 & 45 & 37 & 36 & 44 & 43 & 42 & 40 & 36 & 35 & 34 & 32 & \\
\hline 1989 & Dec. & High & 50 & 46 & 60 & 61 & 54 & 57 & 55 & 57 & 5 & 46 & 47 & 3 & 40 & 35 & 38 & 40 & 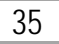 & 34 & 38 & 40 & 39 & 40 & 58 & 50 & 46 & 37 & 39 & 44 & 45 & 41 & 51 \\
\hline 1989 & Dec. & Low & 31 & 31 & 44 & 50 & 49 & 41 & 40 & 36 & 33 & 33 & 24 & 28 & 27 & 31 & 31 & 33 & 33 & 32 & 32 & 31 & 33 & 33 & 40 & 29 & 25 & 23 & 29 & 33 & 32 & 36 & 35 \\
\hline 1990 & Jan. & High & 48 & 50 & 48 & 50 & 55 & 55 & 59 & 58 & 61 & 45 & 49 & 48 & 50 & 50 & 47 & 47 & 49 & 47 & 49 & 46 & 47 & 51 & 47 & 43 & 46 & 45 & 51 & 48 & 47 & 45 & 42 \\
\hline 1990 & Jan. & L & 31 & 35 & 38 & 44 & 49 & 47 & 47 & 48 & 41 & 41 & 38 & 35 & 41 & 39 & 40 & 34 & 27 & 22 & 24 & 25 & 26 & 40 & 31 & 25 & 35 & 33 & 37 & 44 & 38 & 37 & 36 \\
\hline 1990 & Feb. & $\mathrm{H}$ & 49 & 52 & 49 & 47 & 44 & 39 & 40 & 48 & 51 & 5 & 48 & 38 & 37 & 34 & 35 & 39 & 42 & 45 & 47 & 47 & 58 & 51 & 53 & 58 & 64 & 65 & 68 & 68 & - & - & \\
\hline 1990 & Feb. & Low & 35 & 43 & 36 & 33 & 35 & 32 & 32 & 40 & 46 & 46 & 32 & 29 & 21 & 18 & 32 & 34 & 30 & 22 & 21 & 35 & 45 & 39 & 36 & 37 & 38 & 33 & 34 & 27 & - & - & \\
\hline 1990 & Mar. & High & 64 & 54 & 57 & 54 & 54 & 56 & 50 & 49 & 49 & 51 & 47 & 51 & 48 & 57 & 60 & 63 & 62 & 61 & 63 & 66 & 66 & 55 & 61 & 62 & 65 & 64 & 68 & 72 & 63 & 64 & 64 \\
\hline 990 & Mar. & $\mathrm{LC}$ & 27 & 31 & 41 & 36 & 34 & 45 & 38 & 34 & 39 & 35 & 33 & 31 & 27 & 37 & 32 & 40 & 47 & 4 & 48 & 45 & 35 & 44 & 41 & 38 & 33 & 33 & 30 & 34 & 35 & 33 & 40 \\
\hline 1990 & Apr. & High & 7 & 61 & 7. & 74 & 72 & 68 & 54 & 59 & 68 & 73 & 69 & 66 & 78 & 77 & & 63 & & 6 & 6 & 6 & & 57 & & 59 & 62 & & 55 & 58 & 9 & 8 & \\
\hline 1990 & Apr. & Low & 36 & 39 & $x$ & 36 & 36 & 35 & 34 & 36 & 30 & 36 & 41 & 34 & 38 & 43 & 48 & 49 & 50 & 48 & 47 & 50 & 47 & 47 & 45 & 41 & 38 & 38 & 39 & 39 & 39 & 32 & \\
\hline 1990 & May. & High & 72 & 72 & 76 & 86 & 78 & 62 & 61 & 67 & 77 & 58 & 59 & 63 & 64 & 64 & 65 & 70 & 61 & 60 & 68 & 61 & 63 & 65 & 60 & 63 & 69 & 70 & 73 & 66 & 64 & 64 & 65 \\
\hline 990 & May. & Lov & 38 & 47 & 50 & 45 & 41 & 36 & 36 & 31 & 39 & 41 & 47 & 46 & 42 & 38 & 44 & 38 & 48 & 45 & 39 & 49 & 48 & 50 & 42 & 42 & 35 & 50 & 56 & 51 & 50 & 46 & 47 \\
\hline 1990 & Jun. & High & 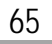 & 14 & 69 & 6 & 69 & 62 & 70 & 71 & 64 & 65 & 69 & 63 & 68 & 80 & 01 & 65 & 09 & 80 & 81 & os & 97 & 80 & 0 & 80 & 4 & 79 & 10 & 30 & 4 & 8 & \\
\hline 990 & Jun. & Low & 49 & 51 & 51 & 50 & 43 & 55 & 51 & 52 & 49 & 46 & 47 & 50 & 45 & 49 & 47 & 52 & 50 & 47 & 50 & 56 & 53 & 60 & 57 & 53 & 50 & 51 & 47 & 57 & 53 & 52 & \\
\hline
\end{tabular}


Appendix C1. Average Temperature Data for Willamette Valley by Month 1980-Present

\begin{tabular}{|c|c|c|c|c|c|c|c|c|c|c|c|c|c|c|c|c|c|c|c|c|c|c|c|c|c|c|c|c|c|c|c|c|c|}
\hline 990 & Jul. & tiah & 14 & 70 & 73 & 82 & 78 & 75 & 83 & 89 & 87 & 92 & 95 & 98 & 91 & 91 & 96 & 85 & 87 & 91 & 95 & 98 & 100 & 95 & 78 & 75 & 75 & 77 & 83 & 90 & 99 & 87 & \\
\hline 990 & Jul. & Low & 52 & 49 & 44 & 53 & 53 & 53 & 47 & 52 & 52 & 54 & 60 & 64 & 57 & 50 & 52 & 48 & 47 & 49 & 55 & 52 & 58 & 55 & 51 & 58 & 54 & 56 & 54 & 50 & 56 & 56 & 54 \\
\hline 990 & Aug. & High & 82 & 84 & 92 & 99 & 95 & 88 & 92 & 90 & 92 & 98 & 101 & 90 & 82 & 86 & 77 & 79 & 70 & 74 & 80 & 86 & 68 & 75 & 74 & 74 & 78 & 80 & 83 & 80 & 65 & 79 & \\
\hline 990 & Aug. & Low & 6 & 51 & 53 & 57 & 56 & 50 & 59 & 63 & 58 & 56 & 59 & 57 & 55 & 49 & 56 & 55 & 56 & 57 & 56 & 59 & 59 & 60 & 50 & 42 & 49 & 55 & 59 & 57 & 60 & 54 & \\
\hline 990 & Sep. & High & 79 & 78 & 84 & 92 & 85 & 87 & 78 & 81 & 82 & 88 & 67 & 71 & 87 & 79 & 67 & 75 & 75 & 79 & 75 & 85 & 95 & 95 & 76 & 70 & 73 & 73 & 76 & 82 & 76 & 75 & \\
\hline 1990 & Sep. & Low & 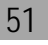 & 52 & 48 & 54 & 53 & 50 & 53 & 60 & 54 & 54 & 54 & 46 & 43 & 51 & 56 & 53 & 52 & 48 & 46 & 44 & 46 & 47 & 47 & 47 & 59 & 51 & 46 & 47 & 46 & 49 & \\
\hline 990 & Oct. & High & 69 & 63 & 73 & 74 & 63 & 60 & 61 & 66 & 68 & 61 & 62 & 65 & 61 & 55 & 67 & 60 & 61 & 58 & 57 & 56 & 54 & 56 & 61 & 63 & 66 & 60 & 67 & 62 & 63 & 53 & 4 \\
\hline 990 & ul. & Low & 44 & 44 & 52 & 50 & 38 & 34 & 30 & 32 & 35 & 36 & 31 & 50 & 43 & 39 & 51 & 36 & 36 & 40 & 38 & 36 & 38 & 37 & 40 & 41 & 41 & 43 & 43 & $\Delta 6$ & 40 & 50 & \\
\hline 990 & Nov. & High & 55 & 50 & 57 & 60 & 55 & 49 & 53 & 58 & 61 & 66 & 59 & 58 & 54 & 54 & 61 & 56 & 50 & 49 & 46 & 47 & 51 & 55 & 55 & 59 & 55 & 47 & 52 & 50 & 51 & 49 & \\
\hline 1990 & Nov. & Low & 34 & 34 & 45 & 45 & 37 & 37 & 43 & 49 & 56 & 43 & 36 & 38 & 45 & 38 & 34 & 32 & 39 & 28 & 29 & 38 & 43 & 48 & 51 & 54 & 36 & 34 & 35 & 35 & 39 & 35 & \\
\hline 990 & Dec. & High & 47 & 47 & 50 & 54 & 50 & 43 & 39 & 59 & 52 & 51 & 47 & 39 & 45 & 48 & 50 & 43 & 51 & 49 & 32 & 18 & 18 & 21 & 24 & 26 & 36 & 43 & 46 & 38 & 24 & 34 & 45 \\
\hline 990 & Dec. & Low & 38 & 40 & 41 & 38 & 32 & 33 & 34 & 35 & 48 & 37 & 32 & 33 & 34 & 33 & 29 & 28 & 41 & 29 & 12 & 9 & 8 & 7 & 11 & 10 & 25 & 36 & 31 & 19 & 14 & 11 & \\
\hline 991 & Jan. & High & 48 & 37 & 42 & 39 & 36 & 33 & 48 & 51 & 47 & 52 & 56 & 60 & 61 & 56 & 51 & 48 & 45 & 44 & 51 & 52 & 49 & 49 & 43 & 48 & 51 & 48 & 46 & 46 & 43 & 48 & \\
\hline 1991 & Jan. & Low & 31 & 28 & 24 & 20 & 18 & 29 & 32 & 29 & 29 & 46 & 48 & 53 & 46 & 48 & 38 & 34 & 35 & 37 & 34 & 30 & 27 & 25 & 26 & 27 & 25 & 22 & 19 & 30 & 22 & 24 & 34 \\
\hline 1991 & Feb. & High & 60 & 59 & 60 & 56 & 53 & 52 & 55 & 55 & 51 & 49 & 58 & 51 & 58 & 58 & 57 & 54 & 54 & 54 & 58 & 57 & 56 & 58 & 59 & 64 & 71 & 68 & 65 & 62 & - & - & \\
\hline 991 & Feb. & Low & 42 & 50 & 50 & 49 & 37 & 32 & 33 & 34 & 34 & 34 & 40 & 47 & 51 & 51 & 48 & 35 & 39 & 43 & 51 & 46 & 39 & 36 & 32 & 30 & 36 & 33 & 30 & $2 y$ & - & - & \\
\hline 1991 & Mar. & High & 59 & 51 & 57 & 49 & 47 & 50 & 50 & 54 & 53 & 49 & 46 & 55 & 53 & 50 & 52 & 58 & 64 & 53 & 53 & 55 & 51 & 50 & 51 & 54 & 50 & 58 & 60 & 55 & 60 & 68 & 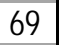 \\
\hline 1991 & Mar. & Low & 45 & 46 & 44 & 34 & 32 & 33 & 32 & 35 & 35 & 31 & 32 & 35 & 21 & 34 & 34 & 31 & 30 & 40 & 25 & 29 & 36 & 39 & 35 & 38 & 31 & 32 & 31 & 34 & 30 & 33 & 42 \\
\hline 1991 & Apr. & High & 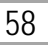 & 58 & 56 & 60 & 58 & 48 & 55 & 50 & 53 & 51 & 58 & 68 & 67 & 55 & 57 & 64 & 61 & 66 & 73 & 71 & 62 & 63 & 55 & 53 & 54 & 55 & 60 & 59 & 61 & 74 & \\
\hline 1991 & Apr. & Low & 46 & 44 & 45 & 51 & 35 & 33 & 38 & 36 & 40 & 35 & 29 & 2 & 35 & 44 & 39 & 39 & 38 & 43 & 36 & 48 & 43 & 40 & 42 & 40 & 39 & 40 & 38 & 36 & 31 & 36 & \\
\hline 1991 & May. & High & 14 & 72 & 67 & 70 & 57 & 66 & 58 & 55 & 58 & 56 & 59 & 58 & 63 & 65 & br & 72 & 50 & 55 & 55 & 65 & 68 & 64 & 12 & 64 & 60 & 64 & 63 & 66 & b/ & b3 & 08 \\
\hline 1991 & May. & Low & 40 & 41 & 39 & 35 & 48 & 51 & 48 & 38 & 37 & 45 & 49 & 49 & 47 & 32 & 40 & 44 & 45 & 46 & 49 & 50 & 45 & 42 & 41 & 42 & 42 & 48 & $\angle$ & 45 & 43 & 40 & 37 \\
\hline 1991 & Jun. & High & 74 & 74 & 64 & 67 & 68 & 67 & 69 & 73 & 83 & 84 & 71 & o & 65 & 70 & 65 & 65 & 72 & 81 & 61 & 54 & 60 & 68 & 73 & 66 & 65 & 70 & 77 & 68 & 66 & 71 & \\
\hline 1991 & Jun. & Low & 4 & 46 & 35 & 3. & 34 & 5 & 50 & 51 & 4 & 48 & 45 & 44 & 48 & 48 & 47 & 39 & 35 & 46 & 51 & 50 & 48 & 48 & 50 & 55 & 54 & 48 & 43 & 56 & 56 & 52 & \\
\hline 1991 & Jul. & High & 85 & 95 & 89 & 82 & 79 & 81 & 89 & 84 & 74 & 79 & 87 & 89 & 76 & 80 & 72 & 73 & 75 & 79 & 75 & 83 & 83 & 95 & 98 & 73 & 74 & 83 & 88 & 88 & 39 & 90 & 92 \\
\hline 1991 & Jul. & Low & ᄃ & 54 & 54 & $4 y$ & 51 & 46 & 50 & 48 & 47 & 56 & 50 & 5 & 56 & 49 & 54 & 5 & 57 & 48 & 52 & 44 & 47 & 56 & 63 & 59 & $5 /$ & 49 & 57 & 54 & 54 & 56 & 55 \\
\hline 1991 & Aug. & High & 80 & 85 & 88 & 85 & 79 & 85 & a & 91 & 76 & 74 & 82 & 0 & 86 & 89 & 88 & 82 & 90 & 87 & 91 & 93 & 91 & 88 & 73 & 76 & 74 & 79 & 5 & 65 & 89 & 33 & 00 \\
\hline 1991 & Aug. & Low & $4 c$ & 54 & 51 & 53 & 56 & 5 & 58 & 61 & 5 & 57 & 50 & 51 & 53 & 51 & 57 & 53 & 56 & 54 & 57 & 53 & 54 & 56 & 55 & 43 & 42 & 43 & 54 & 57 & 88 & 52 & 52 \\
\hline 1991 & Sep. & High & 73 & 80 & 92 & 9 & 93 & 87 & 72 & 70 & 81 & 83 & 79 & 81 & 74 & 75 & 87 & 90 & 95 & 93 & 89 & 72 & 73 & 83 & 34 & 95 & 94 & 82 & 68 & 72 & 77 & 85 & \\
\hline 1991 & Sep. & Low & 44 & 46 & 51 & 53 & 54 & 50 & 57 & 52 & 49 & 49 & 44 & 47 & 50 & 41 & 44 & 49 & 53 & 53 & 51 & 40 & 31 & 39 & 51 & 52 & 52 & 48 & 48 & 56 & 14 & 47 & \\
\hline 1991 & Oct. & High & 80 & 76 & 74 & 81 & 84 & 71 & 71 & 75 & 81 & 87 & 86 & 75 & 78 & 82 & 85 & 64 & 6 & 66 & 72 & 73 & 64 & 53 & 56 & 57 & $0 \perp$ & 51 & 54 & 47 & U & 51 & 53 \\
\hline 1991 & Oct. & Low & 46 & 43 & 4 & 40 & 41 & 47 & 45 & 37 & 39 & 42 & 41 & 46 & 40 & 42 & 39 & 44 & 33 & 40 & 38 & 45 & 40 & 44 & 42 & 46 & 47 & 39 & 34 & 38 & 33 & 27 & 29 \\
\hline 1991 & Nov. & High & 50 & 55 & 51 & 56 & 62 & 56 & 56 & 60 & 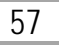 & 54 & 64 & 61 & 56 & 52 & 40 & 55 & 44 & 54 & 54 & 55 & 54 & 45 & 46 & 56 & 59 & 51 & 52 & 49 & 18 & 43 & \\
\hline 1991 & Nov. & Low & 40 & 40 & 39 & 45 & 55 & 50 & 51 & 48 & 42 & 45 & 50 & 51 & 41 & 32 & 32 & 36 & 44 & 45 & 48 & 42 & 32 & 31 & 33 & 44 & 50 & 40 & 35 & 36 & 28 & 27 & \\
\hline 1991 & Dec. & High & 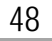 & 54 & 54 & 52 & 53 & 53 & 53 & 52 & $4 c$ & 41 & 48 & 5 & 42 & 40 & 37 & 35 & 37 & 45 & 48 & 36 & 46 & 47 & 46 & 47 & 46 & 46 & 49 & 48 & 14 & 47 & 43 \\
\hline 1991 & Dec. & Low & 42 & 38 & 38 & 4 & 48 & 4 & 42 & 40 & 3 & 31 & 37 & 3 & $x$ & 29 & 2 & $x$ & 27 & & 32 & 31 & 35 & 42 & & 42 & 39 & 36 & 41 & 37 & 0 & 36 & \\
\hline 1992 & Jan. & High & 45 & 50 & 51 & 52 & 46 & 46 & 44 & 45 & 46 & 49 & 51 & 3 & 45 & 50 & 50 & 52 & 50 & 52 & 48 & 44 & 54 & 54 & 57 & 60 & 56 & 53 & 57 & 58 & 3 & 55 & 61 \\
\hline 1992 & Jan. & Low & 37 & 40 & 41 & 41 & 40 & 38 & 27 & 27 & 31 & 31 & 30 & 28 & 36 & 42 & 43 & 39 & 32 & 29 & 23 & 22 & 37 & 36 & 50 & 42 & 37 & 34 & 45 & 49 & 51 & 47 & 47 \\
\hline 1992 & Feb. & High & 53 & 59 & 56 & 60 & 54 & 51 & 53 & 42 & 56 & 58 & 55 & 64 & 57 & 52 & $5 /$ & 51 & 52 & 52 & 49 & 53 & 62 & 59 & 55 & 64 & 08 & 67 & 66 & 62 & 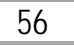 & - & \\
\hline 1992 & reo. & Low & 40 & 39 & 3 & 29 & 28 & 28 & 29 & 2 & 4 & 39 & 39 & 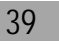 & 42 & 41 & 31 & 36 & & 45 & $4 \angle$ & 8 & 40 & 39 & I & 48 & 47 & & 37 & 36 & 9 & 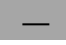 & \\
\hline 1992 & Mar. & High & $5 s$ & 55 & 64 & 53 & 61 & 58 & 57 & 64 & 64 & 66 & 64 & 68 & 63 & 67 & 62 & 58 & 99 & 59 & 64 & 66 & 70 & 67 & 68 & 64 & 69 & 57 & 58 & 59 & 0 & 67 & 0 \\
\hline 1992 & Mar. & Low & 40 & 37 & 39 & 42 & 43 & 42 & 44 & 34 & 30 & 32 & 33 & 34 & 35 & 43 & 39 & 46 & 38 & 32 & 34 & 31 & 34 & 35 & 36 & 34 & 40 & 45 & 42 & 38 & 38 & 44 & 38 \\
\hline
\end{tabular}


Appendix C1. Average Temperature Data for Willamette Valley by Month 1980-Present

\begin{tabular}{|c|c|c|c|c|c|c|c|c|c|c|c|c|c|c|c|c|c|c|c|c|c|c|c|c|c|c|c|c|c|c|c|c|c|}
\hline & & & & 2 & 3 & 4 & 5 & 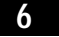 & 1 & 6 & $y$ & 10 & 11 & 12 & 13 & 14 & 15 & 16 & 18 & 18 & 19 & 20 & 21 & 22 & 23 & 24 & 25 & 26 & 24 & 28 & 29 & 50 & \\
\hline 392 & Apr. & High & 76 & 76 & 62 & 53 & 51 & 55 & 53 & 55 & 62 & 63 & 58 & 65 & 65 & 69 & 67 & 63 & 59 & 65 & 64 & 62 & 57 & 57 & 65 & 74 & 79 & 71 & 74 & 76 & 72 & 61 & \\
\hline 992 & Apr. & Low & 41 & 44 & 38 & 38 & 35 & 35 & 35 & 39 & 48 & 50 & 48 & 48 & 48 & 42 & 45 & 55 & 49 & 41 & 36 & 41 & 41 & 35 & 31 & 42 & 44 & 47 & 57 & 54 & 54 & 38 & \\
\hline 992 & May. & High & 66 & 75 & 86 & 85 & 87 & 88 & 81 & 63 & 65 & 65 & 62 & 67 & 78 & 79 & 77 & 83 & 85 & 76 & 72 & 65 & 69 & 80 & 86 & 92 & 78 & 76 & 73 & 76 & 78 & 83 & \\
\hline 1992 & May. & Low & 34 & 37 & 42 & 48 & 51 & 50 & 48 & 39 & 42 & 46 & 43 & 38 & 45 & 41 & 39 & 38 & 47 & 46 & 50 & 39 & 33 & 37 & 43 & 48 & 55 & 51 & 47 & 47 & 55 & 54 & 51 \\
\hline 992 & Jun. & High & 80 & 79 & 85 & 78 & 80 & 83 & 78 & 80 & 74 & 77 & 65 & 70 & 69 & 72 & 71 & 68 & 73 & 85 & 86 & 89 & 99 & 105 & 99 & 99 & 88 & 88 & 87 & 72 & 74 & 76 & \\
\hline 392 & Jun. & Low & 50 & 47 & 44 & 38 & 42 & 43 & 45 & 44 & 52 & 47 & 55 & 50 & 49 & 52 & 46 & 54 & 54 & 44 & 48 & 50 & 57 & 59 & 58 & 57 & 53 & 52 & 54 & 58 & 56 & 58 & \\
\hline 992 & Jul. & High & 74 & 82 & 83 & 72 & 73 & 76 & 76 & 77 & 80 & 81 & 78 & 86 & 81 & 78 & 87 & 99 & 99 & 94 & 90 & 78 & 76 & 68 & 73 & 77 & 91 & 88 & 90 & 90 & 91 & 100 & 37 \\
\hline 1992 & Jul. & Low & 51 & 50 & 54 & 54 & 51 & 58 & 52 & 56 & 49 & 53 & 55 & 54 & 52 & 56 & 51 & 57 & 59 & 62 & 54 & 55 & 62 & 54 & 57 & 59 & 51 & 53 & 55 & 55 & 53 & 57 & 57 \\
\hline 992 & Aug. & High & 79 & 85 & 85 & 74 & 85 & 69 & 71 & 79 & 86 & 99 & 105 & 88 & 100 & 95 & 90 & 88 & 95 & 89 & 89 & 86 & 73 & 68 & 78 & 85 & 91 & 92 & 90 & 82 & 85 & 82 & 73 \\
\hline 392 & Aug. & Low & 52 & 49 & 50 & 52 & 49 & 55 & 51 & 46 & 46 & 52 & 56 & 64 & 60 & 56 & 52 & 50 & 56 & 54 & 57 & 48 & 47 & 56 & 50 & 44 & 45 & 47 & 53 & 47 & 46 & 49 & \\
\hline 992 & Sep. & High & 82 & 85 & 83 & 70 & 71 & 70 & 73 & 73 & 82 & 85 & 72 & 68 & 68 & 61 & 62 & 73 & 75 & 80 & 78 & 81 & 83 & 88 & 73 & 63 & 69 & 74 & 72 & 79 & 83 & 80 & \\
\hline 1992 & Sep. & Low & 56 & 50 & 47 & 55 & 50 & 40 & 39 & 52 & 49 & 51 & 54 & 46 & 43 & 39 & 50 & 54 & 45 & 42 & 53 & 48 & 58 & 52 & 58 & 53 & 50 & 50 & 44 & 40 & 44 & 52 & \\
\hline 992 & Oct. & High & 68 & 58 & 66 & 63 & 67 & 75 & 72 & 67 & 69 & 74 & 76 & 75 & 65 & 60 & 60 & 59 & 67 & 67 & 75 & 59 & 63 & 73 & 75 & 69 & 64 & 63 & 63 & 60 & 60 & 54 & 59 \\
\hline 392 & Oct. & Low & 5 & 54 & 50 & 39 & 37 & 40 & 36 & 43 & 37 & 41 & 40 & 41 & 38 & 31 & 30 & 39 & 51 & 51 & 50 & 50 & 49 & 49 & 47 & 48 & 54 & 43 & 36 & 46 & 49 & 48 & \\
\hline 992 & Nov. & High & 59 & 59 & 57 & 58 & 51 & 61 & 61 & 54 & 54 & 43 & 52 & 53 & 55 & 48 & 49 & 51 & 58 & 53 & 50 & 50 & 53 & 52 & 46 & 48 & 49 & 47 & 57 & 49 & 39 & 50 & \\
\hline 1992 & Nov. & Low & 5 & 43 & 43 & 43 & 46 & 47 & 48 & 44 & 36 & 32 & 38 & 48 & 40 & 44 & 42 & 44 & 46 & 42 & 39 & 41 & 44 & 38 & 30 & 25 & 34 & 35 & 37 & 30 & 31 & 39 & \\
\hline 992 & Dec. & High & 42 & 46 & 47 & 44 & 37 & 38 & 39 & 49 & 47 & 50 & 45 & 49 & 48 & 50 & 48 & 42 & 38 & 39 & 45 & 47 & 51 & 50 & 46 & 49 & 40 & 48 & 47 & 47 & 41 & 42 & 36 \\
\hline 1992 & Dec. & Low & 39 & 33 & 29 & 28 & 19 & 31 & 30 & 38 & 38 & 32 & 31 & 36 & 34 & 37 & 31 & 30 & 30 & 27 & 38 & 39 & 42 & 43 & 31. & 31 & 35 & 39 & 40 & 41 & 31 & 30 & \\
\hline 1993 & Jan. & High & 35 & 36 & 42 & 44 & 38 & 34 & 33 & 30 & 37 & 35 & 30 & 36 & 35 & 36 & 44 & 36 & 42 & 46 & 47 & 52 & 45 & 48 & 43 & 56 & 63 & 60 & 50 & 50 & 53 & ל५ & 22 \\
\hline 1993 & Jan. & Low & 25 & 25 & 35 & 35 & 27 & 26 & 2 & 28 & 22 & 1 & 13 & 2 & 24 & 30 & 30 & 2 & 21 & 21 & 33 & 40 & 39 & 31 & 28 & 43 & 45 & 35 & 30 & 46 & 34 & 8 & 25 \\
\hline 993 & Feb. & High & 50 & 54 & 50 & 56 & 52 & 58 & 63 & 53 & 4 & 50 & 57 & 5 & 53 & 43 & 45 & 38 & 44 & 41 & 35 & 38 & 39 & 42 & 43 & 46 & 47 & 48 & 49 & 56 & - & - & \\
\hline 1993 & Feb. & Low & 26 & 38 & 36 & 28 & 36 & 35 & 30 & 38 & 36 & 36 & 38 & 4 & 33 & 28 & 28 & 25 & 23 & 31 & 29 & r & 33 & 29 & 25 & 23 & 20 & 24 & 20 & 22 & - & - & \\
\hline 993 & Mar. & High & 48 & 48 & 58 & 55 & 64 & 60 & 62 & 60 & 59 & 61 & 64 & 52 & 52 & 60 & 52 & 48 & 55 & 54 & 61 & 60 & 66 & 59 & 61 & 61 & 60 & 63 & 63 & 63 & 57 & 63 & 64 \\
\hline 1993 & Mar. & Low & 34 & 33 & 42 & 48 & 41 & 40 & 36 & 46 & 40 & 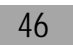 & 34 & 4 & 34 & 48 & 44 & 4 & 45 & 42 & 41 & 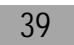 & - & 44 & 39 & 40 & 32 & 32 & 0 & 33 & 38 & 9 & 44 \\
\hline .993 & Apr. & High & 56 & 57 & 60 & 61 & 60 & 61 & $\alpha$ & 62 & כ & 54 & 57 & 60 & 59 & 64 & 60 & 63 & 60 & 61 & 68 & 68 & 65 & 56 & 57 & 64 & 57 & 61 & 64 & 62 & 68 & 66 & \\
\hline 1993 & Apr. & Low & $4 C$ & 48 & 47 & 42 & 41 & 45 & 43 & 49 & 45 & 43 & 35 & 30 & 38 & 36 & 45 & 42 & 47 & 39 & 34 & 44 & 47 & 47 & 48 & 49 & 46 & 47 & 42 & 45 & 51 & 45 & \\
\hline 993 & May. & High & 59 & 70 & 61 & 64 & 70 & 63 & 59 & 63 & 75 & 82 & 72 & 6 & 76 & 71 & 75 & 81 & 89 & 82 & 82 & 5 & 68 & 70 & 88 & 86 & 64 & 77 & 74 & 67 & 79 & 74 & 70 \\
\hline 1993 & May. & Low & 43 & 43 & 46 & 44 & 39 & 43 & 41 & 41 & 40 & 49 & 44 & 5 & 51 & 51 & 50 & 45 & 45 & 54 & 56 & 51 & 54 & 52 & 48 & 49 & 53 & 48 & 53 & 50 & 50 & 58 & 55 \\
\hline 393 & Jun. & $\mathrm{H}$ & 62 & 67 & 72 & 72 & 69 & 65 & 67 & 71 & 65 & 65 & 64 & 1 & 75 & 78 & 70 & 73 & 80 & 84 & 77 & 8 & 66 & cr & 7 & 81 & 88 & 7 & 2 & 72 & 75 & 79 & \\
\hline 1993 & Jun. & Low & 5 & 46 & 44 & 53 & 55 & 5 & 5 & 50 & 50 & 48 & 47 & 4 & 42 & 56 & 56 & 53 & $4 c$ & $4 C$ & 55 & 19 & 51 & 47 & 44 & 42 & 52 & 6 & 54 & 48 & 50 & 51 & \\
\hline 1993 & Jul. & High & 74 & 72 & 74 & 75 & 75 & 74 & 76 & 82 & 74 & 78 & 73 & 72 & 71 & 71 & 73 & 70 & 75 & 80 & 72 & 73 & 72 & 69 & 74 & 68 & 74 & 79 & 88 & 65 & 71 & 30 & 37 \\
\hline 1993 & Jul. & Low & 54 & 55 & 53 & 57 & 47 & 54 & 42 & 46 & 44 & 45 & 55 & 48 & 51 & 53 & 57 & 56 & 52 & 46 & 57 & 4 & 49 & 57 & 57 & 57 & 56 & 49 & 49 & 54 & 52 & 49 & 50 \\
\hline 1993 & Aug. & High & 0 & 97 & 100 & 98 & 91 & 82 & 76 & 79 & $7 \varepsilon$ & 79 & 80 & 74 & 71 & 70 & 75 & 72 & 8 & 87 & 83 & 7 & 78 & 00 & 7 & 71 & 11 & & 79 & 73 & 84 & 90 & 39 \\
\hline 1993 & Aug. & Low & 61 & 61 & $\infty$ & $5 c$ & 56 & 5 & 5 & 60 & 5 & 19 & 56 & 5 & $5 t$ & 59 & 58 & 51 & 46 & 51 & n & & 54 & 50 & & 44 & 12 & & 77 & 50 & 19 & 45 & \\
\hline 1993 & Sep. & High & 8 & 90 & 8 & 82 & 76 & 86 & 88 & 94 & 92 & 9 & 73 & 7 & 82 & 76 & 71 & 79 & 79 & 73 & 67 & 66 & 72 & 78 & 80 & 78 & 79 & 90 & 86 & 84 & 39 & 83 & \\
\hline 1993 & Sep. & Low & 48 & 48 & 50 & 48 & 56 & 51 & 53 & 55 & 52 & 52 & 45 & 50 & 47 & 44 & 47 & 44 & 44 & 40 & 40 & 40 & 35 & 35 & 36 & 39 & 44 & 43 & 45 & 43 & 47 & 48 & \\
\hline 1993 & Oct. & High & 85 & 85 & 84 & 78 & 68 & 61 & 67 & 73 & 80 & 72 & 69 & 68 & 70 & 61 & 63 & 65 & 63 & 62 & 67 & 68 & 67 & 68 & 71 & 63 & 68 & 75 & 67 & 72 & 73 & 72 & 63 \\
\hline 993 & Oct. & Low & 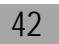 & 46 & 44 & 16 & $\Delta 6$ & 5 & 40 & 40 & 39 & 44 & 47 & 5 & - & & & 44 & & & 4 & & 45 & & & & 36 & & 31 & $\angle$ & & 7 & \\
\hline 1993 & Nov. & High & 57 & 60 & 65 & 60 & 58 & 59 & 51 & 42 & 55 & 59 & 49 & 50 & 54 & 52 & 4 & 48 & 0 & 50 & 47 & 40 & 48 & 44 & 36 & 37 & 40 & 10 & 44 & 42 & 54 & 51 & \\
\hline 1993 & Nov. & Low & 32 & 31 & 37 & 39 & 33 & 23 & 27 & 29 & 3. & 31 & 27 & 37 & 30 & 24 & 28 & 43 & 34 & 34 & 37 & 36 & 36 & 33 & 23 & 18 & 23 & 18 & 2 & 34 & 36 & 36 & \\
\hline 993 & Dec. & High & 61 & 53 & 57 & 53 & 41 & 49 & 50 & 51 & 64 & 68 & 50 & 50 & 50 & 51 & 50 & 41 & 43 & 44 & 45 & 44 & 44 & 34 & 37 & 38 & 2 & 36 & 43 & 12 & 12 & 49 & D \\
\hline 993 & Dec. & Low & 45 & 43 & 48 & 35 & 32 & 36 & 47 & 46 & 46 & 46 & 39 & 39 & 41 & 44 & 34 & 34 & 30 & 2 & 23 & $\mathbb{Z Z}$ & 27 & 25 & 29 & 29 & 29 & 30 & 21 & 27 & 29 & 31 & $4 \pi$ \\
\hline
\end{tabular}


Appendix C1. Average Temperature Data for Willamette Valley by Month 1980-Present

\begin{tabular}{|c|c|c|c|c|c|c|c|c|c|c|c|c|c|c|c|c|c|c|c|c|c|c|c|c|c|c|c|c|c|c|c|c|c|}
\hline & an. & & 60 & 57 & 59 & 56 & 52 & 5 & 56 & 54 & 5 & 51 & 55 & 56 & 50 & 50 & 58 & 53 & 40 & 39 & 37 & 42 & 50 & 51 & 58 & 49 & 43 & 40 & 43 & 54 & 53 & 57 & \\
\hline 1994 & Jan. & Low & 41 & 44 & 50 & 45 & 41 & 33 & 30 & 45 & 41 & 40 & 46 & 47 & 43 & 46 & 35 & 32 & 31 & 34 & 33 & 34 & 35 & 44 & 43 & 36 & 36 & 36 & 38 & 30 & 27 & 25 & 24 \\
\hline 1994 & Feb. & High & 52 & 49 & 49 & 46 & 50 & 46 & 44 & 43 & 51 & 49 & 52 & 50 & 50 & 55 & 56 & 51 & 48 & 49 & 56 & 52 & 47 & 49 & 53 & 50 & 53 & 58 & 54 & 62 & - & - & \\
\hline 994 & Feb. & Low & 25 & 23 & 21 & 24 & 21 & 24 & 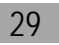 & 23 & 36 & 32 & 33 & 32 & 41 & 40 & 46 & 42 & 37 & 36 & 34 & 32 & 39 & 39 & 46 & 38 & 40 & 48 & 47 & 53 & - & - & \\
\hline 994 & Mar. & High & 67 & 57 & 66 & 59 & 54 & 59 & 61 & 61 & 67 & 58 & 58 & 67 & 70 & 70 & 63 & 55 & 55 & 52 & 53 & 54 & 52 & 48 & 54 & 66 & 68 & 74 & 77 & 75 & 74 & 58 & \\
\hline 994 & Mar. & Low & 51 & 52 & 51 & 41 & 34 & 32 & 30 & 32 & 38 & 42 & 34 & 31 & 40 & 37 & 34 & 44 & 45 & 37 & 37 & 40 & 37 & 36 & 36 & 41 & 34 & 32 & 35 & 38 & 35 & 50 & \\
\hline 1994 & Apr. & High & 61 & 62 & 60 & 59 & 52 & 58 & 55 & 57 & 59 & 62 & 70 & 62 & 58 & 61 & 76 & 78 & 74 & 74 & 70 & 74 & 67 & 66 & 63 & 62 & 67 & 64 & 65 & 70 & 59 & 64 & \\
\hline 1994 & Apr. & LOW & 43 & 42 & 40 & 39 & 33 & 44 & 44 & 47 & 47 & 42 & 36 & 38 & 37 & 36 & 38 & 44 & 47 & 48 & 44 & 40 & 46 & 38 & 42 & 47 & 47 & 47 & 45 & 40 & 43 & 39 & \\
\hline 994 & May. & High & 64 & 62 & 63 & 70 & 81 & 86 & 85 & 78 & 80 & 87 & 76 & 70 & 71 & 68 & 61 & 62 & 63 & 67 & 65 & 63 & 70 & 77 & 82 & 84 & 75 & 67 & 69 & 59 & 67 & 76 & \\
\hline 994 & May. & Low & 36 & 47 & 45 & 51 & 49 & 52 & 50 & 47 & 45 & 44 & 54 & 42 & 39 & 44 & 50 & 49 & 49 & 50 & 48 & 53 & 47 & 46 & 45 & 46 & 52 & 48 & 37 & 49 & 50 & 37 & \\
\hline 1994 & Jun. & High & 71 & 75 & 75 & 70 & 64 & 64 & 69 & 75 & 82 & 86 & 83 & 75 & 64 & 64 & 69 & 76 & 70 & 72 & 83 & 85 & 83 & 78 & 73 & 78 & 73 & 75 & 88 & 87 & 80 & 81 & \\
\hline 994 & Jun. & Low & 48 & 45 & 39 & 53 & 50 & 48 & 46 & 40 & 46 & 49 & 54 & 54 & 50 & 49 & 47 & 42 & 46 & 43 & 43 & 48 & 49 & 58 & 48 & 41 & 45 & 54 & 50 & 48 & 48 & 50 & \\
\hline 394 & Jul. & Hign & 76 & 74 & 74 & 70 & 76 & 82 & 93 & 90 & 87 & 87 & 90 & 88 & 88 & 82 & 82 & 93 & 91 & 86 & 100 & 103 & 103 & 100 & 97 & 76 & 87 & 90 & 93 & 87 & 79 & 80 & \\
\hline 994 & Jul. & Low & 47 & 51 & 44 & 46 & 51 & 45 & 55 & 51 & 45 & 42 & 43 & 43 & 46 & 46 & 55 & 51 & 48 & 58 & 54 & 60 & 59 & 65 & 61 & 55 & 56 & 50 & 53 & 52 & 53 & 55 & \\
\hline 1994 & Aug. & High & 88 & 90 & 87 & 78 & 80 & 84 & 72 & 74 & 82 & 88 & 85 & 86 & 87 & 82 & 81 & 82 & 81 & 81 & 79 & 79 & 76 & 79 & 80 & 80 & 83 & 33 & 91 & 80 & 78 & 85 & 3 \\
\hline 394 & Aug. & Low & 50 & 53 & 55 & 55 & 53 & 49 & 52 & 54 & 53 & 51 & 52 & 52 & 52 & 54 & 52 & 53 & 53 & 51 & 57 & 53 & 52 & 56 & 53 & 47 & 48 & 50 & 50 & 55 & 50 & 46 & 51 \\
\hline 994 & Sep. & High & 76 & 75 & 14 & 77 & 88 & 87 & 84 & 66 & 68 & 68 & 71 & 16 & 77 & 77 & 83 & 93 & 85 & 83 & 84 & 87 & 95 & 95 & 60 & 16 & 85 & 82 & 85 & 10 & 65 & 71 & \\
\hline 1994 & Sep. & Low & 47 & 43 & 51 & 52 & 47 & 51 & 48 & 57 & 52 & 50 & 49 & 44 & 45 & 52 & 49 & 50 & 56 & 52 & 52 & 54 & 56 & 50 & 48 & 48 & 48 & 52 & 49 & 56 & 57 & 55 & \\
\hline 1994 & Oct. & High & 76 & 69 & 72 & 75 & 74 & 69 & 68 & 76 & 76 & 61 & 64 & 64 & 61 & 59 & 61 & 61 & 55 & 60 & 66 & 64 & 64 & 60 & 63 & 69 & 65 & 61 & 60 & 61 & 48 & 55 & \\
\hline 994 & Oct. & Low & 57 & 45 & 41 & 42 & 38 & 46 & 40 & 39 & 44 & 43 & 32 & 39 & 35 & 41 & 38 & 34 & 37 & 34 & 42 & 50 & 41 & 34 & 38 & 36 & 36 & 57 & 50 & 39 & 35 & 43 & 44 \\
\hline 994 & Nov. & High & 52 & 50 & 44 & 46 & 51 & 5 & 53 & 49 & 54 & 45 & 45 & 52 & 51 & 54 & 50 & 46 & 43 & 38 & 47 & 50 & 34 & 44 & 46 & 50 & 47 & 4 & 51 & 49 & 54 & 56 & \\
\hline 1994 & Nov. & Low & 38 & 34 & 33 & 34 & 30 & 31 & 36 & 32 & 35 & 32 & 40 & 31 & 40 & 36 & 43 & 31 & 29 & 25 & 31 & 28 & 24 & 30 & 41 & 41 & 36 & 34 & 31 & 37 & 43 & 48 & \\
\hline 1994 & Dec. & High & 52 & 45 & 40 & 39 & 36 & 41 & 47 & 42 & 51 & 46 & 45 & 48 & 40 & 45 & 49 & 56 & 58 & 53 & 62 & 63 & 48 & 46 & 43 & 52 & 50 & 57 & 58 & 51 & 43 & 50 & \\
\hline 994 & Dec. & LC & 43 & 33 & 29 & 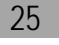 & 25 & 30 & $u$ & 28 & 31 & 33 & 38 & 30 & 26 & 34 & 41 & 48 & 48 & 47 & 49 & 47 & 41 & 41 & 39 & 40 & 36 & 49 & 46 & 29 & 26 & 28 & 26 \\
\hline 1995 & Jan. & High & 43 & 45 & 46 & 45 & 38 & $4 c$ & 44 & 56 & 5 & 56 & 50 & 54 & 55 & 52 & 47 & 50 & 48 & 51 & 53 & 59 & 56 & 51 & 22 & 53 & 49 & 2 & 51 & 48 & 59 & 62 & 62 \\
\hline 1995 & Jan. & Low & 33 & 31 & 32 & 29 & 30 & 34 & 35 & 39 & 45 & 46 & 43 & 43 & 47 & 44 & 42 & 33 & 33 & 35 & 35 & 32 & 30 & 35 & 31 & 30 & 32 & 35 & 38 & 43 & 45 & 52 & 56 \\
\hline 1995 & Feb. & High & 58 & 53 & 59 & 57 & 56 & 56 & 58 & 62 & 60 & 52 & 55 & 46 & 30 & 36 & 44 & 49 & 53 & 65 & 67 & 64 & 62 & 55 & 63 & 57 & $5 /$ & 55 & b/ & 57 & - & - & \\
\hline 995 & Feb. & & 46 & 39 & 42 & $3 s$ & 42 & 43 & 40 & 34 & 30 & 30 & 44 & 27 & 25 & 18 & 35 & 41 & 46 & 49 & 53 & 46 & 44 & 39 & 34 & 37 & 41 & 6 & 29 & 31 & - & + & \\
\hline 995 & Mar. & Higl & 56 & 58 & 49 & 47 & 51 & 52 & 55 & 55 & 66 & 54 & 61 & 56 & 60 & 61 & 61 & 63 & 61 & 59 & 53 & 53 & 49 & 53 & 55 & 51 & 52 & 59 & 66 & 71 & 72 & 75 & 60 \\
\hline 1995 & Mar. & Low & 25 & 35 & 39 & 39 & 32 & 29 & 26 & 43 & 49 & 44 & 45 & 40 & 48 & 42 & 43 & 33 & 43 & 44 & 39 & 43 & 34 & 34 & 30 & 38 & 33 & 29 & 31 & 31 & 30 & 34 & 41 \\
\hline 1995 & Apr. & High & 62 & 63 & 74 & 56 & 55 & 63 & 55 & 49 & 55 & 57 & 60 & bl & 55 & 54 & 60 & 66 & 53 & 54 & 53 & 53 & 60 & 71 & 75 & 77 & 71 & 60 & 53 & 65 & 64 & 68 & \\
\hline 995 & Apr. & Lc & 36 & 32 & 37 & 35 & 41 & 4 & 44 & 42 & 38 & 38 & 44 & 45 & 40 & 36 & 37 & 32 & 42 & 35 & 33 & 40 & 37 & 32 & 38 & 41 & 37 & 41 & 39 & 46 & 46 & $4 \pi$ & \\
\hline 1995 & ay. & $\mathrm{Hi}$ & 60 & 64 & 66 & 64 & 59 & 62 & 61 & 70 & 62 & 61 & 61 & 63 & 72 & 81 & 79 & 67 & 59 & 64 & 76 & 83 & 78 & 81 & 75 & 81 & 83 & 84 & 76 & 87 & 0 & 82 & \\
\hline 1995 & May. & Low & 52 & 45 & 41 & 50 & 47 & 49 & 49 & 41 & 49 & 46 & 45 & 46 & 41 & 40 & 47 & 53 & 49 & 43 & 37 & 42 & 44 & 49 & 44 & 43 & 47 & 13 & 46 & 47 & 51 & 48 & 51 \\
\hline 1995 & Jun. & High & 84 & 77 & 79 & 71 & 61 & 60 & 73 & 81 & 82 & 66 & 71 & 69 & 59 & 65 & 67 & 68 & 70 & 61 & 68 & 66 & 69 & 79 & 87 & 86 & 85 & 86 & 92 & 93 & 97 & 98 & \\
\hline 995 & Jun. & LoV & $\pi$ & 46 & 46 & 49 & 45 & 47 & 47 & 44 & $4 \varepsilon$ & 43 & 38 & 5 & 53 & 54 & 53 & 53 & 53 & 51 & b1 & 52 & 49 & 46 & 51 & 53 & 53 & 49 & 22 & 49 & 51 & 56 & \\
\hline 1995 & Jul. & rily & 9 & 76 & 7 & 80 & 79 & 7 & 7 & 86 & 68 & 74 & 78 & 7 & 76 & 78 & 8 & 95 & 101 & & 95 & & & 7 & & & & 4 & 85 & 83 & 74 & & \\
\hline 1995 & Jul. & Low & 53 & 55 & 57 & 57 & 58 & 51 & 58 & 59 & 52 & 49 & 50 & 47 & 48 & 53 & 50 & 59 & 62 & 61 & 62 & 58 & 54 & 61 & 62 & 60 & 52 & 11 & 60 & 54 & 50 & 46 & \\
\hline 1995 & Aug. & High & 89 & 83 & 86 & 94 & 85 & 78 & 70 & 76 & 85 & 68 & 78 & 74 & 77 & 85 & 72 & 65 & 69 & 76 & 84 & 90 & 80 & 82 & 76 & 75 & 79 & 76 & 79 & 75 & 72 & 78 & 35 \\
\hline 395 & Aug. & Lov & 55 & 55 & 53 & 61 & 54 & 56 & 53 & 50 & 52 & 55 & 53 & 51 & 46 & 47 & 59 & 53 & $4 \varepsilon$ & 45 & 46 & 52 & 50 & 49 & 53 & 45 & 46 & 46 & 46 & 5 & 57 & 52 & 50 \\
\hline 995 & sep. & Higr & 8 & 71 & 68 & 10 & $/ 4$ & 68 & $r_{c}$ & 81 & 86 & 84 & 82 & 84 & 86 & 88 & 79 & $6 /$ & 70 & 76 & 82 & 81 & 86 & 87 & ou & 10 & U & 34 & 10 & 66 & 67 & 68 & \\
\hline 995 & Sep. & Low & 53 & 54 & 54 & 51 & 57 & 53 & 54 & 53 & 53 & 54 & 54 & 54 & 50 & 53 & 53 & 58 & 60 & 48 & 48 & 53 & 45 & 43 & 46 & 49 & 53 & 53 & 58 & 55 & 55 & 48 & \\
\hline
\end{tabular}


Appendix C1. Average Temperature Data for Willamette Valley by Month 1980-Present

\begin{tabular}{|c|c|c|c|c|c|c|c|c|c|c|c|c|c|c|c|c|c|c|c|c|c|c|c|c|c|c|c|c|c|c|c|c|c|}
\hline 99 & Oct. & High & 06 & 70 & 64 & 66 & 70 & 65 & 67 & 60 & 66 & 64 & 61 & 61 & 64 & 71 & 73 & 65 & 59 & 61 & 71 & 61 & 59 & 53 & 56 & 55 & 55 & 62 & 61 & 60 & 58 & 56 & \\
\hline 1995 & Oct. & Low & 41 & 50 & 48 & 46 & 39 & 46 & 41 & 47 & 48 & 54 & 48 & 41 & 38 & 40 & 42 & 48 & 44 & 36 & 32 & 46 & 41 & 35 & 40 & 49 & 49 & 49 & 39 & 38 & 37 & 34 & 4 \\
\hline 1995 & Nov. & High & 58 & 54 & 57 & 52 & 51 & 52 & 59 & 60 & 51 & 57 & 57 & 57 & 67 & 64 & 59 & 62 & 61 & 60 & 57 & 58 & 57 & 60 & 59 & 62 & 56 & 52 & 56 & 58 & 57 & 54 & \\
\hline 995 & Nov. & Low & 28 & 26 & 25 & 28 & 44 & 45 & 02 & 47 & 42 & 43 & 48 & 48 & 52 & 53 & 54 & 51 & 51 & 42 & 38 & 34 & 40 & 50 & 52 & 53 & 43 & 44 & 47 & 55 & 53 & 2 & \\
\hline 995 & Dec. & High & 53 & 51 & 53 & 48 & 44 & 42 & 47 & 40 & 36 & 58 & 55 & 61 & 50 & 50 & 47 & 49 & 44 & 43 & 47 & 47 & 48 & 49 & 47 & 45 & 43 & 40 & 40 & 49 & 55 & - & \\
\hline 995 & Dec. & Low & 45 & 38 & 37 & 38 & 31 & 29 & 38 & 30 & 30 & 35 & 50 & 48 & 45 & 43 & 35 & 39 & 38 & 39 & 42 & 40 & 30 & 25 & 25 & 22 & 22 & 24 & 35 & 32 & 48 & 52 & \\
\hline 1996 & Jan. & High & 51 & 57 & 52 & 49 & 50 & 58 & 55 & 56 & 52 & 53 & 41 & 41 & 47 & 53 & 54 & 50 & 46 & 48 & 49 & 46 & 45 & 41 & 44 & 41 & 45 & 43 & 37 & 43 & 40 & 32 & \\
\hline 996 & Jan. & Low & 42 & 46 & 38 & 39 & 43 & 49 & 50 & 47 & 38 & 36 & 36 & 37 & 37 & 45 & 47 & 34 & 32 & 31 & 42 & 41 & 33 & 33 & 37 & 35 & 34 & 35 & 33 & 35 & 23 & 19 & \\
\hline 996 & Feb. & High & 35 & 35 & 28 & 35 & 55 & 57 & 61 & 62 & 50 & 59 & 59 & 60 & 62 & 61 & 64 & 55 & 57 & 58 & 56 & 56 & 44 & 47 & 41 & 45 & 38 & 41 & 46 & 50 & 56 & & \\
\hline 996 & Feb. & Low & 17 & 15 & 17 & 27 & 32 & 48 & 52 & 50 & 37 & 34 & 33 & 31 & 31 & 30 & 31 & 36 & 47 & 46 & 44 & 39 & 35 & 34 & 35 & 33 & 29 & 24 & 24 & 32 & 30 & 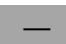 & \\
\hline 1996 & Mar. & High & 57 & 57 & 59 & 49 & 62 & 59 & 54 & 60 & 58 & 61 & 54 & 54 & 61 & 67 & 57 & 59 & 61 & 69 & 56 & 58 & 55 & 50 & 55 & 49 & 55 & 62 & 48 & 58 & 53 & 56 & 84 \\
\hline 996 & Mar. & Low & 27 & 27 & 44 & 38 & 42 & 45 & 46 & 45 & 46 & 49 & 45 & 45 & 40 & 36 & 39 & 31 & 39 & 34 & 36 & 34 & 33 & 37 & 39 & 35 & 27 & 25 & 31 & 30 & 35 & 36 & 45 \\
\hline 996 & Apr. & High & 62 & 54 & 61 & 68 & 73 & 76 & 78 & 72 & 62 & 55 & 52 & 52 & 62 & 71 & 65 & 54 & 53 & 53 & 52 & 53 & 56 & 58 & 61 & 59 & 61 & 58 & 59 & 68 & 70 & 68 & \\
\hline 1996 & Apr. & Low & 48 & 42 & 34 & 35 & 42 & 46 & 49 & 50 & 48 & 44 & 44 & 42 & 41 & 38 & 48 & 40 & 37 & 39 & 40 & 41 & 41 & 49 & 50 & 45 & 39 & 37 & 38 & 33 & 44 & 41 & \\
\hline 1996 & May. & High & 62 & 55 & 52 & 60 & 65 & 64 & 57 & 59 & 60 & 62 & 65 & 66 & 64 & 65 & 65 & 66 & 62 & 62 & 62 & 64 & 56 & 59 & 59 & 72 & 78 & 67 & 63 & 60 & 60 & 63 & 0 \\
\hline 996 & May. & Low & 46 & 36 & 36 & 32 & 36 & 36 & 35 & 31 & 34 & 42 & 46 & 52 & 55 & 54 & 52 & 47 & 51 & 48 & 44 & 40 & 48 & 45 & 47 & 44 & 46 & 49 & 39 & 46 & 47 & 45 & 41 \\
\hline 996 & Jun. & High & 80 & 87 & 78 & 69 & 77 & 84 & 73 & 72 & 68 & 74 & 71 & 79 & 73 & 75 & 72 & 68 & 62 & 68 & 80 & 76 & 69 & 71 & 69 & 65 & 73 & 78 & 69 & 68 & 77 & 82 & \\
\hline 1996 & Jun. & Low & 50 & 53 & 51 & 50 & 50 & 48 & 52 & 49 & 49 & 43 & 47 & 43 & 47 & 45 & 43 & 45 & 42 & 45 & 47 & 46 & 47 & 47 & 53 & 52 & 51 & 47 & 56 & 53 & 46 & 48 & \\
\hline 1996 & Jul. & High & 86 & 83 & 79 & 72 & 77 & 86 & 94 & 86 & 76 & 82 & 90 & 96 & 99 & 98 & 85 & 78 & 59 & 67 & 73 & 76 & 82 & 96 & 98 & 95 & 95 & 95 & 92 & 80 & 91 & 85 & \\
\hline 1996 & Jul. & Low & 51 & 56 & 54 & 52 & 42 & 52 & 54 & 56 & 55 & 49 & 53 & 57 & 60 & 62 & 56 & 50 & 54 & 52 & 55 & 52 & 58 & 59 & 62 & 62 & 56 & 59 & 60 & 62 & 59 & 58 & 52 \\
\hline 996 & Aug. & High & 79 & 71 & 74 & 73 & 73 & 8. & 92 & 95 & 97 & 99 & 75 & 87 & 92 & 0 & 85 & 82 & 74 & 70 & 77 & 76 & 83 & 92 & 5 & 94 & 81 & 72 & 3 & 83 & 91 & 80 & 77 \\
\hline 1996 & Aug. & Low & 49 & 55 & 54 & 52 & 55 & 47 & 53 & 57 & 56 & 58 & 51 & 54 & 56 & 54 & 49 & 52 & 46 & 45 & 45 & 54 & 49 & 51 & 52 & 58 & 61 & 60 & 55 & 50 & 54 & 56 & 50 \\
\hline 1996 & Sep. & High & 78 & 73 & 75 & 66 & 69 & 74 & 81 & 81 & 78 & 85 & 82 & 66 & 66 & 61 & 66 & 64 & 66 & 66 & 68 & 66 & 65 & 64 & 73 & 72 & 74 & 79 & 82 & 82 & 78 & 70 & \\
\hline 996 & Sep. & Low & 47 & 46 & 48 & 4 & 45 & 45 & 48 & 50 & 55 & 48 & 53 & 54 & 56 & 56 & 50 & 50 & 48 & 43 & 51 & 45 & 41 & 42 & 41 & 41 & 39 & 45 & 46 & 49 & 47 & 52 & \\
\hline 1996 & Oct. & High & 72 & 72 & 76 & 74 & 65 & 70 & 78 & 80 & 81 & 67 & 65 & 61 & 62 & 57 & 58 & 53 & 58 & 53 & 51 & 55 & 54 & 55 & 56 & 59 & 56 & 50 & 56 & 50 & 53 & 62 & 58 \\
\hline 1996 & Oct. & Low & 49 & 46 & 51 & 57 & 49 & 46 & 48 & 54 & 51 & 54 & 54 & 49 & 46 & 47 & 41 & 37 & 32 & 41 & 38 & 36 & 33 & 43 & 41 & 45 & 38 & 33 & 33 & 37 & 37 & 34 & 33 \\
\hline 1996 & Nov. & High & 58 & 56 & 57 & 51 & 52 & 53 & 53 & 59 & 49 & 50 & 58 & 62 & 56 & 53 & 52 & 50 & 53 & 46 & 46 & 51 & 40 & 43 & 40 & 57 & 53 & 45 & 56 & 52 & 48 & 54 & \\
\hline 1996 & Nov. & L & 30 & 32 & 43 & 36 & 34 & 37 & 39 & 38 & 36 & 40 & 41 & 50 & 45 & 44 & 42 & 44 & 45 & 34 & 35 & 34 & 37 & 27 & 27 & 39 & 39 & 40 & 45 & 40 & 40 & 45 & \\
\hline 1996 & Dec. & High & 48 & 44 & 55 & 54 & 47 & 4 & 51 & $4 \varepsilon$ & 50 & 52 & 46 & 49 & 51 & 41 & 40 & 43 & 47 & 41 & 46 & 50 & 42 & 44 & 47 & 51 & 53 & 3 & 49 & 38 & 56 & 54 & 65 \\
\hline 1996 & Dec. & Low & 37 & 37 & 30 & 35 & 40 & 40 & 41 & 43 & 39 & 41 & 39 & 42 & 35 & 29 & 34 & 33 & 31 & 27 & 23 & 38 & 39 & 32 & 38 & 46 & 36 & 34 & 37 & 29 & 33 & 46 & 49 \\
\hline 1997 & Jan. & High & 58 & 56 & 49 & 39 & 42 & 43 & 49 & 48 & 51 & 55 & 47 & 40 & 39 & 40 & 42 & 38 & 43 & 49 & 49 & 51 & 46 & 48 & 46 & 45 & 39 & 43 & 38 & 49 & 53 & 56 & b/ \\
\hline 1997 & Jan. & L & 52 & 43 & 35 & 30 & 36 & 37 & 36 & 37 & 4. & 41 & 38 & 27 & 10 & 19 & 19 & 29 & 35 & 38 & 41 & 43 & 38 & 31 & 32 & 34 & 34 & 29 & 28 & 35 & 35 & 49 & 48 \\
\hline 1997 & Feb. & $\mathrm{Hi}$ & 5 & 49 & 45 & 5 & 49 & 44 & 39 & 44 & 45 & 50 & 47 & 50 & 49 & 60 & 54 & 57 & 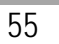 & 52 & 52 & 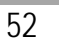 & 51 & 57 & 59 & 63 & 52 & 49 & 46 & 49 & 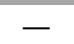 & - & \\
\hline 1997 & Feb. & Low & 43 & 32 & 32 & 33 & 27 & 24 & 35 & 32 & 28 & 28 & 29 & 38 & 38 & 48 & 33 & 37 & 39 & 39 & 39 & 36 & 33 & 27 & 28 & 31 & 34 & 41 & 32 & 34 & - & - & \\
\hline 1997 & Mar. & High & 48 & 44 & 45 & 48 & 46 & 52 & 51 & 51 & 55 & 47 & 49 & 48 & 51 & 51 & 57 & 53 & 60 & 61 & 59 & 59 & 60 & 62 & 59 & 65 & 72 & 58 & 54 & 55 & 58 & 58 & 49 \\
\hline 1997 & Mar. & Lon & 41 & 37 & 34 & 35 & 35 & 45 & 38 & 29 & 47 & 40 & 39 & 36 & 34 & 36 & 41 & 48 & 45 & 46 & 53 & 39 & 32 & 38 & 44 & 36 & 39 & 36 & 32 & 32 & 30 & 37 & 31 \\
\hline 1997 & Apr. & High & 5 & 59 & 5 & 56 & 62 & 6 & 55 & 56 & 5 & 56 & 61 & 58 & 53 & 57 & 7 & 66 & 62 & 56 & 60 & 60 & 5 & 01 & & 59 & 71 & 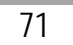 & & 54 & 61 & & \\
\hline 1997 & Apr. & Low & 33 & 29 & 3 & 29 & 30 & 29 & 45 & 35 & 30 & 37 & 32 & 30 & 47 & 49 & 47 & 42 & 37 & 48 & 53 & 47 & 37 & 48 & 42 & 40 & 40 & 46 & 38 & 47 & 44 & 39 & \\
\hline 1997 & May. & High & 58 & 66 & 58 & 67 & 69 & 63 & 73 & 77 & 76 & 83 & 91 & 81 & 83 & 79 & 78 & 82 & 81 & 82 & 80 & 68 & 71 & 67 & 64 & 63 & 62 & 74 & 75 & 69 & 77 & 77 & 68 \\
\hline 997 & May. & LoV & 38 & 35 & $4 c$ & 49 & 50 & 45 & 40 & 42 & 45 & 49 & 51 & 50 & 46 & 54 & 57 & 51 & 50 & 45 & 45 & 41 & 42 & 42 & 46 & 42 & 41 & 41 & 60 & 60 & 62 & 11 & 52 \\
\hline 97 & Jun. & High & 66 & 75 & 68 & 65 & 69 & 74 & $6 \varsigma$ & 72 & 80 & 79 & 65 & 67 & 74 & 75 & 82 & 82 & (1 & 72 & 71 & 16 & 63 & 5 & o/ & 13 & 74 & 72 & 73 & 69 & 74 & 71 & \\
\hline 997 & Jun. & Low & 49 & 45 & 54 & 48 & 44 & 45 & 52 & 48 & 46 & 50 & 4 & & 47 & 48 & & 54 & & 54 & 45 & 44 & 52 & 50 & & 44 & 49 & 48 & 48 & 52 & 49 & 52 & \\
\hline
\end{tabular}


Appendix C1. Average Temperature Data for Willamette Valley by Month 1980-Present

\begin{tabular}{|c|c|c|c|c|c|c|c|c|c|c|c|c|c|c|c|c|c|c|c|c|c|c|c|c|c|c|c|c|c|c|c|c|c|}
\hline 199 & Jul. & Int & 71 & 78 & 88 & 90 & 79 & 79 & 80 & 75 & 69 & 70 & 74 & 77 & 83 & 85 & 80 & 83 & 75 & 79 & 88 & 88 & 75 & 80 & 83 & 83 & 81 & 84 & 89 & 87 & 80 & 81 & \\
\hline 1997 & Jul. & Low & 53 & 47 & 53 & 57 & 57 & 58 & 49 & 58 & 51 & 52 & 55 & 49 & 52 & 56 & 55 & 55 & 56 & 54 & 51 & 57 & 53 & 51 & 52 & 51 & 52 & 49 & 53 & 55 & 55 & 57 & 51 \\
\hline 997 & Aug. & High & 85 & 83 & 87 & 88 & 91 & 91 & 87 & 81 & 91 & 92 & 91 & 96 & 91 & 94 & 76 & 92 & 78 & 75 & 87 & 70 & 82 & 83 & 82 & 77 & 80 & 74 & 77 & 77 & 79 & 80 & 30 \\
\hline 997 & A & Low & 50 & 52 & 54 & 55 & 59 & $?$ & 54 & 52 & 54 & 56 & 53 & 55 & 58 & 56 & 53 & 54 & 59 & 56 & 54 & 61 & 61 & 55 & 55 & 59 & 60 & 56 & 56 & 58 & 57 & 51 & \\
\hline 997 & Sep. & High & 30 & 83 & 81 & 80 & 75 & 77 & 82 & 93 & 82 & 74 & 71 & 72 & 65 & 73 & 61 & 64 & 68 & 68 & 76 & 81 & 82 & 81 & 86 & 88 & 79 & 65 & 69 & 74 & 75 & 66 & \\
\hline 1997 & Sep. & Low & 61 & 54 & 58 & 57 & 55 & 47 & 46 & 51 & 57 & 60 & 57 & 51 & 49 & 57 & 54 & 56 & 55 & 48 & 46 & 45 & 45 & 49 & 50 & 54 & 54 & 54 & 50 & 46 & 53 & 56 & \\
\hline 997 & Oct. & High & 62 & 66 & 63 & 62 & 61 & 60 & 59 & 58 & 54 & 55 & 57 & 58 & 60 & 65 & 69 & 66 & 64 & 57 & 59 & 63 & 60 & 59 & 58 & 54 & 57 & 56 & 58 & 54 & 59 & 62 & 22 \\
\hline 997 & Oct. & Low & 52 & 53 & 54 & 54 & 46 & 44 & 40 & 50 & 47 & 46 & 40 & 49 & 42 & 39 & 44 & 45 & 50 & 46 & 42 & 35 & 34 & 36 & 42 & 35 & 34 & 36 & 41 & 42 & 51 & 52 & \\
\hline 997 & Nov. & High & 61 & 57 & 62 & 61 & 63 & 61 & 55 & 47 & 62 & 60 & 55 & 58 & 52 & 58 & 57 & 53 & 55 & 49 & 51 & 54 & 56 & 49 & 56 & 53 & 56 & 54 & 54 & 57 & 50 & 50 & \\
\hline 1997 & Nov. & Low & 39 & 36 & 39 & 49 & 51 & 50 & 40 & 37 & 33 & 40 & 41 & 38 & 33 & 37 & 31 & 35 & 43 & 36 & 48 & 46 & 43 & 44 & 47 & 45 & 38 & 34 & 36 & 47 & 41 & 37 & \\
\hline 997 & Dec. & High & 49 & 54 & 49 & 50 & 47 & 46 & 45 & 45 & 45 & 51 & 39 & 39 & 37 & 49 & 49 & 54 & 51 & 37 & 47 & 47 & 47 & 34 & 45 & 41 & 38 & 45 & 49 & 52 & 47 & 45 & 50 \\
\hline 997 & Dec. & Low & 33 & 26 & 27 & 34 & 32 & 28 & 32 & 32 & 36 & 32 & 32 & 30 & 29 & 33 & 35 & 46 & 35 & 29 & 30 & 32 & 29 & 26 & 33 & 38 & 35 & 34 & 41 & 37 & 39 & 34 & \\
\hline 998 & Jan. & High & 50 & 44 & 43 & 47 & 46 & 47 & 49 & 38 & 38 & 39 & 38 & 45 & 51 & 51 & 52 & 56 & 55 & 53 & 47 & 51 & 48 & 51 & 55 & 50 & 53 & 53 & 55 & 54 & 56 & 57 & \\
\hline 1998 & Jan. & Low & 40 & 28 & 34 & 36 & 41 & 43 & 29 & 28 & 27 & 35 & 30 & 26 & 44 & 44 & 39 & 43 & 48 & 44 & 43 & 38 & 37 & 44 & 46 & 45 & 41 & 47 & 43 & 42 & 43 & 37 & 21 \\
\hline 998 & Feb. & High & 53 & 55 & 53 & 56 & 56 & 67 & 52 & 50 & 50 & 49 & 52 & 54 & 55 & 53 & 53 & 51 & 56 & 57 & 51 & 48 & 48 & 50 & 52 & 50 & 49 & 50 & 49 & 54 & - & - & \\
\hline 998 & Feb. & Low & 34 & 36 & 43 & 38 & 40 & 46 & 33 & 40 & 35 & 39 & 44 & 43 & 41 & 42 & 42 & 32 & 40 & 44 & 44 & 44 & 41 & 33 & 31 & 29 & 36 & 31 & 29 & 43 & - & - & \\
\hline 1998 & Mar. & High & 53 & 51 & 47 & 50 & 54 & 52 & 51 & 51 & 53 & 51 & 68 & 59 & 63 & 65 & 57 & 57 & 56 & 63 & 66 & 68 & 55 & 61 & 60 & 60 & 59 & 52 & 46 & 50 & 58 & 50 & $J_{2}$ \\
\hline 1998 & Mar. & Low & 47 & 39 & 36 & 32 & 28 & 27 & 26 & 41 & 38 & 33 & 47 & 48 & 49 & 44 & 48 & 36 & 31 & 35 & 33 & 39 & 43 & 51 & 44 & 47 & 40 & 39 & 34 & 31 & 30 & 36 & 40 \\
\hline 1998 & Apr. & High & 54 & 56 & 48 & 55 & 56 & 58 & 51 & 57 & 58 & 56 & 55 & 54 & 55 & 55 & 58 & 59 & 63 & 59 & 59 & 71 & 71 & 70 & 57 & 58 & 57 & 67 & 74 & 79 & 83 & 82 & \\
\hline 1998 & Apr. & Low & 40 & 43 & 43 & 41 & 36 & 41 & 34 & 33 & 42 & 41 & 37 & 39 & 35 & 37 & 38 & 32 & 33 & 45 & 36 & 0 & 38 & 48 & 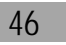 & 38 & 37 & 36 & 42 & 44 & 50 & 1 & \\
\hline 1998 & May. & High & 84 & 68 & 70 & 69 & 69 & 7 & 67 & 54 & 52 & 55 & 57 & 51 & 53 & 57 & 56 & 50 & 61 & 60 & 62 & 55 & bu & 60 & 65 & 60 & 58 & 60 & 65 & 76 & 60 & 5 & 10 \\
\hline 1998 & May. & Low & 52 & 51 & 52 & 54 & 52 & 52 & 50 & 45 & 43 & 48 & 47 & 46 & 47 & 45 & 42 & 45 & 42 & 42 & 49 & 48 & 44 & 44 & 52 & 45 & 42 & 38 & 40 & 42 & 52 & 51 & 47 \\
\hline 998 & Jun. & High & 74 & 68 & 74 & 64 & 72 & 80 & 76 & 73 & 77 & 65 & 70 & 75 & 71 & 73 & 67 & 68 & 75 & 62 & 71 & 80 & 83 & 71 & 73 & 68 & 64 & 68 & 75 & 83 & 82 & 67 & \\
\hline 1998 & Jun. & Low & 49 & 48 & 46 & 54 & 51 & 51 & 50 & 50 & 51 & 53 & 52 & 52 & 51 & 49 & 51 & 50 & 45 & 44 & 51 & 49 & 52 & 50 & 53 & 53 & 52 & 52 & 47 & 50 & 50 & 52 & \\
\hline 1998 & Jul. & High & 67 & 74 & 66 & 70 & 77 & 85 & 78 & 82 & 85 & 75 & 77 & 77 & 80 & 84 & 86 & 95 & 91 & 84 & 79 & 85 & 91 & 94 & 87 & 84 & 86 & 100 & 101 & 99 & 82 & 79 & 73 \\
\hline 1998 & Jul. & Low & 55 & 56 & 56 & 57 & 58 & 56 & 5 & 53 & s & 5 & 49 & 5 & 5 & 55 & 53 & 57 & 54 & 55 & 58 & 53 & 54 & 58 & 56 & 57 & 56 & 62 & 5 & 60 & 6 & 7 & ou \\
\hline 998 & Aug. & High & $7 \varepsilon$ & 90 & 93 & 9 & 86 & 81 & 80 & 86 & 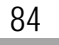 & 86 & 90 & 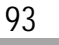 & 9 & 91 & 74 & 75 & 76 & 75 & 81 & 81 & 76 & 80 & 1 & 8 & 80 & 77 & 87 & 92 & 38 & 88 & 96 \\
\hline 1998 & Aug. & Low & 5 & 52 & 53 & 61 & 59 & 5 & 49 & 53 & 51 & 50 & 61 & 5 & 60 & 60 & 60 & 57 & 50 & 50 & 49 & 51 & 55 & 52 & 56 & 48 & 47 & 51 & 54 & 54 & 50 & 56 & 54 \\
\hline 1998 & Sep. & High & 96 & 92 & 93 & 89 & 86 & 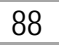 & 86 & 71 & 72 & 76 & 84 & 86 & 83 & 85 & 88 & 81 & 77 & 69 & 69 & 69 & 80 & 75 & 80 & 67 & 65 & 73 & 82 & 77 & 88 & 77 & \\
\hline 1998 & Sep. & Low & 58 & 56 & 58 & 56 & 50 & 44 & 53 & 53 & 44 & 43 & 50 & 52 & 49 & 56 & 52 & 48 & 49 & $5 /$ & 51 & 47 & 48 & 48 & 47 & 44 & 45 & 44 & 49 & 46 & 45 & 42 & \\
\hline 1998 & Oct. & High & 63 & 58 & 61 & 66 & 69 & 72 & 76 & 64 & 55 & 61 & 62 & 60 & 64 & 62 & 59 & 55 & 59 & 60 & 69 & 75 & 75 & 73 & 51 & 63 & 63 & 64 & 59 & 57 & 43 & 49 & 51 \\
\hline 1998 & Oct. & Low & 51 & 50 & 5 & 46 & 41 & 4 & 48 & 52 & 46 & 43 & 42 & 5 & 49 & 45 & 41 & 36 & 38 & 41 & 37 & 38 & 38 & 40 & 40 & 46 & 46 & 42 & 45 & 36 & 34 & 35 & 35 \\
\hline 1998 & Nov. & High & 57 & 59 & 54 & 59 & 55 & 52 & 46 & 50 & 5 & 49 & 48 & 5 & 56 & 58 & 61 & 48 & 57 & 55 & 51 & 6 & 56 & 49 & 55 & 51 & 64 & 2 & 52 & 44 & 18 & 47 & \\
\hline 1998 & Nov. & Low & 49 & 43 & 44 & 48 & 44 & 4 & 40 & 35 & 33 & 43 & 44 & 42 & 50 & 45 & 47 & 42 & 40 & 40 & 39 & 50 & 43 & 42 & 40 & 43 & 50 & 44 & 35 & 32 & 39 & 40 & - \\
\hline 1998 & Dec. & High & 50 & 51 & 45 & 45 & 41 & 42 & 45 & 45 & $4 c$ & 48 & 52 & 61 & 56 & 49 & 49 & 46 & 46 & $r$ & 35 & 25 & 22 & 30 & 26 & 43 & $2<$ & 47 & 52 & 2 & 5 & 8 & 33 \\
\hline 1998 & Dec. & Low & 44 & 38 & 21 & 33 & 35 & 3 & 40 & 32 & $2 \varepsilon$ & 38 & $4 \varepsilon$ & 5 & 17 & 32 & 3 & 28 & 3 & 28 & 23 & 14 & 12 & 15 & 1 & 26 & 42 & 39 & & 0 & 1 & 51 & \\
\hline 1999 & Jan. & High & 47 & 45 & 50 & 45 & 40 & 46 & 50 & 39 & 49 & 57 & 48 & 4 & 4 & 52 & 52 & 48 & 54 & 50 & 51 & 48 & 50 & 45 & 46 & 40 & 37 & 42 & 44 & 48 & 56 & 46 & 49 \\
\hline 1999 & Jan. & Low & 31 & 30 & 26 & 26 & 27 & 30 & 32 & 31 & 34 & 32 & 31 & 37 & 38 & 47 & 43 & 40 & 42 & 46 & 44 & 44 & 44 & 36 & 37 & 28 & 30 & 32 & 35 & 43 & 43 & 40 & 37 \\
\hline 1999 & Feb. & High & 49 & 50 & 49 & 48 & 46 & 50 & 46 & 41 & 45 & 43 & 47 & 54 & 50 & 50 & 54 & 48 & 50 & 49 & 52 & 52 & $4 \pi$ & 50 & 53 & 53 & 46 & 9 & 55 & 56 & - & - & \\
\hline 99 & Feb. & Low & 37 & 35 & 34 & 3 & 32 & 4 & $x$ & 34 & $u$ & 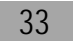 & 33 & 33 & 39 & 31 & 3 & 43 & & 40 & 31 & & 40 & & & & 37 & 5 & 44 & 40 & - & 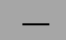 & \\
\hline 1999 & Mar. & High & 49 & 48 & 46 & 46 & 45 & 50 & 50 & 51 & 48 & 54 & 57 & 50 & 58 & 50 & 52 & 52 & 54 & 57 & 69 & 59 & 61 & 61 & 62 & 53 & 52 & 49 & 50 & 47 & 48 & 46 & 50 \\
\hline 999 & Mar. & Low & 35 & 34 & 36 & 34 & 33 & 27 & 31 & 38 & 33 & 33 & 27 & 43 & 44 & 42 & 36 & 31 & 38 & 45 & 36 & 45 & 44 & 42 & 36 & 43 & 42 & 38 & 34 & 36 & 38 & 36 & 34 \\
\hline
\end{tabular}


Appendix C1. Average Temperature Data for Willamette Valley by Month 1980-Present

\begin{tabular}{|c|c|c|c|c|c|c|c|c|c|c|c|c|c|c|c|c|c|c|c|c|c|c|c|c|c|c|c|c|c|c|c|c|c|}
\hline & & & & & & & & & & & & 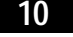 & & 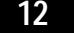 & U & 14 & $\mathbf{N}$ & 10 & \pm & 10 & $\boldsymbol{L}$ & 20 & $\Sigma$ & 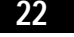 & $\omega$ & 44 & 20 & 40 & 21 & 20 & $\Delta$ & 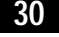 & \\
\hline & Apr. & High & 56 & 56 & 50 & 48 & 56 & 59 & 54 & 51 & 49 & 55 & 68 & 55 & 58 & 70 & 81 & 80 & 71 & 61 & 57 & 57 & 52 & 62 & 75 & 79 & 57 & 54 & 50 & 58 & 69 & 68 & \\
\hline 1999 & Apr. & Low & 29 & 32 & 35 & 37 & 37 & 31 & 37 & 35 & 34 & 41 & 36 & 44 & 42 & 35 & 38 & 41 & 50 & 46 & 42 & 41 & 41 & 40 & 40 & 41 & 44 & 34 & 37 & 33 & 35 & 36 & \\
\hline 1999 & May. & High & 55 & 52 & 55 & 55 & 65 & 63 & 51 & 53 & 56 & 59 & 62 & 57 & 54 & 57 & 60 & 64 & 65 & 61 & 63 & 61 & 67 & 79 & 89 & 76 & 68 & 76 & 77 & 69 & 72 & 76 & 71 \\
\hline 999 & May. & Low & 45 & 44 & 42 & 38 & 37 & 40 & 36 & 34 & 35 & 40 & 48 & 43 & 41 & 43 & 43 & 42 & 48 & 46 & 42 & 43 & 43 & 44 & 49 & 50 & 46 & 40 & 45 & 46 & 40 & 38 & 48 \\
\hline 99 & Jun. & High & 59 & 65 & 69 & 65 & 64 & 59 & 55 & 61 & 67 & 75 & 83 & 83 & 85 & 85 & 69 & 77 & 76 & 72 & 72 & 68 & 68 & 73 & 82 & 66 & 65 & 63 & 68 & 71 & 82 & 76 & \\
\hline 99 & Jun. & Low & 46 & 41 & 40 & 47 & 45 & 42 & 12 & 45 & 40 & 41 & 47 & 56 & 56 & 55 & 55 & 53 & 50 & 51 & 54 & 49 & 54 & 55 & 50 & 48 & 50 & 49 & 49 & 47 & 55 & 57 & \\
\hline 999 & Jul. & High & 69 & 62 & 66 & 70 & 85 & 68 & 70 & 83 & 91 & 90 & 91 & 89 & 85 & 72 & 80 & 70 & 74 & 83 & 92 & 84 & 75 & 87 & 88 & 74 & 78 & 88 & 90 & 89 & 82 & 83 & 34 \\
\hline 99 & Jul. & Low & 52 & 51 & 45 & 51 & 47 & 54 & 51 & 48 & 49 & 52 & 51 & 55 & 52 & 49 & 48 & 49 & 53 & 50 & 54 & 53 & 58 & 54 & 56 & 54 & 56 & 49 & 52 & 56 & 51 & 51 & 3 \\
\hline 999 & Aug. & High & 78 & 89 & 88 & 86 & 77 & 70 & do & 78 & 88 & 89 & 67 & 79 & 74 & 70 & 78 & 88 & 90 & 78 & 80 & 83 & 81 & 89 & 87 & 89 & 85 & 89 & 88 & 84 & 65 & 67 & \\
\hline 99 & Aug. & Low & 52 & 51 & 56 & 56 & 61 & 60 & 58 & 58 & 54 & 57 & 56 & 53 & 56 & 55 & 50 & 53 & 57 & 56 & 59 & 53 & 56 & 53 & 54 & 57 & 57 & 57 & 59 & 61 & 57 & 51 & \\
\hline 999 & Sep. & High & 77 & 81 & 84 & 84 & 78 & 74 & 81 & 89 & 77 & 76 & 87 & 95 & 94 & 88 & 75 & 71 & 75 & 92 & 92 & 91 & 89 & 88 & 73 & 71 & 69 & 65 & 66 & 78 & 80 & 68 & \\
\hline 999 & Sep. & Low & 42 & 46 & 46 & 49 & 50 & 53 & 46 & 47 & 46 & 42 & 47 & 48 & 48 & 47 & 48 & 47 & 52 & 49 & 49 & 53 & 49 & 51 & 49 & 39 & 44 & 40 & 35 & 37 & 41 & 45 & \\
\hline 999 & Oct. & High & 76 & 77 & 77 & 65 & 65 & 68 & 70 & 61 & 63 & 68 & 70 & 74 & 73 & 63 & 59 & 69 & 71 & 77 & 77 & 73 & 71 & 71 & 60 & 64 & 58 & 54 & 57 & 59 & 61 & 63 & गठ \\
\hline 99 & Oct. & Low & 38 & 40 & 40 & 38 & 53 & 51 & 53 & 50 & 43 & 39 & 43 & 42 & 46 & 38 & 31 & 32 & 39 & 39 & 43 & 37 & 37 & 37 & 37 & 44 & 42 & 34 & 38 & 45 & 44 & 0 & \\
\hline 999 & Nov. & High & 63 & 58 & 57 & 54 & 52 & 64 & 54 & 57 & 57 & 58 & 65 & 65 & 70 & 54 & 62 & 54 & 56 & 45 & 53 & 54 & 50 & 48 & 48 & 53 & 57 & 56 & 52 & 49 & 52 & 55 & \\
\hline 999 & Nov. & Low & 35 & 34 & 36 & 34 & 37 & 47 & 45 & 48 & 47 & 50 & 50 & 60 & 49 & 46 & 51 & 47 & 37 & 35 & 41 & 43 & 41 & 42 & 43 & 46 & 53 & 41 & 39 & 33 & 37 & 42 & \\
\hline 999 & Dec. & High & 49 & 50 & 50 & 45 & 50 & 50 & 46 & 47 & 47 & 46 & 53 & 51 & 43 & 47 & 53 & 54 & 56 & 53 & 50 & 48 & 53 & 56 & 50 & 48 & 50 & 51 & 50 & 45 & 42 & 42 & 43 \\
\hline 99 & Dec. & Low & 42 & 38 & 33 & 34 & 43 & 42 & 39 & 40 & 41 & 41 & 45 & 31 & 36 & 41 & 46 & 50 & 48 & 44 & 37 & 34 & 35 & 28 & 28 & 25 & 27 & 32 & 27 & 24 & 23 & 1 & \\
\hline 000 & Jan. & High & 47 & 43 & 48 & 51 & 48 & 45 & 52 & 51 & 48 & 42 & 42 & 41 & 44 & 50 & 39 & 48 & 47 & 41 & 42 & 48 & 54 & 51 & 43 & 40 & 49 & 48 & 43 & 51 & 48 & 3 & \\
\hline 000 & Jan. & Low & 39 & 38 & 40 & 41 & 29 & 28 & 44 & 43 & 40 & 36 & 33 & 33 & 38 & 31 & 28 & 37 & 29 & 27 & 26 & 37 & 42 & 32 & 29 & 34 & 35 & 35 & 30 & 24 & 25 & 31 & 35 \\
\hline 000 & Feb. & High & 55 & 49 & 61 & 54 & 50 & 51 & 51 & 53 & 50 & 51 & 46 & 47 & 43 & 48 & 52 & 57 & 50 & 44 & 50 & 51 & 53 & 50 & 51 & 51 & 46 & 51 & 55 & 49 & 52 & - & \\
\hline 000 & Feb. & Low & 46 & 40 & 33 & 39 & 39 & 41 & 38 & 35 & 30 & 28 & 41 & 33 & 34 & 40 & 35 & 33 & 27 & 31 & 33 & 30 & 41 & 41 & 31 & 30 & 36 & 11 & 39 & 42 & 34 & - & \\
\hline 2000 & Mar. & High & 49 & 56 & 50 & 46 & 46 & 51 & 49 & 52 & 56 & 53 & 54 & 59 & 57 & 55 & 51 & 53 & 50 & 50 & 49 & 53 & 63 & 53 & 53 & 58 & 54 & 62 & 52 & 49 & 54 & 64 & 69 \\
\hline 000 & Mar. & Low & 32 & 38 & 35 & 34 & 29 & 32 & 30 & 34 & 33 & 35 & 35 & 32 & 38 & 34 & 30 & 38 & 37 & 40 & 35 & 37 & 39 & 39 & 36 & 31 & 35 & 32 & 39 & 37 & 31 & 31 & 34 \\
\hline 000 & Apr. & High & 74 & 68 & 76 & 55 & 55 & 56 & 68 & 65 & 56 & 67 & 72 & 74 & 57 & 59 & 57 & 58 & 69 & 62 & 60 & 69 & 66 & 55 & 53 & 53 & 58 & 68 & 61 & 55 & 62 & 69 & \\
\hline 000 & Apr. & Low & 40 & 40 & 41 & 38 & 33 & $3 c$ & 34 & 40 & $4 c$ & 35 & 38 & 51 & 48 & 48 & 47 & 47 & 45 & 40 & 42 & 42 & 40 & 38 & 32 & 30 & 38 & 38 & 41 & 37 & 34 & 44 & \\
\hline 2000 & May. & High & 66 & 64 & 59 & 58 & 57 & 62 & 64 & 63 & 5 & 49 & 55 & 62 & 66 & 75 & 69 & 68 & 64 & 73 & 71 & 7 & 88 & 74 & 68 & 72 & 65 & 69 & 67 & 64 & 63 & 60 & 52 \\
\hline 000 & May. & Low & 46 & 49 & 47 & 45 & 39 & 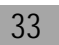 & 39 & 50 & $43^{2}$ & 41 & 42 & 38 & 50 & 48 & 51 & 48 & 41 & 45 & 50 & 48 & 47 & 53 & 51 & 48 & 46 & 51 & 50 & 52 & 49 & 46 & $4 \pi$ \\
\hline 000 & Jun. & Higl & 78 & 77 & 84 & 82 & 70 & 65 & 66 & 64 & 65 & 59 & 58 & 6 & 78 & 83 & 73 & 83 & 88 & 73 & 72 & 81 & 81 & 75 & 75 & 78 & 87 & 92 & 99 & 94 & 88 & 76 & \\
\hline 2000 & Jun. & Low & 42 & 47 & 45 & 50 & 50 & 53 & 55 & 51 & 44 & 45 & 49 & 53 & 51 & 52 & 50 & 46 & 54 & 52 & 52 & 48 & 53 & 49 & 46 & 48 & 50 & 55 & 52 & 60 & 51 & 50 & \\
\hline 2000 & Jul. & High & 71 & 68 & 66 & 67 & 76 & 76 & 83 & 72 & 75 & 78 & 75 & 82 & 75 & 76 & 85 & 92 & 81 & 75 & 82 & 87 & 87 & 73 & 81 & 87 & 78 & 78 & 86 & 84 & 89 & 94 & 39 \\
\hline 2000 & Jul. & Lon & 52 & 46 & 47 & 49 & 53 & 5 & 49 & 51 & 5 & 54 & 53 & 46 & 48 & 56 & 48 & 51 & 55 & 56 & 47 & 53 & 58 & 56 & $4 y$ & 51 & 50 & 6 & 52 & bb & 55 & 59 & 57 \\
\hline .000 & Aug. & & 84 & 85 & 86 & 89 & on & 88 & 85 & On & 84 & 72 & 75 & 78 & 77 & 76 & 75 & 80 & 78 & 60 & 73 & 77 & 83 & on & & 75 & 70 & & 74 & Q2 & 82 & $\pi$ & \\
\hline 2000 & ug. & Low & 60 & 50 & 53 & 53 & 53 & 54 & 56 & 53 & 55 & 57 & 55 & 47 & 46 & 52 & 46 & 46 & 45 & 49 & 48 & 45 & 48 & 55 & 53 & 52 & 51 & 50 & 45 & 46 & 49 & 59 & 50 \\
\hline 2000 & Sep. & High & 70 & 64 & 67 & 70 & 72 & 74 & 76 & 65 & 71 & 68 & 80 & 85 & 89 & 84 & 74 & 75 & 78 & 83 & 78 & 80 & 73 & 68 & 74 & 78 & 77 & 81 & 79 & 71 & 77 & 73 & \\
\hline 2000 & Sep. & Low & 49 & 51 & 46 & 43 & 47 & 50 & 45 & 48 & 44 & 55 & 58 & 5 & 53 & 58 & 55 & 53 & 49 & 57 & 60 & 52 & 56 & 37 & 32 & 35 & 40 & 40 & 44 & 46 & 57 & 62 & \\
\hline 2000 & Oct. & High & 0 & 64 & 66 & 65 & 78 & 80 & 77 & 73 & 59 & 54 & 60 & 57 & 60 & 62 & bI & 70 & 71 & 00 & 3 & 01 & 58 & $\partial$ & 6 & 65 & DI & & & 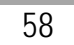 & 11 & 58 & 59 \\
\hline 2000 & Oct. & Low & 52 & 40 & 38 & 42 & 41 & $4 C$ & 40 & 4 & 4 & 48 & 49 & 5 & 5 & 36 & & 51 & 45 & 46 & 42 & & 37 & $n$ & 32 & 34 & 46 & 5 & 50 & 44 & 10 & 35 & \\
\hline 2000 & Nov. & High & 50 & 56 & 58 & 58 & 53 & 56 & 48 & 53 & 49 & 49 & 45 & 47 & 48 & 48 & 51 & 47 & 49 & 44 & 40 & 50 & 50 & 46 & 51 & 51 & 49 & 52 & 3 & 48 & 53 & 55 & \\
\hline 2000 & Nov. & Lo & 44 & 48 & 46 & 39 & 43 & $3^{5}$ & 35 & 42 & 36 & 29 & 25 & 23 & 32 & 26 & 29 & 23 & 28 & 20 & 21 & 30 & 26 & 22 & 27 & 35 & 39 & 12 & 29 & 28 & 38 & 35 & \\
\hline 000 & Dec. & High & 49 & 50 & 46 & 49 & 51 & 46 & 41 & 41 & 49 & 47 & 38 & 31 & 40 & 50 & 48 & 57 & 49 & 45 & 44 & 15 & 51 & 51 & 49 & 51 & 6 & 47 & 51 & 8 & 43 & 47 & Do \\
\hline 000 & Dec. & Low & 31 & 43 & 33 & 31 & 28 & 26 & 25 & 25 & 34 & 34 & 31 & 31 & 32 & 34 & 41 & 40 & 21 & 21 & 36 & 40 & 32 & 45 & 42 & 34 & 32 & 36 & 31 & 32 & 28 & 41 & $4 \angle$ \\
\hline
\end{tabular}


Appendix C1. Average Temperature Data for Willamette Valley by Month 1980-Present

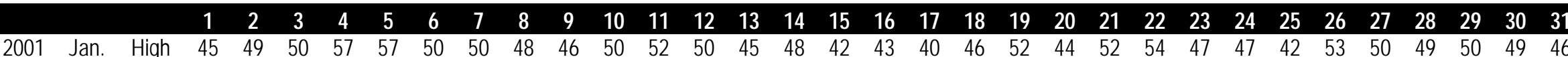

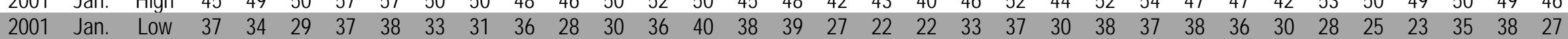

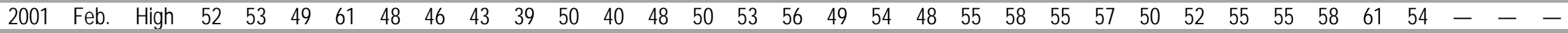

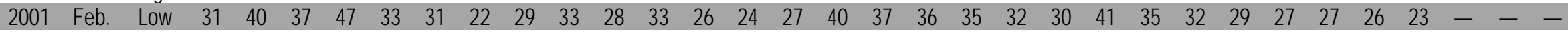

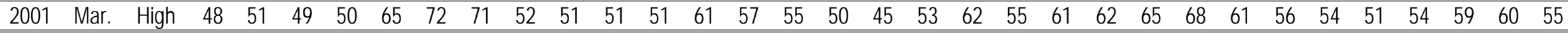

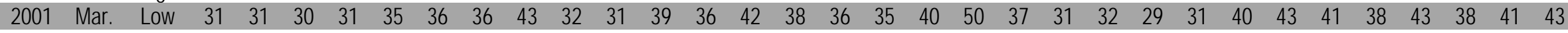

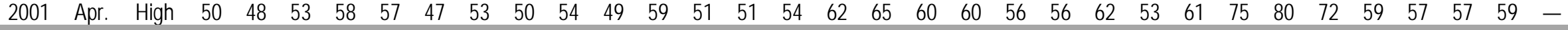
2001 Apr. Low $40 \begin{array}{lllllllllllllllllllllllllllllll}34 & 34 & 28 & 30 & 33 & 31 & 35 & 31 & 42 & 39 & 38 & 31 & 31 & 31 & 40 & 41 & 46 & 44 & 43 & 36 & 37 & 47 & 43 & 46 & 44 & 41 & 41 & 44 & 42 & -\end{array}$

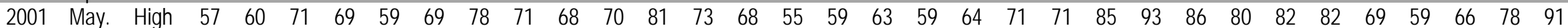
2001 May. Low $40 \begin{array}{llllllllllllllllllllllllllllllllllll}36 & 37 & 44 & 37 & 37 & 38 & 46 & 38 & 37 & 44 & 48 & 50 & 49 & 48 & 46 & 42 & 43 & 41 & 43 & 45 & 53 & 50 & 49 & 46 & 47 & 44 & 38 & 35 & 44 & 50\end{array}$

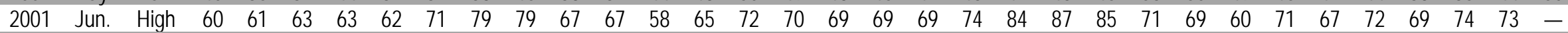

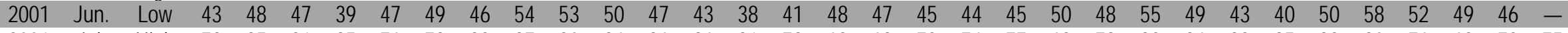

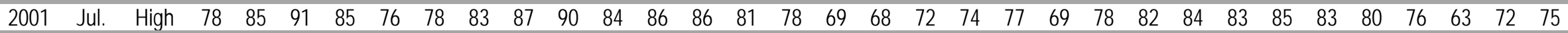

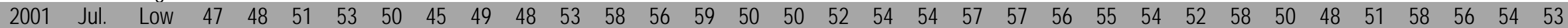

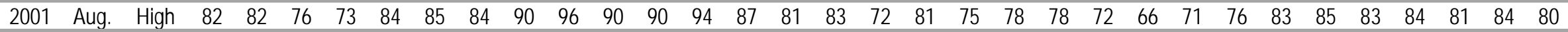

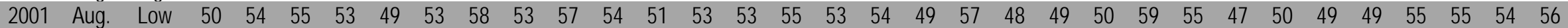

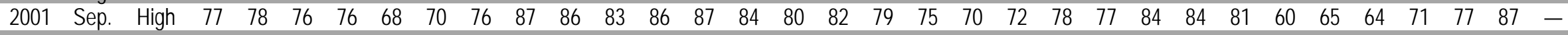

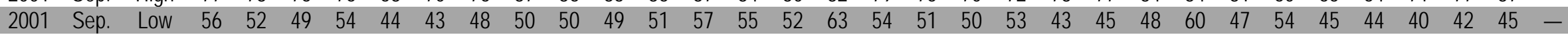

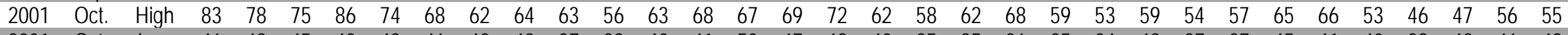

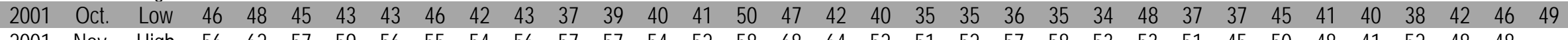

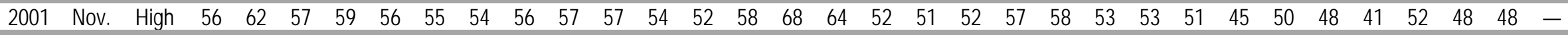
2001 Nov. Low $50 \begin{array}{llllllllllllllllllllllllllllllllllllllll}4 & 50 & 51 & 40 & 38 & 30 & 28 & 29 & 35 & 35 & 34 & 49 & 58 & 51 & 39 & 38 & 33 & 44 & 49 & 46 & 43 & 40 & 41 & 41 & 40 & 33 & 36 & 40 & 43 & -\end{array}$ 2001 Dec. $\begin{array}{llllllllllllllllllllllllllllllllllllll} & 50 & 47 & 48 & 42 & 49 & 54 & 49 & 50 & 48 & 49 & 47 & 49 & 52 & 45 & 49 & 56 & 46 & 46 & 45 & 46 & 45 & 47 & 48 & 46 & 46 & 42 & 42 & 46 & 40 & 46 & 45\end{array}$ 2001 Dec. $\quad$ Low $44 \begin{array}{lllllllllllllllllllllllllllllll}38 & 39 & 37 & 32 & 42 & 38 & 38 & 34 & 36 & 36 & 41 & 44 & 34 & 38 & 45 & 34 & 40 & 32 & 41 & 32 & 29 & 27 & 22 & 26 & 29 & 37 & 31 & 30 & 29 & 37\end{array}$ 2002 Jan. $\begin{array}{lllllllllllllllllllllllllllllllllllllllll} & 44 & 56 & 54 & 43 & 52 & 60 & 60 & 54 & 47 & 49 & 47 & 51 & 42 & 43 & 44 & 38 & 42 & 45 & 47 & 47 & 41 & 41 & 44 & 47 & 47 & 41 & 36 & 40 & 39 & 42 & 43\end{array}$

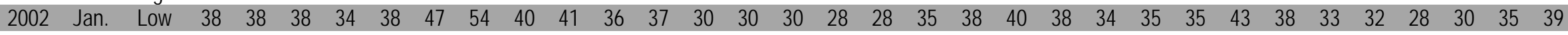
$\begin{array}{llllllllllllllllllllllllllllllllllllllllll}2002 & \text { Feb. } & \text { High } & 46 & 47 & 51 & 45 & 50 & 51 & 45 & 51 & 50 & 56 & 47 & 52 & 51 & 57 & 62 & 52 & 50 & 56 & 53 & 59 & 64 & 65 & 55 & 48 & 54 & 53 & 55 & 52 & - & - & -\end{array}$

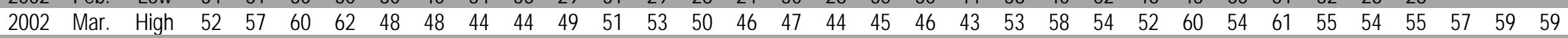

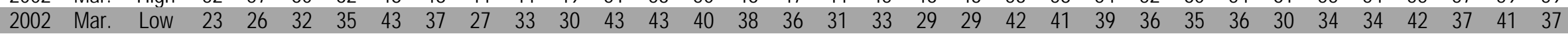

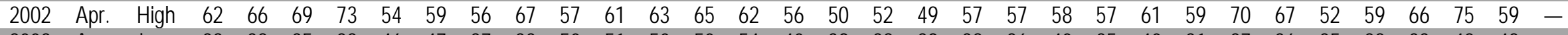

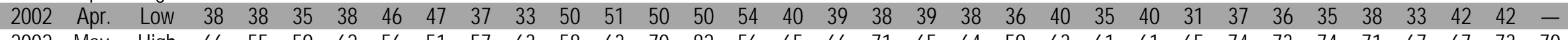

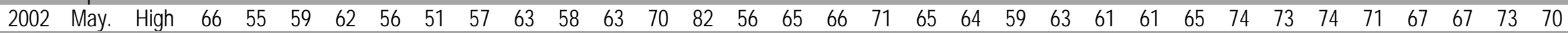
2002 May. Low $48 \begin{array}{lllllllllllllllllllllllllllllll} & 39 & 39 & 33 & 40 & 38 & 36 & 31 & 42 & 36 & 35 & 41 & 43 & 41 & 37 & 38 & 47 & 48 & 48 & 44 & 43 & 45 & 37 & 42 & 52 & 54 & 57 & 57 & 55 & 51 & 44\end{array}$

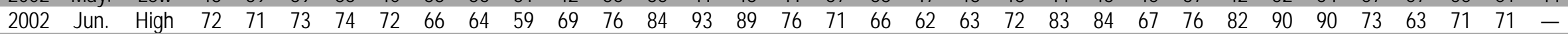
2002 Jun. Low $48 \begin{array}{lllllllllllllllllllllllllllllll} & 42 & 46 & 56 & 51 & 45 & 42 & 44 & 43 & 43 & 48 & 53 & 56 & 50 & 47 & 52 & 52 & 52 & 43 & 49 & 51 & 53 & 48 & 53 & 54 & 58 & 56 & 55 & 54 & 53 & -\end{array}$ $\begin{array}{lllllllllllllllllllllllllllllllllllllllllll}2002 & \text { Jul. } & \text { High } & 74 & 79 & 72 & 71 & 81 & 84 & 75 & 78 & 94 & 97 & 92 & 92 & 87 & 79 & 85 & 86 & 84 & 80 & 77 & 86 & 92 & 94 & 86 & 85 & 84 & 80 & 79 & 87 & 87 & 80 & 79\end{array}$

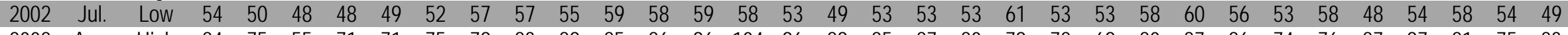
\begin{tabular}{llllllllllllllllllllllllllllllllllllllllll}
2002 & Aug. & High & 84 & 75 & 55 & 71 & 71 & 75 & 79 & 83 & 89 & 85 & 86 & 96 & 104 & 96 & 89 & 85 & 87 & 80 & 79 & 72 & 69 & 80 & 87 & 86 & 74 & 76 & 87 & 97 & 81 & 75 & 83 \\
\hline
\end{tabular}

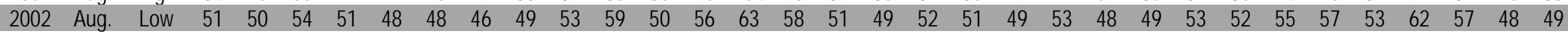

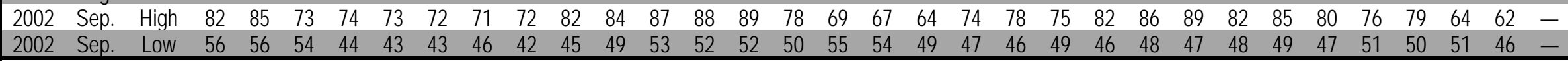


Appendix C1. Average Temperature Data for Willamette Valley by Month 1980-Present

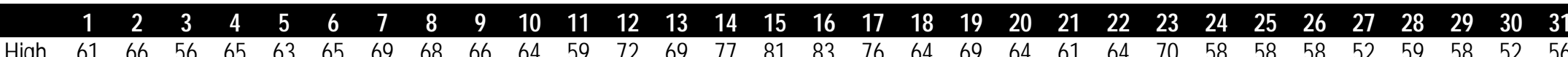

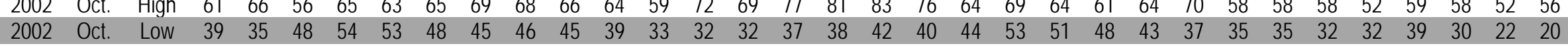

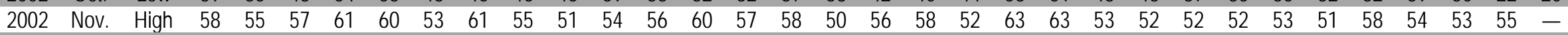

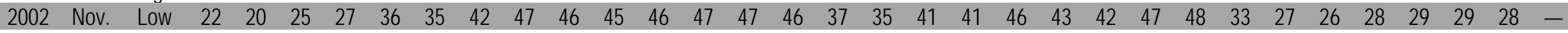

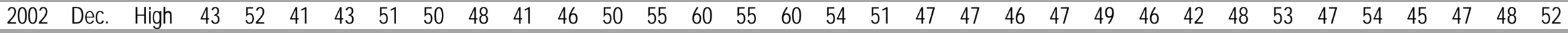
2002 Dec. Low $29 \begin{array}{lllllllllllllllllllllllllllllllll}31 & 33 & 37 & 32 & 31 & 27 & 26 & 30 & 43 & 45 & 47 & 43 & 47 & 45 & 39 & 38 & 37 & 36 & 33 & 39 & 39 & 31 & 34 & 40 & 40 & 42 & 41 & 34 & 44 & 43\end{array}$

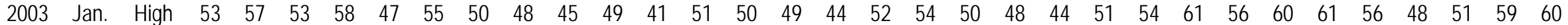
2003 Jan. Low $43 \begin{array}{lllllllllllllllllllllllllllllll}49 & 47 & 37 & 31 & 28 & 28 & 24 & 26 & 36 & 35 & 41 & 40 & 31 & 32 & 29 & 36 & 32 & 26 & 32 & 36 & 42 & 39 & 48 & 52 & 45 & 42 & 41 & 45 & 50 & 47\end{array}$

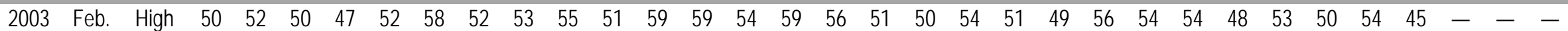

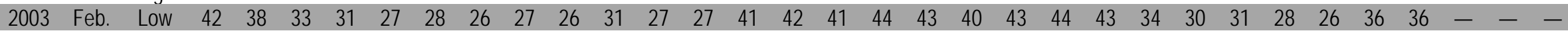

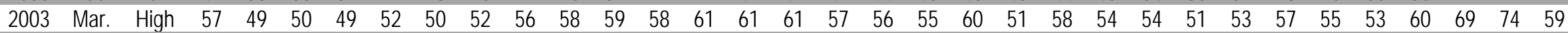
2003 Mar. Low $36 \begin{array}{llllllllllllllllllllllllllllllll}31 & 36 & 37 & 45 & 45 & 46 & 45 & 47 & 46 & 48 & 51 & 50 & 48 & 45 & 37 & 33 & 38 & 40 & 46 & 45 & 43 & 37 & 29 & 45 & 38 & 39 & 38 & 40 & 42 & 43\end{array}$

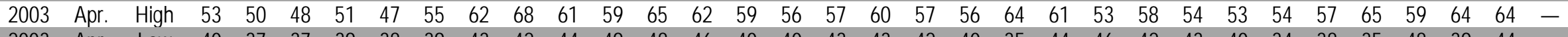
2003 Apr. Low $40 \begin{array}{lllllllllllllllllllllllllllllllllll} & 37 & 37 & 39 & 38 & 39 & 43 & 42 & 44 & 49 & 48 & 46 & 40 & 40 & 43 & 43 & 42 & 40 & 35 & 44 & 46 & 42 & 43 & 40 & 34 & 38 & 35 & 48 & 39 & 44 & -\end{array}$ 2003 May. High $64 \begin{array}{lllllllllllllllllllllllllllllllllll} & 72 & 56 & 57 & 58 & 59 & 55 & 56 & 61 & 61 & 66 & 65 & 75 & 63 & 57 & 54 & 56 & 60 & 73 & 68 & 76 & 77 & 85 & 71 & 63 & 68 & 84 & 78 & 82 & 62 & 73\end{array}$ 2003 May. Low $39 \begin{array}{lllllllllllllllllllllllllllllllllll} & 31 & 41 & 46 & 41 & 39 & 41 & 43 & 47 & 47 & 44 & 50 & 43 & 44 & 41 & 41 & 37 & 34 & 37 & 45 & 47 & 51 & 52 & 54 & 52 & 50 & 45 & 56 & 52 & 51 & 47\end{array}$ 2003 Jun. $\begin{array}{lllllllllllllllllllllllllllllllll} & 75 & 74 & 81 & 90 & 96 & 96 & 89 & 78 & 68 & 70 & 74 & 66 & 65 & 72 & 77 & 84 & 84 & 70 & 66 & 65 & 66 & 66 & 63 & 75 & 84 & 91 & 90 & 97 & 86 & 75 & -\end{array}$

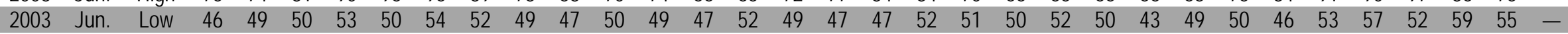

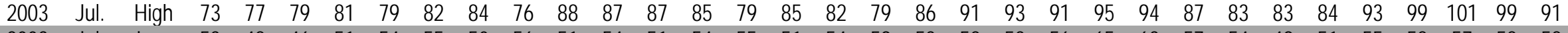

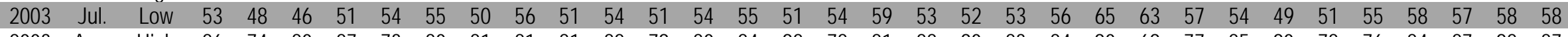
2003 Aug. $\begin{array}{lllllllllllllllllllllllllllllllllll} & 86 & 74 & 80 & 87 & 73 & 80 & 81 & 81 & 81 & 82 & 79 & 80 & 84 & 92 & 78 & 81 & 88 & 90 & 83 & 84 & 90 & 69 & 77 & 85 & 90 & 78 & 76 & 84 & 87 & 92 & 87\end{array}$ 2003 Aug. Low $57 \begin{array}{lllllllllllllllllllllllllllllllllll} & 63 & 58 & 54 & 55 & 49 & 59 & 59 & 60 & 57 & 54 & 56 & 51 & 58 & 58 & 54 & 58 & 58 & 56 & 51 & 52 & 55 & 52 & 48 & 52 & 55 & 57 & 50 & 51 & 54 & 53\end{array}$

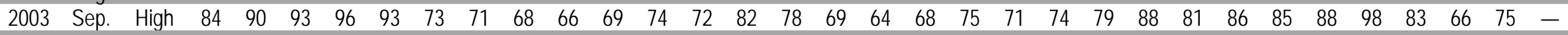
2003 Sep. L Low $44 \begin{array}{llllllllllllllllllllllllllllllll}52 & 57 & 56 & 55 & 56 & 54 & 51 & 53 & 58 & 58 & 50 & 48 & 46 & 43 & 47 & 46 & 43 & 55 & 45 & 49 & 50 & 49 & 49 & 50 & 59 & 54 & 50 & 52 & 48 & -\end{array}$

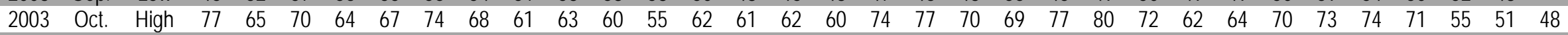

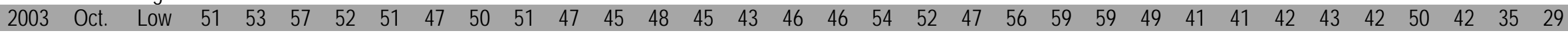
2003 Nov. $\begin{array}{lllllllllllllllllllllllllllllllllllllll} & 45 & 39 & 48 & 47 & 49 & 56 & 53 & 54 & 54 & 55 & 61 & 56 & 55 & 56 & 52 & 53 & 53 & 59 & 58 & 45 & 41 & 39 & 45 & 49 & 49 & 50 & 45 & 59 & 53 & 49 & - \\ 2003 & \text { Nov. } & \text { L } & 22 & 32 & 27 & 35 & 29 & 32 & 41 & 38 & 35 & 41 & 36 & 33 & 31 & 47 & 44 & 47 & 46 & 52 & 35 & 34 & 26 & 24 & 34 & 36 & 40 & 35 & 31 & 40 & 49 & 43 & -\end{array}$

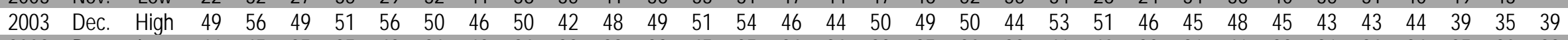
2003 Dec. L Low $44 \begin{array}{llllllllllllllllllllllllllllllllllllllll}45 & 35 & 35 & 48 & 36 & 42 & 36 & 39 & 39 & 38 & 45 & 35 & 36 & 36 & 38 & 35 & 30 & 32 & 41 & 40 & 32 & 31 & 41 & 32 & 31 & 36 & 34 & 25 & 20 & 33\end{array}$ 2004 Jan. High $37 \begin{array}{llllllllllllllllllllllllllllllllll} & 37 & 38 & 37 & 24 & 29 & 32 & 35 & 39 & 42 & 45 & 40 & 51 & 46 & 53 & 45 & 47 & 53 & 52 & 49 & 42 & 50 & 51 & 50 & 45 & 47 & 50 & 51 & 55 & 51 & 45\end{array}$

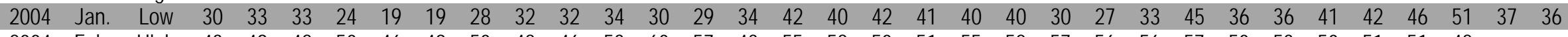

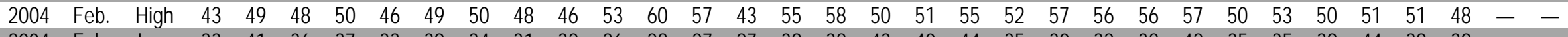

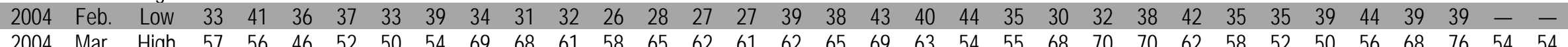

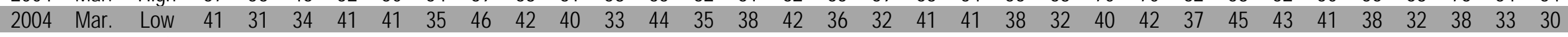

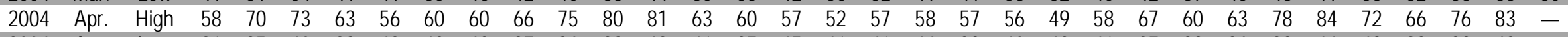

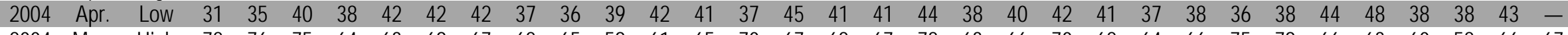

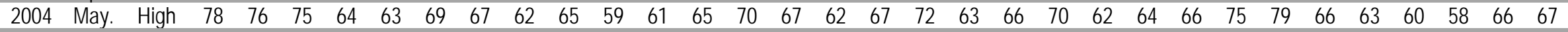
2004 May. Low $46 \begin{array}{llllllllllllllllllllllllllllllllllll}47 & 47 & 50 & 45 & 37 & 51 & 42 & 43 & 43 & 47 & 43 & 39 & 52 & 49 & 47 & 42 & 53 & 48 & 44 & 51 & 50 & 48 & 43 & 45 & 55 & 52 & 49 & 47 & 49 & 47\end{array}$

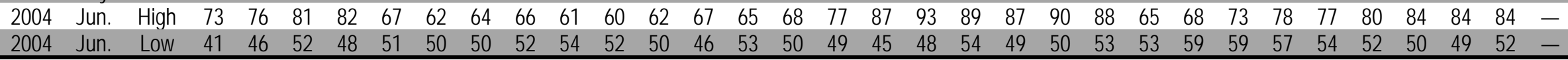




\begin{tabular}{|c|c|c|c|c|c|c|c|c|c|c|c|c|c|c|c|c|c|c|c|c|c|c|c|c|c|c|c|c|c|c|c|c|c|}
\hline & & & 1 & 2 & 3 & 4 & & 6 & 1 & 8 & $\mathbf{9}$ & 10 & 11 & 12 & $\mathbf{S}$ & 14 & 15 & 16 & 17 & 18 & 19 & 20 & 21 & 22 & 23 & 24 & 25 & 26 & 27 & 28 & 29 & 30 & 31 \\
\hline 2004 & Jul. & High & 81 & 79 & 78 & 78 & 84 & 83 & 74 & 74 & 74 & 73 & 82 & 92 & 85 & 87 & 84 & 87 & 85 & 89 & 80 & 82 & 88 & 99 & 104 & 99 & 87 & 85 & 90 & 91 & 90 & 83 & 86 \\
\hline 04 & the & W & 51 & & 56 & 51 & & 52 & 53 & $\Delta 6$ & ? & & 48 & & 57 & 56 & & 55 & 58 & & 60 & 62 & & 59 & 60 & ? & 58 & & 54 & 56 & 56 & 57 & -n \\
\hline 04 & & & & & 82 & & 7 & 74 & & 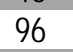 & & & 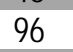 & & & On & & & 39 & & & 1 & 25 & 72 & & & 70 & 74 & 77 & 79 & 84 & 90 & 91 \\
\hline 04 & ig. & ow & 54 & 52 & 52 & 60 & 35 & 56 & 51 & 53 & 56 & 54 & 8 & 58 & 55 & 60 & 55 & 55 & 35 & 58 & 58 & 55 & 57 & 56 & 55 & 61 & 59 & 59 & 56 & 53 & 57 & 57 & 56 \\
\hline 2004 & Sep. & High & 74 & 67 & 73 & 13 & 76 & 80 & 80 & 78 & 71 & 80 & 71 & 68 & 71 & 72 & 70 & 69 & 64 & 56 & 62 & 67 & 69 & 71 & 75 & 75 & 68 & 72 & 31 & 79 & 65 & 88 & - \\
\hline 2004 & Sep. & Low & 51 & 51 & 51 & 54 & 49 & 47 & 50 & 49 & 52 & 48 & 57 & 56 & 55 & 49 & 54 & 49 & 50 & 48 & 46 & 42 & 41 & 43 & 47 & 48 & 47 & 56 & 01 & 49 & 22 & 49 & - \\
\hline 2004 & Oct. & High & $\pi$ & & 10 & 77 & 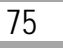 & 12 & 7. & I & 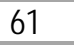 & & 00 & $T \perp$ & & 11 & & 03 & 50 & $\sqrt{7}$ & & 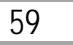 & & 05 & 34 & & $\pi$ & 56 & & r & & 57 & 54 \\
\hline 2004 & ct. & w & 41 & 13 & 44 & 42 & 46 & 58 & $5 ?$ & 51 & 45 & 42 & 41 & 45 & 48 & 48 & 48 & 48 & 49 & 47 & 49 & 48 & 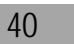 & 46 & 40 & 40 & 36 & 41 & 39 & 41 & 44 & 13 & 37 \\
\hline 2004 & ov. & High & 56 & 59 & 50 & 56 & 55 & 49 & 52 & 46 & 50 & 53 & 53 & 49 & 49 & 54 & 54 & 56 & 50 & 54 & 50 & 44 & 44 & 48 & 52 & 59 & 56 & 46 & 1 & 38 & 39 & 18 & - \\
\hline 04 & JV. & Low & 42 & 43 & 37 & 32 & 27 & 30 & 34 & 34 & 44 & 38 & 37 & 44 & 46 & 41 & 44 & 41 & 41 & 40 & 33 & 28 & 26 & 35 & 41 & 52 & 36 & 35 & 31 & 26 & 32 & 38 & - \\
\hline 02 & Jec. & High & 49 & 31 & 40 & 46 & 47 & 47 & 49 & 51 & 58 & $5 s$ & 56 & 54 & 51 & 56 & $\ldots$ & 40 & 48 & 52 & DU & 48 & 43 & 48 & 43 & 31 & 49 & 40 & 54 & 47 & $4 I$ & +ठ & 47 \\
\hline 02 & Dec. & ow & 3 & 3 & 35 & 3 & 36 & 39 & 40 & 46 & 48 & 54 & 44 & 42 & 37 & 40 & 34 & 38 & 38 & 3 & 32 & 29 & 2 & 41 & 30 & 3 & 34 & 35 & 35 & 30 & & 32 & 31 \\
\hline 2005 & n. & gh & 44 & 46 & 44 & 44 & 39 & 45 & 43 & 43 & 43 & 44 & 40 & 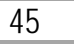 & 44 & 40 & 32 & 40 & 59 & 6 & 63 & 60 & 56 & 55 & 52 & 48 & 47 & 51 & 4 & 2 & 50 & 34 & 57 \\
\hline 2005 & an. & w & 31 & 30 & 29 & 28 & 20 & 32 & 37 & 36 & 35 & 30 & 23 & 37 & 35 & 27 & 29 & 31 & 38 & 57 & 46 & 42 & 41 & 39 & 36 & 35 & 39 & 40 & 43 & 41 & 41 & 34 & 33 \\
\hline 05 & eb. & High & 48 & 42 & 43 & 50 & 47 & 45 & 47 & 38 & 44 & 53 & 49 & 49 & $4 \mathrm{~s}$ & 47 & 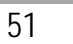 & 56 & 57 & 57 & 56 & 55 & 59 & 64 & 66 & 63 & 48 & 52 & 63 & 4 & - & - & - \\
\hline 200 & E. & ow & 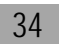 & 32 & 29 & $3=$ & 33 & 35 & 3 & 30 & 28 & $2 y$ & 24 & 3 & $\angle y$ & 27 & 22 & $\angle 8$ & 22 & 29 & $3<$ & 36 & sc & 30 & 26 & 20 & 35 & 38 & ju & 4 & - & - & - \\
\hline 200 & lar. & High & 63 & 5 & 61 & 60 & $5 s$ & 66 & 7 & 72 & 72 & 71 & -7 & 70 & 69 & 68 & 67 & 55 & 55 & 56 & 62 & 57 & 51 & 50 & 49 & 48 & 3 & 53 & 52 & 51 & 52 & 53 & $\infty$ \\
\hline 2005 & lar. & W & 36 & $u$ & 34 & 38 & 31 & 33 & $4 c$ & 39 & 37 & 38 & 38 & 42 & 33 & 29 & 30 & 38 & 30 & 3 & 44 & 39 & 36 & 38 & 41 & 38 & 37 & 45 & 42 & 2 & 40 & 38 & 38 \\
\hline 2005 & Apr. & High & 57 & - & 50 & 54 & 61 & 64 & 55 & 58 & 55 & 56 & 54 & $4 c$ & 55 & 55 & $\pi$ & 57 & 51 & 57 & 65 & 67 & 66 & 76 & 57 & 65 & 63 & 70 & 72 & 65 & 57 & 56 & - \\
\hline 2005 & pr. & Low & 43 & 3 & $\pi$ & 38 & 42 & $4:$ & 3 & $3 c$ & 33 & 36 & 39 & 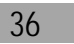 & 36 & 35 & 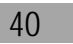 & 38 & 38 & 3 & 34 & 35 & 4( & 43 & 48 & 4 & 50 & 48 & 45 & 52 & DI & 6 & - \\
\hline 2005 & ay. & High & 69 & 68 & 74 & 70 & 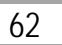 & 61 & 62 & 6 & 57 & 58 & 60 & 70 & 12 & 7 & 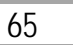 & 60 & 59 & 65 & 65 & 62 & 6 & 63 & 65 & 12 & 86 & $y_{1}$ & 90 & 68 & 62 & 4 & 63 \\
\hline 2005 & ayy. & & 41 & 4 & 45 & 5 & 5 & 50 & 5 & 50 & 48 & 4 & 42 & 42 & 53 & 56 & 5 & 48 & 48 & 50 & 49 & 44 & 4 & 45 & 41 & 38 & 47 & 52 & 53 & 3 & 51 & 54 & 50 \\
\hline 05 & Jun. & $\mathrm{H}$ & 63 & 66 & 69 & 65 & 58 & 57 & 59 & 71 & 76 & 67 & 6 & 67 & 70 & 65 & 71 & 68 & 68 & 72 & 80 & 78 & 70 & 71 & 75 & 79 & 77 & 66 & 63 & 69 & 79 & 83 & \\
\hline 05 & Jun. & Low & 49 & 4 & 50 & 46 & 4 & $4 i$ & 49 & 45 & 44 & 47 & 5. & 47 & 54 & 51 & 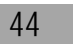 & 53 & 48 & 4 & 46 & 49 & 55 & 55 & 49 & 4 & 57 & 53 & 54 & 56 & 54 & 54 & - \\
\hline 2005 & Jul. & High & 78 & 72 & 79 & 83 & 8 & 74 & 74 & 0 & 71 & 70 & 76 & 76 & t5 & 86 & 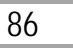 & 79 & 94 & 95 & 86 & 86 & 90 & 80 & 84 & 80 & 84 & 96 & 98 & 0 & 90 & 2 & 92 \\
\hline US & Jul. & L & 54 & 55 & 48 & 5 & - & 58 & 54 & 5 & 55 & 55 & b. & 59 & 5 & 53 & $\pi$ & 53 & 56 & 6 & 55 & 53 & 5 & 59 & 54 & 5 & 49 & Jy & 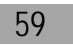 & 50 & 53 & 6 & 54 \\
\hline & & & 7 & 83 & 9 & 9 & 9 & 88 & 8 & 8 & 87 & 8 & 80 & 82 & 9 & 9 & & & & & & 89 & 0 & & $\pi$ & & & & & & 70 & 76 & 82 \\
\hline 2005 & ug. & Low & 58 & 5 & 50 & 54 & 5 & 58 & u & U & 5 & 5 & 5 & 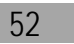 & 5. & 5 & 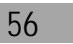 & & 5 & 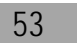 & 53 & 51 & 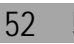 & 55 & 52 & 4 & 48 & 50 & 49 & 51 & 51 & 0 & 52 \\
\hline 2005 & Sep. & High & 88 & 78 & 78 & 75 & 77 & 80 & 87 & 8 & 65 & 6 & 71 & 76 & 77 & 77 & 71 & 60 & 68 & 74 & 76 & 73 & 75 & 69 & 71 & 69 & 75 & 78 & 73 & 78 & 79 & 99 & - \\
\hline 05 & Sep. & Lo & 5 & 5 & 5 & 5 & 46 & $4 \varepsilon$ & 5 & 5 & 40 & 4 & 4 & 47 & 46 & 47 & 5 & 40 & 46 & 4. & 42 & 47 & 4 & 39 & 40 & & 37 & & 47 & 41 & 45 & 35 & 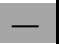 \\
\hline & JCt & & 6 & 5 & 5 & 6 & 0 & 6 & 6 & 6 & 6 & & 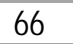 & & & $\lambda$ & & & & & & & & & & & & & & JI & 54 & 7 & 59 \\
\hline $2 C$ & Oct & & $+i$ & 42 & 40 & $\pi$ & 5 & 4 & 45 & 40 & 41 & 4. & 4 & $4 c$ & 40 & 50 & 5 & & 44 & & & $4 y$ & & 44 & 48 & & ou & & 34 & 43 & 40 & 37 & 53 \\
\hline 2005 & Nov & 1 & - & - & - & - & - & - & - & - & - & - & - & - & - & - & - & - & - & - & - & - & - & - & - & - & - & - & - & - & - & - & - \\
\hline 2005 & Nov & La & - & - & - & - & - & - & - & - & - & - & - & - & - & - & - & - & - & - & - & - & - & - & - & - & - & - & - & - & - & - & - \\
\hline US & Je & $\lg$ & - & - & - & - & 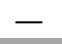 & - & - & - & - & - & - & - & - & - & - & 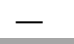 & - & - & - & - & - & - & - & - & - & - & - & - & - & - & - \\
\hline .005 & Uec. & Low & - & - & - & - & - & - & - & - & - & - & - & - & - & - & - & - & - & - & - & - & $=$ & - & - & - & - & - & - & - & - & - & \\
\hline
\end{tabular}


Appendix C2.

Average Temperature in the Willamette Valley and Southwest Washington 1971-2010

$\begin{array}{ccccccccccc}\text { January } & \text { February } & \text { March } & \text { April } & \text { May } & \text { June } & \text { July } & \text { August } & \text { September } & \text { October } & \text { November December } \\ 46.5 & 50.7 & 55.9 & 60.6 & 66.8 & 73.3 & 81.5 & 81.9 & 76.6 & 64.6 & 52.1\end{array}$

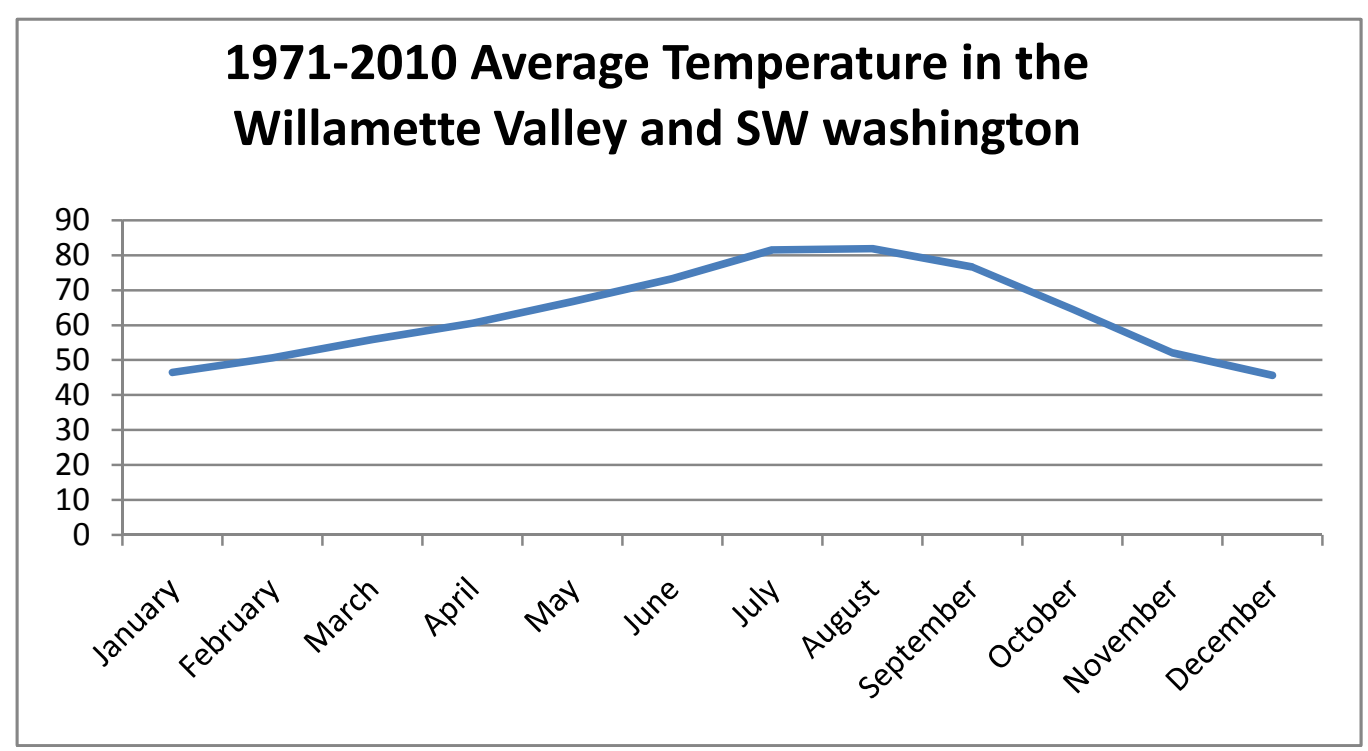


Appendix C3. Top 5 Warmest and Coldest Months, Years and Seasons Portland AIRPORT (Oct 1940 through May 2009)

\begin{tabular}{|c|c|c|c|c|c|c|c|}
\hline & \multicolumn{2}{|c|}{ Average MAX } & \multicolumn{3}{|c|}{ Average MIN } & \multicolumn{2}{|c|}{ Average MEAN } \\
\hline & warmest & coldest & warmest & \multicolumn{2}{|c|}{ coldest } & warmest & coldest \\
\hline \multirow{6}{*}{ January } & 52.01953 & 32.81950 & 42.61953 & 21.0 & 1949 & 47.31953 & 27.01950 \\
\hline & 51.21981 & 34.61949 & 40.82006 & 21.2 & 1950 & 45.52006 & 27.81949 \\
\hline & 50.72003 & 35.41979 & 38.82003 & 25.9 & 1957 & 44.72003 & 30.71979 \\
\hline & 50.51992 & 36.41969 & 38.81994 & 26.0 & 1979 & 44.41994 & 31.21957 \\
\hline & 50.41983 & 36.51957 & 38.51995 & 26.3 & 1943 & 44.41992 & 31.91969 \\
\hline & \multicolumn{2}{|c|}{ Climatic Normal 45.6} & \multicolumn{3}{|c|}{ Climatic Normal 34.2} & \multicolumn{2}{|c|}{ Climatic Normal 39.5} \\
\hline & \multicolumn{7}{|c|}{ Portland Int'l Airport Data } \\
\hline \multirow{6}{*}{ February } & 57.81968 & 40.91956 & 42.61958 & 28.5 & 1989 & 48.81991 & 35.81956 \\
\hline & 57.71991 & 43.51989 & 41.61961 & 30.6 & 1964 & 48.61958 & 36.01989 \\
\hline & 56.21992 & 45.21949 & 41.21983 & 30.8 & 1956 & 48.21968 & 38.81950 \\
\hline & 55.31963 & 45.51950 & 40.41998 & 32.1 & 1950 & 48.11992 & 39.11949 \\
\hline & 55.11941 & 46.91969 & 40.21963 & 32.4 & 1969 & 47.81963 & 39.71969 \\
\hline & \multicolumn{2}{|c|}{ Climatic Normal 50.3} & \multicolumn{3}{|c|}{ Climatic Normal 35.9} & \multicolumn{2}{|c|}{ Climatic Normal 43.2} \\
\hline \multicolumn{8}{|c|}{ Portland Int'l Airport Data } \\
\hline \multirow{6}{*}{ March } & 63.71992 & 49.21955 & 43.71983 & 33.6 & 1954 & 52.31992 & 41.51955 \\
\hline & 63.51941 & 49.41951 & 43.11984 & 33.8 & 1955 & 52.01941 & 41.91951 \\
\hline & 60.91994 & 51.51950 & 42.52007 & 34.1 & 1969 & 51.22004 & 43.71971 \\
\hline & 60.51986 & 51.81956 & 42.12003 & 34.5 & 1951 & 51.21986 & 43.81964 \\
\hline & 60.51979 & 51.91967 & 42.02004 & 35.4 & 1971 & 51.11984 & 43.81954 \\
\hline & \multicolumn{2}{|c|}{ Climatic Normal 55.7} & \multicolumn{3}{|c|}{ Climatic Normal 38.6} & \multicolumn{2}{|c|}{ Climatic Normal 47.4} \\
\hline \multicolumn{8}{|c|}{ Portland Int'l Airport Data } \\
\hline \multirow{6}{*}{ April } & 67.32004 & 55.01955 & 46.51992 & 37.4 & 1964 & 56.32004 & 46.51955 \\
\hline & 66.81989 & 55.91963 & 45.32004 & 37.6 & 1967 & 56.01989 & 46.71964 \\
\hline & 66.01951 & 56.01964 & 45.21996 & 37.9 & 1955 & 55.41992 & 46.91967 \\
\hline & 65.81941 & 56.21967 & 45.21993 & 38.0 & 1975 & 54.51990 & 47.31975 \\
\hline & 65.31977 & 56.51948 & 45.21989 & 38.2 & 1968 & 54.51941 & 48.01972 \\
\hline & Climatic Nc & al 60.5 & Climatic Nor & 141.9 & & Climatic Norn & 51.9 \\
\hline & Portland Int & lirport Data & & & & & \\
\hline & 76.61992 & 61.11962 & 51.82005 & 41.9 & 1964 & 63.11992 & 52.61964 \\
\hline & 73.41958 & 62.31991 & 51.72004 & 42.8 & 1955 & 62.21997 & 52.91955 \\
\hline & 73.31947 & 62.31977 & 51.71997 & 43.2 & 1950 & 61.81958 & 53.81977 \\
\hline May & 72.61997 & 62.41960 & 50.91993 & 44.0 & 1965 & \begin{tabular}{|l|}
61.31947 \\
\end{tabular} & 53.91962 \\
\hline & 71.61995 & 62.71998 & 50.41983 & 44.3 & 1966 & 61.11993 & 53.91960 \\
\hline & Climatic Nc & al 66.7 & Climatic Nor & 147.5 & & Climatic Norn & 57.8 \\
\hline & Portland Int & irport Data & & & & & \\
\hline & 79.51992 & 66.21954 & 57.11948 & 49.0 & 1964 & 67.41992 & 57.91954 \\
\hline & 79.31987 & 66.41953 & 56.91969 & 49.7 & 1965 & 66.51987 & 58.61953 \\
\hline & 77.91970 & 67.61956 & 56.81958 & 49.7 & 1954 & 66.51969 & 58.71964 \\
\hline June & 77.51967 & 68.31991 & 56.42006 & 49.9 & 1976 & 66.51948 & 59.01956 \\
\hline & 77.41986 & 68.41964 & 55.22004 & 50.4 & 1956 & 66.32006 & 59.91991 \\
\hline & Climatic No & al 72.7 & Climatic Nor & 152.6 & & Climatic Norn & 63.2 \\
\hline & Portland Int & lirport Data & & & & & \\
\hline & 87.51985 & 72.01963 & 61.21998 & 53.1 & 1964 & \begin{tabular}{|l|l|}
74.11985 \\
\end{tabular} & 63.01963 \\
\hline & 84.72003 & 72.21955 & 60.71985 & 53.5 & 1954 & 72.01996 & 63.01954 \\
\hline & 84.71996 & 72.61954 & 59.92007 & 53.8 & 1962 & 71.62003 & 63.41955 \\
\hline July & 84.61994 & 72.81993 & 59.62004 & 54.1 & 1963 & 71.52004 & 64.31993 \\
\hline & 84.51941 & 75.01989 & 59.52006 & 54.4 & 1953 & 71.41941 & 64.51964 \\
\hline & Climatic Nc & al 79.3 & Climatic Nor & 156.9 & & Climatic Norn & 68.2 \\
\hline
\end{tabular}




\begin{tabular}{|c|c|c|c|c|c|c|c|}
\hline & \multicolumn{2}{|c|}{ Average MAX } & \multicolumn{3}{|c|}{ Average MIN } & \multicolumn{2}{|c|}{ Average MEAN } \\
\hline & \multirow{2}{*}{$\begin{array}{l}\text { warmest } \\
88.11967 \\
\end{array}$} & \multirow{2}{*}{$\begin{array}{l}\text { coldest } \\
71.61954\end{array}$} & \multirow{2}{*}{$\begin{array}{c}\text { warmest } \\
60.72004 \\
\end{array}$} & \multicolumn{2}{|c|}{ coldest } & \multirow{2}{*}{$\begin{array}{c}\text { warmest } \\
72.91967 \\
\end{array}$} & \multirow{2}{*}{$\begin{array}{l}\text { coldest } \\
63.31954 \\
\end{array}$} \\
\hline \multirow{6}{*}{ August } & & & & 52.2 & 1964 & & \\
\hline & 86.21986 & 74.21948 & 60.41997 & 53.4 & 1951 & 72.31986 & 63.71964 \\
\hline & 85.51981 & 74.31976 & 59.61990 & 53.7 & 1969 & 72.11981 & 64.51957 \\
\hline & 85.01972 & 75.21964 & 59.61971 & 53.7 & 1955 & 71.71977 & 65.31975 \\
\hline & 84.11977 & 75.21957 & 59.51999 & 53.8 & 1959 & 71.71972 & 65.41960 \\
\hline & \multicolumn{2}{|c|}{ Climatic Normal 79.7} & \multicolumn{3}{|c|}{ Climatic Normal 57.3} & \multicolumn{2}{|c|}{ Climatic Normal 68.5} \\
\hline & \multicolumn{7}{|c|}{ Portland Int'l Airport Data } \\
\hline \multirow{6}{*}{ Sept. } & 81.91974 & 68.81941 & 56.61995 & 46.5 & 1964 & 67.61994 & 58.41964 \\
\hline & 81.41991 & 69.01978 & 56.01997 & 47.9 & 1965 & 67.41991 & 59.51961 \\
\hline & 80.11993 & 69.31959 & 56.01990 & 47.9 & 1961 & 67.31974 & 60.21954 \\
\hline & 80.01967 & 69.71977 & 55.81994 & 48.9 & 1955 & 67.11995 & 60.31959 \\
\hline & 79.71989 & 69.91954 & 55.21979 & 49.3 & 1950 & 67.01990 & 60.41965 \\
\hline & \multicolumn{2}{|c|}{ Climatic Normal 74.6} & \multicolumn{3}{|c|}{ Climatic Normal 52.5} & \multicolumn{2}{|c|}{ Climatic Normal 63.6} \\
\hline & \multicolumn{7}{|c|}{ Portland Int'l Airport Data } \\
\hline \multirow{6}{*}{ October } & 71.91987 & 57.61949 & 50.42003 & 39.5 & 1949 & 58.61952 & 48.51949 \\
\hline & 71.81952 & 58.71950 & 49.92005 & 41.9 & 1972 & 58.51944 & 50.61946 \\
\hline & 67.91944 & 58.81946 & 49.81988 & 41.9 & 1964 & 58.31988 & 51.71956 \\
\hline & 67.81974 & 59.01956 & 49.51979 & 42.3 & 1970 & 58.22003 & 52.01968 \\
\hline & 67.71993 & 59.81984 & 49.11944 & 42.5 & 1978 & 58.21987 & 52.41971 \\
\hline & Climatic No & al 63.3 & Climatic Nor & 145.2 & & Climatic Norm & \\
\hline & Portland Int' & iirport Data & & & & & \\
\hline & 58.41949 & 42.91985 & 46.21995 & 31.2 & 1978 & 51.71995 & 37.21985 \\
\hline & 57.11995 & 46.91978 & 44.71983 & 31.6 & 1985 & 50.11999 & 39.11978 \\
\hline Nevember & 56.41981 & 46.91955 & 44.41998 & 31.8 & 1952 & 49.91949 & 40.71952 \\
\hline November & 56.11976 & 47.61964 & 44.21999 & 33.8 & 1993 & 49.81997 & 41.01964 \\
\hline & 56.01999 & 48.31994 & 43.71997 & 34.4 & 1964 & 49.71965 & 41.41955 \\
\hline & Climatic No & al 51.8 & Climatic Nor & 39.8 & & Climatic Norm & \\
\hline & Portland Int' & irport Data & & & & & \\
\hline & 51.41950 & 39.21985 & 41.41950 & 26.8 & 1985 & 46.41950 & 33.01985 \\
\hline & 50.21980 & 40.01990 & \begin{tabular}{|l|}
39.71973 \\
\end{tabular} & 28.9 & 1978 & 44.71973 & 34.71990 \\
\hline & 49.91979 & 40.21983 & \begin{tabular}{|l|}
39.51966 \\
\end{tabular} & 29.4 & 1990 & 44.41979 & 35.21978 \\
\hline December & 49.61974 & 41.61978 & 38.91979 & 31.4 & 1964 & 44.21966 & 36.31983 \\
\hline & 49.61973 & 42.21968 & 38.71999 & 31.7 & 1972 & 44.11974 & 37.01964 \\
\hline & Climatic No & al 45.4 & Climatic Nor & 135.0 & & Climatic Norm & \\
\hline & Portland Int' & irport Data & & & & & \\
\hline & 65.81992 & 58.71955 & 47.42004 & 40.8 & 1964 & 56.21992 & 50.11964 \\
\hline & 65.21987 & 59.41964 & 47.41998 & 42.3 & 1955 & 55.72004 & 50.51955 \\
\hline & 64.71958 & 60.01954 & 47.02003 & 42.7 & 1949 & 55.71995 & 51.61950 \\
\hline Annual & \begin{tabular}{|l|}
64.61994 \\
\end{tabular} & 60.21956 & \begin{tabular}{|l|}
46.91995 \\
\end{tabular} & 43.0 & 1950 & 55.62003 & 51.71956 \\
\hline & \begin{tabular}{|l}
64.51995 \\
\end{tabular} & 60.21948 & \begin{tabular}{|l|}
46.81983 \\
\end{tabular} & 43.1 & 1985 & 55.31998 & 51.71954 \\
\hline & Climatic No & al 62.1 & Climatic Nor & 144.8 & & Climatic Norm & \\
\hline & Portland Int' & iirport Data & & & & & \\
\hline & $66.41991-2$ & $59.71954-5$ & $47.52003-4$ & 41.5 & 1963-4 & 56.6 1991-2 & 50.7 1963-4 \\
\hline & 65.0 1993-4 & $59.81963-4$ & 47.4 1997-8 & 42.0 & $1949-0$ & $55.72003-4$ & $51.11949-0$ \\
\hline der & 64.8 1986-7 & $60.01955-6$ & $46.71991-2$ & 42.6 & $1964-5$ & $55.52002-3$ & $51.31954-5$ \\
\hline & $64.42002-3$ & 60.2 1949-0 & $46.62002-3$ & 42.6 & $1948-9$ & 55.3 1997-8 & 51.4 1948-9 \\
\hline to Sept 30 & 64.4 1980-1 & 60.3 1953-4 & $46.61982-3$ & 42.8 & $1954-5$ & 55.3 1993-4 & $51.71955-6$ \\
\hline & Climatic No & al 62.1 & Climatic Nor & 94.8 & & Climatic Norm & \\
\hline
\end{tabular}


Top 5 Warmest and Coldest Seasons and Averages Portland AIRPORT (Oct 1940 through May 2009)

\begin{tabular}{|c|c|c|c|c|c|c|c|}
\hline \multirow{8}{*}{$\begin{array}{l} \\
\text { Winter } \\
\text { Season } \\
\text { (Dec 22- } \\
\text { Mar 21) }\end{array}$} & \multicolumn{2}{|c|}{ Average MAX } & \multicolumn{3}{|c|}{ Average MIN } & \multicolumn{2}{|c|}{ Average MEAN } \\
\hline & \multirow{2}{*}{$\begin{array}{l}\text { warmest } \\
54.8 \text { 1991-2 }\end{array}$} & \multirow{2}{*}{$\begin{array}{l}\text { coldest } \\
\mathbf{4 2 . 8} 1949-0\end{array}$} & \multirow{2}{*}{$\begin{array}{l}\text { warmest } \\
39.5 \text { 1982-3 }\end{array}$} & \multicolumn{2}{|c|}{ coldest } & \multirow{2}{*}{$\begin{array}{c}\text { warmest } \\
\mathbf{4 7 . 0} 1991-2 \\
\end{array}$} & \multirow{2}{*}{$\begin{array}{l}\text { coldest } \\
36.31948-9\end{array}$} \\
\hline & & & & 29.9 & 1948-9 & & \\
\hline & $53.81980-1$ & $42.81948-9$ & $39.21997-8$ & 30.1 & 1968-9 & $45.91982-3$ & $36.81949-0$ \\
\hline & 53.4 1940-1 & $44.11968-9$ & 39.2 1991-2 & 30.7 & 1949-0 & 45.7 1980-1 & $37.11968-9$ \\
\hline & $53.02004-5$ & $44.81956-7$ & $39.02002-3$ & 31.8 & $1956-7$ & 45.4 1994-5 & $38.31956-7$ \\
\hline & $52.41982-3$ & $45.01955-6$ & $38.71952-3$ & 31.8 & $1942-3$ & $45.31940-1$ & $39.11978-9$ \\
\hline & \multicolumn{2}{|l|}{ average 49.1} & \multicolumn{3}{|l|}{ average 35.6} & \multicolumn{2}{|l|}{ average 42.3} \\
\hline & \multicolumn{7}{|c|}{ Portland Int'l Airport Data } \\
\hline \multirow{6}{*}{$\begin{array}{l}\text { Deep } \\
\text { Winter } \\
\text { (Dec 1- } \\
\text { Feb 14) }\end{array}$} & $50.32002-3$ & $38.81948-9$ & 39.5 1952-3 & 27.7 & 1948-9 & $44.81952-3$ & 33.2 1948-9 \\
\hline & $50.31991-2$ & $39.41949-0$ & 38.8 1957-8 & 28.4 & $1949-0$ & $44.51957-8$ & $33.91949-0$ \\
\hline & $50.31957-8$ & $40.11968-9$ & $38.31950-1$ & 29.1 & 1978-9 & $44.12002-3$ & $34.71978-9$ \\
\hline & $50.11952-3$ & $40.31978-9$ & $38.21966-7$ & 30.6 & $1968-9$ & $44.11991-2$ & $35.31968-9$ \\
\hline & $49.81980-1$ & $42.41956-7$ & $38.12005-6$ & 30.8 & 1956-7 & $43.81966-7$ & $36.61956-7$ \\
\hline & \multicolumn{2}{|c|}{ average 46.3} & \multicolumn{3}{|l|}{ average 34.8} & \multicolumn{2}{|l|}{ average 40.6} \\
\hline & Portland Int'l & port Data & & & & & \\
\hline \multirow{6}{*}{$\begin{array}{l}\text { Spring } \\
\text { Season } \\
\text { (Mar 22- } \\
\text { June 21) }\end{array}$} & 71.51992 & 61.01964 & 49.32004 & 41.5 & 1964 & 60.11992 & 51.21964 \\
\hline & 68.92004 & 61.31955 & 48.71992 & 42.4 & 1955 & 59.12004 & 51.91955 \\
\hline & 68.91987 & 61.71953 & 48.32005 & 43.4 & 1954 & 58.01994 & 53.01953 \\
\hline & 68.91969 & 62.22008 & 48.31993 & 43.4 & 1950 & 57.81987 & 53.11954 \\
\hline & 68.31994 & 62.31991 & 48.22006 & 43.8 & 1966 & 57.71958 & 53.11950 \\
\hline & \multicolumn{2}{|l|}{ average 65.3} & average 45.9 & & & average 55.6 & \\
\hline & Portland Int & irport Data & & & & & \\
\hline & 83.61967 & 71.21954 & 58.81998 & 50.8 & 1964 & 69.81990 & 62.31954 \\
\hline Summer & 81.81994 & 73.51955 & 58.62004 & 53.2 & 1955 & 69.81967 & 62.51964 \\
\hline Season & 81.61972 & 73.81963 & 58.21997 & 53.3 & 1957 & 69.71998 & 63.41955 \\
\hline (June 22- & 81.52005 & 74.31964 & 58.21990 & 53.3 & 1954 & 69.42003 & 64.11963 \\
\hline Sept 21) & 81.41990 & 75.21983 & 57.51995 & 53.6 & 1951 & 69.31994 & 64.91957 \\
\hline & average 78.4 & & average 55.6 & & & average 67.0 & \\
\hline & Portland Int'l & port Data & & & & & \\
\hline & 85.41967 & 72.11954 & 60.21998 & 52.6 & 1964 & 71.71985 & 63.21954 \\
\hline Deep & 84.51972 & 74.31963 & 60.12004 & 54.1 & 1957 & 71.52004 & 64.11964 \\
\hline Summer & 84.21985 & 74.71955 & 59.41997 & 54.2 & 1955 & 71.31972 & 64.41955 \\
\hline (July 1 - & 83.51996 & 75.21989 & 59.11985 & 54.2 & 1954 & 71.21996 & 64.61963 \\
\hline Aug 31) & 83.41994 & 75.51948 & 59.01990 & 54.4 & 1969 & 71.11967 & 65.01957 \\
\hline & average 79.8 & & average 56.8 & & & average 68.3 & \\
\hline & Portland Int'l & port Data & & & & & \\
\hline & 61.31987 & 51.91985 & 45.01995 & 36.5 & 1985 & 52.01974 & 44.21985 \\
\hline Autumn & 61.31974 & 53.41955 & 44.52003 & 37.1 & 1964 & 51.91995 & 45.61964 \\
\hline Season & 59.51952 & 54.01984 & 44.41988 & 37.4 & 1978 & 51.81999 & 46.51978 \\
\hline (Sept 22- & 59.41991 & 54.01948 & 44.31947 & 38.4 & 1961 & 51.81987 & 46.61955 \\
\hline Dec 21) & 59.41965 & 54.11964 & 44.12004 & 38.5 & 1972 & 51.72003 & 46.11961 \\
\hline & average 56.9 & & average 41.7 & & & average 49.3 & \\
\hline & Portland Int'l & port Data & & & & & \\
\hline & 75.31952 & 65.41956 & 52.72003 & 44.2 & 1964 & 62.42003 & 55.71949 \\
\hline Early & 75.11987 & 65.51946 & 52.31979 & 45.3 & 1949 & 62.11979 & 55.81964 \\
\hline Autumn & 74.81974 & 65.61941 & 51.42004 & 45.6 & 1972 & 61.81987 & 56.21956 \\
\hline (Sept 1 - & 74.01991 & 66.01985 & 51.31997 & 45.7 & 1970 & 61.81944 & 56.21946 \\
\hline Oct 31) & 73.81993 & 66.01968 & 51.11995 & 45.9 & 1961 & 61.71952 & 56.31961 \\
\hline & average 69.1 & & average 48.6 & & & average 58.9 & \\
\hline
\end{tabular}




\section{Portland Airport, Oregon}

NORMALS, MEANS, AND EXTREMES

LATITUDE: 45 Deg. 36 Min. N LONGITUDE: 122 Deg. 36 Min. W ELEVATION: FT. GRND 21 BARO 27 TIME ZONE: PACIFIC WBAN: 24229

\begin{tabular}{|c|c|c|c|c|c|c|c|c|c|c|c|c|c|c|}
\hline & (a) & JAN & FEB & MAR & APR & MAY & JUN & JUL & AUG & SEP & OCT & NOV & DEC & YEAR \\
\hline $\begin{array}{l}\text { TEMPERATURE (Deg. F) } \\
\text { Normals } \\
\text {-Daily Maximum } \\
\text {-Daily Minimum } \\
\text {-Monthly } \\
\text { Extremes } \\
\text {-Record Highest } \\
\text {-Year } \\
\text {-Record Lowest } \\
\text {-Year }\end{array}$ & 55 & $\begin{array}{c}45.4 \\
33.7 \\
39.6 \\
\\
63 \\
1986 \\
-2 \\
1950\end{array}$ & $\begin{array}{c}51.0 \\
36.1 \\
43.6 \\
\\
71 \\
1988 \\
-3 \\
1950\end{array}$ & $\begin{array}{c}56.0 \\
38.6 \\
47.3 \\
\\
80 \\
1947 \\
19 \\
1989\end{array}$ & $\begin{array}{c}60.6 \\
41.3 \\
51.0 \\
\\
87 \\
1957 \\
29 \\
1955\end{array}$ & $\begin{array}{c}67.1 \\
47.0 \\
57.1 \\
\\
100 \\
1983 \\
29 \\
1954 \\
\end{array}$ & $\begin{array}{c}74.0 \\
52.9 \\
63.5 \\
\\
100 \\
1992 \\
39 \\
1966\end{array}$ & $\begin{array}{c}79.9 \\
56.5 \\
68.2 \\
\\
107 \\
1965 \\
43 \\
1955\end{array}$ & $\begin{array}{c}80.3 \\
56.9 \\
68.6 \\
\\
107 \\
1981 \\
44 \\
1980 \\
\end{array}$ & $\begin{array}{c}74.6 \\
52.0 \\
63.3 \\
\\
105 \\
1988 \\
34 \\
1965\end{array}$ & $\begin{array}{c}64.0 \\
44.9 \\
54.5 \\
\\
92 \\
1987 \\
26 \\
1971\end{array}$ & $\begin{array}{c}52.6 \\
39.5 \\
46.1 \\
\\
73 \\
1975 \\
13 \\
1985 \\
\end{array}$ & $\begin{array}{c}45.6 \\
34.8 \\
40.2 \\
\\
65 \\
1993 \\
6 \\
1964 \\
\end{array}$ & $\begin{array}{c}62.6 \\
44.5 \\
53.6 \\
\\
107 \\
\text { AUG } 1981 \\
-3 \\
\text { FEB } 1950\end{array}$ \\
\hline $\begin{array}{l}\text { NORMAL DEGREE DAYS } \\
\text { Heating (base } 65 \text { Deg. F) } \\
\text { Cooling (base } 65 \text { Deg. F) }\end{array}$ & & $\begin{array}{c}787 \\
0\end{array}$ & $\begin{array}{c}599 \\
0\end{array}$ & $\begin{array}{c}549 \\
0\end{array}$ & $\begin{array}{c}420 \\
0\end{array}$ & $\begin{array}{c}249 \\
0\end{array}$ & $\begin{array}{l}91 \\
46\end{array}$ & $\begin{array}{c}28 \\
127\end{array}$ & $\begin{array}{c}35 \\
147\end{array}$ & $\begin{array}{c}102 \\
51\end{array}$ & $\begin{array}{c}326 \\
0\end{array}$ & $\begin{array}{c}567 \\
0\end{array}$ & $\begin{array}{c}769 \\
0\end{array}$ & $\begin{array}{c}4522 \\
371\end{array}$ \\
\hline$\%$ OF POSSIBLE SUNSHINE & 46 & 29 & 38 & 48 & 52 & 57 & 56 & 69 & 66 & 62 & 44 & 28 & 23 & 48 \\
\hline $\begin{array}{l}\text { MEAN SKY COVER(tenths) } \\
\text { Sunrise - Sunset } \\
\text { MEAN NUMBER OF DAYS: } \\
\text { Sunrise to Sunset } \\
\text {-Clear } \\
\text {-Partly Cloudy } \\
\text {-Cloudy } \\
\text { Precipitation } \\
.01 \text { inches or more } \\
\text { Snow, Ice Pellets, Hail } \\
1.0 \text { inches or more }\end{array}$ & $\begin{array}{l}47 \\
47 \\
47\end{array}$ & $\begin{array}{c}2.9 \\
3.6 \\
24.4 \\
18.0 \\
\\
1.0\end{array}$ & $\begin{array}{c}2.9 \\
3.8 \\
21.5 \\
15.6 \\
\\
0.3\end{array}$ & $\begin{array}{c}3.3 \\
4.9 \\
22.8 \\
\\
16.9 \\
0.1\end{array}$ & $\begin{array}{c}3.5 \\
5.8 \\
20.7 \\
\\
14.4 \\
0.0\end{array}$ & $\begin{array}{c}5.0 \\
7.2 \\
18.9 \\
11.8 \\
0 . *\end{array}$ & $\begin{array}{c}6.2 \\
7.7 \\
16.1 \\
\\
9.2 \\
0.0\end{array}$ & $\begin{array}{c}12.6 \\
8.5 \\
9.9 \\
3.9\end{array}$ & $\begin{array}{c}11.4 \\
9.6 \\
10.1 \\
4.9\end{array}$ & $\begin{array}{c}10.3 \\
8.1 \\
11.6 \\
7.5\end{array}$ & $\begin{array}{c}5.4 \\
7.6 \\
18.0 \\
\\
12.3 \\
0.0\end{array}$ & $\begin{array}{c}2.8 \\
4.3 \\
22.9 \\
\\
18.0 \\
0.1\end{array}$ & $\begin{array}{c}2.1 \\
3.3 \\
25.5 \\
\\
18.7 \\
\\
0.5\end{array}$ & $\begin{array}{c}68.4 \\
74.5 \\
222.4 \\
150.9 \\
2.1\end{array}$ \\
\hline
\end{tabular}




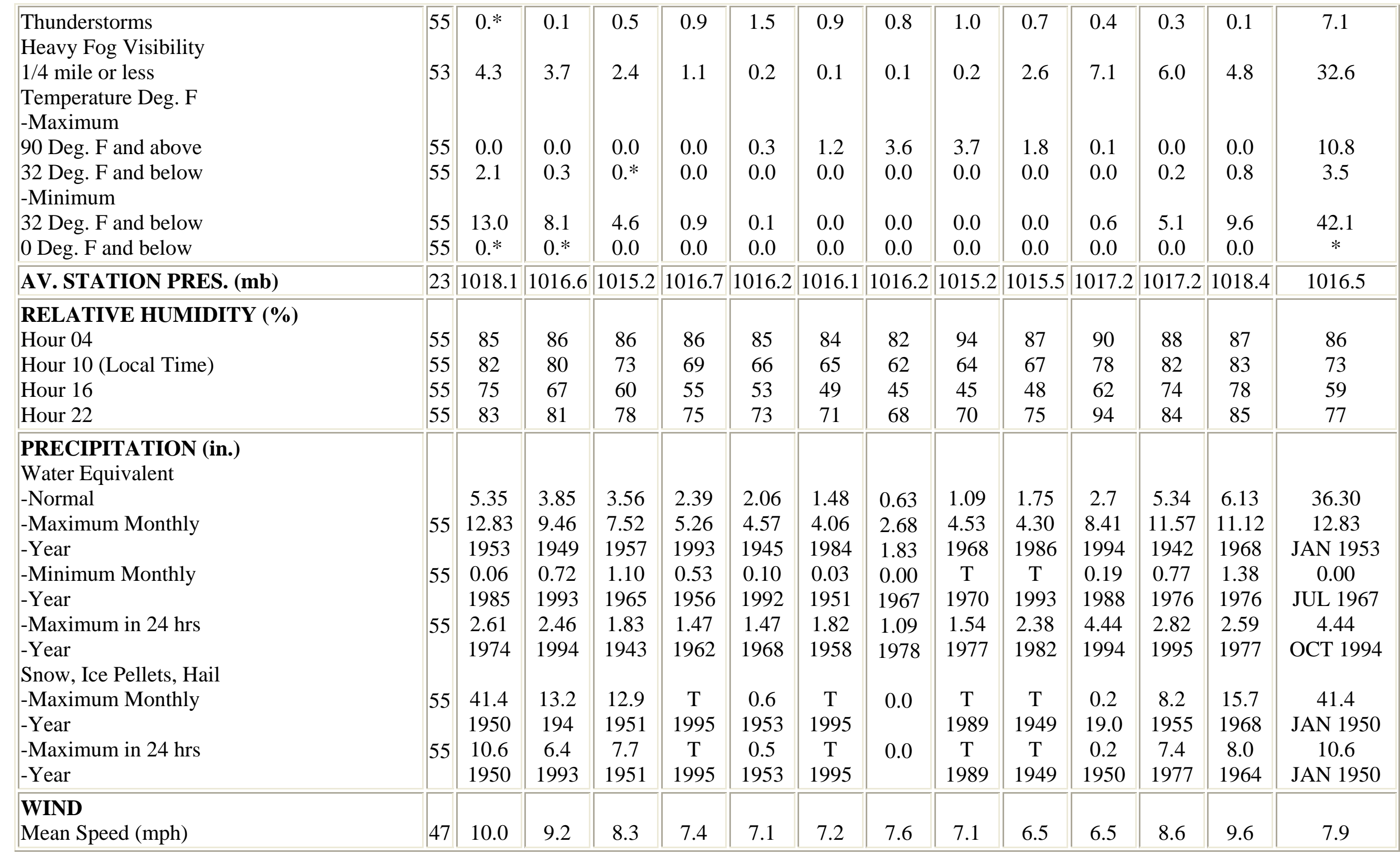




\begin{tabular}{|c|c|c|c|c|c|c|c|c|c|c|c|c|c|c|}
\hline $\begin{array}{l}\text { Prevailing Direction } \\
\text { through } 1964 \\
\text { Fastest Mile }\end{array}$ & & ESE & ESE & ESE & NW & NW & NW & NW & NW & NW & ESE & ESE & ESE & ESE \\
\hline -Direction(!!) & 41 & S & SW & S & S & SW & SW & SW & SW & S & S & SW & S & S \\
\hline -Speed(mph) & 41 & 54 & 61 & 57 & 60 & 42 & 40 & 33 & 29 & 61 & 88 & 56 & 57 & 88 \\
\hline $\begin{array}{l}\text {-Year } \\
\text { Peak Gust }\end{array}$ & & 1951 & 1958 & 1963 & 1957 & 1960 & 1958 & 1983 & 1961 & 1963 & 1962 & 1961 & 1951 & OCT 1962 \\
\hline -Direction(!!) & 12 & SW & SE & S & SW & W & SW & NW & SW & $\mathrm{E}$ & S & SW & 17 & 17 \\
\hline -Speed(mph) & 12 & 63 & 61 & 59 & 45 & 46 & 40 & 32 & 31 & 44 & 52 & 52 & 71 & 71 \\
\hline -Date & & 1990 & 1989 & 1995 & 1992 & 1993 & 1994 & 1992 & 1995 & 1995 & 1994 & 1984 & 1995 & DEC 1995 \\
\hline
\end{tabular}

(a) - Length of Record in Years, although individual months may be missing.

$0 . *$ or * - The value is between 0.0 and 0.05 .

Normals - Based on the 1961 - 1990 record period.

Extremes - Dates are the most recent occurrence.

Wind Dir.- Numerals show tens of degrees clockwise from true north. "00" indicates calm.

Resultant Directions are given to whole degrees. 
Appendix C5

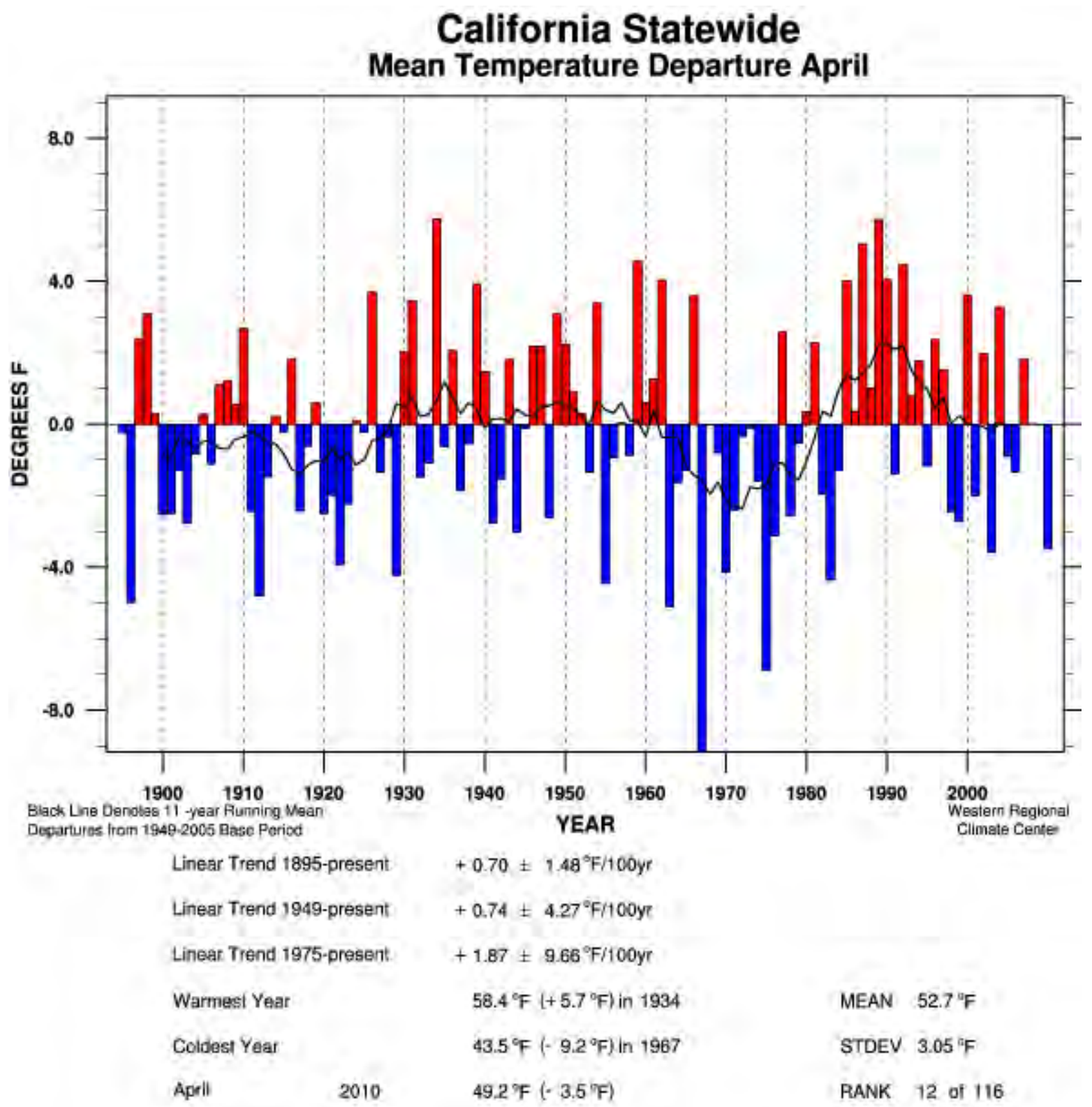




\title{
REDDING, CALIFORNIA
}

\author{
NORMALS, MEANS, AND EXTREMES
}

LATITUDE: 40 Deg. 30 Min. N LONGITUDE: 122 Deg. 18 Min. W ELEVATION: FT. GRND 502 BARO 536 TIME ZONE: PACIFIC WBAN: 24257

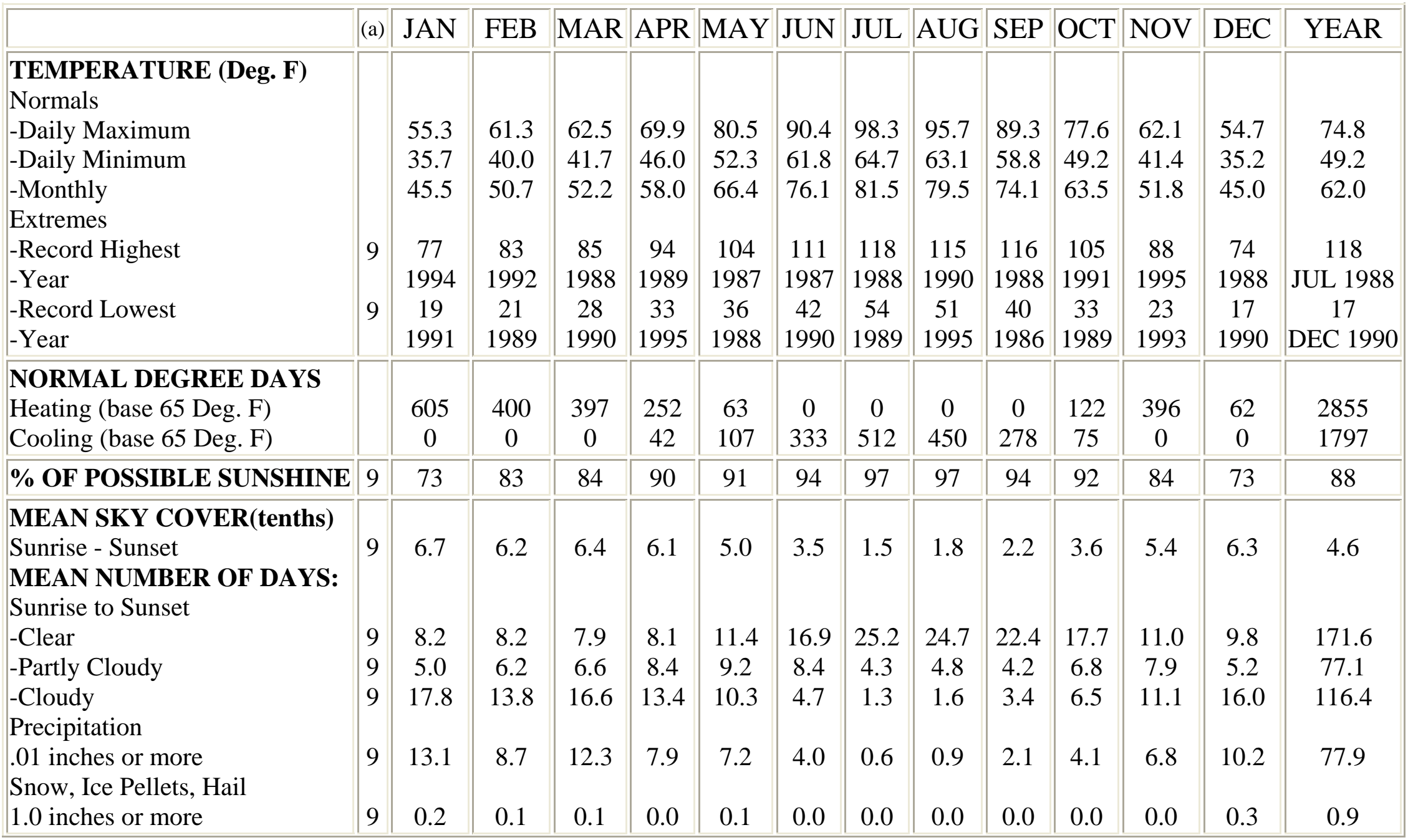




\begin{tabular}{|c|c|c|c|c|c|c|c|c|c|c|c|c|c|c|}
\hline $\begin{array}{l}\text { Thunderstorms } \\
\text { Heavy Fog Visibility } \\
1 / 4 \text { mile or less } \\
\text { Temperature Deg. F } \\
\text {-Maximum }\end{array}$ & 9 & $\begin{array}{l}0.6 \\
5.1\end{array}$ & 1.4 & 0.8 & 0.1 & 0.0 & 1.7 & 0.9 & 1.2 & $\begin{array}{l}0.8 \\
0.0\end{array}$ & 0.9 & 0.2 & 0.4 & 13.3 \\
\hline 90 Deg. $F$ and above & 9 & 0.0 & 0.0 & 0.0 & 1.1 & 6.2 & 16.2 & 27.6 & 25.4 & 18.6 & 6.7 & 0.0 & 0.0 & 101.9 \\
\hline $\begin{array}{l}32 \text { Deg. F and below } \\
\text {-Minimum }\end{array}$ & 9 & 0.0 & 0.0 & 0.0 & 0.0 & 0.0 & 0.0 & 0.0 & 0.0 & 0.0 & 0.0 & 0.0 & 0.1 & 0.1 \\
\hline and below & 9 & 11.8 & 6.3 & 1.7 & 0.0 & 0.0 & 0.0 & 0.0 & 0.0 & 0.0 & 0.0 & 3.3 & 13.9 & 37.0 \\
\hline 0 Deg & 9 & 0.0 & 0.0 & 0.0 & 0.0 & 0.0 & 0.0 & 0.0 & 0.0 & 0.0 & 0.0 & 0.0 & 0.0 & 0.0 \\
\hline AV. STATION PRES. (mb) & 9 & 1002.3 & 1000.7 & 998.7 & 998.0 & 995.6 & 994.5 & 994.1 & 994.0 & 995.1 & 997.7 & 1002.2 & 1002.5 & 997.9 \\
\hline $\begin{array}{l}\text { RELATIVE HUMIDITY (\%) } \\
\text { Hour } 04 \\
\text { Hour } 10 \text { (Local Time) } \\
\text { Hour } 16 \\
\text { Hour } 22\end{array}$ & $\begin{array}{l}9 \\
9 \\
9 \\
9\end{array}$ & $\begin{array}{l}84 \\
76 \\
58 \\
79\end{array}$ & $\begin{array}{l}81 \\
66 \\
46 \\
72\end{array}$ & $\begin{array}{l}80 \\
62 \\
48 \\
71\end{array}$ & $\begin{array}{l}77 \\
51 \\
38 \\
64\end{array}$ & $\begin{array}{l}73 \\
44 \\
33 \\
58\end{array}$ & $\begin{array}{l}64 \\
37 \\
25 \\
48\end{array}$ & $\begin{array}{l}58 \\
32 \\
19 \\
40\end{array}$ & $\begin{array}{l}59 \\
32 \\
18 \\
40\end{array}$ & $\begin{array}{l}61 \\
34 \\
22 \\
45\end{array}$ & $\begin{array}{l}68 \\
42 \\
30 \\
56\end{array}$ & $\begin{array}{l}79 \\
61 \\
45 \\
73\end{array}$ & $\begin{array}{l}83 \\
75 \\
58 \\
78\end{array}$ & $\begin{array}{l}72 \\
51 \\
37 \\
60\end{array}$ \\
\hline $\begin{array}{l}\text { PRECIPITATION (in.) } \\
\text { Water Equivalent } \\
\text {-Normal } \\
\text {-Maximum Monthly } \\
\text {-Year } \\
\text {-Minimum Monthly } \\
\text {-Year } \\
\text {-Maximum in } 24 \text { hrs } \\
\text {-Year } \\
\text { Snow, Ice Pellets, Hail } \\
\text {-Maximum Monthly } \\
\text {-Year } \\
\text {-Maximum in } 24 \text { hrs } \\
\text {-Year }\end{array}$ & 9 & $\begin{array}{c}6.06 \\
22.93 \\
1995 \\
0.89 \\
1991 \\
3.96 \\
1990 \\
\\
3.2 \\
1989 \\
2.0 \\
1989\end{array}$ & \begin{tabular}{|c|}
4.45 \\
10.15 \\
1992 \\
0.14 \\
1988 \\
2.14 \\
1992 \\
\\
1.4 \\
1990 \\
1.4 \\
1990
\end{tabular} & $\begin{array}{c}4.38 \\
14.7 \\
1995 \\
0.52 \\
1988 \\
3.18 \\
1995 \\
\\
1.8 \\
1987 \\
1.8 \\
1987\end{array}$ & $\begin{array}{c}2.08 \\
4.26 \\
1995 \\
0.14 \\
1987 \\
2.33 \\
1993 \\
\\
\mathrm{~T} \\
1995 \\
\mathrm{~T} \\
1995\end{array}$ & $\begin{array}{c}1.27 \\
6.72 \\
1993 \\
0.01 \\
1987 \\
3.79 \\
1993 \\
\\
1.5 \\
1990 \\
1.5 \\
1990\end{array}$ & $\begin{array}{c}0.56 \\
1.93 \\
1995 \\
\mathrm{~T} \\
1987 \\
1.24 \\
1988 \\
\\
\mathrm{~T} \\
1992 \\
\mathrm{~T} \\
1992\end{array}$ & $\begin{array}{c}0.17 \\
0.49 \\
1990 \\
0.00 \\
1990 \\
0.49 \\
1990 \\
0.0 \\
\\
0.0\end{array}$ & $\begin{array}{c}0.46 \\
1.06 \\
1990 \\
0.00 \\
1987 \\
0.83 \\
1993 \\
\\
\mathrm{~T} \\
1993 \\
\mathrm{~T} \\
1993\end{array}$ & $\begin{array}{c}0.91 \\
4.83 \\
1989 \\
0.00 \\
1988 \\
3.15 \\
1989 \\
0.0 \\
0.0\end{array}$ & \begin{tabular}{|c}
2.24 \\
6.26 \\
1992 \\
$\mathrm{~T}$ \\
1995 \\
4.09 \\
1992 \\
0.0
\end{tabular} & $\begin{array}{c}5.21 \\
10.11 \\
1988 \\
0.26 \\
1995 \\
3.23 \\
1988 \\
\\
T \\
1988 \\
T \\
1988\end{array}$ & $\begin{array}{c}5.51 \\
10.81 \\
1995 \\
0.00 \\
1989 \\
2.99 \\
1995 \\
\\
17.0 \\
1988 \\
10.0 \\
1988\end{array}$ & $\begin{array}{c}33.30 \\
22.93 \\
\text { JAN } 1995 \\
0.00 \\
\text { JUL } 1990 \\
4.09 \\
\text { OCT } 1992 \\
\\
17.0 \\
\text { DEC } 1988 \\
10.0 \\
\text { DEC } 1988\end{array}$ \\
\hline $\begin{array}{l}\text { WIND } \\
\text { Mean Speed (mph) }\end{array}$ & 9 & 6.7 & 6.7 & 8.1 & 7.4 & 7.7 & 8.1 & 7.4 & 6.7 & 6.3 & 6.5 & 6.1 & 6.6 & 7.0 \\
\hline
\end{tabular}


Appendix C6.

Prevailing Direction

through 1964

Fastest Mile

-Direction(!!)

-Speed(mph)

-Year

Peak Gust

-Direction(!!)

-Speed(mph)

-Date

(a) - Length of Record in Years, although individual months may be missing.

$0{ }^{*}$ or * - The value is between 0.0 and 0.05 .

Normals - Based on the 1961 - 1990 record period.

Extremes - Dates are the most recent occurrence.

Wind Dir.- Numerals show tens of degrees clockwise from true north. "00" indicates calm.

Resultant Directions are given to whole degrees.

\begin{tabular}{|c|c|c|c|c|c|c|c|c|c|c|}
\hline & & & & & & & & & & \\
& & & & & & & & & & \\
17 & 17 & 17 & 02 & 36 & 23 & 35 & 19 & 18 & 17 & 17 \\
53 & 36 & 29 & 38 & 23 & 23 & 29 & 37 & 35 & 60 & 60 \\
1995 & 1993 & 1990 & 1992 & 1995 & 1990 & 1993 & 1992 & 1994 & 1995 & DEC 1995 \\
& & & & & & & & & & \\
$\mathrm{S}$ & $\mathrm{S}$ & $\mathrm{S}$ & $\mathrm{N}$ & $\mathrm{N}$ & $\mathrm{S}$ & & $\mathrm{S}$ & $\mathrm{S}$ & $\mathrm{S}$ & $\mathrm{S}$ \\
74 & 47 & 54 & 60 & 36 & 46 & 44 & 66 & 58 & 85 & 85 \\
1995 & 1995 & 1988 & 1992 & 1995 & 1987 & 1986 & 1989 & 1988 & 1995 & DEC 1995 \\
\hline
\end{tabular}

